AIDO TONSO

Eng. Químico EPUSP, 1987

\title{
ESTUDO DO PROCESSO DESCONTÍNUO ALIMENTADO (FED-BATCH) PARA A SÍNTESE DE GLICOAMILASE POR Aspergillus awamori NRRL 3112
}

Dissertação apresentada à Escola Politécnica da Universidade de São Paulo para a obtenção do título de Mestre em Engenharia Química.

Orientador: Prof. Dr. Willibaldo Schmidell Netto Professor Titular do Departamento de Engenharia Química da E.P.U.S.P.

SÃO PAULO

1994 
A Carmen

A meus pais 


\section{A GR A D E C IMENTOS}

Ao Prof. Willibaldo, orientador, chefe e colega, que insiste em se esforçar para que cresçamos.

Às Professoras Maria Cândida e Beatriz, pelo carinho com que me tratam e estímulo no trabalho.

À Carmen, pela compreensão e apoio agora, mas também pelo carinho destes anos. A cada dia se descobrem mais qualidades e se corrigem as falhas.

A meus pais, que ao longo de todos os anos, sempre me ajudaram e torceram. Sem dúvida, responsáveis diretos por boa parte da minha felicidade.

Ao meu grande amigo Wagner, por tantos risos e carinho, que continue alegrando os outros, onde quer que esteja agora.

A Cynthia, Raquel, Míriam, Gerson e todos colegas do Bloco 20, pela colaboração no trabalho experimental e amizade.

Aos amigos de toda parte, Bloco 21, IPT e sei lá, que acrescentam ao trabalho, amizade.

Aos colegas e funcionários Euclides de Lima e Itsuko Miyamoto, pelo carinho no convivio diário.

Às funcionárias Maria Elisete Monteiro e Terezinha Costa, pelo apoio dado, em especial nos momentos críticos. 


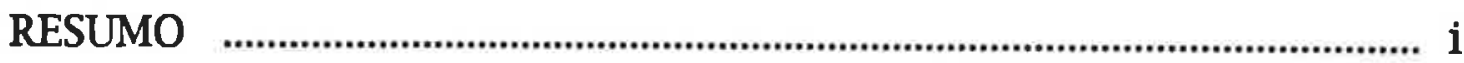

ABSTRACT …….................................................................................... ii

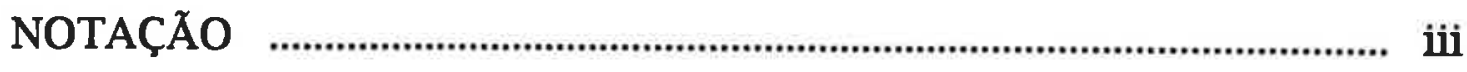

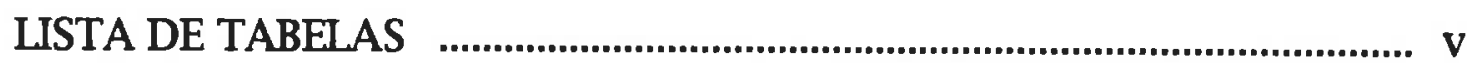

LISTA DE FIGURAS ................................................................................ ix

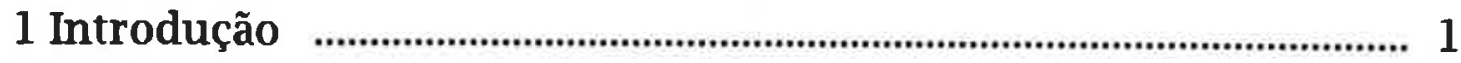

2 Revisão Bibliográfica ............................................................................. 5

2.1 A glicoamilase e suas propriedades ………........................................ 7

2.2 Síntese de enzimas e sua liberação …............................................ 10

2.3 Influência de fatores na síntese de glicoamilase ......................... 20

2.3.1 Microrganismo ................................................................................. 21

2.3.2 Meio de cultura e condições de cultivo ...................................... 22

2.4 Processos de produção de enzimas ................................................ 28

2.4.1 Processo descontínuo alimentado (fed-batch) ........................... 31

3 Materiais e Métodos …........................................................................... 38

3.1 Microrganismo …................................................................................ 38

3.1.1 Linhagem ................................................................................... 38

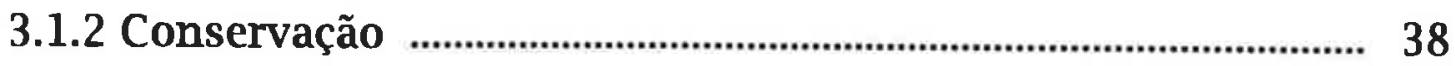

3.1.3 Preparo do Inóculo ...................................................................... 41

3.2 Meio de Cultura ..................................................................................... 44 
3.2.2 Preparo do Meio de Cultura .............................................................. 44

3.3 Ensaios Realizados

3.3.1 Preparo do Fermentador e dos Sistemas de Medida ................. 52

3.3.2 Ensaios Descontínuos Alimentados ......................................... 54

3.4 Controles Analíticos ....................................................................... 56

3.4.1 Determinação da Concentração Celular (X) ............................... 59

3.4.2 Determinação da Concentração de Glicose (G) ........................... 60

3.4.3 Determinação da Concentração de ART - Açúcares Redutores Totais $(\mathrm{S})$................................................................ 60

3.4.4 Determinação da Atividade da Glicoamilase (A) ....................... 62

3.4.5 Método da Glicose-oxidase para a Dosagem de Glicose ......... 65

3.5 Conceitos utilizados na Análise dos Resultados ..........................6.67

3.5.1 Velocidades Específicas ............................................................... 67

3.5.2 Fatores de Conversão e Produtividades ...................................... 69

4 Resultados e Discussão .......................................................................... 72

4.1 Considerações Preliminares ………….............................................. 73

4.1.1 Escalas dos Gráficos .................................................................. 73

4.1.2 Volume de Reação .......................................................................... 74

4.2 Descrição dos Resultados de um Ensaio Descontínuo Típico e sua Variabilidade .............................................................. 78

4.2.1 Ensaios a $S_{0}$ de $20 \mathrm{~g} /$ : B21 a B24 .............................................. 78 
4.2.2 Ensaios a $S_{0}$ de 40 g/: B41 e B42

4.2.3 Velocidades Específicas

4.2.4 Reprodutibilidade dos Resultados: Aspectos Gerais 91

4.2.5 Estabilidade da Cepa Produtora 93

4.2.6 Preparo do Xarope de Farinha de Mandioca e do Meio de Cultura 97

4.3 Ensaios Descontínuos Alimentados a $S_{0}$ de $20 \mathrm{~g} / 1$ 100

4.3.1 Ensaios F21, F22, F23 e F24 100

4.3.2 Ensaios F2H e F2I 111

4.4 Ensaios Descontínuos Alimentados a $S_{0}$ de $40 \mathrm{~g} / \mathrm{l}$ 119

4.5 Discussão Final 129

4.5.1 Velocidades Específicas Máximas de Crescimento 133

5 Conclusões 142

A Apêndices

A-1 Resultados Experimentais 


\section{R E S U M O}

Com o objetivo de estudar diferenças de processo de cultivo e a influência de mecanismos de controle na síntese de glicoamilase, realizaram-se ensaios descontínuos e descontínuos alimentados com Aspergillus awamori NRRL 3112.

EUtilizou-se um meio de cultivo à base de farinha de mandioca, suplementado com nutrientes, em fermentador agitado (700rpm) e aerado (10 litros de $\mathrm{ar} / \mathrm{min}$ ), com volume de reação de 10 litros praticamente constante, fração de inóculo de $10 \%$ em volume, $\mathrm{pH} 4,0$ e temperatura de $35^{\circ} \mathrm{C}$.

Foram realizados ensaios com concentração total de açúcares de $20 \mathrm{~g} / 1$ e $40 \mathrm{~g} / \mathrm{l}$, tanto descontínuos como descontínuos alimentados. Nestes variou-se a vazão mássica de alimentação (fs), o instante de início de alimentação e a condição do xarope de farinha (previamente hidrolisado ou não).

Repetições dos ensaios descontínuos indicaram variabilidade de resultados elevada.

Não se observou expressivas mudanças no crescimento microbiano, a não ser pelo aumento na velocidade específica nos ensaios descontínuos alimentados a $20 \mathrm{~g} / \mathrm{l}$.

A síntese de glicoamilase foi sensivelmente aumentada nos ensaios descontínuos alimentados a $20 \mathrm{~g} / 1$ (produtividade dobrada). A $40 \mathrm{~g} / \mathrm{l}$, obteve-se produtividade $26 \%$ superior.

Os melhores resultados foram obtidos com fs $=17,1$ gART/h a $\mathrm{S}_{\mathrm{o}}=20 \mathrm{~g} / \mathrm{h}$ e fs=32,2 gART/h a $40 \mathrm{~g} / \mathrm{l}$, e obteve-se o pior no ensaio em que se alimentou desde $o$ início de cultivo.

A $S_{0}=20 \mathrm{~g} / 1$ a repressão se apresenta como principal mecanismo de controle de síntese de glicoamilase, não ocorrendo a mesma a $40 \mathrm{~g} / \mathrm{\Lambda}$, ensaios nos quais a indução tornou-se muito relevante. 


\section{A B S T R A C T}

In order to study different processes and the influence of control mechanism on glucoamylase synthesis, several batch and fed-batch runs were made with Aspergillus awamori NRRL 3112.

A medium containing cassava flour and nutrients were used in a 10 liters stirred and aerated tank, at $\mathrm{pH} 4,0$ and temperature $35^{\circ} \mathrm{C}$.

The batch and fed-batch runs used 20 and $40 \mathrm{~g}$ of total reducing sugars (TRS) per liter. In the fed-batch runs, the carbon source feed rate (fs), the feeding start time, and whether the syrup were pre-hydrolyzed or not were varied.

Repeated batch runs showed significant variability.

Notable changes in cell growth were not observed, unless by the increase of the specific growth rate in the 20 gTRS/ $/$ fed-batch runs.

The enzyme productivity doubled in the lower sugar concentration fed-batch runs, but increased just $26 \%$ in the runs with $40 \mathrm{~g} / \mathrm{l}$ of TRS.

The best results were achieved at $20 \mathrm{~g} / \mathrm{l}$ with carbon source feed rate $=17,1 \mathrm{gTRS} / \mathrm{h}$ and $\mathrm{fs}=32,2 \mathrm{gTRS} / \mathrm{h}$ at $40 \mathrm{~g} / \mathrm{l}$. The worst was noted when the feeding started at the beginning of the run.

At 20 gTRS/1, repression showed as the main mechanism control in order to synthesize glucoamylase. On the other hand induction became the relevant factor when $40 \mathrm{gTRS} / 1$ were offered to microorganism. 


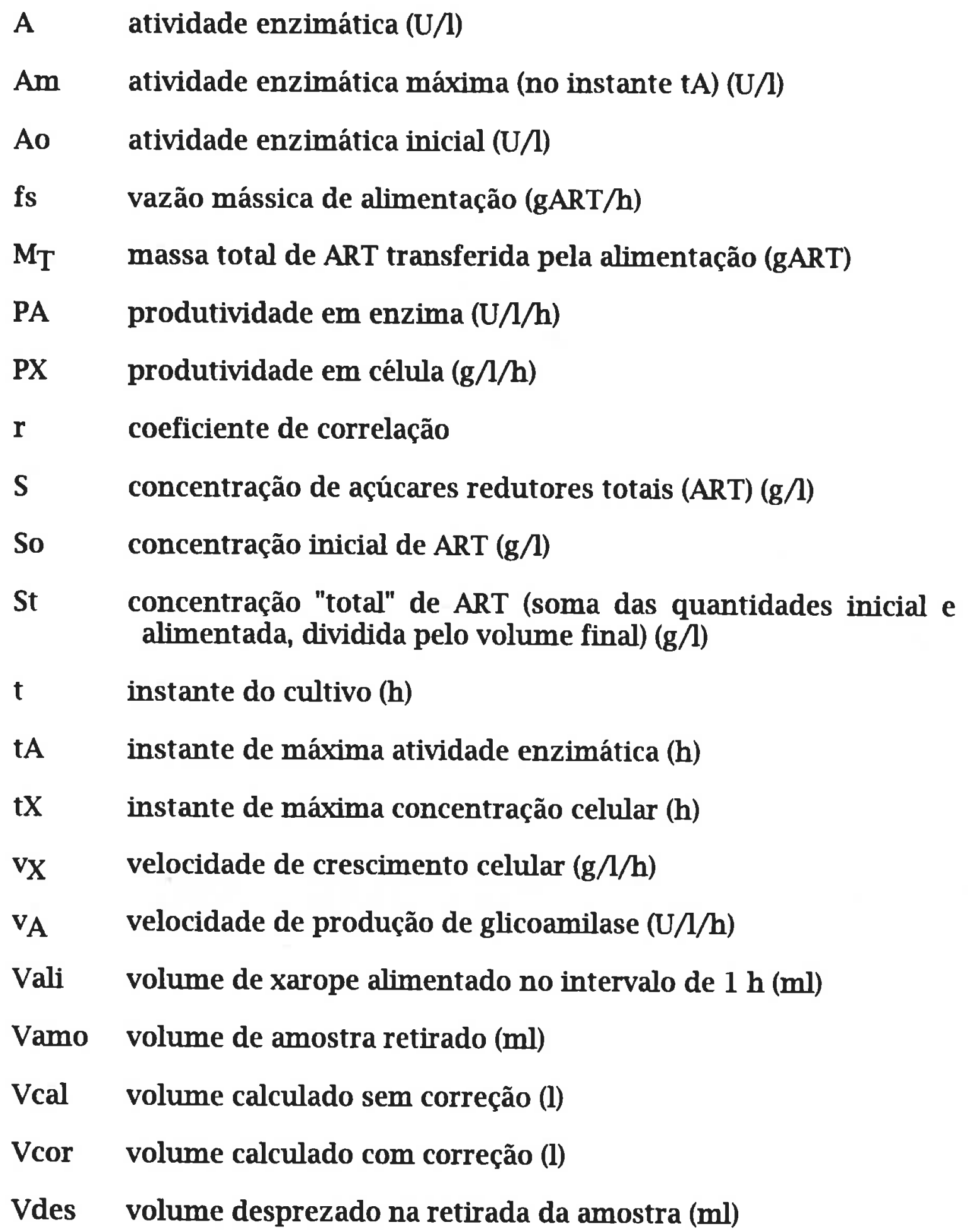


$\mathrm{VHCl}$ volume adicionado de solução de ácido clorídrico em $1 \mathrm{~h}(\mathrm{ml})$

VNaOH volume adicionado de solução de hidróxido de sódio em $1 \mathrm{~h}$ (ml)

$\mathrm{V}_{\mathrm{r}} \quad$ volume inicial de reação (l)

V'r volume final de reação (l)

X concentração celular $(g / 1)$

Xm concentração celular máxima (no instante $\mathrm{tX})(\mathrm{g} / \mathrm{l})$

Xo concentração celular inicial $(g / l)$

YA/S fator de conversão substrato a enzima (U/g)

YX/S fator de conversão substrato a células $(g / g)$

$\Delta \theta \quad$ tempo de alimentação (h)

$\theta_{\mathrm{f}} \quad$ instante do término da alimentação (h)

$\theta_{0} \quad$ instante do início da alimentação (h)

u velocidade específica de crescimento celular $\left(\mathrm{h}^{-1}\right)$

$\mu_{m a ́ x} \quad$ velocidade específica máxima de crescimento celular $\left(h^{-1}\right)$

$\mu \mathrm{A}$ velocidade específica de produção de enzima $(\mathrm{U} / \mathrm{g} / \mathrm{h})$

$\mu \mathrm{A}_{\text {máx }}$ velocidade específica máxima de produção de enzima (U/g/h) 


\section{LISTA DE TABELAS}

Tabela 1.1 Produção e Vendas mundiais de enzimas microbianas, em 1980

Tabela 2.1 Resultados obtidos por Facciotti (1986) para $S_{0}=20$ e $40 \mathrm{~g} / 1$

Tabela 3.1 Descrição dos Ensaios Realizados 49

Tabela 3.2 Contemporaneidade dos Ensaios Realizados 50

Tabela 4.1 Volume calculado sem correção (Vcal), calculado com correção (Vcor), desprezado na retirada de amostra (Vdes), de amostra (Vamo), alimentado no intervalo de 1 hora (Vali), adicionado de hidróxido de sódio (VNaOH) ou ácido clorídrico ( $\mathrm{VHCl}$ ) para manutenção do $\mathrm{pH}$ a cada hora de cultivo no ensaio F21

Tabela 4.2 Grandezas usadas no cálculo de fatores de conversão e produtividades para os ensaios B21, B22, B23 e B24

Tabela 4.3 Grandezas calculadas: fatores de conversão e produtividades para os ensaios B21, B22, B23 e B24

Tabela 4.4 Idem à Tabela 4.2 para os ensaios B41 e B42 86

Tabela 4.5 Idem à Tabela 4.3 para os ensaios B41 e B42 86

Tabela 4.6 Comparação de resultados entre ensaios anteriores e deste trabalho (batch, $S_{0}=20 \mathrm{~g} / \mathrm{l}$ )

Tabela 4.7 Resultados típicos de ensaios a $S_{0}=20 \mathrm{~g} / 1$ na Fase Estacionária

Tabela 4.8 Idem à Tabela 4.2 para os ensaios F21, F22, F23 e F24 
Tabela 4.9 Idem à Tabela 4.3 para os ensaios F21, F22, F23 e F24

Tabela 4.10 Idem à Tabela 4.2 para os ensaios F2H e F2I

Tabela 4.11 Idem à Tabela 4.3 para os ensaios F2H e F2I

Tabela 4.12 Idem à Tabela 4.2 para os ensaios F41, F42, F43 e F4H

Tabela 4.13 Idem à Tabela 4.3 para os ensaios F41, F42, F43 e F4H

Tabela 4.14 Idem à Tabela 4.2 para os diversos ensaios

Tabela 4.15 Idem à Tabela 4.3 para os diversos ensaios

Tabela 4.16 Fase exponencial de crescimento celular dos ensaios realizados

Tabela A.1 Concentração de ART (S), de glicose (G), de células (X) e atividade enzimática (A) em função do tempo para o ensaio B21 ( $1^{\circ}$ batch, $\left.20 \mathrm{~g} / 1\right)$

Tabela A.2 Valores de concentração celular (X) e atividade enzimática (A) considerados para o cálculo das velocidades específicas de crescimento $(\mu)$ e produção de enzima $\left(\mu_{A}\right)$ em função do tempo para o ensaio B21 (10 batch, 20g/1)

Tabela A.3 Idem à Tabela A-1 para o ensaio B22 A-3

Tabela A.4 Idem à Tabela A-2 para o ensaio B22 A-4

Tabela A.5 Idem à Tabela A-1 para o ensaio B23 A-5

Tabela A.6 Idem à Tabela A-2 para o ensaio B23 A-6

Tabela A.7 Idem à Tabela A-1 para o ensaio B24 A-7 
Tabela A.8 Idem à Tabela A-2 para o ensaio B24 A-8

Tabela A.9 Idem à Tabela A-1 para o ensaio B41 A-9

Tabela A.10 Idem à Tabela A-2 para o ensaio B41 A-10

Tabela A.11 Idem à Tabela A-1 para o ensaio B42 A-11

Tabela A.12 Idem à Tabela A-2 para o ensaio B42 A-12

Tabela A.13 Idem à Tabela A-1 para o ensaio F21 A-13

Tabela A.14 Idem à Tabela A-2 para o ensaio F21 A-14

Tabela A.15 Idem à Tabela A-1 para o ensaio F22 A-15

Tabela A.16 Idem à Tabela A-2 para o ensaio F22 A-16

Tabela A.17 Idem à Tabela A-1 para o ensaio F23 A-17

Tabela A.18 Idem à Tabela A-2 para o ensaio F23 A-18

Tabela A.19 Idem à Tabela A-1 para o ensaio F24 A-19

Tabela A.20 Idem à Tabela A-2 para o ensaio F24 A-20

Tabela A.21 Idem à Tabela A-1 para o ensaio F2H A-21

Tabela A.22 Idem à Tabela A-2 para o ensaio F2H A-22

Tabela A.23 Idem à Tabela A-1 para o ensaio F2I A-23

Tabela A.24 Idem à Tabela A-2 para o ensaio F2I A-24

Tabela A.25 Idem à Tabela A-1 para o ensaio F41 A-25

Tabela A.26 Idem à Tabela A-2 para o ensaio F41 A-26

Tabela A.27 Idem à Tabela A-1 para o ensaio F42 A-27

Tabela A.28 Idem à Tabela A-2 para o ensaio F42 A-28 
Tabela A.29 Idem à Tabela A-1 para o ensaio F43

Tabela A.30 Idem à Tabela A-2 para o ensaio F43 A-30

Tabela A.31 Idem à Tabela A-1 para o ensaio F4H A-31

Tabela A.32 Idem à Tabela A-2 para o ensaio F4H A-32 


\section{LISTA DE FIGURAS}

Figura 2.1 Modelo proposto por Jacob e Monod (1961) para a síntese de uma enzima indutiva

Figura 2.2 Representação esquemática da hipótese do sinal para a liberação de uma proteína (Priest, 1983)

Figura 3.1 Esquema do tratamento analítico das amostras dos ensaios de cultivo de Aspergillus awamori NRRL 3112 58

Figura 4.1 Volume de reação calculado sem (Vcal) e com (Vcor) correção ao longo do tempo de cultivo no ensaio F21 (fed-batch; $S_{0}=20 \mathrm{~g} / \mathrm{l} ; \mathrm{fs}=13,3 \mathrm{gART} / \mathrm{h}$ ) 76

Figura 4.2 Resultados obtidos no ensaio B21 ( $1^{\circ}$ batch, $\left.20 \mathrm{~g} / \mathrm{l}\right)$ A) Concentração de ART (S) (*), glicose $(\mathrm{G})(+)$, células $(\mathrm{X})$ $(X)$ e atividade enzimática (A) ( $(\square)$ B) Velocidades especificas de crescimento $(\mu)(----)$ e produção de enzima ( $\mathrm{AA})(--)$

Figura 4.3 Idem à Figura 4.2 para o ensaio B22 $\left(2^{\circ}\right.$ batch, $20 \mathrm{~g} / \mathrm{l})$

Figura 4.4 Idem à Figura 4.2 para o ensaio B23 ( $3^{\circ}$ batch, $20 \mathrm{~g} / \mathrm{l})$

Figura 4.5 Idem à Figura 4.2 para o ensaio B24 $\left(4^{\circ}\right.$ batch, $20 \mathrm{~g} / \mathrm{l})$

Figura 4.6 Idem à Figura 4.2 para o ensaio B41 ( $\left(^{\circ}\right.$ batch, $40 \mathrm{~g} / \mathrm{l})$

Figura 4.7 Idem à Figura 4.2 para o ensaio B42 $\left(2^{\circ}\right.$ batch, $40 \mathrm{~g} / \mathrm{l})$

Figura 4.8 Comparação de resultados entre ensaios anteriores e deste trabalho (batch, $S_{0}=20 \mathrm{~g} / 1$ ) 
Figura 4.9 Idem à Figura 4.2 para o ensaio F21 ................................ 101

Figura 4.10 Idem à Figura 4.2 para o ensaio F22 …........................... 102

Figura 4.11 Idem à Figura 4.2 para o ensaio F23 .............................. 103

Figura 4.12 Idem à Figura 4.2 para o ensaio F24 ............................... 104

Figura 4.13 Idem à Figura 4.2 para o ensaio F2H ............................. 112

Figura 4.14 Idem à Figura 4.2 para o ensaio F2I ................................. 115

Figura 4.15 Idem à Figura 4.2 para o ensaio F41 ................................ 122

Figura 4.16 Idem à Figura 4.2 para o ensaio F43 .............................. 123

Figura 4.17 Idem à Figura 4.2 para o ensaio F42 .............................. 125

Figura 4.18 Idem à Figura 4.2 para o ensaio F4H (fed-batch, $40 \mathrm{~g} /$, fs=21,1 gART/h, xarope hidrolisado) ........ 126

Figura 4.19 Concentração celular (X) em função do tempo, em gráfico mono-log, para os ensaio B21, B22, B23 e B24

Figura 4.20 Idem à Figura 4.19 para os ensaio F21, F22, F23 e F24

Figura 4.21 Idem à Figura 4.19 para os ensaio F2H, F2I, B41 e B42

Figura 4.22 Idem à Figura 4.19 para os ensaio F41, F42, F43 e $\mathrm{F} 4 \mathrm{H}$ 


\section{INTRODUÇÃ O}

A glicoamilase, ou amiloglicosidase, é uma hidrolase amplamente utilizada na indústria e uma das enzimas mais produzidas em todo o mundo. Trata-se de uma exoenzima que age sobre as ligações $\alpha$-1-4 e $\alpha$ 1-6 da molécula de amido, transformando-a em glicose.

Em termos de produção, a glicoamilase ocupa o segundo lugar no cenário mundial, somente superada por protease bacteriana, segundo dados do ano de 1980 (Eveleigh, 1981), conforme se observa na Tabela 1.1.

Tabela 1.1 Produção e Vendas mundiais de enzimas microbianas, em 1980 (Eveleigh, 1981).

\begin{tabular}{|lcc|}
\hline Enzima & Produção & Vendas \\
& (toneladas/ano) & (US\$ milhões/ano) \\
Protease bacteriana & 530 & 66 \\
Glicoamilase & 350 & 36 \\
a-amilase & 320 & 12 \\
Glicose-isomerase & 70 & 56 \\
Renina & 26 & 64 \\
\hline
\end{tabular}

Em relação ao mercado mundial, estimado em US\$ 520 milhões no ano de 1986 (Magalhães, 1989), o Brasil tem uma participação modesta (1,3\%), em especial comparada ao de países desenvolvidos, visto que EUA, Canadá e França somam 66\% deste mercado. Em uma análise per capita, percebe-se que o Brasil, com $3 \%$ da população mundial, consome apenas $43 \%$ da média mundial por habitante. 
No Brasil, pouco investimento tem sido feito visando a produção de enzimas, o que poderia ser explicado pelo baixo consumo. No entanto, o mercado brasileiro não é desprezível em absoluto, tendo sido basicamente um importador nos últimos anos, a um gasto médio de US\$ 5 milhões por ano em importação de enzimas e preparados enzimáticos.

Entre as enzimas importadas de Janeiro a Outubro de 1986, segundo dados da CACEX (Carteira de Comércio Exterior), figura a glicoamilase em maior quantidade (22 toneladas), seguida pela invertase (7 ton), lactase (4 ton) e pectinase fúngica (1 ton) (IPT, 1987).

A principal utilização da glicoamilase se dá na indústria alimentícia e alcooleira, na obtenção de xaropes de glicose a partir de matéria-prima amilácea.

A hidrólise do amido pode ser feita por via enzimática ou via ácida. Os estudos comparativos entre esses dois processos (IPT, 1987) têm apresentado vantagem para a hidrólise enzimática, resultando em maior rendimento e especificidade.

No Brasil, a produção de glicoamilase é relativamente pequena, basicamente devido à baixa produção de etanol a partir de matériasprimas amiláceas e alta produção de sacarose.

No Laboratório de Engenharia Bioquímica da Escola Politécnica da Universidade de São Paulo, tem sido estudada há cerca de 15 anos a produção de glicoamilase, tendo sido tomada como estudo de caso tanto por sua utilidade potencial no mercado brasileiro, como por representar um interessante modelo de síntese de metabólito microbiano. Nesse sentido, cabe ressaltar que as proteínas são das mais 
importantes constituintes celulares e, entre elas, as enzimas se destacam por sua capacidade catalítica, em especial as hidrolases (como a glicoamilase), responsáveis pelo preparo do substrato para a futura assimilação pela célula.

Sabe-se que a síntese da glicoamilase é sujeita aos fenômenos de indução e repressão catabólica e o estudo e controle desses fenômenos leva a uma significativa melhoria do processo. Nessa direção, vários trabalhos foram desenvolvidos e recentemente tais resultados foram reunidos de forma resumida em artigos publicados na revista International Industrial Biotechnology (Schmidell e Facciotti, 1987 e Schmidell et al., 1989), com o objetivo de se mostrar a evolução em relação ao tempo, da atividade enzimática da glicoamilase obtida no caldo fermentado e produtividade em enzima. Assim, de atividades enzimáticas máximas de cerca de $40 \mathrm{U} / \mathrm{h}$ nos primeiros ensaios, passouse a valores de até $7000 \mathrm{U} / \mathrm{l}$, nos cultivos mais recentes, indo a produtividade de 10 até $60 \mathrm{U} / \mathrm{h} / \mathrm{h}$, ilustrando a sensibilidade do sistema ao desenvolvimento de processo.

Em relação especificamente ao processo fermentativo utilizado, vários trabalhos foram desenvolvidos em processo descontínuo, porém também os processos contínuo e semi-contínuo foram estudados.

Neste quadro, tornou-se interessante avaliar o processo descontínuo alimentado, como forma de se apresentar substrato ao microrganismo ao longo do ensaio, de modo a se reduzir o efeito repressivo, mantendo-se contudo o efeito indutivo. Tem-se então no grupo de Engenharia Bioquímica da EPUSP, 3 trabalhos que objetivam o estudo do processo descontínuo alimentado. 
No primeiro, Kilikian (1989) levantou uma série de dados iniciais para o desenvolvimento do processo, tendo concluído basicamente que o processo se apresenta como excelente forma de se melhorar a produção de glicoamilase.

Posteriormente, iniciou-se este trabalho visando levantar mais dados do processo ainda com baixos valores de concentração total de açúcares redutores totais (St), em diferentes condições de alimentação, conforme será visto adiante.

Mais recentemente foi realizado o estudo do processo descontínuo alimentado por Lessmann (1993), trabalhando com maiores valores de St.

Dessa forma, o presente trabalho se inclui em um aprendizado profundo de um processo por um grupo de pesquisa consolidado, objetivando em particular adicionar conhecimento do processo descontínuo alimentado na síntese de glicoamilase por Aspergillus awamori. 


\section{REVIS ÃO BIBLIOGRÁF ICA}

O cultivo de microrganismos para a produção de enzimas hidrolíticas, como a glicoamilase, era empregado no oriente desde períodos pré-históricos, para o preparo de alimentos e bebidas fermentadas. Os primeiros registros de produção em escala comercial no ocidente são de 1894, com a produção de um complexo de enzimas amilolíticas e proteolíticas, denominado takadiastase, obtido através de um cultivo de Aspergillus oryzae (Aunstrup, 1979).

O primeiro grande impulso, no entanto, se deu no início deste século (1915) com a produção de proteases bacterianas como ingrediente de detergentes. Nas décadas seguintes, o progresso foi menor que o esperado, devido basicamente a deficiências tecnológicas, no que se refere a técnicas de assepsia e processos de recuperação das enzimas produzidas (downstream processing).

Na década de 60, a glicoamilase e outras amilases passaram a ser utilizadas na hidrólise enzimática de amido para a produção de xaropes de glicose.

Atualmente, constam da lista da Comissão Internacional de Enzimas (EC) cerca de 2000 diferentes enzimas. Destas, somente cerca de 50 tem aplicação industrial e são utilizadas em quantidades apreciáveis, devido a limitações legais (em especial na indústria alimentícia) e altos custos ainda envolvidos, particularmente na recuperação das enzimas intracelulares (Magalhães, 1989). Entre essas, destaca-se a glicoamilase como uma das produzidas em maior quantidade. 
Nos últimos anos, muitos estudos têm sido feitos para reduzir os custos de produção e utilização de enzimas, em especial: busca de melhores cepas produtoras (por mutação e seleção e também por engenharia genética), imobilização de enzimas ou microrganismos produtores (Kuek, 1991) e produção de enzimas termoestáveis (Wasserman, 1984). Paralelamente, grande avanço se obteve na compreensão dos mecanismos de síntese enzimática e de excreção da enzima sintetizada, pois a maioria das enzimas comerciais são extracelulares. Estes aspectos relacionados com a síntese de glicoamilase serão abordados a seguir. 


\subsection{A Glicoamilase e suas propriedades}

A glicoamilase, ou $\alpha$-D-(1,4) glican-glicohidrolase (EC 3.2.1.3), é a enzima que converte amido em glicose, agindo sobre as ligações $\alpha-1-4$ e a-1-6 deste polissacarídeo. E utilizada na produção de xaropes de glicose a partir de fontes amiláceas, basicamente na indústria alimentícia, mas também na produção de etanol.

$\mathrm{Na}$ literatura, encontram-se diversas referências sobre microrganismos produtores de glicoamilase (Attia e Ali, 1974, Ensley et al., 1975, Fogarty, 1983, Gracheva et al., 1973, Sinkar e Lewis, 1982). No entanto, apresentam interesse industrial somente aqueles dos gêneros Aspergillus, Endomyces e Rhizopus (Aunstrup, 1979).

Dentre as espécies de Aspergillus, destacam-se o Aspergillus niger e Aspergillus awamori (Crueger e Crueger, 1984, Kvesitadze et al., 1981, Smiley et al., 1964).

A glicoamilase de Aspergillus niger é constituída na realidade por duas isoenzimas: glicoamilase I e glicoamilase II (Lineback e Aira, 1972, Pazur et al., 1971, Pazur et al., 1980, Smiley et al., 1971), enquanto que com relação ao Aspergillus awamori existem indicações da presença de até três isoenzimas, designadas por I, I' e II (Crueger e Crueger, 1984 e Hayashida et al., 1982). Menciona-se inclusive, que a glicoamilase I é a fonte das glicoamilases I' e II, pois estas últimas foram obtidas "in vitro" por modificações enzimáticas nas moléculas da glicoamilase I, sendo que a proporção entre elas pode variar em função das condições de cultivo empregadas. 
Com relação a glicoamilase produzida por Aspergillus awamori, Hayashida et al. (1982) afirmam que a glicoamilase I é ativa sobre o amido não submetido a cozimento, enquanto que a glicoamilase I' e II não o são. Ressaltam também que a glicoamilase I pode perder a atividade sobre o amido não cozido, quando perde um glicopeptídeo por ação de proteases, passando assim a ser denominada glicoamilase I'.

A glicoamilase é capaz de degradar a molécula de amido em moléculas de glicose, com rendimento bastante próximo do estequiométrico. Nesse processo, a enzima age sobre as ligações $\alpha-1-4 \mathrm{e}$ $\alpha-1-6$ com velocidades de rompimento bastante diferentes: sobre $\alpha-1-4$ cerca de 40 vezes mais rápido que sobre $\alpha-1-6$ (Lineback et al., 1969, Kulp, 1975 e Di Luccio e Kirwan, 1984). Por este motivo, alguns autores como Crueger e Crueger (1984), não consideram a ação da glicoamilase sobre as ligações $\alpha-1-6$. Há também, para garantir a hidrólise completa destas ligações, a proposta de adição de pululanase juntamente a glicoamilase (Ram e Venkatasubramanian, 1982 e Schafhauser e Story, 1993). Esses últimos obtiveram com a adição dessa enzima aumentos na conversão do amido de até 100\%.

Segundo Aunstrup (1979), durante a produção de glicoamilase também são produzidas a $\alpha$-amilase e a transglicosidase, porém em menor proporção. A $\alpha$-amilase é denaturada rapidamente, se o pH do meio de cultura for mantido abaixo de 4,5. De qualquer forma, pequenas quantidades desta enzima não interferem na qualidade do produto final. $O$ mesmo não pode ser dito a respeito da transglicosidase. Sua presença é indesejável, pois essa enzima catalisa a sintese de oligossacarídeos, tais como a panose e isomaltose, podendo 
reduzir significativamente o rendimento final em glicose (Fogarty, 1983). Essa deve, portanto, ser removida no processo de recuperação da glicoamilase. Entretanto, existem microrganismos que produzem quantidades insignificantes de transglicosidase, destacando-se entre eles, o Aspergillus awamori NRRL 3112, utilizado no presente trabalho.

Com relação às melhores condições de ação da enzima produzida por Aspergillus, verifica-se, de maneira geral, que o $\mathrm{pH}$ ótimo situa-se entre 4,5 e 5,0 (Fogarty, 1983 e Lineback et al., 1969), enquanto que a temperatura ótima é $60^{\circ} \mathrm{C}$ (Aunstrup, 1979 e Fogarty, 1983). As isoenzimas comportam-se semelhantemente quanto a $\mathrm{pH}$ e temperatura. 


\subsection{Sintese de enzimas e sua liberação}

Numa célula microbiana, existe um número muito elevado de diferentes enzimas, que catalisam as diversas reações metabólicas envolvidas no processo de crescimento do microrganismo. Entretanto, os metabólitos não são produzidos em excesso, a não ser nos casos em que as células tenham sofrido alguma alteração genética. Para controle da produção dessas várias enzimas, existem vários mecanismos de regulação metabólica.

As enzimas constitutivas são produzidas pelas células, independentemente do substrato empregado. Por outro lado, são chamadas enzimas indutivas (ou de indução), aquelas que apresentam sintese sensivelmente aumentada quando da presença de um indutor no meio de cultura, geralmente o próprio substrato da enzima. Isso não significa que nenhuma síntese ocorre na ausência de substrato, mas que a velocidade de síntese é consideravelmente aumentada na presença do indutor, que pode ser seu substrato ou um análogo.

Entre os melhores exemplos de enzimas indutivas, tem-se aquelas responsáveis pela hidrólise de polissacarídeos (como as amilases, celulases, etc). Apesar da síntese ser ampliada fortemente na presença do substrato, parte da produção deve ocorrer sempre, de modo a permitir uma hidrólise parcial, gerando compostos de massa molecular pequena o suficiente para atravessar a membrana celular e ativar o mecanismo de indução (Priest, 1983). 


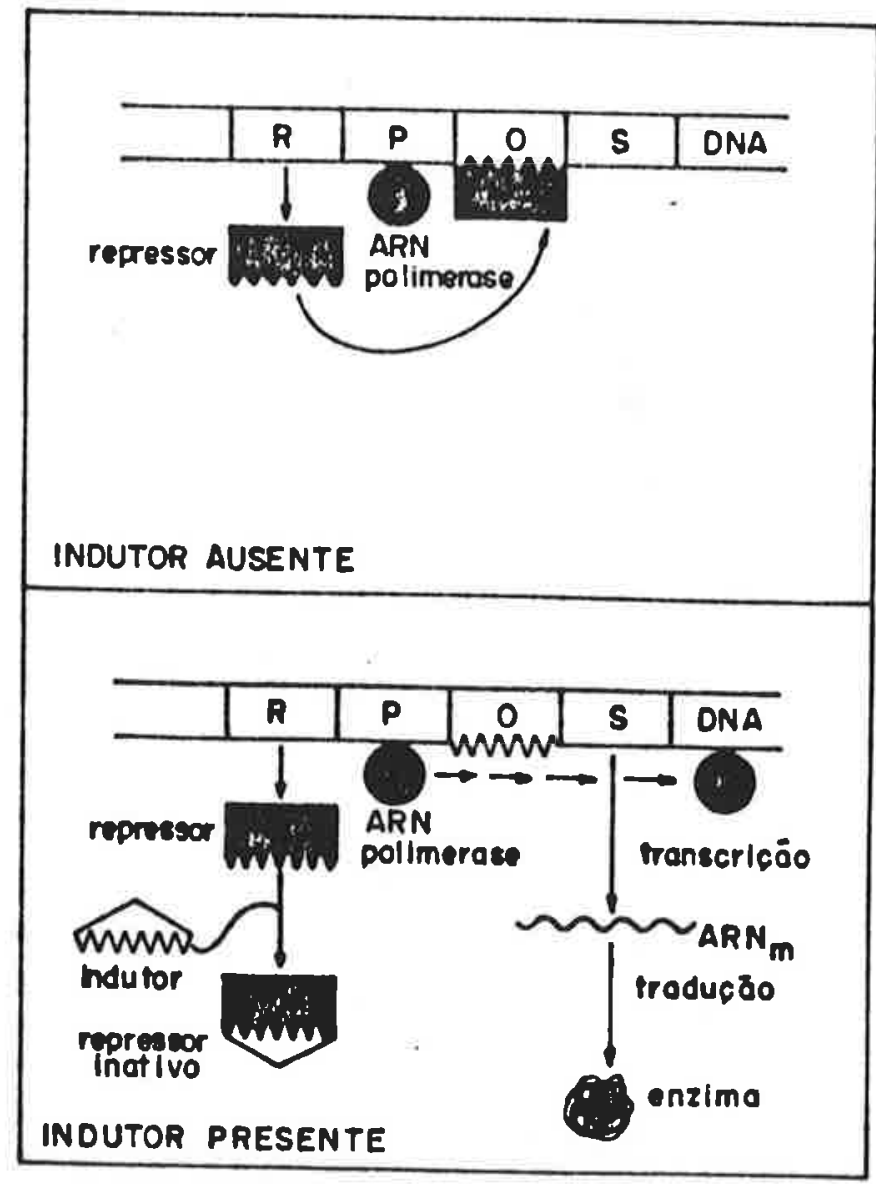

Figura 2.1 Modelo proposto por Jacob e Monod (1961) para a síntese de uma enzima indutiva. 
Alguns desses mecanismos de regulação metabólica são apresentados por Wang et al. (1979) e Brock (1979), em especial o modelo proposto por Jacob e Monod (1961). Segundo este modelo, esquematizado na figura 2.1, a síntese de uma dada enzima indutiva depende de pelo menos 4 genes em uma dada região da molécula de ácido desoxiribonucleico (DNA). O gene chamado regulador (R) codifica a produção de uma proteína repressora (repressor), a qual pode se ligar ao gene operador $(0)$, que por sua vez, regula a ação do gene estrutural (S). Finalmente, a enzima responsável pela síntese do ácido ribonucleico mensageiro (RNAm), chamada de RNA polimerase, inicia a transcrição ligando-se ao gene promotor (P). Caso o gene $O$ esteja bloqueado, a RNA polimerase não poderá prosseguir e, portanto, não ocorrerá a síntese de RNAm. Consequentemente, não haverá a síntese da enzima em questão. Caso o indutor esteja presente, a proteína repressora se combinará com ele, e não mais se ligará ao gene 0 , permitindo a transcrição do RNAm.

Ainda que o modelo de Jacob \& Monod seja a base de outros modelos propostos posteriormente para a síntese de enzimas, ele não é perfeitamente válido para organismos eucariotos, que apresentam membrana nuclear (núcleo diferenciado), de forma que a substância indutora não se encontra nas vizinhanças da molécula de DNA.

As enzimas que degradam polímeros têm normalmente sua síntese regulada pela indução, como já visto, e pela repressão catabólica.

O fenômeno de repressão catabólica, também chamado de "efeito glicose", ocorre quando há no meio mais de um substrato que o microrganismo pode consumir (Wang et al., 1979 e Bailey e Ollis, 1986). 
Nesse caso, são produzidas as enzimas necessárias para consumir o substrato mais facilmente utilizável pela célula e, só após o término deste, o microrganismo sintetiza enzimas para hidrolisar o substrato secundário. Repressão catabólica é definida como o decréscimo na velocidade de síntese de uma dada enzima devido à presença no meio de um substrato imediatamente utilizável, que não necessita daquela enzima para ser consumido. Como exemplo, tem-se a repressão à síntese de $\beta$-galactosidase no cultivo de Escherichia coli em glicose.

Apesar da repressão catabólica ser historicamente conhecida como "efeito glicose", convém lembrar que outras fontes de carbono podem ser tão ou mais repressoras que a glicose e que, em alguns organismos, esta é a fonte de carbono que sofre repressão, como é o caso de Pseudomonas aeruginosa, onde a presença de citrato reprime enzimas do catabolismo de glicose.

Tanto quanto a indução, o mecanismo da repressão catabólica em procariotos também pode ser explicado com base na figura 2.1, com algumas alterações. Para que haja a produção de uma proteína, ou enzima, é necessária a síntese do RNA mensageiro correspondente, através da ligação da RNA polimerase na molécula de DNA no gene promotor (P). Nas enzimas reguladas por repressão catabólica, requer-se ainda a ligação prévia de uma proteína ativadora no mesmo gene, que só acontece se essa proteína já estiver associada a uma pequena molécula de monofosfato de adenosina cíclica (AMP cíclica). Esta é sintetizada a partir de trifosfato de adenosina (ATP), reação inibida pela glicose. Assim, na presença de glicose não há síntese de AMP cíclica, de modo que a proteína ativadora e consequentemente a RNA polimerase 
não se ligam ao gene $P$, não havendo a síntese da enzima em questão (Brock, 1979).

No que se refere a organismos eucariotos, o mecanismo da repressão catabólica não está bem esclarecido. Arst e Bailey (1977) indicam não existir evidências do envolvimento da AMP cíclica na repressão catabólica no Aspergillus nidulans, quando se trata do metabolismo do carbono.

Com relação à síntese de glicoamilase, vários trabalhos da literatura mencionam os mecanismos de indução e repressão catabólica mencionados, além da influência da composição do meio de cultura e condições de cultivo empregadas.

Como a glicoamilase atua sobre as ligações glicosídicas $\alpha-1-4$ e $\alpha-1-6$, é de se supor a princípio que sua sintese possa ser induzida por uma grande variedade de moléculas derivadas da glicose, compreendendo desde amido e dextrinas (grandes polímeros) até oligossacarídeos de menor peso molecular, incluindo-se ainda dímeros da glicose, como a maltose (formada por 2 unidades de glicose unidas por uma ligação $\alpha-1-4)$ e a isomaltose (ligação $\alpha-1-6)$ (Barton et al., 1972 e Ensley et al., 1975).

Barton et al. (1972) testaram, em um trabalho clássico neste assunto, uma série de compostos quanto à sua capacidade em induzir a síntese de glicoamilase por Aspergillus niger NRRL 330, através de cultivo em frascos agitados. 0 máximo efeito indutivo foi obtido nos ensaios com maltose e isomaltose como fonte de carbono, porém mesmo nos ensaios em que se utilizou somente glicose houve formação de glicoamilase. Nesse trabalho, é defendida a idéia de que a síntese de 
glicoamilase é realmente induzida por maltose ou isomaltose, e não por polissacarídeos, que aparentemente são muito grandes para penetrar no interior das células do microrganismo e provocar a indução.

Doyle et al. (1991) obtiveram maior atividade enzimática utilizando como fonte de carbono, a maltose, entre várias, na síntese de glicoamilase por Penicillium expansum.

Similarmente, Ramachandran et al. (1979) observaram a síntese de glicoamilase usando quinze diferentes fontes de carbono, incluindo glicose, no cultivo de Aspergillus niger em frascos agitados. O efeito indutivo máximo foi obtido ao empregar dextrina, seguindo-se em ordem decrescente, amido solúvel, maltose, pectina, glicose e celobiose.

Aunstrup (1979) sugere concentrações de amido de até $150 \mathrm{~g} / \mathrm{na}$ busca do efeito indutivo. No entanto, a enzima sintetizada hidrolisa rapidamente o amido, produzindo altas concentrações de glicose, causando repressão catabólica.

Negrão et al. (1981), trabalhando com Dactylium dendroides, indicaram que houve intensa produção de glicoamilase quando se empregou amido solúvel como fonte de carbono, não tendo sido detectada praticamente nenhuma atividade enzimática quando se propôs glicose ou glicerol como substrato.

Em trabalho mais recente, Ali et al. (1990a) afirmam que, entre determinados carboidratos não amiláceos, a glicose foi responsável pela maior indução à síntese de glicoamilase por Aspergillus terreus, e em menor intensidade, celobiose, sorbitol e sacarose. Manose, galactose, sorbose, lactose e celulose, entre outros, mostraram-se grandes repressores. 
Ainda com relação à indução, convém citar o trabalho de Mandels et al. (1962), no qual é estudada a soforose como forte indutor à síntese de celulase por Trichoderma viride QM6a. O trabalho mostra que soforose apresenta poder de indução, na forma (U celulase induzida/mg indutor), 2800 vezes superior à celobiose, considerada normalmente o indutor da celulase. $\mathrm{E}$ ainda, que mesmo crescendo o microrganismo em meio a base de glicose grau p.a., observou-se indução, o que foi posteriormente associado ao fato da glicose apresentar $0,0058 \%$ de soforose como impureza.

Se por um lado, diversos trabalhos mostram-se concordantes com relação à indução e aos substratos indutores da síntese de glicoamilase, por outro lado, observa-se na literatura algumas divergências com relação à repressão catabólica.

Aunstrup (1979) afirma que este fenômeno não ocorre quando se emprega Aspergillus, sem apresentar no entanto dados ou referências. Yokoya e Vitali (1973) mostram que a produção de glicoamilase por Bacillus subtilis em cultivo contínuo é reprimida pela glicose. Na mesma direção, Crueger e Crueger (1984) afirmam que glicose, ácido glutâmico e lactose causam repressão catabólica, sem fornecer dados ou referências. Os resultados obtidos por Attia e Ali (1974), no cultivo de Aspergillus awamori, indicam igualmente baixas produções de glicoamilase quando se emprega como fonte de carbono sacarose, lactose, frutose e galactose.

Deve-se ressaltar portanto, que o assunto é bastante complexo e que a intensidade dos efeitos indutivo e repressivo que regulam a síntese de glicoamilase dependem de grande número de fatores: 
microrganismo utilizado, composição do meio de cultura, concentração inicial da fonte de carbono e até condições de cultivo empregadas.

A liberação de proteínas pelas células, especialmente de enzimas, é também um fenômeno que tem sido bastante estudado. Nesse sentido, podem-se citar as revisões de Ramaley (1979), Priest (1983) e Holland et al. (1986).

Segundo Priest (1983), foram Blobel e Sabatini que propuseram pela primeira vez em 1971, a "hipótese do sinal" para explicar a liberação de proteínas a partir do interior das células, atualmente bem aceita por outros autores. Segundo esta hipótese, uma proteína extracelular tem sua síntese iniciada nas proximidades da membrana citoplasmática através da codificação de uma sequência de aminoácidos, designada por "peptídeo de sinal" (figura 2.2). Esta sequência de aminoácidos se ligaria a uma ou mais proteínas existentes na membrana formando um túnel. Através deste, o restante da cadeia polipeptídica sairia da célula à medida que fosse sendo sintetizada. Na parte exterior da membrana existiria uma protease, chamada peptidase de sinal, que cortaria a sequência de aminoácidos utilizada como sinal, deixando a proteína com a sua estrutura final. 


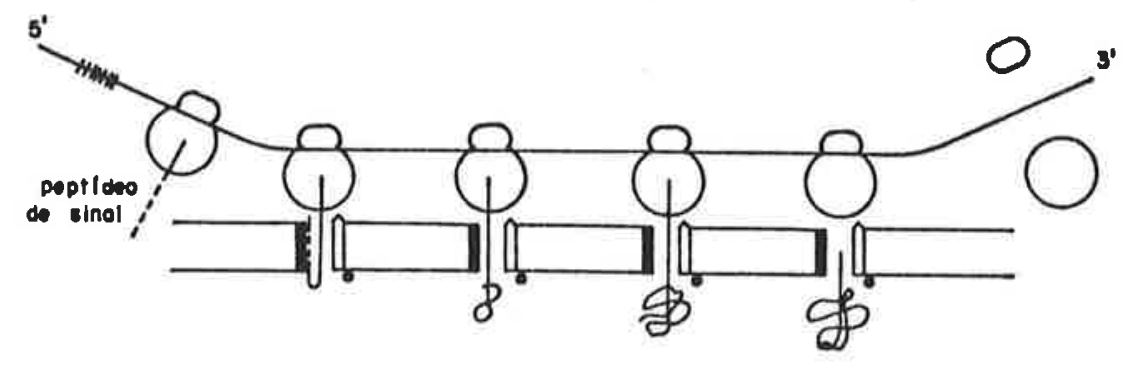

Figura 2.2 Representação esquemática da hipótese do sinal para a liberação de uma proteína (Priest, 1983).

Segundo esse modelo, a proteína estaria sendo sintetizada ao mesmo tempo que expelida para o meio, de modo que a síntese é denominada co-traducional. Por esse motivo, Ramaley (1979) ressalta a importância de se investigar quais fatores influenciam a ação da peptidase de sinal, pois tais fatores devem interferir diretamente no rendimento final de enzimas extracelulares.

Esta hipótese de sinal foi formulada com base em estudos com bactérias, sendo mais complexa quando se trata de células eucarióticas. No entanto, Priest (1983) observou que alguns fungos filamentosos, como Trichoderma viride, não apresentam certas estruturas próprias para a secreção de substâncias (retículo endoplasmático e aparelho de Golgi), o que aproximaria o modelo proposto de determinadas células eucarióticas. 
Para os fungos do gênero Aspergillus, Aguero (1987) aventa a hipótese de que a síntese co-traducional se dê no retículo endoplasmático rugoso, para então ser transportada, em vesículas de secreção, até o ápice das hifas do micélio, onde a enzima sintetizada seria excretada através da parede celular. A glicoamilase permaneceria ligada à parede da célula ou liberada para o meio circundante. Alterações na parede celular provocadas por um agente tensoativo poderiam, dessa forma, influenciar a liberação de proteínas para o meio exterior (Reese e Maguirre, 1969).

Com relação a glicoamilase, Macedo (1982), trabalhando em cultivo descontínuo de Aspergillus niger NRRL 337, mostrou que, além da glicoamilase extracelular determinada através da dosagem da atividade enzimática do caldo fermentado, obtinha-se também uma parcela intracelular desta enzima. Indicou também que fração intracelular da enzima total varia muito com o pH do meio de cultura, sendo 30\% em pH 3,0 e 70\% em pH 6,0.

Já com Aspergillus awamori NRRL 3112, Aguero (1987) constatou que o fenômeno de retenção intracelular de enzimas é menos intenso. A pH 5,0, 21\% da enzima total permaneceu retida junto às células, enquanto que a pH 3,0 esta fração manteve-se em cerca de $8 \%$.

Observa-se que de modo geral, particular atenção tem-se dedicado aos mecanismos de liberação das enzimas que permanecem retidas junto às células, assim como aos fatores que influenciam essa liberação. Essas informações mostram-se úteis não apenas para a produção industrial de glicoamilase, mas também na busca de novas cepas produtoras da enzima e melhores condições de cultivo. 


\subsection{Influência de fatores na síntese de glicoamilase}

Como em qualquer processo fermentativo, uma série de fatores são decisivos para se atingir um objetivo, seja o crescimento microbiano, ou a produção de determinada substância do metabolismo celular, ou ainda a degradação de algum substrato indesejável. Entre esses fatores, destacam-se o microrganismo adotado, a composição do meio, incluindo-se o oxigênio dissolvido, as condições de cultivo, como pH e temperatura, e naturalmente a forma de operação do bioreator. Estes aspectos serão abordados nos itens a seguir: 2.3.1, 2.3.2 e 2.4. Sendo objeto de estudo do presente trabalho, o processo descontínuo alimentado (fed-batch), bem como outros processos, serão abordados mais especificamente, em um item a parte (2.4).

É claro que uma série de temas já abordados anteriormente, como os mecanismos de síntese (indução e repressão) e liberação de proteínas, são também fatores que influenciam na síntese de glicoamilase, mas, por clareza, foram apresentados anteriormente. A recuperação da enzima, chamada de "downstream processing", não será abordada, apesar de ser etapa importante na produção industrial. Apenas de ilustração, Ali et al. (1990b), em trabalho sobre a purificação de glicoamilase de Aspergillus terreus, conseguem obter uma solução enzimática 22 vezes mais concentrada em glicoamilase que o caldo de cultura filtrado, através de técnicas de diálise e cromatografia de troca aniônica e de afinidade. 


\subsubsection{Microrganismo}

Conforme já mencionado no item 2.1, há vários microrganismos produtores de glicoamilase, destacando-se as espécies Aspergillus awamori e A.niger, como de interesse industrial (Aunstrup, 1979). Acrescente-se ainda que a glicoamilase de Aspergillus é preferida por sua maior termoestabilidade, além do fato de se encontrar no produto final uma baixa atividade de transglicosidase.

Com base na coleção de culturas do "Northern Regional Research Laboratory", Smiley et al. (1964) realizaram uma seleção de linhagens, testando inúmeras culturas de Aspergillus. Constataram que a linhagem de Aspergillus awamori NRRL 3112 produziu 3 a 4 vezes mais glicoamilase que o Aspergillus niger NRRL 337, inclusive obtendo teor de transglicosidase consideravelmente mais baixo na cepa melhor produtora de glicoamilase.

Semelhantemente, Schmidell et al. (1986) observaram a superioridade da cepa Aspergillus awamori NRRL 3112 (tendo atingido 1030 U/1 de atividade máxima no caldo), efetuando o cultivo descontínuo em fermentador de 10 litros, ao compará-la com Aspergillus niger NRRL 337 (161 U/1), Aspergillus niger NRRL 3122 (638 U/1) e uma outra cultura de Aspergillus awamori AWG/547 (cedida pela Bioferm Pesquisa e Desenvolvimento S.A., 938 U/1).

Pode-se ainda acrescentar o trabalho de Park e Lima (1972), que selecionaram, de um total de trinta, sete linhagens de fungos produtores de glicoamilase, no qual se destacaram o Aspergillus awamori NRRL 3112 e Aspergillus niger NRRL 3122. 
Um outro aspecto relacionando o microrganismo à capacidade produtiva é a morfologia da célula. A produção de penicilina por Penicillium chrysogenum varia significativamente se o fungo cresce como micélio ou "pellet" (Wittler e Schügerl, 1985). Da mesma forma, Stanbury e Whitaker (1984) apresentam em seu livro alguns exemplos da influência da morfologia de um fungo sobre sua performance industrial, destacando-se que é recomendado o crescimento como "pellet" para fermentação cítrica por Aspergillus niger.

Em trabalho recente, Olsvik e Kristiansen (1992) levantam uma série de fatores que influenciam na reologia do caldo de fermentação contínua de Aspergillus niger, indicando o quociente entre o índice de consistência $(\mathrm{K})$ e a concentração celular $(\mathrm{X})$ como um termo que descreve a morfologia da cultura, em dado instante.

\subsubsection{Meio de Cultura e Condiçōes de Cultivo}

Indubitavelmente a composição do meio é um fator decisivo na síntese de glicoamilase por Aspergillus awamori. Alguns aspectos já foram apresentados, quando se discutiu a importância de se induzir as células com polissacarídeos e diminuir a repressão catabólica (item 2.2).

A influência da concentração inicial de polissacarídeos $\left(\mathrm{S}_{0}\right)$ na produção de glicoamilase por Aspergillus awamori NRRL 3112 em fermentador foi estudada por Facciotti (1986) e Kilikian (1989).

Utilizando um meio de cultura a base de xarope de farinha de mandioca em fermentação submersa (10 litros de meio) a pH 4,0, 
Facciotti (1986) variou $S_{0}$ de 20 a $100 \mathrm{~g} / \mathrm{l}$, no intuito de procurar quantificar os efeitos de indução e repressão na síntese da enzima. Observou-se aumento na atividade máxima no caldo a medida em que $\mathrm{S}_{\mathrm{o}}$ aumenta até $80 \mathrm{~g} / \mathrm{l}$, indo de $470 \mathrm{U} / 1$ a $20 \mathrm{~g} / 1$ até $2580 \mathrm{U} / \mathrm{l}$ a $80 \mathrm{~g} / \mathrm{l}$. Com $S_{0}$ ainda maiores, observou-se um decréscimo na Am: 1330 U/ a $100 \mathrm{~g} / \mathrm{l}$. Objetivando comparação com os ensaios descontínuos a $S_{0}$ de 20 e $40 \mathrm{~g} / \mathrm{l}$ do presente trabalho, são apresentados na Tabela 2.1 os resultados obtidos para essas concentrações.

Tabela 2.1 Resultados obtidos por Facciotti (1986) para $S_{0}=20$ e $40 \mathrm{~g} / \mathrm{l}$. (nomenclatura conforme notação, à página iii)

\begin{tabular}{|ccccccc|}
\hline $\mathrm{S}_{\mathbf{0}}$ & $\mathrm{Xm}$ & $\mathrm{Am}$ & $\mathrm{YX} / \mathrm{S}$ & $\mathrm{YA} / \mathrm{S}$ & $\mathrm{PX}$ & $\mathrm{PA}$ \\
$(\mathrm{g} / \mathrm{M})$ & $(\mathrm{g} / \mathrm{l})$ & $(\mathrm{U} / \mathrm{l})$ & $(\mathrm{g} / \mathrm{g})$ & $(\mathrm{U} / \mathrm{h})$ & $(\mathrm{g} / \mathrm{h} / \mathrm{h})$ & $(\mathrm{U} / \mathrm{l} / \mathrm{h})$ \\
21 & 8,1 & 470 & 0,39 & 21,8 & 0,45 & 27,4 \\
38 & 11,6 & 1820 & 0,32 & 57,2 & 0,47 & 64,2 \\
\hline
\end{tabular}

Segundo a autora, é muito difícil se estabelecer uma separação nítida entre os fenômenos de indução e repressão, pois são influenciados por uma série de fatores simultâneos, como a hidrólise de polissacarídeos pela reação enzimática (gerando glicose), o consumo de glicose pelo microrganismo e a concentração inicial de polissacarídeos.

Similarmente, Kilikian (1989) realizou ensaios a $\mathrm{pH} 5,0$, observando que em ensaios descontínuos os resultados em atividade enzimática máxima e produtividade em enzima são bastante superiores que os ensaios a $\mathrm{pH}$ 4,0. Por outro lado, ao comparar ensaios descontínuos alimentados, $\mathrm{Am}$ a $\mathrm{pH} 4,0$ resultou cerca de $12 \%$ superior à $\mathrm{pH} 5,0$. 
Além da fonte de carbono, outros nutrientes podem ser igualmente importantes na composição do meio, em particular a fonte de nitrogênio, conforme foi observado por Barton et al. (1969) e Chiquetto (1990), entre outros. De modo genérico, o emprego de sais de amônio, como $\left(\mathrm{NH}_{4}\right)_{2} \mathrm{HPO}_{4},\left(\mathrm{NH}_{4}\right) \mathrm{H}_{2} \mathrm{PO}_{4}$ e tartarato de amônio, pode conduzir a altos rendimentos em glicoamilase (Ramachandran et al., 1979).

Nas culturas deficientes em nitrogênio, há a produção de proteases ácidas. Shinmyo et al. (1971) observaram numa linhagem de Aspergillus niger que ocorre uma autoindução na produção de proteases pelo microrganismo. Esta autoindução decorre da degradação de proteínas celulares, que passam a atuar como substrato indutor intracelular. Um decaimento nos valores de concentração celular na etapa final dos cultivos descontínuos e descontínuos alimentados pode ser explicado por este fenômeno. Igualmente, a ação das proteases sintetizadas pode degradar as moléculas de glicoamilase.

Barton et al. (1972) também estudaram a influência da adição de sulfato ao meio de cultura. Quantidades crescentes deste micronutriente resultaram em crescimento celular mais intenso, bem como aumento na atividade enzimática, mantendo praticamente constante a atividade específica (atividade enzimática por unidade de massa de células).

Especificamente em relação ao extrato de levedura, Facciotti et al. (1991) demonstraram que este exerce marcante influência na síntese de glicoamilase por Aspergillus awamori NRRL 3112. Realizando ensaios em fermentador com 10 litros de meio de cultura e utilizando apenas 
glicose como fonte de carbono $(20 \mathrm{~g} / \mathrm{l})$, obtiveram atividade enzimática final dobrada (de 320 para $630 \mathrm{U} / 1$ ) quando a concentração inicial de extrato de levedura foi variada de 0,5 a 4,0 g/ . Em ensaios com $40 \mathrm{~g} / \mathrm{l}$ de glicose, a atividade final variou de 470 até $2330 \mathrm{U} /$, frente a variação da concentração inicial de extrato de levedura de 1,0 a $12,0 \mathrm{~g} / \mathrm{l}$. Aparentemente esse nutriente apresenta a capacidade de diminuir o efeito repressivo causado pela glicose.

Chiquetto (1990) estudando diferentes fontes de carbono e nitrogênio na síntese de glicoamilase por Aspergillus awamori NRRL 3112 , mostrou que em fermentação submersa a pH 5,0, a melhor fonte de nitrogênio, dentre quatro testadas, é uréia $\left(\mathrm{NH}_{2} \mathrm{CONH}\right)_{2}$, seguida por hidróxido de amônio $\left(\mathrm{NH}_{4} \mathrm{OH}\right)$. Com relação à fonte de carbono, ensaios com sulfato de amônio apresentaram melhores resultados quando foi usada a farinha de mandioca, obtendo-se atividade enzimática máxima ligeiramente menor que com maltose (781 e $825 \mathrm{U} / 1$ respectivamente), porém com produtividade bastante superior $(26,0 \mathrm{U} / \mathrm{h} / \mathrm{h}$, em comparação a 17,9 U/1/h com maltose). Na presença de glicose obteve-se atividade máxima de $500 \mathrm{U} / 1$ e produtividade em enzima de 10,6 U/1/h e, como pior fonte de carbono, frutose $(51,5 \mathrm{U} / 1$ e $1,4 \mathrm{U} / \mathrm{h} / \mathrm{h}$, respectivamente), considerada forte repressora à síntese da enzima.

Com relação às melhores condições de temperatura e pH, Macedo (1982) indicou que o $\mathrm{pH} \mathrm{4,0} \mathrm{e} \mathrm{a} \mathrm{temperatura} \mathrm{de} 35^{\circ} \mathrm{C}$ correspondiam às condições que levavam a uma maior produtividade em glicoamilase extracelular por Aspergillus niger NRRL $337 \mathrm{em}$ meio de cultura à base de farinha de mandioca. Chiquetto (1990) confirmou mais recentemente a preferência pelo cultivo a $\mathrm{pH} 4,0 \mathrm{em}$ relação a 5,0, tanto 
em meio a base de farinha de mandioca como glicose, trabalhando com Aspergillus awamori.

Já em relação à influência de oxigênio dissolvido na síntese de glicoamilase, encontram-se informações de certa forma contraditórias na literatura.

Alguns autores, como Aunstrup (1979), indicam que ao se operar em condições de limitação de oxigênio observa-se melhorias no rendimento. Searle e Tubb (1981), trabalhando com Saccharomyces diastaticus, também obtiveram maior produção de glicoamilase quando o oxigênio se tornou limitante.

$\mathrm{Na}$ direção oposta, encontram-se autores que afirmam que elevadas concentrações de oxigênio dissolvido influenciam favoravelmente a síntese de glicoamilase. Gracheva et al. (1973), cultivando Endomycopsis sp., indicam aumento de $75 \%$ na atividade do caldo ao elevar a velocidade de transferência de oxigênio de 3 para 22 $\mathrm{mgO}_{2} / \mathrm{m} / \mathrm{min}$. Andrzejczuk-Hybel et al. (1978) na mesma direção obtiveram considerável acréscimo na produção de glicoamilase por Aspergillus awamori NRRL $3112 \mathrm{em}$ meio a base de farelo de milho e amido de batata ao dobrarem a vazão de aeração, mantendo a frequência de agitação constante em $560 \mathrm{rpm}$.

Mais recentemente, Fachini (1988) estudando a influência das condições de transferência de oxigênio e da velocidade de respiração na síntese de glicoamilase por Aspergillus awamori NRRL 3112, confirmou que a relação entre a velocidade específica de respiração $\left(\mathrm{Q}_{\mathrm{O} 2}\right)$ e a velocidade específica de crescimento $(\boldsymbol{\mu})$ é linear, conforme a Equação 
(2.1), com o coeficiente de manutenção $\left(\mathrm{m}_{0}\right)$ em torno de $2 \mathrm{mmol} / \mathrm{g} / \mathrm{h}$ e o fator verdadeiro de conversão oxigênio a células $\left(\mathrm{Y}_{0}\right)$ de $0,05 \mathrm{~g} / \mathrm{mmol}$.

$$
\mathrm{O}_{2}=\mathrm{mo}_{\mathrm{O}}+\frac{1}{\mathrm{Yo}_{\mathrm{O}}} \cdot \mu
$$

Com relação a síntese de enzima, determinou ainda que a velocidade específica de produção de glicoamilase $(\mu \mathrm{A})$ variou com $\mathrm{Q}_{\mathrm{O} 2}$, segundo a Equação (2.2).

$$
\mu_{A}=\mu_{\text {máx }} \cdot \frac{\left(Q_{2}-m_{0}\right)}{K_{0}+\left(Q O_{2}-m_{0}\right)}
$$

onde $\mathrm{K}_{0}=0,55 \mathrm{mmol} / \mathrm{g} / \mathrm{h}$ e $\mu \mathrm{A}_{\text {máx }}$ varia com a concentração inicial de ART $\left(S_{o}\right)$, sendo $14 \mathrm{U} / \mathrm{g} / \mathrm{h}$ para $S_{0}=20 \mathrm{~g} / \mathrm{l}$ e $29 \mathrm{U} / \mathrm{g} / \mathrm{h}$ para $S_{0}=80 \mathrm{~g} / \mathrm{l}$. 


\subsection{Processos de produção de enzimas}

A primeira grande classificação para processos de produção de enzimas de origem microbiana refere-se ao meio de cultivo: semi-sólido (fermentação em superfície) e líquido (fermentação submersa).

Desde a pré-história, a fermentação semi-sólida é conhecida e utilizada no Oriente, em especial, no Japão. Baseia-se em um cultivo do microrganismo sobre um substrato particulado e úmido, usualmente farelo de trigo com vários nutrientes (Aunstrup, 1979). Após a esterilização, o substrato é inoculado com esporos de um fungo e distribuído em bandejas, que são incubadas em compartimentos semelhantes a uma estufa de grande porte, fazendo-se circular ar úmido e controlando-se a temperatura em torno de 30 a $35^{\circ} \mathrm{C}$. Terminada a fermentação, o farelo contendo as enzimas desejadas é enviado à extração e recuperação dessas, ou simplesmente secado e moído (IPT, 1987). Dessa forma, são produzidas glicoamilase por Rhizopus sp, pectinase e protease por Aspergillus niger, e $\alpha$-amilase e lactase por Aspergillus oryzae (Aunstrup, 1979).

A eficiência da fermentação semi-sólida na síntese de glicoamilase em relação à submersa não é sempre superior, no entanto. Park e Santi (1977) indicam uma produção inferior ao cultivar Aspergillus awamori em meio semi-sólido.

Mais recentemente, Kobayashi et al. (1990), na produção de glicoamilase por Aspergillus oryzae, desenvolveram um sistema para alimentação de meio líquido a um suporte poroso, permitindo controle da concentração de substrato em uma fermentação semi-sólida. 
Obtiveram atividade enzimática específica 2,5 superior ao processo em superfície tradicional.

O processo submerso, relativamente recente, é resultante dos progressos obtidos durante a década de 1940 para a síntese de penicilina. E, certamente na atualidade, o processo mais empregado para a produção de enzimas microbianas, sendo preferido em relação ao semi-sólido por facilitar a manutenção da assepsia e o monitoramento e controle das variáveis, como temperatura, $\mathrm{pH}$, agitação, aeração e concentração de nutrientes no meio de cultivo (Aunstrup, 1979).

Tipicamente, as fermentações submersas para produção industrial são efetuadas em grandes tanques com vários milhares de litros de capacidade, carregados com substrato e nutrientes e, a seguir, esterilizados. É feita, então, a inoculação com uma cultura de microrganismos, crescidos anteriormente num tanque menor (germinador). Nesse processo, todas as etapas devem ser realizadas com assepsia estrita, devendo ser esterilizado inclusive $o$ ar, constantemente introduzido no reator para a aeração do meio de cultivo. Terminada a fermentação, os microrganismos são separados por centrifugação ou filtração, e, sendo a enzima de interesse extracelular, esta é recuperada do meio límpido. No caso de enzima (ou qualquer outro produto) intracelular, as células separadas devem ser rompidas ou lisadas e a recuperação (down-stream processing) torna-se ainda mais complexa (IPT, 1987).

Acima, está descrito o processo descontínuo tradicional (batch) e, ainda, o dominante na produção industrial de enzimas. 
$\mathrm{Na}$ linha de pesquisa do Laboratório de Engenharia Bioquímica da EPUSP, vários trabalhos foram conduzidos com Aspergillus, visando a síntese de glicoamilase, em processo descontínuo, dentre eles, estudo da influência de: pH e temperatura (Macedo, 1982 e Aguero, 1987), condições de agitação e aeração (Fachini, 1988), meio de cultura (Chiquetto, 1990) e concentração de fonte de carbono (Facciotti, 1986 e Kilikian, 1989). Tais trabalhos e suas conclusões já foram anteriormente citados nos itens 2.2 e 2.3 .

Alternativamente ao processo descontínuo, outros tipos de processos de condução de uma fermentação tem sido desenvolvidos. Os mais clássicos são contínuo, semi-contínuo e descontínuo alimentado (fed-batch), mas há variantes destes, como por exemplo o descontínuo alimentado repetido.

Em um processo contínuo, o meio de cultura é continuadamente adicionado ao fermentador, com uma vazão normalmente constante, e o meio fermentado é retirado com a mesma vazão, de modo a se manter constante o volume de reação (Borzani et al., 1986). Em sua tese de Livre-Docência, Schmidell (1986) estudou esse processo na síntese de glicoamilase por Aspergillus niger NRRL 337, realizando vários ensaios com diferentes valores de vazão específica $D$ (razão entre a vazão volumétrica e o volume de fermentação), entre 0,05 e $0,357 \mathbf{h}^{-1}$. A máxima atividade enzimática no caldo $(30 \mathrm{U} / \mathrm{l})$ foi atingida com $\mathrm{D}=$ $0,15 h^{-1}$, que, embora inferior à $50 \mathrm{U} / 1$ verificada no cultivo descontínuo análogo, foi acompanhado por produtividade 1,5 vezes maior que a do ensaio batch. Obteve-se a maior produtividade (2,7 vezes superior à do descontínuo) no ensaio com $\mathrm{D}=0,357 \mathrm{~h}^{-1}$, apesar de apresentar 
elevadas concentrações residuais de substrato e baixa atividade enzimática.

No mesmo trabalho, estudou-se ainda a resposta do sistema, já em regime estacionário, a um pulso na corrente de alimentação, elevando rapidamente a concentração de açúcares redutores totais (S) de 0,5 a $10 \mathrm{~g} / \mathrm{l}$. Como resultado, a velocidade específica de síntese de glicoamilase elevou-se rapidamente, aumentando a atividade enzimática por algum tempo, até a volta ao estado estacionário.

Baseado nesse trabalho, passou-se ao estudo do processo semi-contínuo, que é uma adaptação do processo descontínuo visando uma utilização continuada do reator e inóculo. Inicia-se uma fermentação descontínua e após o esgotamento dos nutrientes, uma fração do caldo é retirada e reposta com meio de cultura original, iniciando-se mais um ciclo de semi-contínuo. Como consequência desse processo, gera-se uma brusca elevação na concentração de substrato (indutor), causando contudo, o esgotamento dos nutrientes. Facciotti (1986) utilizou esta técnica adotando valores de $S_{0}$ de 20,40 e $50 \mathrm{~g} / 1$ e frações de corte de 25, 50 e $75 \%$ do volume total. Seu melhor resultado foi obtido com $S_{0}$ de $40 \mathrm{~g} / \mathrm{A}$ e fração de corte $50 \%$, com produtividade de $120 \mathrm{U} / \mathrm{h} / \mathrm{h}$ (1,5 vezes superior à fase inicial descontínua) e atividade enzimática semelhante à da fase inicial.

\subsubsection{Processo descontínuo alimentado (fed-batch)}

O termo descontínuo alimentado (fed-batch) foi introduzido por Yoshida et al. (1973), referindo-se a uma cultura descontínua, 
continuadamente alimentada com nutrientes. Pirt (1975) apresenta a mesma definição e acrescenta que se uma fração da cultura é periodicamente removida, o sistema é chamado de descontínuo alimentado repetido (repeated fed-batch), sendo, portanto, uma combinação entre os processos semi-contínuo e descontínuo alimentado.

Com relação a terminologia, deve-se lembrar ainda que em Engenharia Química, este processo é às vezes denominado semi descontínuo (semi batch), ao lado de descontínuo alimentado (Yamane et al., 1976).

Yamane et al. (1976) apresenta uma definição mais ampla do processo, sendo aquele no qual um ou mais nutrientes são supridos ao reator de forma contínua ou intermitente, e os produtos permanecem no meio até o final do cultivo. Convém aqui salientar, que não se deve nesta definição, considerar o oxigênio, apesar de ser um nutriente (e às vezes, o substrato limitante), caso contrário a totalidade das fermentações aeróbias descontínuas seria englobada.

Yamane e Shimizu (1984), em extensa revisão sobre o tema, levanta como uma das principais vantagens do processo fed-batch, a possibilidade de se controlar a concentração de nutrientes durante a fermentação, pelo controle da vazão de alimentação.

Bailey e Ollis (1986) afirmam que frequentemente é desejável adicionar correntes líquidas a um bioreator descontínuo por uma série de motivos, em especial, para adição de indutores, extensão da fase estacionária para obtenção de maior quantidade de produto e minimização da repressão catabólica. 
Segundo Pirt, 1975 e Whitaker, 1980, o processo fed-batch tem atualmente sido aplicado na produção de antibióticos, aminoácidos, vitaminas, biomassa, glicerol, acetona-butanol, ácido lático e até no tratamento de águas residuárias. Com relação especificamente a enzimas, há, segundo os autores, poucos trabalhos, porém pode-se citar a produção de $\beta$-galactosidase, celulase, isoamilase, $\beta$-glucanase, $\beta$-amilase e protease, além de glicoamilase citada mais adiante.

Entre as várias vantagens no emprego do processo descontínuo alimentado já citadas por Yamane e Shimizu (1984) e Bailey e Ollis (1986), algumas serão aqui lembradas, através de exemplos de utilização.

Na síntese de glicoamilase por Penicillium expansum, Doyle et al. (1991) elevaram em 55\% a atividade enzimática, ao utilizar o processo fed-batch em relação ao descontínuo.

Também na fermentação penicilínica, o processo descontínuo alimentado apresenta vantagens. Por se tratar de um processo em duas fases, primeiramente o crescimento microbiano e em seguida produção de penicilina, o controle da vazão de alimentação de glicose permite estimular o crescimento na primeira etapa e limitá-lo na segunda, para aumentar a síntese do antibiótico (Stanbury e Whitaker, 1984).

No cultivo de Acidothermus cellulolyticus, Shiang et al. (1991) quase não observaram variações no crescimento celular ao utilizar o processo descontínuo alimentado, porém obtiveram significativos aumentos na produção de celulase. 
Também na sintese de enzimas celulolíticas, Persson et al. (1991) aumentaram a atividade enzimática e produtividade em 3 e 4 vezes, respectivamente, em ensaios fed-batch de Trichoderma sp.

Há vários processos onde é interessante manter a concentração de oxigênio dissolvido alta, o que nem sempre é possível nos cultivos descontínuos com limitação na capacidade de transferência de oxigênio para o meio (Pirt, 1974). Nesse sentido, Dawson et al. (1988) dobraram a produtividade na síntese de ácido cítrico por Aspergillus niger, com o processo descontínuo alimentado, devido a manutenção da concentração de oxigênio dissolvido acima de $40 \%$ e da limitação de nitrogênio.

O chamado efeito glicose ocorre quando, na produção de leveduras, há a produção de etanol mesmo na presença de quantidades suficientes de oxigênio dissolvido, devido ao excesso de açúcar no meio. Através do processo descontínuo alimentado, pode-se controlar o efeito glicose (Yamane e Shimizu, 1984).

Os processos descontínuos alimentados podem ser classificados em função da forma como a vazão de alimentação varia ao longo do cultivo (Yamane e Shimizu, 1984). Basicamente há aqueles com vazão fixa e os com vazão variável. Para tanto, é necessário um critério para a variação: pré-fixado em função de um modelo matemático ou com base em informações on-line.

Portanto, para um controle de processo em "feed-back" (retro-alimentado), é necessária instrumentação adequada que forneça medidas on-line. Crueger e Crueger (1984), por exemplo, usaram a 
medida do $\mathrm{pH}$ como forma de controle na produção de ácidos orgânicos.

Recentemente, Lelong et al. (1991) modificaram um bio-sensor comercial, de modo a terem uma medida semi-on-line (220 segundos de atraso) de glicose na faixa 41 a $0,05 \mathrm{~g} /$. Da mesma forma, Zeng et al. (1991) desenvolveram um método para estimativa da concentração de células viáveis, a partir da análise dos gases de saída. No caso, o processo fed-batch foi utilizado como mecanismo para controle de condições microaeróbias.

O controle da vazão de alimentação ao longo do cultivo potencializa as qualidades do processo fed-batch, porém não se consegue sempre definir uma boa estratégia de alimentação. 0 problema da otimização consiste em determinar uma programa para a variação da vazão, de modo a se buscar uma função objetivo, porém já existem sistemas prontos para este tipo de finalidade (Afschar et al., 1990).

Nos últimos anos, tem crescido o interesse na aplicação de teorias de controle ao processo descontínuo alimentado. A literatura apresenta vários exemplos de aplicação de teorias sobre modelos cinéticos de fermentação, normalmente sem apresentar dados experimentais que permitam a confirmação da validade do modelo e das técnicas de controle usadas, apesar de poucas exceções (Ananjin et al., 1991 e Shioya, 1992).

No Laboratório de Engenharia Bioquímica da EPUSP, alguns trabalhos já foram realizados no estudo do processo descontínuo 
alimentado na síntese de glicoamilase por Aspergillus awamori NRRL 3112.

Kilikian (1989), em sua tese de doutoramento, fixou a concentração total de ART (St) em $20 \mathrm{~g} / \mathrm{l}$, e variou a vazão de alimentação (fs), observando elevação na velocidade específica de síntese da enzima $(\mu \mathrm{A})$. Entre as três diferentes vazões estudadas, a que melhor resultou foi fs=22,5 $\mathrm{gART} / \mathrm{h}$, obtendo aumento na atividade enzimática máxima (Am) e na produtividade, de 92\% (960 U/l) e 70\% (46,0 U/1/h), respectivamente, em relação ao cultivo descontínuo.

Recentemente, Lessmann (1993) estudou o mesmo processo, porém com concentração de substrato bastante superior: 40 e 80 g/l, em uma região onde, em cultivo descontínuo, já se pode perceber inibição por substrato. Dos ensaios a $40 \mathrm{~g} / \mathrm{l}$, com vazão de alimentação (fs) de 32 gART/h, obteve aumento na Am de 53\% (3438 U/l) ao iniciar a alimentação no começo do cultivo e $42 \%$ (3177 U/1), com alimentação a partir de 4 horas de cultivo, com os mesmos aumentos percentuais na produtividade em relação ao processo batch. $O$ fator de conversão substrato a enzima (YA/S) se elevou de $76 \%(83,0 \mathrm{U} / \mathrm{g})$ e $69 \%(79,6 \mathrm{U} / \mathrm{g})$, respectivamente.

Nos ensaios a $S_{0}$ de $80 \mathrm{~g} / 1$, Lessmann (1993) só obteve aumentos significativos em seus resultados, quando impôs uma maior vazão de alimentação (fs=32gART/h), atingindo 5267 U/l (32\% de aumento), no ensaio com a alimentação desde o começo do cultivo, e 5140 U/1 (aumento de 29\%) com alimentação a partir de 4 horas de cultivo. 0 aumento na produtividade em enzima foi de $30 \%$ e 20\%, respectivamente, enquanto que YA/S sofreu elevação de 22 e $20 \%$. Ao 
diminuir fs, para 22 e 16 gART/h, alimentando desde o início do cultivo, o autor obteve redução na Am de 12 e $26 \%$, respectivamente, em relação ao ensaio descontínuo análogo, mostrando que nem sempre é vantajoso o processo fed-batch. Lessmann apresenta, ainda, um ensaio com vazão variável pré-determinada, segundo um equacionamento matemático do sistema, obtendo Am 9\% superior (5400 U/1) ao ensaio batch, realizado simultaneamente. 


\section{MATERIAIS E METODOS}

\subsection{Microrganismo}

\subsubsection{Linhagem}

Empregou-se uma cultura pura de Aspergillus awamori NRRL 3112, obtida na forma liofilizada junto ao Northern Regional Research Center, órgão pertencente ao Departamento de Agricultura dos Estados Unidos.

\subsubsection{Conservação}

A cultura liofilizada recebida foi conservada em tubos contendo uma mistura de terra e areia previamente esterilizada, segundo método proposto por Greene e Fred (1934) para a conservação de fungos por períodos longos, com algumas modificações, segundo Facciotti (1986).

Para que seja possível uma clara descrição do método de conservação do microrganismo, descrever-se-á inicialmente o meio Czapek e os tubos com terra e areia.

Preparo dos tubos com terra e areia

a.Pesaram-se cerca de $200 \mathrm{~g}$ de terra preta de jardim, secou-se em estufa a $80-85^{\circ} \mathrm{C}$ até peso constante e peneirou-se a 60 mesh. Igualmente foi 
feito com cerca de $200 \mathrm{~g}$ de areia de quartzo, previamente lavada, conforme técnica descrita por Macedo (1982).

b.Foram pesados diretamente em tubos de ensaio, $2 \mathrm{~g}$ de areia e $3 \mathrm{~g}$ de terra (razão de $40 \%$ areia / $60 \%$ terra). Em seguida, os tubos foram agitados para homogeneizar bem a terra e areia, e tampados com rodilhões de algodão.

c.A seguir, foram submetidos a tratamento térmico em autoclave a $120^{\circ} \mathrm{C}$, durante 30 minutos, por 3 vezes, em dias alternados, sendo que entre um tratamento térmico e o seguinte, estes eram incubados em estufa a $30^{\circ} \mathrm{C}$. Após o último, os tubos foram secados em estufa a $100^{\circ} \mathrm{C}$, por 24 horas. Antes de seu uso, procedia-se ainda, um teste de esterilidade com alguns.

\section{Preparo do Meio Czapek}

O meio de cultura sólido, empregado para o cultivo do microrganismo em placas e em tubos, denominado meio Czapek, apresenta a seguinte composição (Raper e Fennell, 1965): 


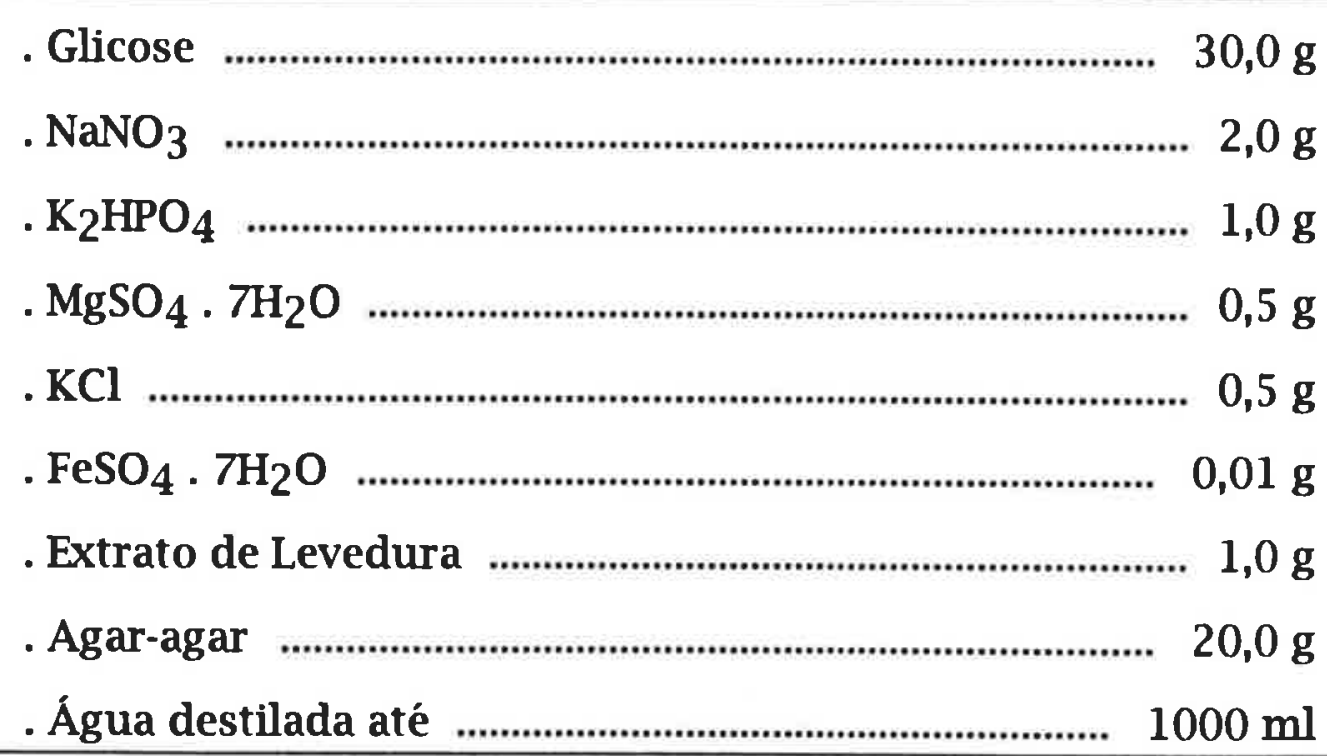

Este meio era distribuido a quente nos tubos ou placas, colocando-se $5 \mathrm{ml}$ (tubos) ou $20 \mathrm{ml}$ (placas) em cada, e esses eram, em seguida, submetidos à esterilização em autoclave a $120^{\circ} \mathrm{C}$, durante 20 minutos e então deixados em posição inclinada para a solidificação do meio.

\section{Descrição Método de Conservação}

a.Suspendeu-se a cultura liofilizada da NRRL em tubo contendo $1 \mathrm{ml}$ de água destilada esterilizada.

b.Com essa suspensão, foram inoculadas duas placas de Petri, contendo cada $20 \mathrm{ml}$ de meio Czapek, que foram incubadas a $30^{\circ} \mathrm{C}$, até o aparecimento de colônias isoladas.

c.Escolheu-se uma das duas placas e a partir das colônias existentes nela, inocularam-se 5 tubos contendo cada $5 \mathrm{ml}$ de meio Czapek inclinado, que permaneceram incubados a $30^{\circ} \mathrm{C}$, por 4 a 5 dias. 
d.A partir dos 5 tubos anteriores, 15 novos foram inoculados e também incubados nas mesmas condições.

e.A cada um dos 15 tubos, contendo a cultura já esporulada, foram adicionados $4 \mathrm{ml}$ de água destilada esterilizada, agitando-se vigorosamente cada tubo para suspender os esporos.

f.A partir dos 15 tubos anteriores, 40 tubos contendo a mistura de terra e areia foram inoculados, pipetando-se $1 \mathrm{ml}$ da suspensão de esporos em cada, com pipetas volumétricas esterilizadas, contendo algodão no bocal.

g.Os tubos com terra e areia, recém-inoculados, foram a seguir incubados a $30^{\circ} \mathrm{C}$. Diariamente eram agitados, com o intuito de se soltar bem a mistura de terra e areia e não se formarem grumos. Após alguns dias, quando se observou a mistura bastante solta, os tubos foram armazenados em geladeira, até seu uso no preparo do inóculo.

\subsubsection{Preparo do Inóculo}

A partir de um tubo com terra e areia armazenado, conforme item 3.1.2, adotou-se para o preparo do inóculo o procedimento descrito a seguir. Convém observar que, simultaneamente, três ensaios eram realizados, de modo que o procedimento descrito gerava o inóculo dos três ensaios.

a.Uma pequena fração de terra e areia era retirada do tubo, com uma espátula de aço inoxidável esterilizada, e espalhada assepticamente 
em um erlenmeyer de $250 \mathrm{ml}$, contendo $100 \mathrm{ml}$ de meio Czapek inclinado, procurando-se espalhar a porção de terra e areia por toda a superfície do meio solidificado. Igualmente, preparavam-se outros três erlenmeyers.

b.Os quatro erlenmeyers eram então incubados a $30^{\circ} \mathrm{C}$, durante 5 dias, tempo suficiente para que toda a superfície do meio sólido ficasse totalmente coberta por esporos do microrganismo inoculado anteriormente.

c.Após esse período, eram escolhidos três erlenmeyers, nos quais a esporulação se mostrou completa e suspendiam-se os esporos, adicionando-se a cada erlenmeyer escolhido $60 \mathrm{ml}$ de uma solução de um agente tensoativo, chamado Tween-R40 (Atlas Chemical Industries Inc.), na concentração de $15 \mathrm{mg} /$, contendo um conjunto de pérolas de vidro.

d.Substituía-se assepticamente o rodilhão de algodão de cada erlenmeyer por uma rolha de borracha esterilizada e se procedia a uma vigorosa agitação dos frascos, durante um minuto, para se permitir a completa suspensão dos esporos, motivo da adição das pérolas de vidro.

e.As suspensões obtidas eram, então, transferidas de modo asséptico para um único erlenmeyer de $250 \mathrm{ml}$, vazio, seco e esterilizado, totalizando portanto, cerca de $180 \mathrm{ml}$ de suspensão de esporos.

f.Com essa suspensão, inoculavam-se 18 erlenmeyers de 1 litro contendo cada $200 \mathrm{ml}$ de meio de cultura líquido a concentração de ART de 20g/1, preparado conforme metodologia descrita no item 3.2. A inoculação era feita transferindo-se assepticamente $5 \mathrm{ml}$ da 
suspensão de esporos para cada um dos frascos, com pipetas volumétricas esterilizadas, com algodão no bocal.

g.Os 18 erlenmeyers inoculados eram, então, levados a um incubador rotativo, ou "shaker" (New Brunswick Sc. Co., modelo G-25) à temperatura de $35^{\circ} \mathrm{C}$ e frequência de agitação de 200 r.p.m., por um período de 24 horas. Tal período foi determinado como ideal por Facciotti (1986), por corresponder a elevadas velocidades de crescimento celular, reduzindo a fase de adaptação (lag) do cultivo posterior em fermentador.

h.Terminado esse período em incubador rotativo, eram escolhidos os 15 frascos com aspecto mais uniforme e realizada a adição do conteúdo deles, de modo a se ter três frascos com cerca de 1 litro em cada, prontos para a inoculação de cada um dos três fermentadores, conforme será visto no item 3.3. 


\subsection{Meio de Cultura}

\subsubsection{Principal Matéria Prima}

Em todos os ensaios, utilizou-se um meio de cultura, contendo um xarope de farinha de raspa de mandioca como principal fonte de carbono. Esta farinha foi obtida da empresa Ricieri Pechatt \& Filhos (Araras, SP) e estocada, em nossos laboratórios, em sacos plásticos mantidos fechados.

Suas principais características foram determinadas por Macedo (1982), tendo-se obtido:

Teor de amido $80,2 \%$

. Teor de umidade $12,3 \%$

. Teor de fibras $5,1 \%$

. Teor de açúcares redutores $2,4 \%$

\subsubsection{Preparo do Meio de Cultura}

Utilizou-se para os cultivos em fermentador, bem como em incubador rotativo no preparo do inóculo, um meio de cultura líquido, elaborado a partir de um xarope de farinha de mandioca. 0 preparo deste xarope, de alta concentração de ART, esta descrito a seguir.

a.Em uma panela de aço inoxidável, à qual se adaptava uma agitador mecânico, colocava-se um volume adequado de uma solução $0,01 \mathrm{M}$ de 
$\mathrm{CaCl}_{2}$ em $\mathrm{NaOH}$ 0,01M e adicionava-se a farinha de raspa de mandioca descrita no item 3.2.1, de forma a se ter cerca de $380 \mathrm{~g}$ de farinha por litro de suspensão. Empregou-se uma solução de $\mathrm{CaCl}_{2}$, pois o cálcio é um estabilizante da enzima $\alpha$-amilase, que será adicionada posteriormente.

b.Após a homogeneização, acertava-se o pH da suspensão para um valor entre 6,0 e 6,5, intervalo ótimo para ação da $\alpha$-amilase.

c.Aquecia-se a suspensão, sob agitação constante, até a temperatura aproximada de $55^{\circ} \mathrm{C}$, quando se adicionavam, por litro de suspensão, $0,3 g$ de $\alpha$-amilase bacteriana (Laboratório Okochi Ltda.), com potência nominal de $2200 \mathrm{SKB} / \mathrm{g}$. A temperatura em questão é inferior à de gelatinização do amido de mandioca $\left(63^{\circ} \mathrm{C}\right)$.

d.Elevava-se a temperatura até $90^{\circ} \mathrm{C}$, ótima para ação da $\alpha$-amilase, permanecendo nessa condição durante 10 minutos. Em seguida, levava-se a suspensão a ebulição por 5 minutos, a fim de se inativar a enzima.

e.Filtrava-se então, a vácuo, a suspensão assim preparada, utilizando-se papel de filtro Carl Schleicher \& Schull $589^{2}$. A filtração possibilita a determinação da concentração celular por massa seca, ao produzir um xarope limpido.

f.Dosavam-se no xarope filtrado obtido, as concentrações de glicose e açúcares redutores totais (ART), segundo metodologia descrita nos itens 3.4.2 e 3.4.3, obtendo-se concentrações da ordem de 5 e $300 \mathrm{~g} /$, respectivamente. 
Uma vez conhecida a concentração de ART no xarope, utilizava-se um volume adequado para se obter a concentração de ART desejada no meio de cultura líquido. Em fermentador foram realizados ensaios a concentração inicial de ART $\left(\mathrm{S}_{\mathrm{o}}\right)$ de 20 e $40 \mathrm{~g} / \mathrm{l}$, enquanto que para o inóculo manteve-se sempre a concentração de $20 \mathrm{~g} / 1$. Nos ensaios com $S_{0}$ de $40 \mathrm{~g} /$, a concentração de todos nutrientes foi dobrada.

Completava-se o preparo do meio líquido com a adição de nutrientes e água destilada, segundo Macedo (1982) e Schmidell (1986), de modo que a composição final no fermentador e no meio para inóculo era:

- extrato de levedura $0,10 \mathrm{~g} / 1$

. $\mathrm{MgSO}_{4} \cdot 7 \mathrm{H}_{2} \mathrm{O}$ $0,50 \mathrm{~g} / \mathrm{l}$

. $\left(\mathrm{NH}_{4}\right)_{2} \mathrm{SO}_{4}$ $5,00 \mathrm{~g} / \mathrm{l}$

. $\mathrm{Na}_{2} \mathrm{HPO}_{4} \cdot 12 \mathrm{H}_{2} \mathrm{O}$ $3,78 \mathrm{~g} / 1$

. $\mathrm{KH}_{2} \mathrm{PO} 4$ $3,50 \mathrm{~g} / 1$

. açúcares redutores totais $20 \mathrm{~g} / 1$

No meio de cultura a ser utilizado nos fermentadores, adicionava-se ainda o antiespumante UCON (polialquileno glicol), fabricado pela Union Carbide Corporation, na proporção de $0,08 \mathrm{ml} / 1$ de meio e em seguida acertava-se o $\mathrm{pH}$ para o valor de 4,0. Este anti-espumante era igualmente adicionado ao fermentador ao longo do cultivo, ocasionalmente, quando a altura da camada de espuma sobre o líquido atingia cerca de $2 \mathrm{~cm}$.

O meio de cultura a ser empregado no inóculo, em incubador rotativo, tinha seu $\mathrm{pH}$ ajustado para 5,0 e era distribuído em 
erlenmeyers de 1 litro, colocando-se $200 \mathrm{ml}$ em cada, conforme visto no item 3.1.3.

Como não se conseguia a transferência por bombeamento de todo o volume de meio preparado para o fermentador, se preparava um volume ligeiramente maior que o necessário, com concentrações dos vários nutrientes e ART adequadamente elevadas, de modo que as concentrações no fermentador após a transferência estivessem conforme desejado e citado acima.

Para os ensaios descontínuos, preparava-se 10,0 litros em balão de 12l, e apenas 9,0l eram transferidos, de modo que com a adição de 1,0 litro de inóculo (10\%), obtinha-se 10 litros de meio inoculado a $S_{0}$ de 20 ou $40 \mathrm{~g} / 1$.

Para os ensaios descontínuos alimentados, a quantidade de xarope adicionada na preparação do meio era calculada de modo a se iniciar com $S_{0}$ de $2,0 \mathrm{~g} / 1$ e todo o xarope adicional, para totalizar a quantidade de ART necessária para a concentração total de ART (St), era alimentado a parte no decorrer do ensaio. Assim, a alimentação era constituída apenas de xarope de farinha, tendo sido todos os nutrientes já adicionados no início do ensaio.

Desse modo, nos ensaios descontínuos alimentados, eram preparados 9,5 litros em balão de 12l, e apenas 8,46 litros eram transferidos, que, adicionados a 0,94 litros de inóculo, perfaziam 9,4 1 iniciais, correspondendo a inóculo de 10\%. Tal volume era, ao longo da alimentação, adicionado de cerca de 0,61 ou 1,21 de xarope nos ensaios a St de $20 \mathrm{~g} / \mathrm{l}$ ou $40 \mathrm{~g} / \mathrm{l}$, respectivamente. 


\subsection{Ensaios Realizados}

Foram realizados 16 ensaios em fermentador, 6 descontínuos e 10 descontínuos alimentados. A Tabela 3.1 apresenta cada ensaio, com sua denominação e características principais. Outras características, comuns a todos ensaios, serão mostradas adiante.

A denominação de cada ensaio tentou seguir algumas diretrizes, de modo a facilitar a associação ensaio-denominação. Os ensaios descontínuos (batch) iniciam com $B$, enquanto que os descontínuos alimentados (fed-batch) com F. Segue um número representativo da concentração inicial de ART ( $S_{0}$ ou St), isto é, 2 para $20 \mathrm{~g} / 1$ e 4 para $40 \mathrm{~g} /$. Dentro desta classificação, o terceiro caractere serve para diferenciar ensaios semelhantes: B21, B22, B23 e B24 são semelhantes, realizados em diferentes datas. Da mesma forma, F21, F22, etc... diferenciam-se pela vazão de alimentação empregada. $O$ último caractere de determinados ensaios associa-se a características especiais: I, alimentado desde o início e $\mathrm{H}$, alimentado com xarope previamente hidrolisado.

A Tabela 3.2 apresenta os mesmos ensaios na ordem em que foram realizados, que, conforme será visto adiante no item 4.2 .5 , pode influir em termos de tempo de preservação da linhagem. 
Tabela 3.1 Descrição dos Ensaios Realizados

\begin{tabular}{|cccccc|}
\hline Ensaio & $\begin{array}{c}\text { So ou St } \\
(\mathrm{g} / \mathrm{l})\end{array}$ & $\begin{array}{c}\text { fs } \\
(\mathrm{gART} / \mathrm{h})\end{array}$ & $\begin{array}{c}\Delta \theta \\
\text { (h) }\end{array}$ & $\begin{array}{c}\theta_{\mathrm{o}} \\
\text { (h) }\end{array}$ & xarope \\
B21 & 23,1 & & & & \\
B22 & 24,1 & & & & \\
B23 & 20,7 & & BATCH & & \\
B24 & 21,5 & & & & \\
B41 & 44,7 & & & & \\
B42 & 42,3 & & 13,5 & 4 & normal \\
F21 & 22,0 & 13,3 & 10,5 & 4 & normal \\
F22 & 21,2 & 17,1 & 7,6 & 4 & normal \\
F23 & 20,9 & 23,7 & 5,6 & 4 & normal \\
F24 & 21,5 & 32,1 & 5,7 & 4 & hidrolisado \\
F2H & 21,4 & 31,6 & 5,7 & 0 & normal \\
F2I & 23,2 & 31,6 & 26,2 & 4 & normal \\
F41 & 41,2 & 14,5 & 18,3 & 4 & normal \\
F42 & 40,8 & 20,8 & 11,8 & 4 & normal \\
F43 & 41,0 & 32,2 & 18,0 & 4 & hidrolisado \\
F4H & 40,4 & 21,1 & & & \\
\hline
\end{tabular}


Tabela 3.2 Contemporaneidade dos Ensaios Realizados

\begin{tabular}{|ccc|}
\hline $\begin{array}{c}\text { Data de } \\
\text { realização } \\
\text { dos ensaios }\end{array}$ & $\begin{array}{c}\text { Tempo de preservação } \\
\text { em terra e areia } \\
\text { (meses) }\end{array}$ & Ensaios \\
$15 / 08 / 90$ & 5 & B21, F22 e F23 \\
$11 / 09 / 90$ & 6 & B22, F21 e F24 \\
$17 / 10 / 90$ & 7 & B23, F2I e F2H \\
$29 / 01 / 91$ & 10 & B24 \\
$10 / 04 / 91$ & 13 & B41, F42 e F43 \\
$15 / 06 / 91$ & 15 & B42, F41 e F4H \\
\hline
\end{tabular}

Todos os ensaios foram realizados em fermentadores Biolafitte (França), empregando tanque cilíndrico de 15 litros de capacidade, com $20 \mathrm{~cm}$ de diâmetro e $48 \mathrm{~cm}$ de altura. $O$ volume líquido utilizado era de aproximadamente 10 litros.

Como sistema de agitação, empregou-se, no eixo central, três turbinas com $8,9 \mathrm{~cm}$ de diâmetro, do tipo pás planas (flat-blade turbine), com quatro pás em cada uma. As turbinas foram posicionadas de maneira a manter, entre si, uma distância igual ao seu diâmetro, segundo Bates et al., 1963, sendo a primeira delas colocada no fundo do tanque, logo acima do dispersor de ar. Para evitar a formação de vortex durante a agitação, o tanque dispõe de 4 chicanas de espessura de $2 \mathrm{~cm}$ cada, também utilizadas como serpentinas para circulação da água de aquecimento/resfriamento.

Este tanque está acoplado a um armário de controle, que permite medir e controlar uma série de variáveis ao longo do cultivo. Os sistemas utilizados foram: 
- controle da temperatura de esterilização

- controle da temperatura de fermentação

- controle do $\mathrm{pH}$

- medida e fixação da frequência de agitação

- medida e fixação da vazão de ar

- medida e fixação da pressão interna do reator

A temperatura, seguindo Macedo (1982), foi fixada em $35^{\circ} \mathrm{C}$, controlada por aquecimento da água de circulação ou substituição desta por água fresca. $O$ controle do $\mathrm{pH}$, fixo em 4,0, era realizado através da adição de uma solução de $\mathrm{NaOH} 2 \mathrm{~N}$, através de uma bomba peristáltica, acionada automaticamente pelo sistema de medida e controle. Após o término da fonte de carbono, o sistema requeria para a manutenção do pH fixado, a adição de ácido, realizada similarmente com uma solução de $\mathrm{HCl} 2 \mathrm{~N}$.

A frequência de agitação foi fixada em 700 r.p.m. e a vazão de ar em 10 litros normais por minuto, o que equivale a 1 v.v.m. (volume de ar por volume de meio de cultivo por minuto).

A pressão interna do fermentador foi fixada em $0,2 \mathrm{kgf} / \mathrm{cm}^{2}$ acima da pressão atmosférica ambiente (sobre-pressão, portanto). Seu valor era obtido através de uma sonda colocada na cabeça do tanque. Devido ao mau funcionamento do sistema atuador de controle da pressão (válvula agulha), esta era mantida em seu valor pré-fixado através de uma pinça na tubulação de saída de gases do reator, ajustada manualmente. 
Por problemas de vazamento nos eletrodos galvânicos, a concentração de oxigênio dissolvido não pôde ser medida nos ensaios, apesar de ser um dado importante na análise de fermentações aeróbias, em especial em ensaios descontínuos alimentados.

\subsubsection{Preparo do Fermentador e dos Sistemas de Medida}

Ao tanque de fermentação se acoplavam as sondas para medida da temperatura, $\mathrm{pH}$ e pressão interna. Instalavam-se, também, o condensador de umidade arrastada pelo fluxo gasoso e os filtros de metal sinterizado para esterilização do ar de entrada e gases de saída do reator.

Em seguida, adicionavam-se 8 litros de água ao reator e iniciava-se o aquecimento do conjunto pela introdução de vapor indireto pelas chicanas. Ao se atingir a temperatura de ebulição, iniciava-se a introdução de vapor direto na cabeça do tanque, esterilizando-se, dessa forma, as tubulações de entrada e saída do fermentador durante 15 minutos. A seguir, elevava-se a temperatura até $120^{\circ} \mathrm{C}$, mantendo-se esta condição por 20 minutos.

Terminada esta operação de esterilização, resfriava-se o fermentador até $35^{\circ} \mathrm{C}$, através da circulação de água no sistema de troca térmica do reator.

Usualmente essa operação de esterilização era realizada no dia anterior ao de início do ensaio. Portanto, uma vez encerrada, 
desligavam-se os sistemas de controle e o fermentador permanecia hermeticamente fechado durante, aproximadamente, 15 horas.

No dia do ensaio, drenava-se inicialmente a água contida no interior do reator e procedia-se à transferência, de forma asséptica, do meio de cultura líquido, preparado segundo procedimento descrito no item 3.2. Após essa transferência, iniciava-se a agitação, a aeração e o aquecimento do líquido.

Entre o instante de transferência do meio e a inoculação do tanque, transcorriam cerca de duas horas, tempo este necessário para a estabilização dos eletrodos e das condições de cultivo, bem como calibração das sondas e acoplamento, ao fermentador, das soluções de $\mathrm{NaOH}, \mathrm{HCl}$ e UCON, para controle do $\mathrm{pH}$ e nível de espuma.

Após a inoculação, retiravam-se amostras periodicamente, que eram analisadas segundo procedimento descrito no item 3.4. Os ensaios a $S_{0}$ de $20 \mathrm{~g} / \mathrm{eram}$ amostrados a cada 2 horas, enquanto que os a $S_{0}$ de $40 \mathrm{~g} /$, a cada 3 horas. A partir do início do consumo da solução de $\mathrm{HCl}$ para controle do $\mathrm{pH}$, correspondendo supostamente ao fim da fonte de carbono, eram retiradas ainda mais duas amostras, sendo assim o ensaio considerado concluído. Dessa forma, os ensaios a $S_{0}$ de $20 \mathrm{~g} / \mathrm{A}$ tiveram uma duração de cerca de 26 horas, enquanto que os outros, 36 horas.

Nos ensaios descontínuos, como toda a fonte de carbono era adicionada desde o início, o meio de reação era alterado basicamente pela retirada de amostras e adição das soluções para controle de $\mathrm{pH}$ e nivel de espuma. 


\subsubsection{Ensaios Descontinuos Alimentados}

Todo o preparo dos ensaios descontínuos alimentados era realizado similarmente aos descontínuos, com a diferença básica de que era transferido um menor volume de meio de cultura, com concentração de ART inferior, conforme visto no item 3.2.2.

O meio de alimentação, composto de xarope de farinha de mandioca concentrado, era mantido em um erlenmeyer de 2 litros sobre uma balança semi-analítica, acoplado ao fermentador através de uma bomba peristáltica de vazão ajustável (Incibrás, modelo BP-100).

Para cada ensaio, após a esterilização deste erlenmeyer, pesava-se o xarope a alimentar, de modo a se conhecer a relação entre massa de xarope e massa de ART, e calculava-se assim a vazão mássica de xarope desejada (g xarope/h), para se impor determinada vazão mássica de alimentação, fs (gART/h).

Em todos os ensaios descontínuos alimentados, a vazão de alimentação foi mantida fixa, durante todo o ensaio. Para tanto, se media periodicamente a diminuição da massa de xarope no erlenmeyer e se calculava a vazão resultante, ajustando-se o controle de vazão da bomba peristáltica. Uma noção aproximada da posição do dial de controle da bomba já era conhecida, graças a uma calibração feita anteriormente. 


\section{Preparo do Xarope Hidrolisado}

Nos ensaios F2H e F4H, o xarope do meio de alimentação foi previamente hidrolisado, a fim de converter todo polissacarídeo em glicose e eliminar a indução do microrganismo à síntese de glicoamilase. Para tanto, foi preparado, inicialmente, o xarope como nos outros ensaios.

Para o ensaio F2H, distribuiu-se $1000 \mathrm{ml}$ de xarope em 4 erlenmeyers de $500 \mathrm{ml}$ e se adicionou a cada $1,2 \mathrm{ml}$ de enzima glicoamilase comercial (Pfizer, potência nominal de $260 \mathrm{U} / \mathrm{ml}$ ). Acertou-se o pH para 4,1 e mantiveram-se os erlenmeyers em incubador rotativo à temperatura de $45^{\circ} \mathrm{C}$, por 16 horas, sob agitação a 150 r.p.m.

Após este período de hidrólise, adicionou-se o conteúdo dos 4 erlenmeyers e efetuou-se a dosagem da concentração de açúcares redutores totais e de glicose, conforme itens 3.4.2 e 3.4.3., cujos resultados obtidos, dentro da precisão do método, indicavam a completa hidrólise dos polissacarideos presentes no xarope original.

Para o ensaio F4H, adotou-se procedimento semelhante, produzindo-se o dobro da quantidade de xarope hidrolisado, por se tratar de ensaio a $S t=40 \mathrm{~g} /$. 


\subsection{Controles Analíticos}

As amostras coletadas ao longo de um cultivo foram submetidas, inicialmente, a um rápido resfriamento, agitando-se o frasco com a amostra em um banho com gelo e água. A finalidade desse resfriamento era a diminuição da ação microbiana e enzimática, de modo a permitir a maior precisão possivel nas determinações posteriores.

Em sequência, o pH era medido, como forma de se verificar se o sistema de medida e controle do $\mathrm{pH}$ do fermentador operava corretamente, e pesava-se o total de amostra retirado do fermentador, para posterior balanço de volume:

As amostras eram então submetidas às seguintes dosagens:

. concentração celular;

. concentração de glicose;

. concentração de açúcares redutores totais (ART);

. determinação da atividade da glicoamilase.

Na Figura 3.1 indica-se um esquema simplificado do tratamento analítico das amostras, que será descrito em maiores detalhes nos itens a seguir, lembrando-se que esse tratamento é semelhante ao já descrito em outros trabalhos (Facciotti, 1986, Schmidell, 1986 e Kilikian, 1989).

Cumpre ressaltar ainda, que se trabalhou com um bolor que cresce tanto na forma de pequenas esferas ("pellets"), como de micélio em suspensão no meio. Além disso o crescimento foi igualmente acompanhado por uma significativa elevação da viscosidade aparente. 
Esses fatos tornaram inviável colher um volume conhecido da

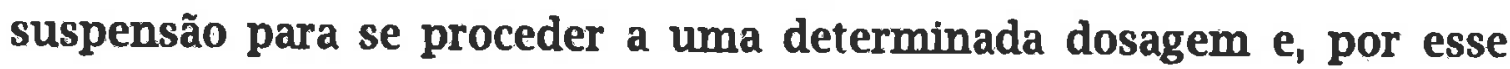
motivo, tomaram-se amostras por pesagem em balança analítica, considerando-se nos cálculos a densidade relativa da águá como sendo unităria. 


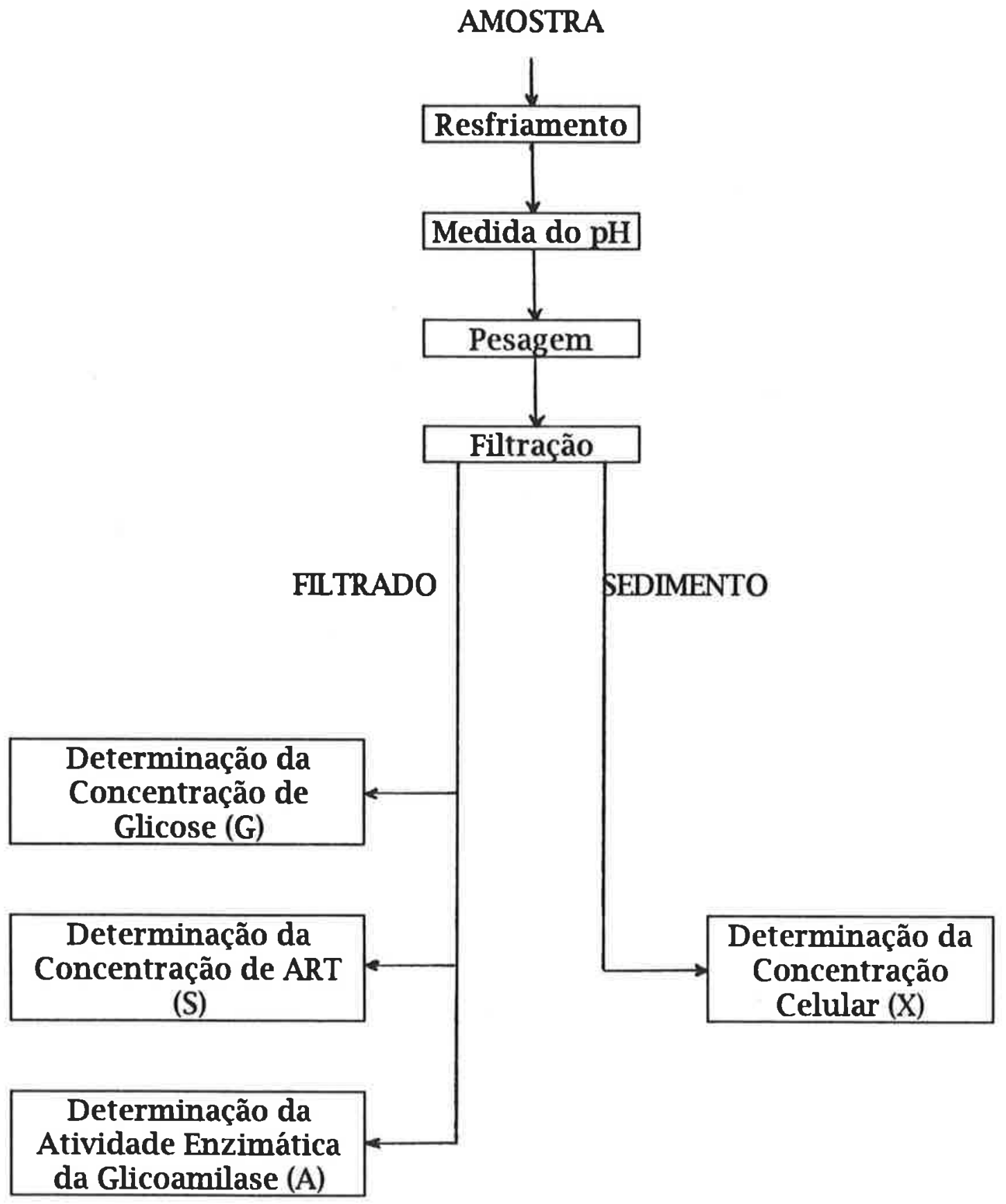

Figura 3.1 Esquema do tratamento analítico das amostras dos ensaios de cultivo de Aspergillus awamori NRRL 3112. 


\subsubsection{Determinação da Concentração Celular (X)}

A concentração celular foi obtida segundo procedimento descrito por Schmidell e Fernandes (1976).

Conforme indicado na Figura 3.1, uma fração da amostra inicialmente pesada em balança analítica (Mettler, modelo H10T) era submetida a uma filtração através de papel de filtro Carl Schleicher \&

Schull 5892, adaptado a um sistema de filtração à vácuo (Millipore Corp. - no catálogo XX10-047-00).

Recolhia-se o filtrado em frasco adequado, com o intuito de se proceder às determinações apresentadas nos itens 3.4 .2 , 3.4.3 e 3.4.4. Em seguida, lavava-se o sedimento retido por duas vezes com água destilada e submetia-se o mesmo a uma secagem em estufa a $85^{\circ} \mathrm{C}$ com circulação natural de ar, até massa constante, sendo necessário para tal finalidade, um periodo de 5 horas.

Em paralelo, procedia-se à determinação da umidade do papel de filtro, colocando-se na estufa algumas amostras desse papel e secando-se igualmente, por um período de 5 horas.

Após esse período, pesava-se a massa seca de células, descontando-se a massa do papel de filtro e sua umidade, e calculava-se a concentração celular, expressa em gramas de matéria seca por litro de amostra, considerando-se a densidade da amostra como unitária. 


\subsubsection{Determinação da Concentração de Glicose (G)}

Essa dosagem era executada no filtrado da mesma amostra destinada à determinação da concentração celular (item 3.4.1).

Após a filtração, pipetava-se uma alíquota do filtrado em um balão volumétrico colocado com alguns mililitros de água destilada em banho fervente, durante 5 minutos, para a inativação das enzimas presentes. Desta forma, podia-se determinar a quantidade de glicose na amostra, sem permitir a hidrólise dos polissacarídeos, pela presença de hidrolases.

Aguardava-se, então, o resfriamento da amostra e se completava o balão com água destilada, realizando assim a diluição conveniente, e procedia-se à dosagem de glicose, segundo o procedimento descrito no item 3.4.5.

\subsubsection{Determinação da Concentração de ART - Açúcares Redutores Totais (S)}

Essa determinação foi efetuada através da hidrólise enzimática dos polissacarídeos presentes na amostra, segundo a técnica desenvolvida por Schmidell e Fernandes (1977). 


\section{Reagentes}

a.Solução de tampão citrato ( $\mathrm{pH}=4,8)$ : preparava-se uma solução $0,05 \mathrm{M}$ de ácido cítrico (p.a.) e ajustava-se o $\mathrm{pH}$ para o valor 4,8, utilizando-se solução de $\mathrm{NaOH} 2 \mathrm{~N}$.

b. Solução de amiloglicosidase: utilizava-se uma solução de amiloglicosidase (Sigma Chem. Co.), com atividade nominal de $260.000 \mathrm{U} / 1 \mathrm{em}$ solução $1 \mathrm{M}$ de glicose, contendo $0,5 \%$ de benzoato de sódio, diluída 200 vezes com a solução de tampão citrato.

\section{Procedimento para a dosagem}

Em balão volumétrico, adicionavam-se $10 \mathrm{ml}$ da solução de amiloglicosidase e um determinado volume de filtrado. $O$ volume do balão, assim como o volume do filtrado a ser submetido à hidrólise, eram escolhidos de forma que, após a hidrólise, obtinha-se uma solução onde a concentração de glicose estivesse na faixa de 0,2 a $1,0 \mathrm{~g} /$, intervalo de concentração definido pelo método de dosagem descrito no item 3.4.5.

Em seguida, homogeneizava-se o conteúdo do balão, que era levado a um banho termostático (Fanem Ltda., modelo $112 / 3$ ) a $45^{\circ} \mathrm{C}$ por 30 minutos.

Inativava-se então, a enzima presente, colocando-se $o$ balão volumétrico em um banho de água fervente durante 5 minutos. Após o resfriamento do balão, completava-se o volume com água destilada e procedia-se à dosagem da concentração de glicose pelo método da glicose-oxidase descrito no item 3.4.5. 
A concentração de açúcares redutores totais, expressa como glicose, era obtida pela Equação (3.1).

$$
\mathrm{ART}=\frac{0,977(\mathrm{Gm}-\mathrm{Gi}-\mathrm{GE})}{0,9}+\mathrm{G}_{\mathrm{i}}
$$

onde:

ART $=$ concentração de açúcares redutores totais na amostra $(g / 1)$

$\mathrm{Gm}=$ concentração de glicose na amostra após a hidrólise $(\mathrm{g} / \mathrm{l})$

$\mathrm{Gi}=\quad$ concentração de glicose inicialmente presente na amostra e determinada pelo procedimento indicado no item $3.4 .2(\mathrm{~g} / \mathrm{l})$

$\mathrm{GE}=$ concentração de glicose devido à glicose presente na amiloglicosidase comercial ( $\mathrm{g} / \mathrm{l})$

0,977 = fator empírico para a conversão de amido em glicose através da hidrólise enzimática, obtido anteriormente por Schmidell e Fernandes (1976)

$0,9=$ fator estequiométrico para a conversão de amido em glicose

\subsubsection{Determinação da Atividade da Glicoamilase (A)}

Essa dosagem, da mesma maneira que a determinação da concentração de glicose (item 3.4.2) e da concentração de ART (item 3.4.3), era efetuada no filtrado da amostra, obtido quando da determinação da concentração celular (item 3.4.1), segundo técnica descrita por Park (1969), com algumas alterações (Facciotti, 1986 e Schmidell, 1986). 


\section{Reagentes}

a. Solução de tampão acético ( $\mathrm{pH}=4,2)$ : a $600 \mathrm{ml}$ de água destilada, adicionavam-se $57 \mathrm{ml}$ de ácido acético glacial (p.a.). Ajustava-se o pH em 4,2 com solução de $\mathrm{NaOH} 2 \mathrm{~N}$. Transferia-se a solução para um balão volumétrico de 1 litro e completava-se o volume com água destilada.

b. Solução de amido a 4 \%: pesavam-se $40 \mathrm{~g}$ de amido solúvel p.a. (E.Merck, Darmstadt) e adicionavam-se cerca de $40 \mathrm{ml}$ de água destilada. Agitava-se para homogeneizar transferia-se, quantitativamente para um béquer, adicionando-se $600 \mathrm{ml}$ de água destilada fervente. Fervia-se brandamente essa solução durante 2 minutos, resfriava-se e adicionavam-se $60 \mathrm{ml}$ da solução de tampão acético ( $\mathrm{pH}=4,2)$. Transferia-se para um balão volumétrico de 1 litro e completava-se o volume com água destilada.

\section{Procedimento para a dosagem}

Aproximadamente 15 minutos antes da tomada da amostra, colocava-se um balão volumétrico de $50 \mathrm{ml}$, contendo $25 \mathrm{ml}$ da solução de amido a $4 \%$ em um banho termostático (Gebruder Haake - Berlim, modelo Ultra-Thermostat), ajustado para $60^{\circ} \mathrm{C}$.

Uma vez colhida a amostra e efetuada a filtração (item 3.4.1), diluía-se o filtrado convenientemente e adicionava-se $1 \mathrm{ml}$ (com pipeta volumétrica) dessa amostra diluída ao balão contendo a solução de amido, procedendo-se a uma homogeneização. Após 60 minutos 
cronometrados, inativava-se a glicoamilase, colocando-se o balão volumétrico em um banho de água fervente, durante 5 minutos.

Após o resfriamento do balão, completava-se o volume com água destilada e procedia-se à dosagem da concentração de glicose contida no balão volumétrico (item 3.4.5).

Uma vez conhecida a concentração de glicose no balão volumétrico de $50 \mathrm{ml}$, calculava-se a massa de glicose liberada pela amiloglicosidase em 1 hora, e por mililitro de amostra diluída introduzida no balão, subtraindo-se da massa total de glicose, a parcela referente à glicose inicialmente presente na amostra, determinada segundo o procedimento no item 3.4.2.

Finalmente, levando-se em consideração a diluição efetuada no filtrado da amostra, calculava-se a atividade da glicoamilase, expressando-a em unidades (U) por volume de líquido fermentado (litro). A unidade de atividade (U/I) é definida como sendo a quantidade de enzima que, em 1 hora, libera 1 grama de glicose nas condições do ensaio padronizado (excesso de amido, temperatura de $60^{\circ} \mathrm{C}, \mathrm{pH}=4,2$ ).

Convém esclarecer que a "diluição conveniente" da amostra após filtração, era função da atividade da amiloglicosidase no caldo num dado instante de cultivo. Essa diluição era feita de forma que a concentração de glicose no volume de reação $(26 \mathrm{ml})$ não ultrapassasse $2 \mathrm{~g} / 1$ (Schmidell e Menezes, 1986). 


\subsubsection{Método da Glicose-oxidase para a Dosagem de Glicose}

O método de dosagem de glicose, implantado em um Technicon Auto-Analyser II, emprega a enzima glicose-oxidase (Glicose E-enzimática-Reactoclin) fabricada pela CELM - Cia. Equipadora de Laboratórios Modernos.

São empregados os seguintes reagentes:

. Solução de glicose-oxidase (maior ou igual a $1000 \mathrm{U} / \mathrm{ml}$ ) e peroxidase (maior ou igual a $120 \mathrm{U} / \mathrm{ml}$ )

. Reativo 4-AF: solução de 4-aminofenazona (25 mmol//)

. Reativo fenol: solução de fenol (55 mmol/l)

Em um balão volumétrico de $1000 \mathrm{ml}$, coloca-se aproximadamente $500 \mathrm{ml}$ de água destilada, $50 \mathrm{ml}$ de reativo 4-AF, 50 $\mathrm{ml}$ de reativo fenol e $3 \mathrm{ml}$ da solução de glicose-oxidase e peroxidase. Completa-se o volume com água destilada.

Na execução do método, a amostra é inicialmente dialisada, com a finalidade de eliminar macromoléculas que poderiam interferir na leitura final.

A glicose que passa pela membrana é oxidada pela glicose-oxidase a ácido glicônico e peróxido de hidrogênio. 0 peróxido de hidrogênio, em presença de peroxidase permite a reação do fenol com a 4-aminofenazona, dando lugar à formação de um cromógeno vermelho, o 4-(p-benzoquinona-monoimino) fenazona.

A concentração de glicose na amostra dialisada é obtida portanto, pela medida do aumento do teor do referido cromógeno, em um colorímetro a $340 \mathrm{~nm}$. 
Para a calibração do método no Technicon Auto-Analyser II, são utilizadas soluções padronizadas de glicose p.a. (E.Merck, Darmstadt) nas seguintes concentrações, em gramas por litro: 0,$2 ; 0,4 ; 0,6 ; 0,8$ e 1,0. 


\subsection{Conceitos Utilizados na Análise dos Resultados}

Neste item será descrita a metodologia utilizada para a análise dos resultados obtidos. Esta abordagem teórica está descrita numa série de livros (Aiba et al., 1973, Pirt, 1975 e Wang et al., 1979), sendo aqui repetida a fim de facilitar o acompanhamento da discussão.

Convém também lembrar que, em termos de produto, interessa neste trabalho o aparecimento de glicoamilase no caldo fermentado. Assim sendo, o produto será caracterizado, como usualmente para enzimas, por sua atividade enzimática, em unidades de atividade enzimática por unidade de volume de meio, determinadas conforme item 3.4.4, e não em massa por unidade de volume de meio.

\subsubsection{Velocidades Específicas}

Como se sabe, ao se dispor de curvas de variação da concentração celular (X) e da atividade enzimática (A) em função do tempo (t), pode-se definir as velocidades apresentadas nas Equações (3.2) e (3.3).

$$
\begin{aligned}
& \mathrm{v}_{\mathrm{X}}=\frac{\mathrm{dX}}{\mathrm{-dt}}=\text { velocidade de crescimento celular }(\mathrm{g} / \mathrm{h} / \mathrm{h}) \\
& \mathrm{vA}=\frac{\mathrm{dA}}{\mathrm{dt}}=\text { velocidade de produção de glicoamilase }(\mathrm{U} / \mathrm{h} / \mathrm{h})
\end{aligned}
$$

Estas velocidades, além de serem evidentemente influenciadas pelas condições de cultivo, estão na dependência também da 
concentração celular. Justamente por este motivo, quando se pretende comparar velocidades sem a interferência da quantidade de células presentes, definem-se as velocidades especificas $\mu$ e $\mu \mathrm{A}$, segundo as Equações (3.4) e (3.5).

$$
\begin{aligned}
& \mu=\frac{1}{\mathrm{X}} \cdot \frac{\mathrm{dX}}{\mathrm{dt}}=\begin{array}{l}
\text { velocidade específica de } \\
\text { crescimento celular }\left(\mathrm{h}^{-1}\right)
\end{array} \\
& \mu \mathrm{A}=\frac{1}{\mathrm{X}} \cdot \frac{\mathrm{dA}}{\mathrm{dt}}=\begin{array}{l}
\text { velocidade especifica de } \\
\text { produção de enzima }(\mathrm{U} / \mathrm{g} / \mathrm{h})
\end{array}
\end{aligned}
$$

Para todos os ensaios, foram traçadas curvas médias de $X=f(t)$ e $\mathrm{A}=\mathrm{f}(\mathrm{t})$ a partir dos resultados experimentais. Destas, tomaram-se os valores de $\mathrm{X}$ e de $\mathrm{A}$ utilizados na determinação das velocidades específicas de crescimento $(\mu)$ e produção de glicoamilase $(\mu \mathrm{A})$ em função do tempo de cultivo, através do método de cálculo de derivadas proposto por Le Duy e Zajic (1973), adaptado e implantado em microcomputador. Apesar de terem sido tomados e calculados a cada 0,5 e 1 hora (em ensaios a $S_{0}=20$ e $40 \mathrm{~g} / 1$, respectivamente), estes valores serão apresentados, nas tabelas do apêndice A-1, a cada 1 e 2 horas apenas.

Um rearranjo da Equação (3.4) permite escrevê-la na forma da Equação (3.6). Dessa forma, pode-se visualizar graficamente a velocidade específica de crescimento a cada instante, como sendo a tangente da curva de $\ln X=f(t)$.

$$
\mu=\frac{d(\ln X)}{d t}=\quad \begin{aligned}
& \text { velocidade específica de } \\
& \text { crescimento celular }\left(h^{-1}\right)
\end{aligned}
$$


Ao se analisar uma curva típica de crescimento celular, é possível reconhecer etapas distintas, como são exemplo a fase de indução, logarítmica e de declínio. Em particular, na fase logarítmica ou exponencial, o valor de $\mu$ é tido como máximo e constante, o que permite integrar a Equação (3.4), obtendo-se a Equação (3.7):

$$
\log X=\log X_{0}+\frac{\mu_{\text {máx }}}{2,303} \cdot\left(t-t_{0}\right)
$$

onde:

$t_{0}=$ instante de início da fase exponencial (h)

$\mathrm{X}_{\mathrm{O}}=$ concentração celular no instante $\mathrm{t}_{\mathrm{o}}(\mathrm{g} / \mathrm{l})$

$\mathrm{X}=$ concentração celular no instante $\mathrm{t}(\mathrm{g} / \mathrm{l})$

$\mu_{\text {máx }}=$ velocidade específica máxima de crescimento celular (constante) $\left(\mathrm{h}^{-1}\right)$

Através da Equação (3.7) é possível distinguir a fase exponencial em um gráfico semilogarítmico (mono-log) de $\mathrm{X}$ em função do tempo, pelo alinhamento dos pontos nesta fase, podendo-se obter, portanto, o valor de $\mu_{\text {máx }}$ pelo coeficiente angular da reta ajustada.

\subsubsection{Fatores de Conversão e Produtividades}

Em processos fermentativos, frequentemente se analisam também, fatores de conversão e produtividades. Esses parâmetros 
foram calculados para cada ensaio, definidos pelas Equações (3.8) a (3.11).

. Fator de conversão substrato a células $(\mathrm{g} / \mathrm{g})$

$\mathrm{YX} / \mathrm{S}=\frac{\mathrm{Xm}-\mathrm{Xo}}{\mathrm{tX}}$

. Fator de conversão substrato a enzima (U/g)

$\mathrm{YA} / \mathrm{S}=\frac{\mathrm{Am}-\mathrm{Ao}}{\mathrm{tA}}$

. Produtividade em células $(\mathrm{g} / \mathrm{l} / \mathrm{h})$

$\mathrm{PX}=\frac{\mathrm{Xm}-\mathrm{Xo}}{\left(\mathrm{S}_{\mathrm{O}} \text { ou } \mathrm{St}\right)}$

- Produtividade em enzima, ou em relação a atividade enzimática $(\mathrm{U} / \mathrm{l} / \mathrm{h})$

$P A=\frac{A m-A o}{\left(S_{0} \text { ou St }\right)}$

onde:

$\mathrm{Xm}=$ concentração celular máxima (no instante $\mathrm{tX})(\mathrm{g} / \mathrm{l})$

Xo $=$ concentração celular inicial $(\mathrm{g} / \mathrm{l})$

So $=$ concentração inicial de ART $(g / 1)$

St $=\quad$ concentração "total" de ART (soma das quantidades inicial e alimentada, dividida pelo volume final) $(\mathrm{g} / \mathrm{l})$

$\mathrm{Am}=$ atividade enzimática máxima (no instante tA) (U/1)

$\mathrm{Ao}=$ atividade enzimática inicial (U/1)

$\mathrm{tA}=\quad$ instante de máxima atividade enzimática (h)

$\mathrm{tX}=\quad$ instante de máxima concentração celular (h) 
Os valores de $\mathrm{X}, \mathrm{A}$, $\mathrm{S}$ e t considerados para os cálculos, bem como os parâmetros calculados, são apresentados no Capítulo 4 (Resultados e Discussão) a medida que se tornam necessários para a discussão.

Com relação ao cálculo destes parâmetros, convém ainda observar que:

- No cálculo dos fatores de conversão, utilizou-se $S_{0}$ para os ensaios descontínuos e St para os descontínuos alimentados.

- No cálculo das produtividades, de forma mais rigorosa, os denominadores deveriam ser o instante final subtraído do instante inicial, porém este é nulo em todos os cálculos.

- Alguns valores utilizados nos cálculos foram tomados das curvas médias de $X, S$ e A como função do tempo, traçadas a partir dos valores experimentais de cada ensaio, bem como do conhecimento adquirido de outros ensaios semelhantes. Isto decorre da imprecisão ou da falta de algumas medidas.

- O instante em que se atinge Xm normalmente coincide com o de fim da fonte de carbono $(S=0 \mathrm{~g} / \mathrm{l})$, visto que há relação entre 0 crescimento e o consumo de substrato. Apesar disto, há casos em que não ocorre esta coincidência claramente. 


\section{RESULTADOS E DISCUSSÃO}

Neste capítulo, serão apresentadas as discussões relativas a cada ensaio ou conjunto de ensaios, à medida em que se apresentam as figuras representativas dos seus resultados. No Anexo A-1, são apresentadas todas as tabelas com as concentrações de ART (S), de glicose $(G)$, de células $(X)$ e atividade enzimática $(A)$, bem como as velocidades especificas de crescimento $(\mu)$ e produção de enzima $(\mu A)$ e os valores de $\mathrm{X}$ e A considerados para seus cálculos.

Dessa forma, espera-se facilitar com as figuras, a compreensão das discussões, sem contudo sobrecarregar este capítulo com uma série de informações em tabelas, já representadas graficamente.

Inicialmente, se apresentam algumas considerações preliminares (item 4.1), visando facilitar as discussões a respeito dos ensaios.

Em seguida (item 4.2), uma análise dos vários ensaios descontínuos, que podem ser entre si considerados repetições. Dessa forma, busca-se ter uma noção da variabilidade possivel dos resultados. Tais ensaios, como mencionado no item 3.3, foram realizados em paralelo aos descontínuos alimentados, como padrão para comparação.

No item seguinte (4.3), apresentam-se os ensaios descontínuos alimentados (fed-batch) à concentração inicial de ART $\left(S_{0}\right)$ de $20 \mathrm{~g} /$, divididos em dois sub-itens. Aqui no texto, para classificação do ensaio, será usado o termo $S_{0}$, no lugar de $S t$, formalmente mais correto ao se tratar de ensaios descontínuos alimentados, com o intuito apenas de facilitar a comparação com os ensaios descontínuos. 
Posteriormente, há uma análise dos ensaios descontínuos alimentados a $S_{0}=40 \mathrm{~g} /$ (item 4.4), tendo como base de comparação as discussões anteriores.

Por último, se apresenta uma discussão final (item 4.5), condensando o exposto anteriormente.

\subsection{Considerações preliminares}

\subsubsection{Escalas dos Gráficos}

Para facilitar a análise dos resultados, tentou-se na formatação final dos vários gráficos representativos dos ensaios (Figuras 4.2 a 4.7 e 4.9 a 4.18), padronizar as escalas tanto quanto possível. As escalas das ordenadas se apresentam como múltiplos de 12, adequando-se basicamente a $S_{0}$ e tipo de processo e as abcissas iguais a 27 ou 37 horas.

Convém salientar que para acomodar todos os resultados experimentais de um dado ensaio em apenas uma figura com 2 eixos de ordenada, apresenta-se a unidade de atividade enzimática em 100 ou 200 U/, dependendo da relação Xm e Am em cada ensaio. 


\subsubsection{Volume de Reação}

Nos ensaios descontínuos alimentados, o volume de reação (volume ocupado no reator) é considerado constante ao longo do ensaio. Essa aproximação deriva da expectativa de que não sejam tão pronunciadas as flutuações no volume total com o decorrer do ensaio.

Vários fatores influem no volume reacional ao longo do ensaio, principalmente as adições de meio de alimentação, solução desoda ou ácido e subtrações de amostras e desprezados (volumes mortos). 0 xarope de alimentação, como visto no item 3.2.2, é preparado concentrado, de modo que se utiliza o menor volume possível para se acrescentar 180 ou 380 gART. Assim, nos ensaios descontínuos alimentados, tem-se a adição de cerca de $600 \mathrm{ml}(\mathrm{St}=20 \mathrm{~g} / \mathrm{l})$ ou $1200 \mathrm{ml}$ $(\mathrm{St}=40 \mathrm{~g} / \mathrm{l})$ de xarope ao longo das várias horas de alimentação. Esse valor, em relação ao volume total de reação pode ser desprezado, em especial porque há flutuações ao longo do ensaio.

Para se fazer uma previsão da variação de volume ao longo se um cultivo, calculou-se um balanço de matéria (expresso em volume), de um determinado ensaio como exemplo (ensaio F21), levando em conta todas as entradas e saídas mensuráveis, e o resultado pode ser visto através da Tabela 4.1 e Figura 4.1. Como referência entre o calculado (Vcal) e o experimental (real), tem-se apenas o volume ao final do ensaio. Assim, calculou-se também um volume ao longo do ensaio (Vcor) corrigindo o calculado pela adição de parcelas, de modo a atingir ao final do cultivo o valor real. Observa-se que o volume final calculado diferia mais que o esperado em relação ao medido após o final do 
ensaio $(730 \mathrm{ml})$, porém mantendo-se abaixo de $10 \%$ em relação ao volume inicial. Por outro lado, observa-se também que durante o período em que ocorre alimentação do sistema, o volume praticamente não se altera, o que permite ignorar a variação de volume para efeito de cálculo de concentrações em ensaios descontínuos alimentados.

Essa diferença entre o valor final do volume calculado (Vcal) e o volume final medido deve-se às alterações no volume que não foram computadas em Vcal. Apesar do equipamento possuir um condensador para os gases efluentes do reator, não se consegue evitar completamente a perda de água na forma de vapor, e considerando-se a duração do ensaio e a vazão de ar, essa quantidade não é desprezível. Em um teste com água, observou-se a perda de cerca de $600 \mathrm{~g}$ de água em reator semelhante, ao longo de 40 horas de cultivo. Outro fator não contabilizado na medida do volume final, é o volume de micélio que permanece preso na lateral do fermentador após o fim do ensaio, tendo atingido, em um ensaio em que foi medido, o volume de $500 \mathrm{ml}$. 


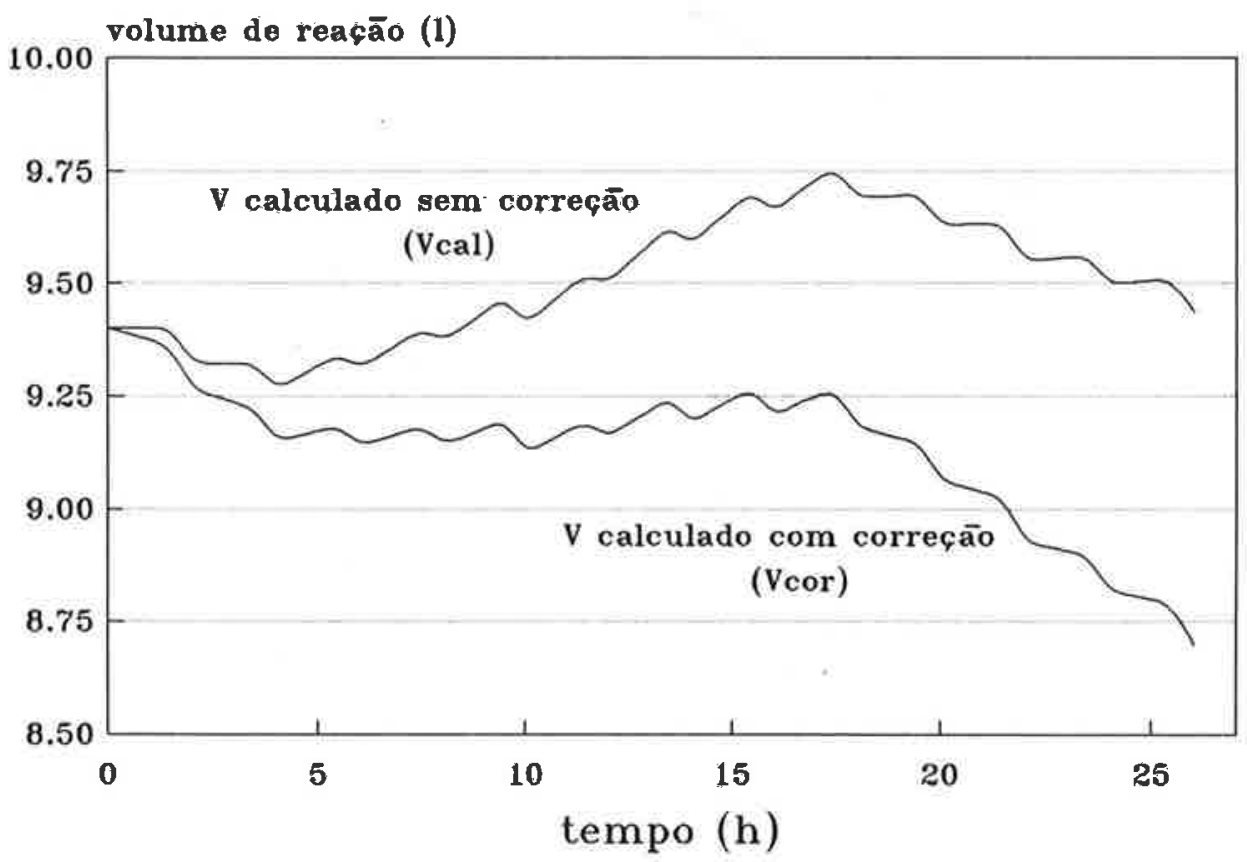

Figura 4.1 Volume de reação calculado sem (Vcal) e com (Vcor) correção ao longo do tempo de cultivo no ensaio F21 (fed-batch; $S_{0}=20 \mathrm{~g} /$; fs $=13,3 \mathrm{gART} / \mathrm{h}$ ) 
Tabela 4.1 Volume calculado sem correção (Vcal), calculado com correção (Vcor), desprezado na retirada de amostra (Vdes), de amostra (Vamo), alimentado no intervalo de 1 hora (Vali), adicionado de hidróxido de sódio $(\mathrm{VNaOH})$ ou ácido clorídrico (VHCl) para manutenção do $\mathrm{pH}$ a cada hora de cultivo no ensaio F21.

\begin{tabular}{|c|c|c|c|c|c|c|c|}
\hline $\begin{array}{l}\text { t } \\
\text { (h) }\end{array}$ & 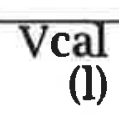 & $\begin{array}{l}\text { Vcor } \\
\text { (l) }\end{array}$ & $\begin{array}{l}\text { Vdes } \\
\text { (ml) }\end{array}$ & $\begin{array}{r}\text { Vamo } \\
\text { (ml) }\end{array}$ & $\begin{array}{l}\text { Vali } \\
\text { (ml) }\end{array}$ & $\begin{array}{l}\mathrm{VNaOH}_{(\mathrm{ml})}\end{array}$ & $\begin{array}{r}\mathrm{VHCl} \\
\text { (ml) }\end{array}$ \\
\hline 0 & 9,40 & 9,40 & 8 & 57,51 & & 0,0 & 0,0 \\
\hline 1 & 9,40 & 9,37 & & & & 0,0 & 0,0 \\
\hline 2 & 9,32 & 9,27 & 23 & 55,32 & & 0,0 & 0,0 \\
\hline 3 & 9,32 & 9,24 & 20 & $400 ?$ & & $\begin{array}{l}0,0 \\
20\end{array}$ & 0,0 \\
\hline $\begin{array}{l}4 \\
5\end{array}$ & $\begin{array}{l}9,26 \\
9,32\end{array}$ & $\begin{array}{l}9,15 \\
9,17\end{array}$ & 20 & 40,92 & $\begin{array}{l}48,22 \\
48,22\end{array}$ & $\begin{array}{l}3,0 \\
3,4\end{array}$ & $\begin{array}{l}0,0 \\
0,0\end{array}$ \\
\hline 6 & 9,31 & 9,14 & 17 & 39,71 & 48,22 & 4,6 & 0,0 \\
\hline 7 & 9,37 & 9,17 & & 30045 & 48,22 & 8,4 & 0,0 \\
\hline $\begin{array}{l}8 \\
9\end{array}$ & $\begin{array}{l}9,37 \\
943\end{array}$ & $\begin{array}{l}9,14 \\
9,18\end{array}$ & 16 & 39,945 & $\begin{array}{l}48,22 \\
48,22\end{array}$ & $\begin{array}{l}10,6 \\
140\end{array}$ & $\begin{array}{l}0,0 \\
0.0\end{array}$ \\
\hline 10 & 9,41 & 9,12 & 26 & 78,38 & 48,22 & 28,1 & 0,0 \\
\hline 11 & 9,48 & 9,17 & & & 48,22 & 31,1 & 0,0 \\
\hline 12 & 9,50 & 9,16 & 22 & 47,72 & 48,22 & 34,7 & 0,0 \\
\hline 13 & $\begin{array}{l}9,58 \\
0,50\end{array}$ & 9,22 & 21 & 6056 & 48,22 & 38,4 & 0,0 \\
\hline 15 & 9,67 & 9,24 & & & 48,22 & 35,1 & 0,0 \\
\hline 16 & 9,66 & 9,20 & 26 & 65,27 & 48,22 & 32,2 & 0,0 \\
\hline 17 & 9,73 & 9,25 & & & 48,22 & 25,7 & 0 \\
\hline 18 & 9,69 & 9,18 & 26 & 55,22 & & 6,7 & 12,8 \\
\hline 19 & 9,70 & 9,16 & & & & 0,0 & 3,1 \\
\hline 20 & 9,63 & 9,06 & 25 & 49,86 & & 0,0 & 8,1 \\
\hline 21 & $\begin{array}{l}9,63 \\
0,55\end{array}$ & $\begin{array}{l}9,04 \\
8,02\end{array}$ & 35 & & & 0,0 & 4,2 \\
\hline 23 & $\begin{array}{l}9,55 \\
9,56\end{array}$ & 8,91 & $3 J$ & 59,47 & & 0 & $\begin{array}{r}8,2 \\
108\end{array}$ \\
\hline 24 & 9,50 & 8,82 & 27 & 46,12 & & 0,0 & 11,5 \\
\hline 25 & 9,51 & 8,80 & & & & 0,0 & 10,6 \\
\hline 26 & 9,43 & 8,70 & 31 & 50,68 & & 0,0 & 10,5 \\
\hline
\end{tabular}


4.2 Descrição dos resultados de um ensaio descontínuo típico e sua variabilidade

4.2.1 Ensaios a $S_{0}$ de $20 \mathrm{~g} / \mathrm{A}$ B21, B22, B23 e B24

Como base para comparação com os ensaios descontínuos alimentados, serão antes apresentados os ensaios descontínuos; inicialmente os ensaios com concentração inicial de ART $\left(S_{0}\right)$ de 20 g/l, conforme Figuras 4.2 a 4.5.

Nos ensaios descontínuos, toda fonte de carbono é oferecida logo no início, que é quando se tem o maior valor de S. Na preparação do meio, coloca-se xarope de farinha de mandioca em quantidade suficiente para se ter $S_{0}=20 \mathrm{~g} / \mathrm{e}$, devido a flutuações que serão explicadas adiante, obtém-se $S_{0}$ variando entre 20,7 e 24,1 g/l.

Assim a curva de $S$ inicia-se tipicamente em torno de $22 \mathrm{~g} / \mathrm{l}$, mantém-se alta durante a fase lag (adaptação) do crescimento (até cerca de 4 horas) e decai rapidamente, atingindo $0 \mathrm{~g} / \mathrm{l}$ com cerca de $20 \mathrm{~h}$ de ensaio. Já a glicose (G) sofre 2 efeitos opostos: produção, devido à hidrólise dos polissacarídeos presentes, e consumo, devido ao metabolismo microbiano. A hidrólise pode ser observada pela diminuição na quantidade de polissacarídeos representado pelo espaço entre as curvas $S(t)$ e $G(t)$. 

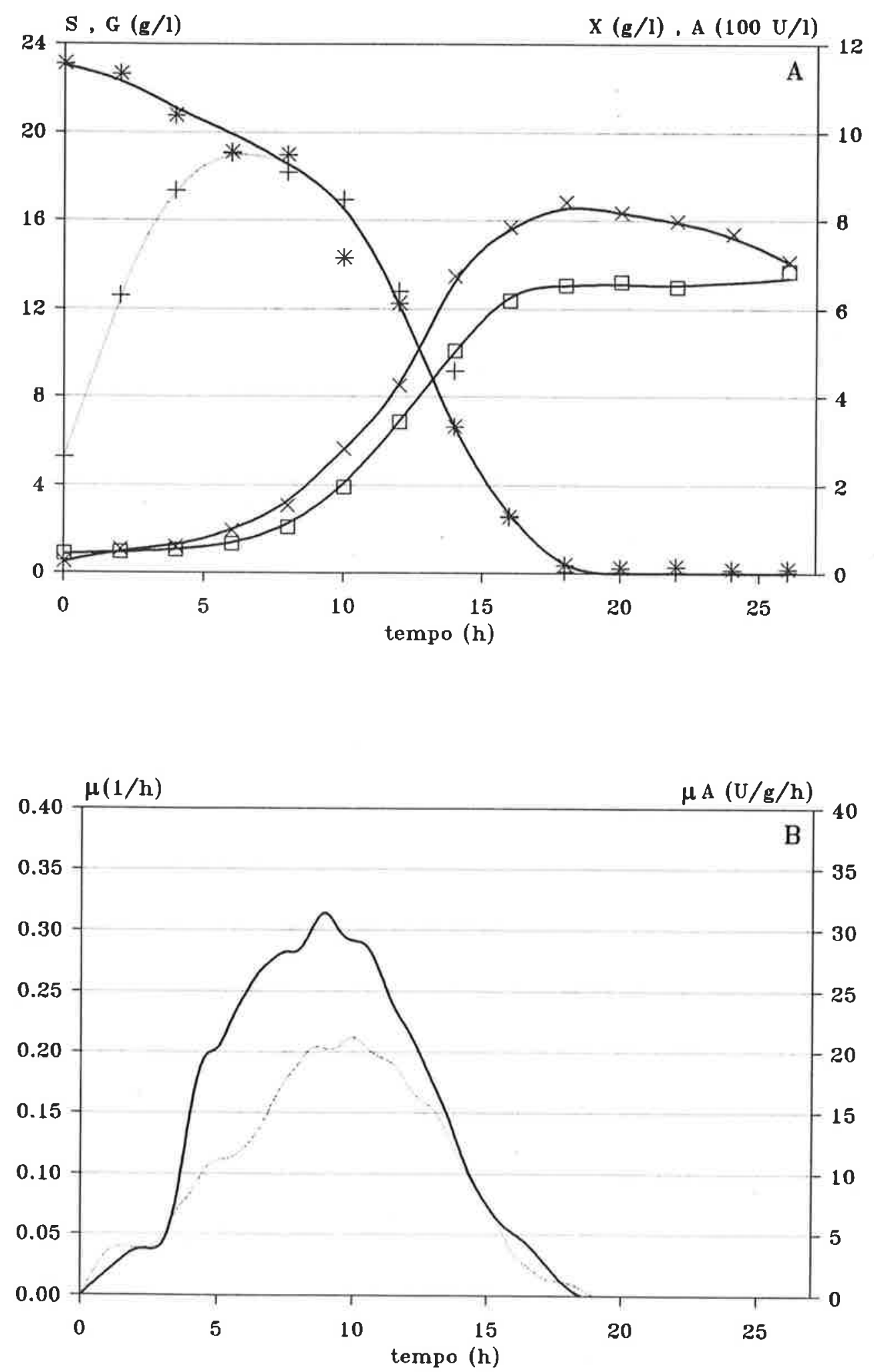

Figura 4.2 Resultados obtidos no ensaio B21 ( $\left.1^{\circ} \mathrm{batch}, 20 \mathrm{~g} / \mathrm{l}\right)$.

A) Concentração de ART $(S)\left({ }^{*}\right)$, glicose $(G)(+)$, células $(X)(X)$ e atividade enzimática (A) (ם)

B) Velocidades específicas de crescimento (u) (-) e produção de enzima ( $\mu \mathrm{A})(---)$ 

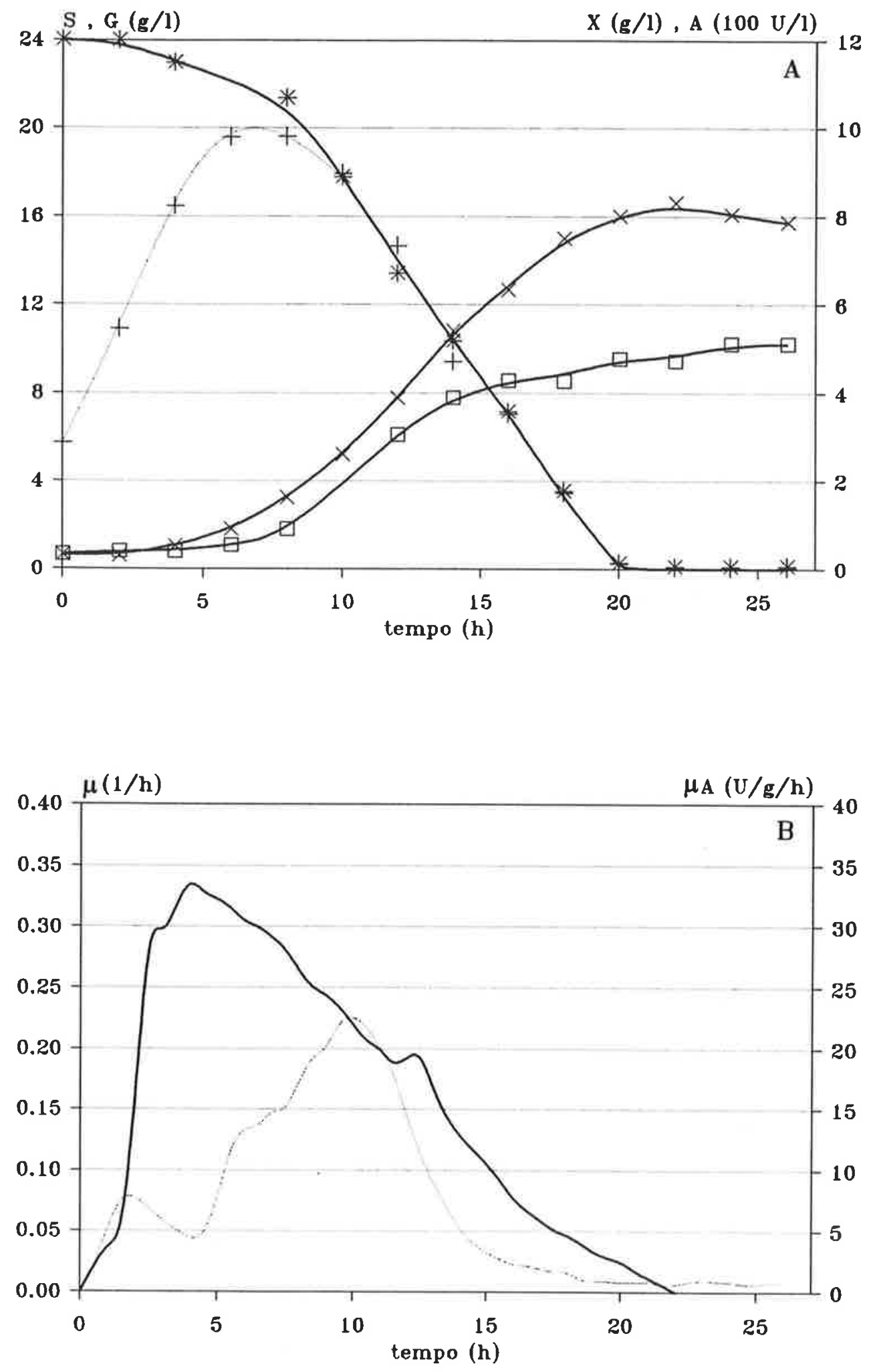

Figura 4.3 Resultados obtidos no ensaio B22 ( $2^{\circ}$ batch, $20 \mathrm{~g} / 1$ ).

A) Concentração de ART $(S)(*)$, glicose $(G)(+)$, células $(X)(X)$ e atividade enzimática (A) ( $($ )

B) Velocidades específicas de crescimento ( $\mu)(-)$ e produção de enzima ( $\mu$ A) (- - -) 

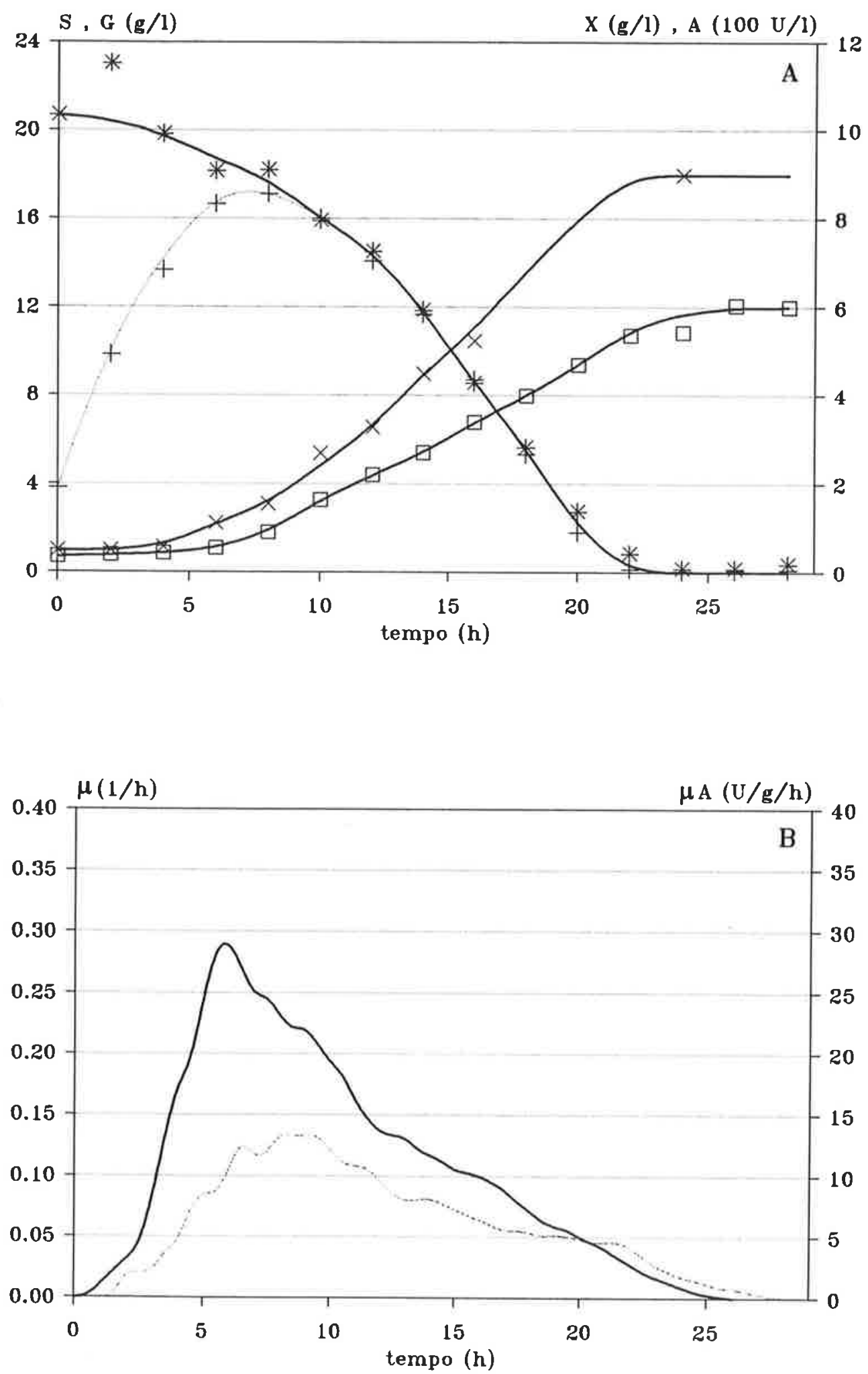

Figura 4.4 Resultados obtidos no ensaio B23 ( $3^{\circ}$ batch, $20 \mathrm{~g} / \mathrm{l}$ ).

A) Concentração de ART (S) $\left(^{*}\right)$, glicose $(G)(+)$, células $(X)(X)$ e atividade enzimática (A) (ID)

B) Velocidades especificas de crescimento $(\mu)(\longrightarrow$ e produção de enzima ( $\mu \mathrm{A})(-\cdot-)$ 

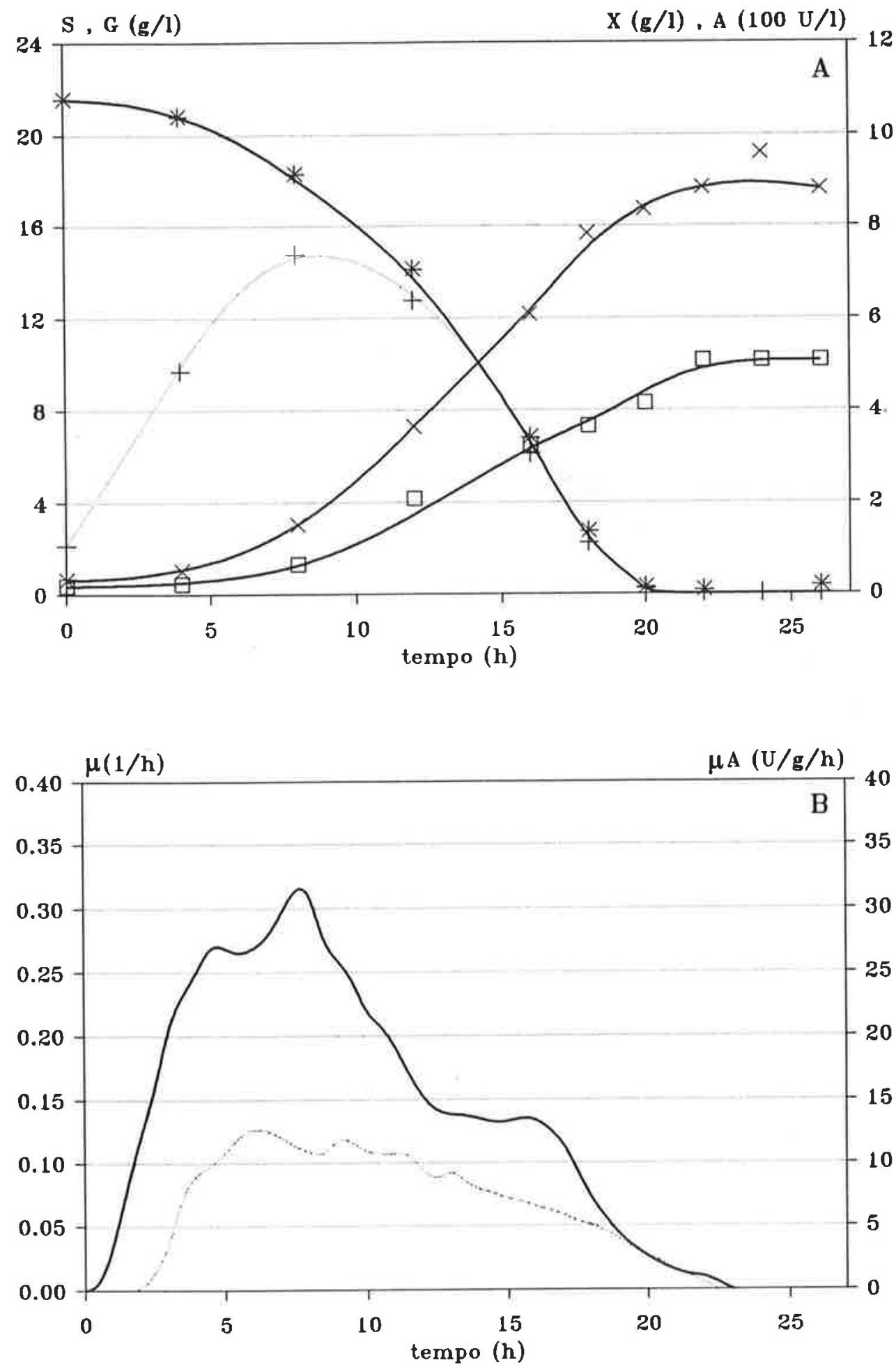

Figura 4.5 Resultados obtidos no ensaio B24 ( $\left.4^{\circ} \mathrm{batch}, 20 \mathrm{~g} / \mathrm{l}\right)$.

A) Concentração de ART $(S)\left({ }^{*}\right)$, glicose $(G)(+)$, células $(X)(X)$ e atividade enzimática (A) (I)

B) Velocidades específicas de crescimento $(\mu)(-)$ e produção de enzima ( $\mu \mathrm{A})\left(-\right.$ - - $^{-}$ 
O substrato $\mathrm{S}$, sendo a soma da glicose e polissacarídeos, representa a quantidade total de substrato apresentado ao microrganismo, independente de qual é a fração que já está hidrolisada. Por este motivo que $S$ é considerado como substrato da célula, e não a glicose, que é enfim a substância que é assimilada pela célula como fonte de carbono e energia.

Ao longo do tempo de cultivo, a concentração de glicose aumenta no início, pois há uma certa hidrólise e o consumo pela célula ainda é pequeno, atinge um máximo em cerca de 6 a 8 horas e começa a diminuir, igualando-se então a curva de $S$ (entre 8 e 10 horas), quando não mais se detecta polissacarídeos no fermentador.

Nesse instante, pode-se dizer que não mais existe indutor à sintese de glicoamilase e o repressor (glicose) apresenta-se em concentração máxima.

A curva do crescimento microbiano $X(t)$ comporta-se semelhantemente à maioria dos processos descontínuos conhecidos, isto é, após uma fase de adaptação às novas condições (diferentes das do incubador), onde a variação da concentração celular é desprezível, inicia-se um aumento exponencial, durante o qual se tem velocidade específica máxima de crescimento ( $\mu_{\text {máx }}$ ), normalmente entre 4 e 9 horas de cultivo. Segue-se então uma diminuição de $\mu$ até se obter Xm, de cerca de 8,5 g/ 1 , geralmente em torno de $20 \mathrm{~h}$. A partir dai, na maioria dos ensaios se observa uma queda no valor de $\mathrm{X}$, possivelmente devido à lise celular, consequência da liberação de enzimas líticas pelo próprio microrganismo. As Tabelas 4.2 e 4.3 apresentam os valores dos fatores de conversão e produtividades para esses quatro ensaios. 
Tabela 4.2 Grandezas usadas no cálculo de fatores de conversão e produtividades para os ensaios B21, B22, B23 e B24.

\begin{tabular}{|cccccccc|}
\hline Ensaio & $\begin{array}{c}\mathrm{S}_{\mathrm{o}} / \mathrm{St} \\
(\mathrm{g} / \mathrm{l})\end{array}$ & $\begin{array}{c}\mathrm{tX} \\
(\mathrm{h})\end{array}$ & $\begin{array}{c}\mathrm{Xo} \\
(\mathrm{g} / \mathrm{l})\end{array}$ & $\begin{array}{c}\mathrm{Xm} \\
(\mathrm{g} / \mathrm{1})\end{array}$ & $\begin{array}{c}\mathrm{tA} \\
(\mathrm{h})\end{array}$ & $\begin{array}{c}\mathrm{Ao} \\
(\mathrm{U} / \mathrm{l})\end{array}$ & $\begin{array}{c}\mathrm{Am} \\
(\mathrm{U} / \mathrm{l})\end{array}$ \\
$\mathrm{B} 21$ & 23,1 & 18 & 0,25 & $\mathbf{8 , 4 2}$ & 18 & 42 & 653 \\
$\mathrm{~B} 22$ & 24,1 & 20 & 0,32 & 8,01 & 24 & 34 & 512 \\
$\mathrm{~B} 23$ & 20,7 & 22 & 0,48 & 8,60 & 24 & 34 & 580 \\
B24 & 21,5 & 22 & 0,30 & 8,83 & 22 & 18 & 507 \\
\hline
\end{tabular}

Tabela 4.3 Grandezas calculadas: fatores de conversão e produtividades para os ensaios B21, B22, B23 e B24.

\begin{tabular}{|ccccc|}
\hline Ensaio & $\begin{array}{c}\text { YX/S } \\
(\mathrm{g} / \mathrm{g})\end{array}$ & $\begin{array}{c}\mathrm{PX} \\
(\mathrm{g} / \mathrm{l} / \mathrm{h})\end{array}$ & $\begin{array}{c}\mathrm{YA} / \mathrm{S} \\
(\mathrm{U} / \mathrm{g})\end{array}$ & $\begin{array}{c}\mathrm{PA} \\
(\mathrm{U} / \mathrm{h} / \mathrm{h})\end{array}$ \\
B21 & 0,35 & 0,45 & 26 & 33 \\
B22 & 0,32 & 0,38 & 20 & 19 \\
B23 & 0,39 & 0,37 & 26 & 23 \\
B24 & 0,40 & 0,39 & 23 & 22 \\
\hline
\end{tabular}

O produto da fermentação neste trabalho, a enzima glicoamilase, apresenta normalmente uma cinética classificada por Gaden (1959) como associada ao crescimento, isto é, a velocidade específica de formação de produto é relativamente proporcional à velocidade específica de crescimento. Isto significa que a curva $A(t)$ apresentar-se-á na forma sigmóide, semelhantemente a $\mathrm{X}(\mathrm{t})$, também com fases de adaptação, exponencial, estacionária e de declínio. $O$ valor da atividade enzimática máxima $(\mathrm{Am})$ varia bastante, entre 500 e 650 U/, dependendo do ensaio. 


\subsubsection{Ensaios a $S_{0}$ de $40 \mathrm{~g} / \mathrm{L}$ B41 e B42}

Nos ensaios descontínuos alimentados com $\mathrm{S}_{0}=40 \mathrm{~g} / 1$, B41 e B42, o comportamento das variáveis $S, G, X$ e A são muito semelhantes aos $\operatorname{com} S_{0}=20 \mathrm{~g} /$, conforme se observa pelas Figuras 4.6 e 4.7. A forma das curvas são idênticas e variam apenas os valores máximos, bem como o instante em que ocorre Xm e Am. O substrato parte de um valor mais alto e portanto chega ao valor zero num instante posterior, em torno de 25 horas de cultivo. A glicose atinge um máximo de cerca de $28 \mathrm{~g} / 1$ e se encontra com a curva de $S$ mais tardiamente, em torno de $12 \mathrm{~h}$. Xo e Ao mantém-se iguais, pois o preparo e a fração de inóculo não são alterados. Os valores finais de $\mathrm{X}$ e $\mathrm{A}$ alteram-se, porém não proporcionalmente à variação de $S_{0}$. A concentração celular atinge valores em torno de $12 \mathrm{~g} / \mathrm{h}$ nos ensaios a $S_{0}=40 \mathrm{~g} / \mathrm{l}$, o que indica que o fator de conversão substrato a célula com o aumento de $S_{0}$ de 20 a 40 $\mathrm{g} /$, decai de em média 0,37 para 0,27 , enquanto que $\mathrm{PX}$ sobe de 0,38 para $0,45 \mathrm{~g} / \mathrm{h} / \mathrm{h}$ com $\mathrm{o}$ aumento de $S_{0}$, conforme se observa pelas Tabelas 4.4 e 4.5 .

Por outro lado, a produção de enzima aumenta de modo mais pronunciado com o aumento de $S_{\mathbf{0}}$. A máxima atividade enzimática (Am) nos ensaios a $S_{0}=40 \mathrm{~g} / \mathrm{l}$ situa-se em torno de $2100 \mathrm{U} / \mathrm{l}$, o que implica em duplicar o valor de $\mathrm{YA} / \mathrm{S}$, chegando a $48 \mathrm{U} / \mathrm{g}$ em relação ao $\mathrm{YA} / \mathrm{S}$ de $23 \mathrm{U} / \mathrm{g}$ para $S_{0}=20 \mathrm{~g} /$. Da mesma forma, a produtividade em enzima (PA) triplica de $25 \mathrm{U} / \mathrm{h} / \mathrm{h}$ com $\mathrm{S}_{0}=20 \mathrm{~g} / \mathrm{A}$ para 74 nesta concentração de ART superior. Essas análises iniciais deverão ser consideradas, quando da discussão dos ensaios descontínuos 
alimentados em relação a seus paralelos descontínuos, nos dois diferentes valores de $S_{0}$ estudados.

Tabela 4.4 Grandezas usadas no cálculo de fatores de conversão e produtividades para os ensaios B41 e B42.

\begin{tabular}{|cccccccc|}
\hline Ensaio & $\begin{array}{c}\mathrm{S}_{\mathrm{o}} / \mathrm{St} \\
(\mathrm{g} / \mathrm{l})\end{array}$ & $\begin{array}{c}\mathrm{tX} \\
(\mathrm{h})\end{array}$ & $\begin{array}{c}\mathrm{Xo} \\
(\mathrm{g} / \mathrm{l})\end{array}$ & $\begin{array}{c}\mathrm{Xm} \\
(\mathrm{g} / \mathrm{l})\end{array}$ & $\begin{array}{c}\mathrm{tA} \\
(\mathrm{h})\end{array}$ & $\begin{array}{c}\text { Ao } \\
(\mathrm{U} / \mathrm{l})\end{array}$ & $\begin{array}{c}\mathrm{Am} \\
(\mathrm{U} / \mathrm{l})\end{array}$ \\
$\mathrm{B} 41$ & 44,7 & 24 & 0,29 & 12,27 & 27 & 20 & 2134 \\
$\mathrm{~B} 42$ & 42,3 & 30 & 0,27 & 12,20 & 30 & 23 & 2088 \\
\hline
\end{tabular}

Tabela 4.5 Grandezas calculadas: fatores de conversão e produtividades para os ensaios B41 e B42.

\begin{tabular}{|rcccc|}
\hline Ensaio & $\begin{array}{c}\text { YX/S } \\
(\mathrm{g} / \mathrm{g})\end{array}$ & $\begin{array}{c}\mathrm{PX} \\
(\mathrm{g} / \mathrm{h} / \mathrm{h})\end{array}$ & $\begin{array}{c}\mathrm{YA} / \mathrm{S} \\
(\mathrm{U} / \mathrm{g})\end{array}$ & $\begin{array}{c}\mathrm{PA} \\
(\mathrm{U} / \mathrm{h} / \mathrm{h})\end{array}$ \\
$\mathrm{B} 41$ & 0,27 & 0,50 & 47 & 78 \\
B42 & 0,28 & 0,40 & 49 & 68 \\
\hline
\end{tabular}



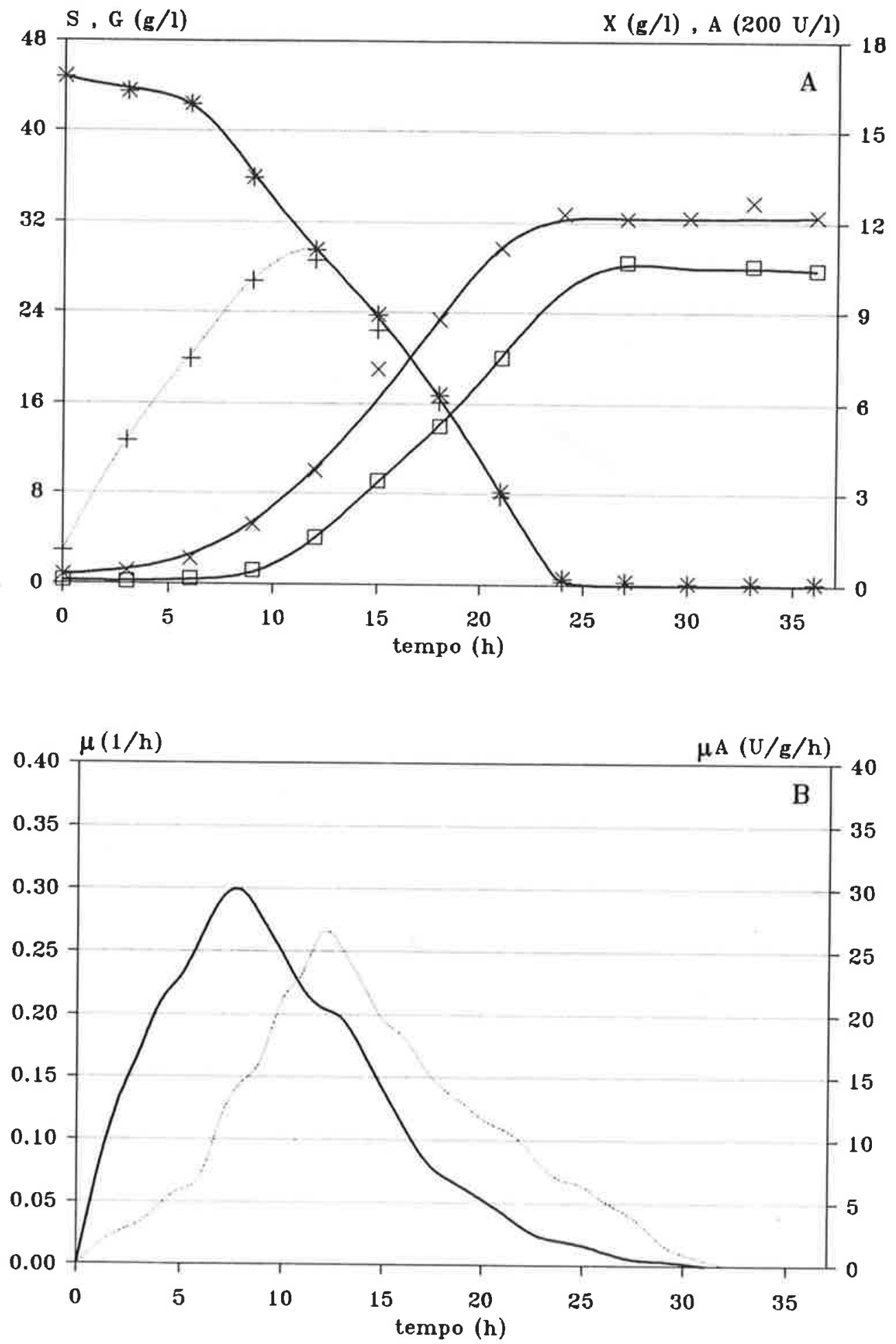

Figura 4.6 Resultados obtidos no ensaio B41 ( $1^{\circ}$ batch, $\left.40 \mathrm{~g} / 1\right)$.

A) Concentração de ART (S) $\left({ }^{*}\right)$, glicose $(\mathrm{G})(+)$, células $(\mathrm{X})(\mathrm{X})$ e atividade enzimática (A) (ㅁ)

B) Velocidades específicas de crescimento $(\mu)(-)$ e produção de enzima ( $\mu \mathrm{A})(-\cdot-)$ 

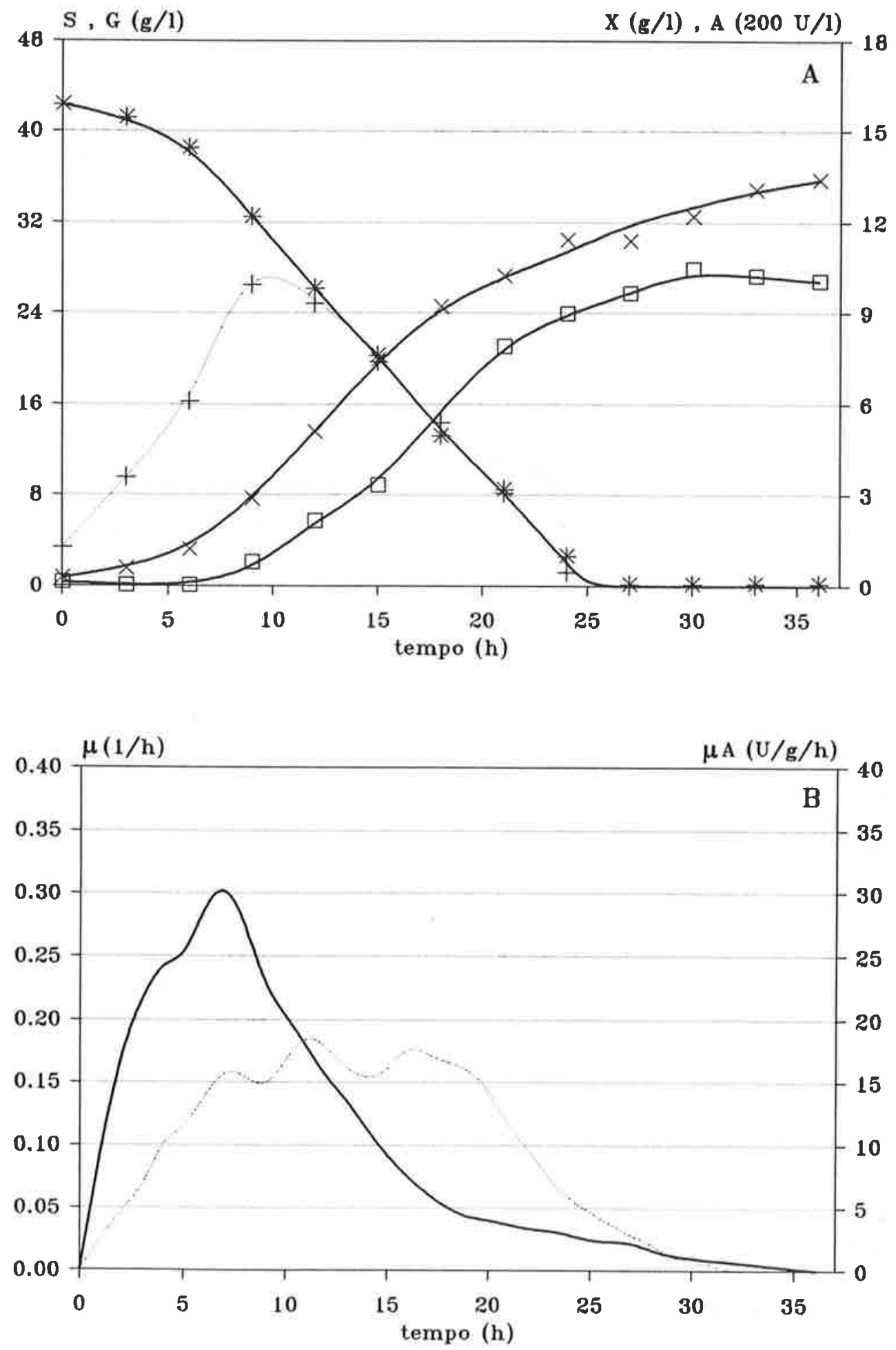

Figura 4.7 Resultados obtidos no ensaio B42 ( $2^{\circ}$ batch, $\left.40 \mathrm{~g} / \mathrm{l}\right)$.

A) Concentração de ART $(S)\left({ }^{*}\right)$, glicose $(G)(+)$, células $(X)(X)$ e atividade enzimática (A) ( $\square$ )

B) Velocidades específicas de crescimento $(\mu)(-)$ e produção de enzima ( $\mu \mathrm{A})(--\cdot)$ 


\subsubsection{Velocidades Específicas}

Com relação às velocidades específicas de crescimento $(\mu)$ e produção de glicoamilase ( $\mu \mathrm{A})$, também é importante uma pré-análise. 0 comportamento típico da curva de $\mu$ em função do tempo mostra altos valores até aproximadamente metade do cultivo, seguido de uma queda até zero com durações variadas, conforme apresentam as Figuras 4.2 a 4.7. As grandes diferenças que se observam entre as várias figuras, nas primeiras horas de cultivo, decorrem do fato de que é menor a precisão absoluta da medida de $X$ nesse periodo, por se tratar de valores menores. Na tentativa ainda de contornar este problema, foram traçadas curvas suavizadas de $\mathrm{X}$ em duas diferentes escalas, de modo a se poder ampliar os valores iniciais, pequenos em relação a todo o ensaio. Cuidado especial tomou-se ao traçar as curvas em torno dos instantes onde ocorre mudança de escala, para evitar descontinuidade em $\mu$.

Após essa fase inicial do crescimento, frequentemente $\mu$ se mantém em torno de $0,25 \mathrm{~h}^{-1}$ por algumas horas, até a concentração de substrato cair bastante, diminuindo em seguida até se anular quando a concentração celular atinge Xm. Segundo o Modelo de Monod (1942), desenvolvido para ensaios contínuos com diferentes concentrações de substrato, enquanto $S$ é elevado, $\mu$ se mantém próxima de $\mu_{\text {máx }}$ Com a diminuição de $S, \mu$ diminui até zero e se obtém Xm em torno de 8,5 g/l. Os ensaios com maior $S_{0}$ comportam-se semelhantemente, porém como se tem maior quantidade de substrato, $\mu$ permanece em valores baixos 
$\left(0,05 \mathrm{~h}^{-1}\right)$ por algumas horas a mais que a $20 \mathrm{~g} / \mathrm{l}$, resultando em concentrações celulares finais superiores a $12 \mathrm{~g} / \mathrm{l}$.

Há flutuações nos perfis de $\boldsymbol{\mu}$ entre os 4 ensaios descontínuos a mesma concentração inicial de ART. Algumas hipóteses serão abordadas no item 4.2.4. Na discussão final, item 4.5.1, a cinética de crescimento é apresentada de outra forma, enfocando o valor de velocidade específica máxima, acompanhada de algumas análises gerais do crescimento microbiano nos ensaios deste trabalho.

$O$ traçado da curva de $\mu$ A para os ensaios descontínuos a $S_{0}=20$ $\mathrm{g} / \mathrm{A}$ se assemelha à de $\mu$. Em dois ensaios (B21 e B22) $\mu \mathrm{A}$ atinge um alto valor máximo ( $\mu \mathrm{A}_{\text {máx }}$ ) em torno de $20 \mathrm{U} / \mathrm{h} / \mathrm{h}$ com cerca de 10 horas de cultivo, decaindo rapidamente, anulando-se entre 15 e 18 horas. Nos outros dois ensaios (B23 e B24), $\mu_{A}$ áx limita-se a $13 \mathrm{U} / \mathrm{h} / \mathrm{h}$, porém se estende até após 22 horas de cultivo, período com alta concentração celular, resultando em valores finais de atividade parecidos com os de B21 e B22.

Nos ensaios descontínuos com $S_{0}=40 \mathrm{~g} / \mathrm{l}$ (B41 e B42), observa-se claramente que $\mu \mathrm{A}$, ao atingir o máximo em torno de 12 horas de cultivo, apresenta valores superiores aos observados com $S_{0}=20 \mathrm{~g} /$, entre 20 e $25 \mathrm{U} / \mathrm{h} / \mathrm{h}$, e se mantém alto por mais tempo, o que aliado a maior concentração celular resulta em Am em torno de 2100 U/. 


\subsubsection{Reprodutibilidade dos Resultados: Aspectos Gerais}

Neste ponto torna-se relevante uma discussão a respeito da variabilidade de resultados. Todos os ensaios descontínuos a aproximadamente $20 \mathrm{~g} / \mathrm{l}(\mathrm{B} 2 \mathrm{n})$ foram realizados em igualdade de condições, com exceção das flutuações de $S_{0}$ em torno de $22 \mathrm{~g} / \mathrm{e}$, certamente, quanto à data de realização dos mesmos.

Apesar disto, os resultados obtidos apresentam diferenças não desprezíveis. Observando-se as Figuras 4.2 a 4.5 , vemos que as curvas de S, G, X e A não podem ser sobrepostas. Os ensaios B21 e B22, por exemplo, partem de $S_{0}$ muito semelhantes, 23,1 e $24,1 \mathrm{~g} / 1$ respectivamente, mas obtém-se atividades enzimáticas máximas no caldo (Am) diferentes, 653 e 512 U/1. Este fato, somado aos diferentes instantes em que se atinge Am (tA), levam a produtividade em enzima de B21 a ser 74\% superior a de B22, conforme Tabelas 4.2 e 4.3. O fator de conversão substrato a enzima de B21 é também maior que de B22 (30\%), a princípio sem motivos. Mesmo que considerássemos a atividade final do B22 como sendo em torno de $480 \mathrm{U} / \mathrm{em} 20 \mathrm{~h}$ de cultivo, isto resultaria em uma produtividade em enzima de $22 \mathrm{U} / \mathrm{h} / \mathrm{h}$, o que não altera substancialmente a discussão anterior.

Outro ponto a observar é a curva de $\mathrm{X}$ em função do tempo. Apesar das concentrações celulares finais $(\mathrm{Xm})$ serem próximas $(8,42 \mathrm{e}$ $8,01 \mathrm{~g} / 1$ ), a produtividade em células (PX) do ensaio B21 é 18\% superior a do ensaio B22. Além disso, temos em B21 após cerca de 18 horas de cultivo, uma perceptível lise celular, onde $X$ decai de 8,42 a 7,07 g/1. Tal 
fato não se observa em B22, pois X permanece em torno de 8,0 g/ $\mathrm{d}$ das 20 às 26 horas de cultivo.

Essas observações, somadas às que poderiam ser feitas numa comparação com os ensaios B23 e B24 (também a $S_{0}=20 \mathrm{~g} / 1$ ), ou entre B41 e B42 (a $\left.S_{0}=40 \mathrm{~g} / \mathrm{l}\right)$ levam-nos a seguinte constatação: a reprodutibilidade dos ensaios não é satisfatória, mesmo considerando o fato de serem processos fermentativos, nos quais não se espera a mesma reprodutibilidade de processos químicos não biológicos.

Conforme visto na Revisão Bibliográfica, o grupo de pesquisadores de Engenharia Bioquímica da Escola Politécnica da USP vem realizando há vários anos ensaios com este sistema substrato / microrganismo / produto, isto é, xarope de farinha de mandioca / Aspergillus awamori / glicoamilase. Ao longo deles, vários problemas foram enfrentados no que tange a reprodutibilidade.

Algumas causas podem ser apontadas, como as variações no preparo de xarope ou imprecisões das medidas, mas a principal refere-se a estabilidade do microrganismo como será visto em seguida. 


\subsubsection{Estabilidade da cepa produtora}

A estabilidade do microrganismo já foi estudada por Kilikian (1989) e Facciotti (1986) e constatou-se que a forma de preservação da cepa e o seu tempo de estocagem muito influenciam nos resultados dos ensaios ditos padrões: batch, $S_{0}=20 \mathrm{~g} /, \mathrm{pH}=4,0,35^{\circ} \mathrm{C}, 700 \mathrm{rpm}, 1 \mathrm{vwm}$. As observações feitas indicam que após algum tempo (cerca de 6 meses) de preservação em terra e areia (conforme descrito no item 3.1.2), obtém-se um microrganismo estável por vários anos, principalmente no que tange ao tempo de consumo da fonte de carbono e cinética de formação da enzima.

Isto pode ser visto pela Tabela 4.6 e Figura 4.8, onde são apresentados resultados de ensaios próprios deste trabalho juntamente com outros constantes do Relatório Técnico IPT/FINEP/PADCT (IPT, 1990) e da Tese de Doutoramento da Professora Beatriz Vahan Kilikian (Kilikian, 1989). 


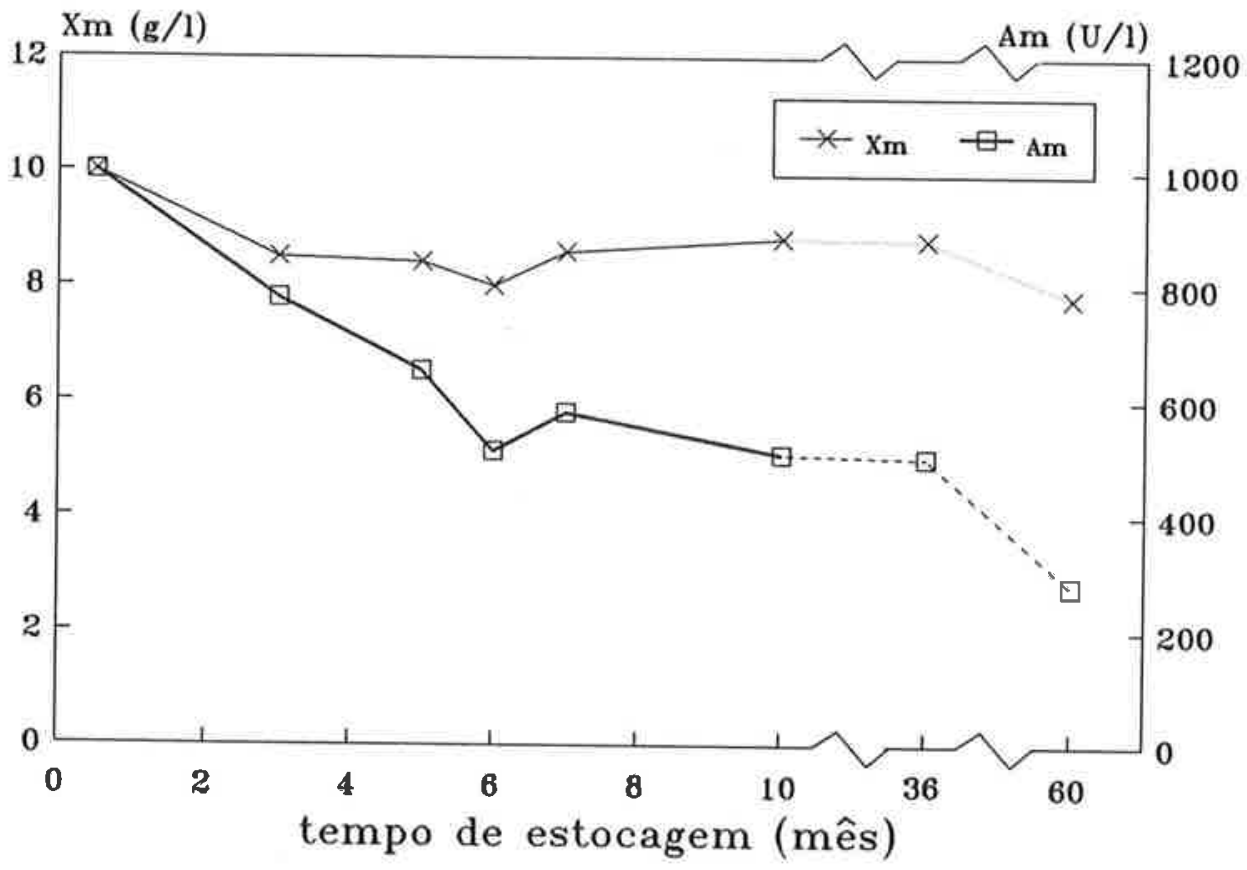

Figura 4.8 Comparacão de resultados entre ensaios anteriores e deste trabalho (batch, $S_{0}=20 \mathrm{~g} / \mathrm{l}$ ) 
Tabela 4.6 Comparação de resultados entre ensaios anteriores e deste trabalho (batch, $S_{0}=20 \mathrm{~g} / \mathrm{l}$ )

\begin{tabular}{|c|c|c|c|c|c|c|c|}
\hline Ident. & $\begin{array}{c}\text { t.e. } \\
\text { (mềs) }\end{array}$ & $\begin{array}{l}\mathrm{Xm} \\
(\mathrm{g} / \mathrm{I})\end{array}$ & $\begin{array}{l}\text { YX/S } \\
(\mathrm{g} / \mathrm{g})\end{array}$ & $\begin{array}{c}\mathrm{PX} \\
(\mathrm{g} / \mathrm{h} / \mathrm{h})\end{array}$ & $\begin{array}{c}\mathrm{Am} \\
(\mathrm{U} / \mathrm{A})\end{array}$ & $\begin{array}{l}\mathrm{YA} / \mathrm{S} \\
\text { (U/g) }\end{array}$ & $\begin{array}{c}\mathrm{PA} \\
(\mathrm{U} / \mathrm{h})\end{array}$ \\
\hline D-7 & 0.5 & 10.0 & 0.43 & 0.54 & 1000 & 43 & 51 \\
\hline D-8 & 3 & 8.5 & 0.34 & 0.45 & 780 & 31 & 31 \\
\hline B21 & 5 & 8.4 & 0.35 & 0.45 & 653 & 26 & 33 \\
\hline $\mathrm{B} 22$ & 6 & 8.0 & 0.32 & 0.38 & 512 & 19 & $\begin{array}{l}33 \\
19\end{array}$ \\
\hline B23 & 7 & 8.6 & 0.39 & 0.37 & 580 & 26 & 23 \\
\hline B24 & 10 & 8.8 & 0.40 & 0.39 & 507 & 22 & 22 \\
\hline DTA13 & 36 & 8.8 & 0.39 & 0.54 & 500 & 22 & 27 \\
\hline D-6 & 60 & 7.8 & 0.38 & 0.34 & 280 & 13 & 13 \\
\hline
\end{tabular}

Obs.: Ident.= identificaçâo do ensaio
t.e. = tempo de estocagem da linhagem ensaios D-6 e DTA13: linhagem anterior ensaios D-6, D-7 e D-8 (IPT, 1990) ensaio DTÁ13 (Kilikian, 1989)

Percebe-se claramente a existência de 3 fases durante a preservação da linhagem em terra e areia a partir da ampola contendo o liofilizado e que passa-se a descrever a seguir:

- Decaimento Inicial: Pouco após ser aberta a ampola, o microrganismo apresenta Xm, Am, YA/S e PA máximos. Com o passar dos primeiros 6 meses, esses valores diminuem, atingindo um patamar. Esse efeito não é tão claro em PX e YX/S, só se percebendo diferença entre o primeiro ponto com 15 dias de preservação, no qual se obteve $\mathrm{Xm}$ de $10,0 \mathrm{~g} / \mathrm{l}$ e consequentemente $\mathrm{YX} / \mathrm{S}$ e PX atípicos. Ao longo desta fase, observa-se a queda de Am de $1000 \mathrm{U} / 1$ para cerca de $500 \mathrm{U} / \mathrm{l}$.

- Fase Estacionária: Após 6 meses, as várias repetições dos ensaios padrão apresentam flutuações características de processos fermentativos, sem contudo indicar uma queda no crescimento ou produção de enzima. Durante esta fase obtém-se resultados que serão considerados típicos para $S_{0}=20 \mathrm{~g} / \mathrm{l}$ e são apresentados na Tabela 4.7. 
Tabela 4.7 Resultados típicos de ensaios a $\mathrm{S}_{\mathrm{o}}=20 \mathrm{~g} / \mathrm{l}$ na Fase Estacionária

\begin{tabular}{|cccccccc|}
\hline $\mathrm{Xm}$ & $\mathrm{Am}$ & $\mathrm{tX}$ & $\mathrm{tA}$ & $\mathrm{YX} / \mathrm{S}$ & $\mathrm{YA} / \mathrm{S}$ & $\mathrm{PX}$ & $\mathrm{PA}$ \\
$(\mathrm{g} / \mathrm{l})$ & $(\mathrm{U} / 1)$ & $(\mathrm{h})$ & $(\mathrm{h})$ & $(\mathrm{g} / \mathrm{g})$ & $(\mathrm{U} / \mathrm{l})$ & $(\mathrm{g} / \mathrm{h} / \mathrm{h})$ & $(\mathrm{U} / \mathrm{h} / \mathrm{h})$ \\
8,5 & $500 / 550$ & 22 & 22 & 0,35 & 22 & 0,38 & 22 \\
\hline
\end{tabular}

Cabe aqui ressaltar que com exceção dos ensaios realizados em 15/08/90 (B21, F22 e F23), todos os outros deste trabalho incluem-se nesta fase. A duração dela não foi precisamente determinada, porém se estende por alguns anos. Há ensaios apresentados por Kilikian (1989) após 3 anos de preservação, onde não se observa perda de capacidade produtiva, atingindo "ainda" atividade enzimática de $500 \mathrm{U} / 1$.

- Decaimento Final: Após cerca de 60 meses, há uma queda sensível na síntese de glicoamilase, que só chega a atingir $280 \mathrm{U} /$, ocasionando uma diminuição de YA/S e PA para 13 U/1 e $13 \mathrm{U} / \mathrm{g}$, respectivamente. No crescimento celular há também uma queda, porém não tão intensa.

Os resultados mencionados de ensaios com 3 e 5 anos de preservação referem-se a microrganismos obtidos de um outro lote, isto é, de culturas repicadas em terra e areia geradas a partir de outra ampola liofilizada. Apesar deste fato, o comportamento ao longo do tempo deste outro lote é muito semelhante ao ocorrido, em seu período inicial, ao lote utilizado no presente trabalho, e seus resultados podem ser com ele comparados.

Os ensaios descritos neste trabalho partiram de microrganismos com idade de estocagem entre 5 e 15 meses, o que a princípio nos leva a crer que a maior parte dos ensaios foi feita com microrganismos na 
mesma condição. Entretanto, a cepa nos primeiros ensaios (B21, F22 e F23), realizados na $1^{\text {a }}$ semana de ensaio $(15 / 08 / 90)$ ainda não estava completamente estabilizada.

Isso bem se observa nestas várias repetições das mesmas condições de ensaio. $O$ ensaio $B 21$ foi o primeiro descontínuo a $S_{0}=20$ g/1 realizado, após preservação por 5 meses em terra e areia, apresentando os melhores resultados, tanto em crescimento como síntese enzimática. Além de menor tempo para consumir a fonte de carbono (tX) - 18 em relação a 20 e 22 horas dos outros ensaios, atinge maior Am (650 U/1 versus cerca de 520) em menor tempo: $t A=18 \mathrm{~h}$, em comparação de 22 e 24 h. Os resultados de B22, B23 e B24, realizados com mais de 6 meses de estocagem e provavelmente já estabilizados, mostram-se mais semelhantes entre si.

\subsubsection{Preparo do Xarope de Farinha de Mandioca e do Meio de Cultura}

A concentração inicial do substrato $\left(S_{0}\right)$ é também uma possível geradora de flutuações, pois não se consegue repetir com precisão condições iniciais como se vê nos vários ensaios $\mathrm{B} 2 \mathrm{n}$. Isso se deve basicamente a flutuações provocadas pela evaporação durante a esterilização do meio de cultivo e pela imprecisão na formulação do meio a partir de xarope com concentração de cerca de 300 gART/1. Ocorre que, a variação observada nos resultados não é sempre na direção esperada. Facciotti (1986) mostrou que na faixa de $S_{0}$ entre 20 e $80 \mathrm{~g} / 1$, a curva da atividade enzimática máxima (Am) em função de $S_{0}$ é 
sempre crescente, isto é, um aumento de $S_{0}$ originaria um acréscimo na atividade enzimática máxima, o que não ocorre por exemplo, se compararmos Am e $S_{0}$ de B22 e B23. O ensaio B22 partiu de um $S_{0} 16 \%$ maior que B23, porém resultou em um Am 12\% menor.

Com relação ao xarope, outra observação deve ser feita. Recentemente tem-se constatado que pequenas diferenças no preparo do xarope de farinha de mandioca, até então consideradas insignificantes, podem ser responsáveis por diferenças na composição final deste xarope. Elas ocorrem principalmente na fase de dextrinização, através da ação da $\alpha$-amilase sobre o amido gelatinizado. $O$ instante em que a $\alpha$-amilase é misturada, a duração e a temperatura em que ocorre sua ação até a inativação parecem ser fundamentais na geração de maiores ou menores quantidades de açúcares intermediários (entre o amido e a glicose), em especial a maltose, considerada por vários autores (Barton et al., 1972, Ramachandran et al., 1979, Chiquetto, 1990) como o verdadeiro indutor da síntese da glicoamilase. Dessa forma, pode-se considerar que parte da variabilidade de resultados seja devida a variaçóes no preparo do xarope, a partir da farinha de mandioca, ocasionando diferentes quantidades iniciais de indutor no caldo de fermentação.

Em uma visão ampla, vê-se que nos processos fermentativos, e talvez neste sistema em particular, incluem-se vários geradores de variabilidade de parâmetros não totalmente conhecidos e controlados. Em outras áreas da Engenharia Química, como por exemplo, o estudo da mecânica dos fluidos, conseguem-se reprodutibilidade e precisão mais satisfatórias, de modo a facilitar a análise de resultados e 
conclusões. Foi justamente o conhecimento destes fatos, que norteou a decisão de simultaneamente a cada ensaio descontínuo alimentado, conduzir-se um ensaio descontínuo padrão, como pode ser visto na Tabela 3.2.

Quanto aos ensaios descontínuo a $S_{0}=40 \mathrm{~g} /$, observa-se que B41 apresenta um comportamento mais típico, enquanto que a curva de crescimento celular de B42 mostra-se sem um patamar definido (fase estacionária) ou uma queda (fase de lise celular) no final do cultivo. Este fato volta a justificar uma certa cautela na análise dos dados. No caso, pela experiência anterior, os resultados do ensaio B41 tornam-se mais confiáveis que de B42. 


\subsection{Ensaios Descontínuos Alimentados a $S_{0}=20 \mathrm{~g} / 1$}

Os ensaios descontínuos alimentados apresentam relevantes diferenças quanto ao perfil de $S$ e $\mathrm{G}$ em função do tempo, fruto do fato do substrato ser apresentado ao microrganismo parceladamente. Adiante será feita uma análise de cada conjunto de ensaios descontínuos alimentados, porém cabe aqui já salientar que as principais diferenças a serem observadas são as curvas de $S$ e $G(t)$ e os valores finais mais elevados da atividade enzimática, enquanto que o crescimento microbiano quase não se altera.

\subsubsection{Ensaios F21, F22, F23 e F24}

Como descrito no item 3.3, os ensaios F21, F22, F23 e F24 mantém em comum uma série de características: foram realizados com $\mathrm{St}=20$ g/1, alimentados a partir de 4 horas de cultivo e com xarope não hidrolisado. Entre eles, a única diferença é o tempo de alimentação do xarope $(\Delta \theta)$ e consequentemente a vazão mássica de alimentação (fs).

Assim serão comparados entre si e com os ensaios descontínuos B2n em busca da influência da vazão de alimentação sobre a síntese de glicoamilase. Seus resultados estão apresentados nas Figuras 4.9, 4.10, 4.11 e 4.12 . 

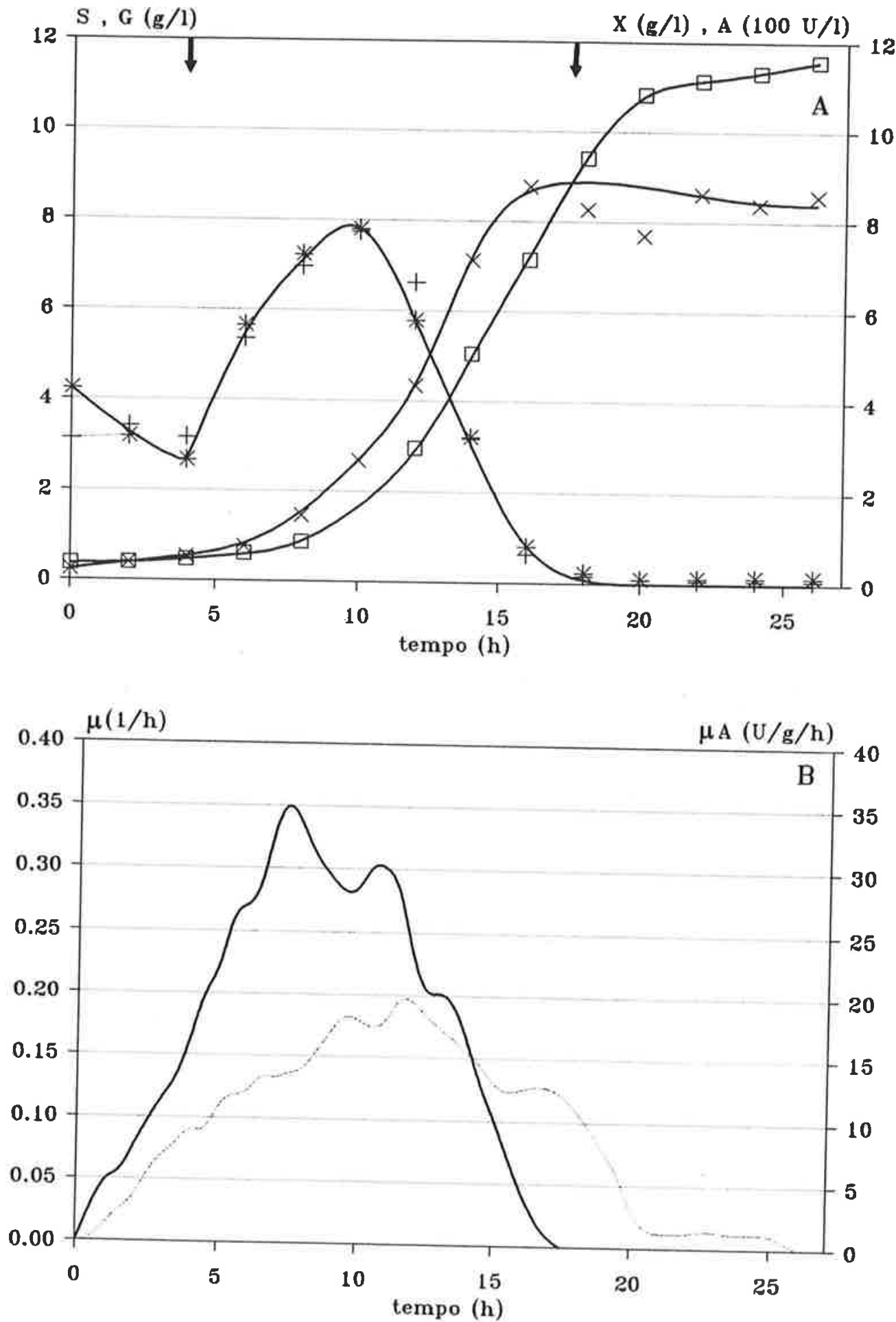

Figura 4.9 Resultados obtidos no ensaio F21 (fed-batch, $20 \mathrm{~g} / \mathrm{l}$,
fs=13,3 gART/h). A) Concentração de ART $(S)\left({ }^{*}\right)$, glicose $(G)(+)$, células $(X)(X)$ e atividade enzimática (A) (a) (as setas indicam o início e o final da alimentação)

B) Velocidades específicas de crescimento $(\mu)(-)$ e produção de enzima ( $\mu \mathrm{A})(-$ - -) 

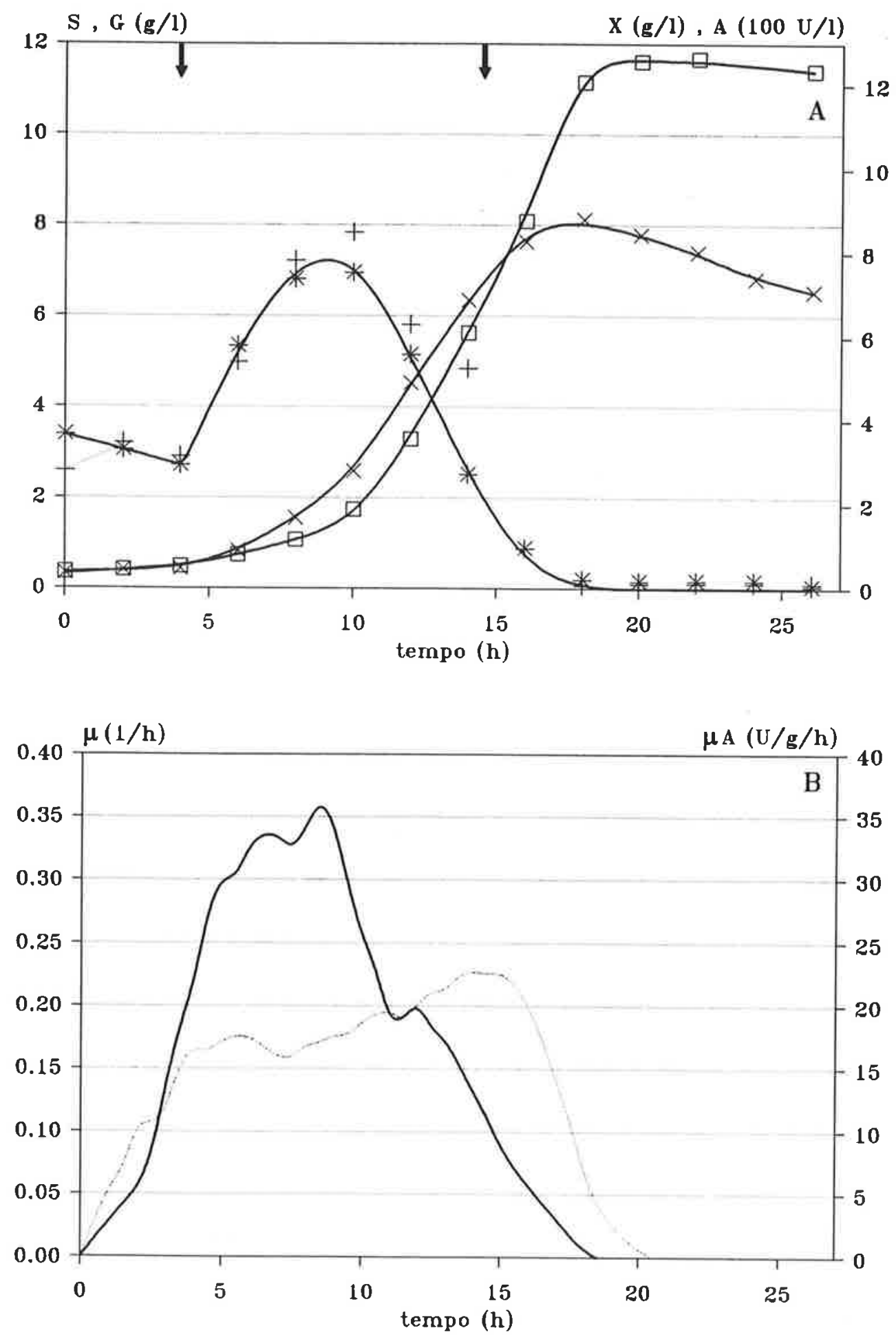

Figura 4.10 Resultados obtidos no ensaio F22 (fed-batch, $20 \mathrm{~g} /$, fs $=17,1 \mathrm{gART} / \mathrm{h}$ ).

A) Concentração de ART $(S)\left({ }^{*}\right)$, glicose $(G)(+)$, células $(X)(X)$ e atividade enzimática (A) (a) (as setas indicam $o$ início e o final da alimentação)

B) Velocidades específicas de crescimento $(\mu)(-)$ e produção de enzima $(\mu \mathrm{A})(-$ - -) 

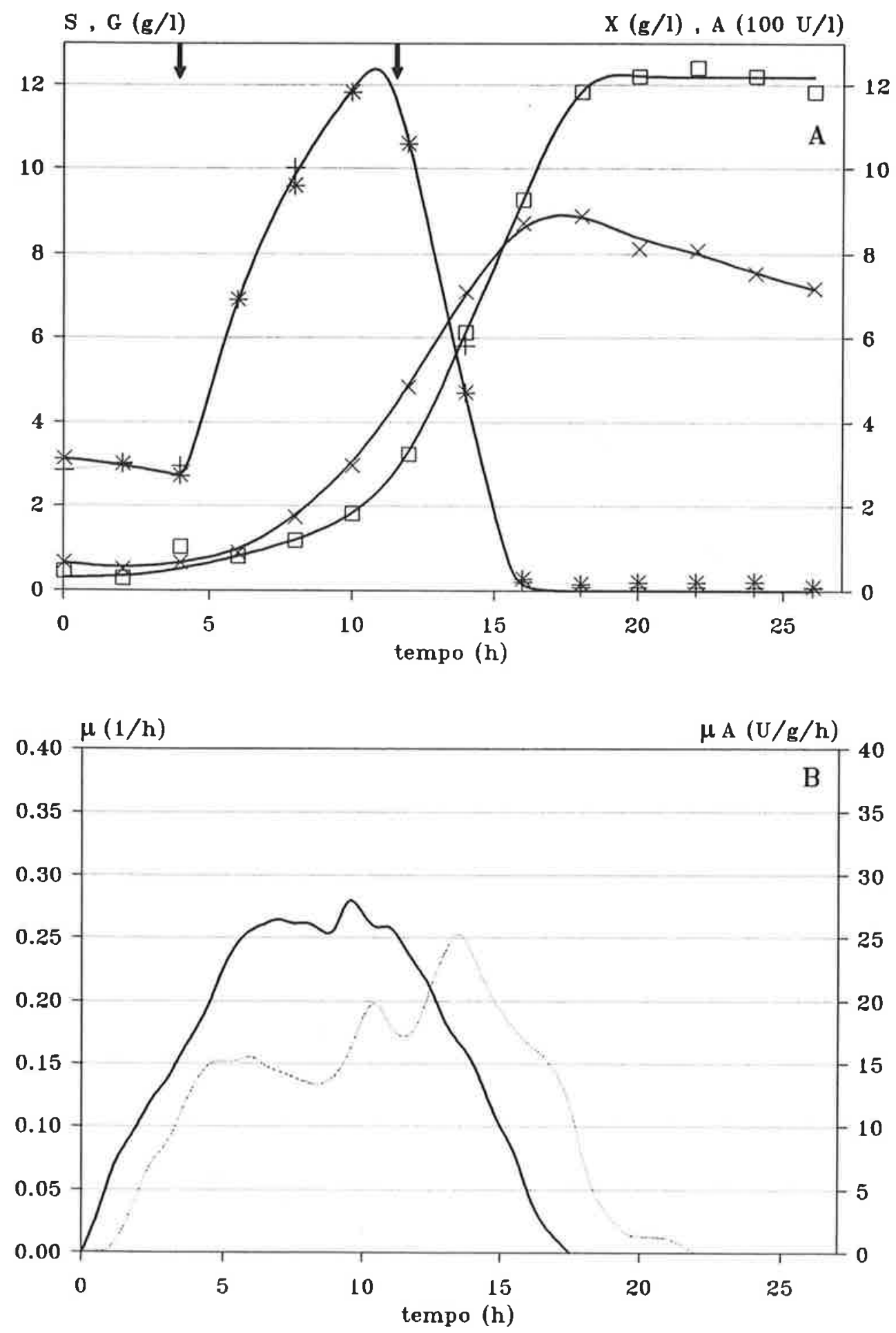

Figura 4.11 Resultados obtidos no ensaio F23 (fed-batch, $20 \mathrm{~g} /$, fs=23,7 $\mathrm{gART} / \mathrm{h}$ ).

A) Concentração de ART $(S)\left({ }^{*}\right)$, glicose $(G)(+)$, células $(X)(X)$ e atividade enzimática (A) (a) (as setas indicam o início e o final da alimentação)

B) Velocidades específicas de crescimento $(\mu)(-)$ e produção de enzima ( $u$ A) (- - -) 

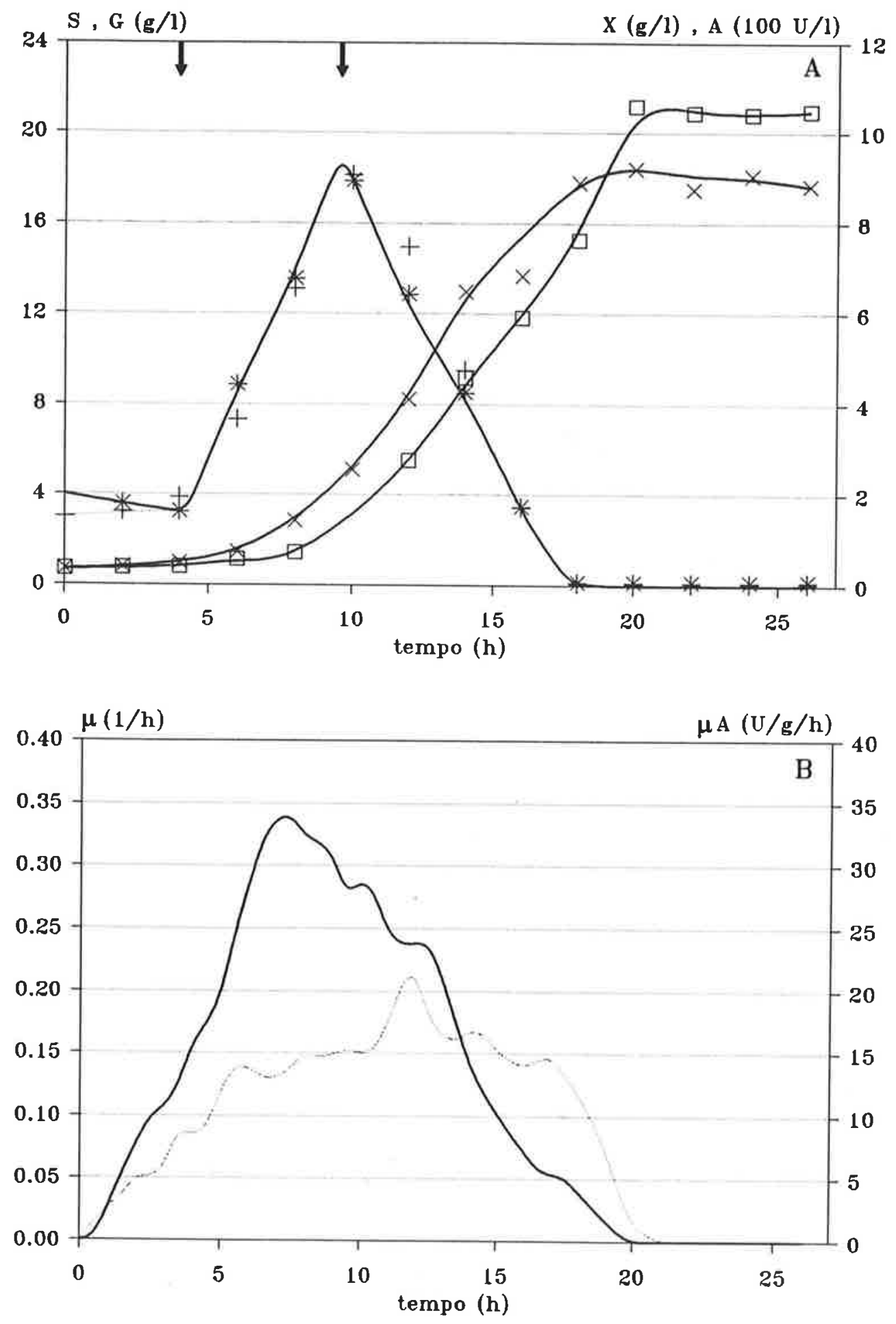

Figura 4.12 Resultados obtidos no ensaio F24 (fed-batch, $20 \mathrm{~g} / \mathrm{l}$, fs $=32,1$ gART/h).

A) Concentração de ART $(S)\left({ }^{\star}\right)$, glicose $(G)(+)$, células $(X)(X)$ e atividade enzimática (A) (a) (as setas indicam o início e o final da alimentação)

B) Velocidades específicas de crescimento $(\mu)(-)$ e produção de enzima $(\mu \mathrm{A})(---)$ 
E conhecido (item 2.2) que na sintese de enzimas, e em especial da glicoamilase, frequentemente atuam mecanismos de repressão e indução. 0 processo descontínuo alimentado, por oferecer o substrato parceladamente, permite alterações nos perfis típicos da fonte de carbono, influenciando na indução e repressão.

Assim, observa-se nestes 4 ensaios (F21 a F24), que as curvas de $S(t)$ e $G(t)$ apresentam formas completamente diferentes das dos ensaios B2n.

A concentração inicial de ART $\left(S_{0}\right)$ é pequena, da ordem de 3,5 $\mathrm{g} / \mathrm{l}$, e nas primeiras horas ainda diminui, visto que a alimentação só é iniciada no instante $4 \mathrm{~h}$, período de tempo que inclui a fase lag, durante a qual o microrganismo praticamente não consome substrato.

A partir de 4 horas de cultivo e devido à alimentação, a concentração de substrato cresce quase que linearmente até atingir um máximo, após o qual assemelha-se a um processo descontínuo, diminuindo até se anular.

Para a análise das curvas $S(t)$ e $G(t)$ destes 4 ensaios descontínuos alimentados, eles serão agrupados 2 a 2 em função das vazões de alimentação (fs) crescentes. F21 e F22 foram alimentados mais lentamente ( $\mathrm{fs}=13,3$ e $17,1 \mathrm{gART} / \mathrm{h}$, respectivamente), enquanto que as vazões de alimentação de F23 e F24 foram superiores $(23,7$ e 32,1 $\mathrm{gART} / \mathrm{h}$ ).

De modo geral, de F21 a F24 tem-se vazões de alimentação crescentes. Dessa forma, dS/dt após o início da alimentação é maior em F24 e menor em F21 e da mesma forma, o substrato atinge um maior valor em menos tempo em F24 em relação aos demais. 
Nos ensaios F23 e F24, como as vazões de alimentação foram relativamente altas, o máximo atingido coincide com o final da alimentação, pois ainda o consumo de substrato pelo total de células (dS/dt de consumo) pode ser suprido pela alimentação. Assim atingido esse máximo, a curva $S(t)$ comporta-se como em um ensaio descontínuo.

Já nos ensaios F21 e F22, o substrato alimentado a partir de cerca de 10 horas de cultivo não basta para repor aquele consumido pelos microrganismos, e $S(t)$ começa a diminuir antes do final da alimentação. Por outro lado, sendo menor fs, o valor máximo de $S$ não ultrapassa 8 $\mathrm{g} / \mathrm{l}$, enquanto que nos outros 2 ensaios chega a 12 e $18 \mathrm{~g} / \mathrm{l}$. Observa-se também que as curvas $S(t)$ destes 2 ensaios são muito próximas. Nos 4 ensaios a concentração de substrato anula-se em torno de 16 a 18 horas de cultivo, porém deve-se lembrar que no ensaio F21 houve alimentação até 17,5 horas, de modo que nos últimos instantes de alimentação o xarope repunha o substrato consumido mantendo S e G muito próximos a $0 \mathrm{~g} / \mathrm{l}$.

As curvas de glicose em função do tempo apresentam-se também bem diferentes dos ensaios descontínuos. Na realidade, só se observa $\mathrm{G}(\mathrm{t})$ diferente de $\mathrm{S}(\mathrm{t})$ nas primeiras 2 horas de cultivo. Todas as outras determinações, com exceção de pequenas diferenças devido a erros experimentais, não indicam a presença de polissacarídeos ou quaisquer açúcares diferentes de glicose. Isso se deve ao fato de se estar lentamente oferecendo polissacarídeo ao meio de reação, de modo que a glicoamilase presente no caldo de fermentação (mesmo não estando nas melhores condições cinéticas de ação) é capaz de hidrolisá-lo rapidamente. Convém lembrar que apesar de não se conseguir dosar, 
uma pequena concentração de polissacarídeo deve estar presente no meio durante toda a alimentação, talvez em quantidade suficiente para que ocorra indução à síntese da enzima.

Assim, tanto quanto a quantidade de polissacarídeo oferecido ao microrganismo é menor nas primeiras horas de cultivo do que em ensaio descontínuos, também o é a quantidade de glicose, responsável pela repressão catabólica. Diferentemente dos ensaios descontínuos, a glicose mantém-se em concentrações bem pequenas até 6 ou 8 horas de cultivo. Mais para frente, isto se mostrará muito importante.

As curvas de concentração celular nestes ensaios descontínuos alimentados se assemelham muito às dos seus análogos descontínuos (B2n), em especial ao ensaio B21 que, como já visto, destaca-se um pouco dos demais em termos de tempo de estocagem da linhagem (item 4.2.5), por situar-se entre o decaimento inicial e a fase estacionária. Não se percebe nenhuma diferença entre os vários ensaios com diferentes fs. Ainda observando-se os gráficos de $\mu(t)$, percebe-se que, tendo em vista a variabilidade de resultados dos ensaios $B 2 n$, pouco se pode afirmar com relação a influência do processo no crescimento celular. Na discussão final (item 4.5.1), analisa-se a cinética de crescimento através do $\mu_{\text {máx }}$ e algumas hipóteses são levantadas. 
Tabela 4.8 Grandezas usadas no cálculo de fatores de conversão e produtividades para os ensaios F21, F22, F23 e F24.

\begin{tabular}{|cccccccc|}
\hline Ensaio & $\begin{array}{c}\mathrm{S}_{\mathrm{O}} / \mathrm{St} \\
(\mathrm{g} / \mathrm{l})\end{array}$ & $\begin{array}{c}\mathrm{tX} \\
(\mathrm{h})\end{array}$ & $\begin{array}{c}\mathrm{Xo} \\
(\mathrm{g} / \mathrm{l})\end{array}$ & $\begin{array}{c}\mathrm{Xm} \\
(\mathrm{g} / \mathrm{l})\end{array}$ & $\begin{array}{c}\mathrm{tA} \\
(\mathrm{h})\end{array}$ & $\begin{array}{c}\text { Ao } \\
(\mathrm{U} / 1)\end{array}$ & $\begin{array}{r}\text { Am } \\
(\mathrm{U} / \mathrm{l})\end{array}$ \\
F21 & 24,1 & 16 & 0,23 & 8,76 & 22 & 36 & 1112 \\
F22 & 23,1 & 18 & 0,34 & 8,79 & 20 & 38 & 1255 \\
F23 & 23,1 & 16 & 0,31 & 8,70 & 20 & 44 & 1219 \\
F24 & 24,1 & 18 & 0,34 & 8,89 & 20 & 34 & 1057 \\
\hline
\end{tabular}

Tabela 4.9 Grandezas calculadas: fatores de conversão e produtividades para os ensaios F21, F22, F23 e F24.

\begin{tabular}{|rcccc|}
\hline Ensaio & $\begin{array}{c}\text { YX/S } \\
(\mathrm{g} / \mathrm{g})\end{array}$ & $\begin{array}{c}\mathrm{PX} \\
(\mathrm{g} / \mathrm{h} / \mathrm{h})\end{array}$ & $\begin{array}{c}\mathrm{YA} / \mathrm{S} \\
(\mathrm{U} / \mathrm{g})\end{array}$ & $\begin{array}{c}\mathrm{PA} \\
(\mathrm{U} / \mathrm{h} / \mathrm{h})\end{array}$ \\
$\mathrm{F} 21$ & 0,35 & 0,53 & 44 & 48 \\
$\mathrm{~F} 22$ & 0,37 & 0,47 & 52 & 60 \\
F23 & 0,36 & 0,52 & 50 & 58 \\
F24 & 0,35 & 0,48 & 42 & 51 \\
\hline
\end{tabular}

Por outro lado, a síntese de glicoamilase nos ensaios descontínuos alimentados é fortemente estimulada e se obtém Am $100 \%$ superiores aos ensaios descontínuos, conforme se observa nas Tabelas 4.8 e 4.9. Nos ensaios F22 e F23, chega-se a cerca de 1240 U/, que como já foi visto, deve ser comparado com as 653 U/1 do ensaio B21, contemporâneo a esses. Da mesma forma, Am dos ensaios F21 e F24 situou-se em torno de $1080 \mathrm{U} / 1$, o que também representa o dobro do resultado em atividade enzimática de seu contemporâneo B22 (512 U/1). 
Uma análise das curvas de $\mu \mathrm{A}$ mostra que, apesar de atingir também máximos em torno de $20 \mathrm{U} / \mathrm{g} / \mathrm{h}$, nos ensaios descontínuos alimentados o período de alto $\mu \mathrm{A}$, digamos acima de $15 \mathrm{U} / \mathrm{g} / \mathrm{h}$, mantém-se por mais tempo (até cerca de 17 horas de cultivo) do que nos descontínuos (em torno de $13 \mathrm{~h}$ ). Isto, somado ao maior número de células neste período, conduz às maiores $\mathrm{Am}$, bem como produtividade em enzima em média de $55 \mathrm{U} / \mathrm{h} / \mathrm{h}$ (104\% superior aos descontínuos) e fator de conversão substrato a enzima $48 \mathrm{U} / \mathrm{g}$ (108\% superior aos descontínuos).

Assim, diferentemente da análise de $\mathrm{X}$, para estas condições de ensaio, o processo descontínuo alimentado tem influência relevante na síntese de glicoamilase. Isto pode ser explicado pela atuação positiva de dois fatores: indução e repressão.

Nos ensaios descontinuos alimentados, tem-se durante longos períodos a adição de polissacarídeos. Dessa forma, pode-se supor a existência de alguma concentração de polissacarídeos, mesmo que não mensurável. Em relação aos ensaios descontínuos, a indução certamente não pôde ser tão intensa, pela inexistência de grandes quantidades de polissacarídeo no início do cultivo, porém talvez tenha ocorrido durante toda fase exponencial de crescimento. Em relação aos ensaios batch, isso pode ser relevante, visto que nestes todo polissacarídeo já se encontrava hidrolisado a partir de cerca de 8 horas de cultivo.

Com relação à quantidade de glicose, claramente tem-se nos ensaios descontínuos alimentados uma diminuição da repressão catabólica, pois a célula não percebe concentrações de glicose altas no início do cultivo, como acontece nos ensaios descontínuos, após a 
enzima ter hidrolisado o polissacarídeo presente - já a partir de 4 horas de cultivo. A presença de altas concentrações de glicose após 8 ou $10 \mathrm{~h}$, como observado nos ensaios F23 e F24, não parece interferir negativamente na síntese de glicoamilase, pois nestes ensaios obtém-se igualmente boas produções de enzima, como em F21 e F22.

Na busca de uma melhor definição da influência de cada um dos fatores citados (indução e repressão), ainda a $S_{0}=20 \mathrm{~g} / \mathrm{l}$, tem-se como objetivo escolher um ensaio a partir do qual sejam feitas alterações de processo. A princípio, qualquer um dos 4 ensaios F2n seriam válidos, por apresentarem resultados semelhantes quanto à síntese de glicoamilase. A vazão mássica de F21 (13,3 gART/h) mostrou ser muito baixa, acarretando uma possivel falta de substrato no final da alimentação, quando o microrganismo já consumiu o que havia sido acumulado e praticamente fica na dependência do que é adicionado a cada instante. Por outro lado, os ensaios F22 e F23 apresentaram Am ligeiramente superior ao de F21 e F24, possivelmente por terem sido realizados com o microrganismo ainda não totalmente estável (item 4.2.5). O uso de um destes ensaios como base de comparação dificultaria a análise dos resultados seguintes. Por exclusão, não apresentando nenhum inconveniente, optou-se por F24, isto é, manter-se fs em torno de $32 \mathrm{gART} / \mathrm{h}$.

A seguir serão apresentados ensaios variantes a partir deste escolhido F24. 


\subsubsection{Ensaios F2H e F2I}

No intuito de se estudar o efeito de indução, foi preparado o ensaio F2H, conforme descrito no item 3.3.2. O meio de alimentação foi previamente hidrolisado com glicoamilase comercial em excesso, de modo a apresentar concentração de polissacarídeos nula. Assim, poder-se-ia observar as diferenças com o ensaio F24, onde possivelmente tem-se durante toda a alimentação alguma quantidade de polissacarídeo. Os resultados estão apresentados na Figura 4.13.

Não foi dosada a concentração de ART, pois se supõem que seja igual a de glicose. Esta apresenta-se muito semelhante à de F24, indicando a princípio que a vazão de alimentação desejada foi atingida e que a velocidade com a qual o microrganismo consumiu substrato, agora exclusivamente glicose, não se alterou.

No entanto, o crescimento celular foi mais rápido que o de F24, talvez indicando maior facilidade de assimilação do substrato, já na forma de glicose. Os valores finais de $\mathrm{X}(\mathrm{t})$ também são superiores, resultando nos maiores valores (entre todos os ensaios deste trabalho) de YX/S e PX $(0,47 \mathrm{~g} / \mathrm{g}$ e $0,54 \mathrm{~g} / \mathrm{h} / \mathrm{h}$, respectivamente), conforme se constata nas Tabelas 4.10 e 4.11. Essa análise leva a crer na possibilidade de ter havido alguma imprecisão na elaboração do xarope hidrolisado, diferente dos demais, ocasionado talvez concentrações de ART reais maiores que se supõe pelas medidas realizadas. 

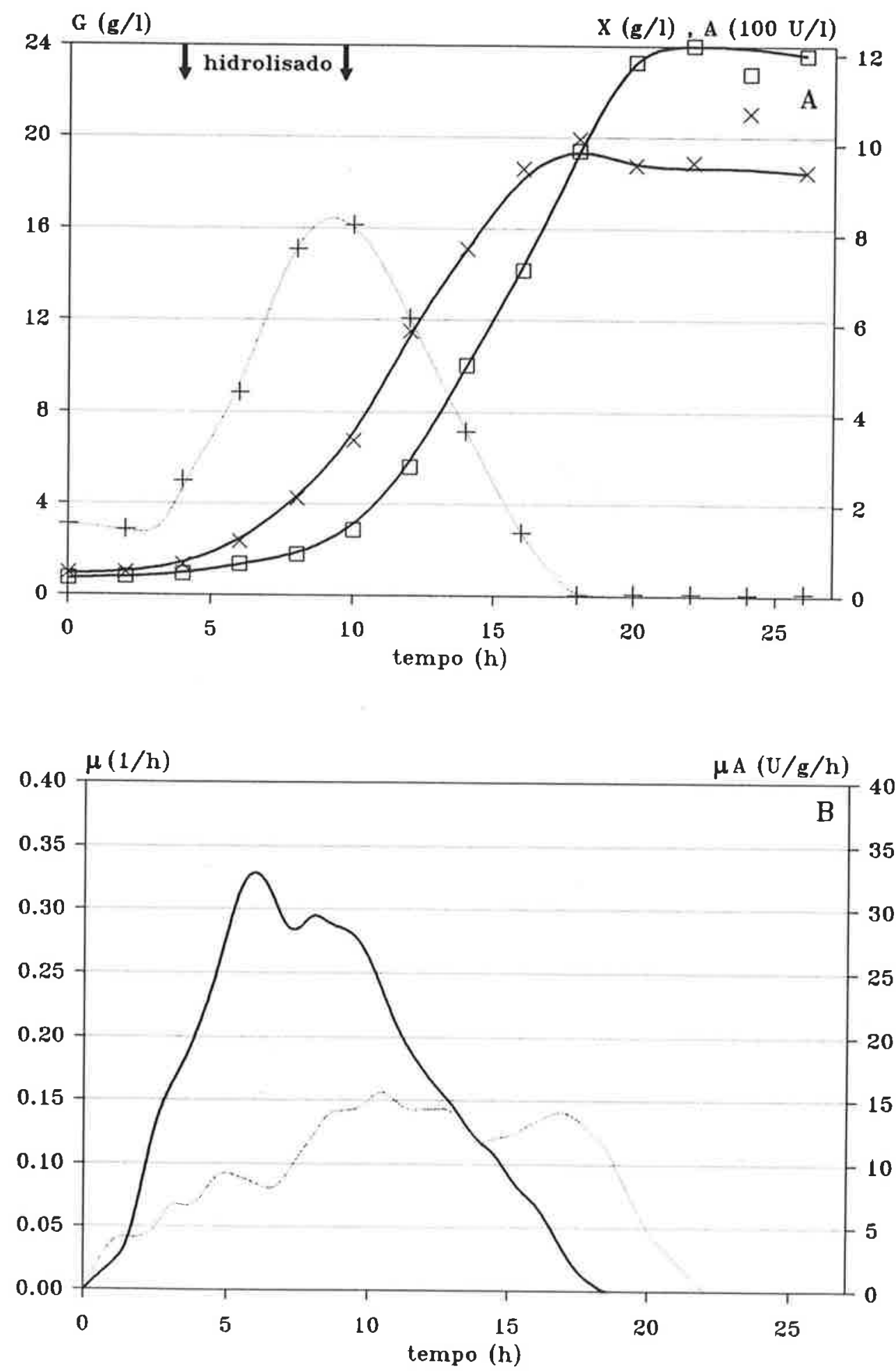

Figura 4.13 Resultados obtidos no ensaio F2H (fed-batch, $20 \mathrm{~g} /$, $\mathrm{fs}=31,6 \mathrm{gART} / \mathrm{h}$, xarope hidrolisado).

A) Concentração de glicose $(G)(t)$, células $(X)(X)$ e atividade enzimática (A) () (as setas indicam o início e o final da alimentação)

B) Velocidades específicas de crescimento $(\mu)(-)$ e produção de enzima $(\mu \mathrm{A})(--$-) 
Tabela 4.10 Grandezas usadas no cálculo de fatores de conversão e produtividades para os ensaios F2H e F2I.

\begin{tabular}{|rccccccc|}
\hline Ensaio & $\begin{array}{c}\mathrm{S}_{\mathrm{o}} / \mathrm{St} \\
(\mathrm{g} / \mathrm{l})\end{array}$ & $\begin{array}{c}\mathrm{tX} \\
(\mathrm{h})\end{array}$ & $\begin{array}{c}\mathrm{Xo} \\
(\mathrm{g} / \mathrm{l})\end{array}$ & $\begin{array}{c}\mathrm{Xm} \\
(\mathrm{g} / \mathrm{l})\end{array}$ & $\begin{array}{c}\mathrm{tA} \\
(\mathrm{h})\end{array}$ & $\begin{array}{c}\text { Ao } \\
(\mathrm{U} / \mathrm{l})\end{array}$ & $\begin{array}{c}\mathrm{Am} \\
(\mathrm{U} / \mathrm{l})\end{array}$ \\
F2H & 20,7 & 18 & 0,47 & 10,11 & 22 & 37 & 1220 \\
F2I & 20,7 & 18 & 0,52 & 9,00 & 20 & 38 & 752 \\
\hline
\end{tabular}

Tabela 4.11 Grandezas calculadas: fatores de conversão e produtividades para os ensaios F2H e F2I.

\begin{tabular}{|ccccc|}
\hline Ensaio & $\begin{array}{c}\text { YX/S } \\
(\mathrm{g} / \mathrm{g})\end{array}$ & $\begin{array}{c}\mathrm{PX} \\
(\mathrm{g} / \mathrm{h} / \mathrm{h})\end{array}$ & $\begin{array}{c}\mathrm{YA} / \mathrm{S} \\
(\mathrm{U} / \mathrm{g})\end{array}$ & $\begin{array}{c}\mathrm{PA} \\
(\mathrm{U} / \mathrm{l} / \mathrm{h})\end{array}$ \\
F2H & 0,47 & 0,54 & 57 & 53 \\
F2I & 0,41 & 0,47 & 34 & 35 \\
\hline
\end{tabular}

Quanto à síntese de glicoamilase, este ensaio nada deve ao seu análogo não hidrolisado $\mathrm{F} 24$, pois aqui se atinge $1200 \mathrm{U} / \mathrm{A}$ como nos melhores ensaios fed-batch a $S_{0}=20 \mathrm{~g} / 1$ deste trabalho (F22 e F23). Essas flutuações em torno de 1100 U/ não chegam a ser muito significativas, e são coerentes com a hipótese de a concentração total ser superior a calculada $(20,7 \mathrm{~g} / \mathrm{l})$, resultando em maior concentração celular e atividade enzimática. Pela análise de $\mu(\mathrm{t})$ e $\mu \mathrm{A}(\mathrm{t}$ ) (Figura 4.13), pelo fato de serem muito semelhantes a de F24, apenas se poderia confirmar a discussão anterior.

Os resultados obtidos com o ensaio $\mathrm{F} 2 \mathrm{H}$ indicam fortemente que as vantagens até aqui apresentadas dos ensaios descontínuos alimentados, quanto à síntese de glicoamilase, não se devem ao fato de 
se propor continuadamente polissacarídeo ao microrganismo, pois neste ensaio com xarope hidrolisado obteve-se resultados semelhantes aos com xarope não hidrolisado. Esta afirmação perde validade caso o fenômeno de indução possa se manifestar mesmo com quantidades mínimas de algum polissacarídeo, não detectáveis através das metodologias empregadas neste trabalho e presentes no xarope submetido a hidrólise prévia com glicoamilase. Dentro desta hipótese, fica difícil imaginar até, que em ensaios descontínuos, após o encontro das curvas de ART e glicose, não se teria mais polissacarídeo presente e portanto, não haveria nenhuma contribuição do efeito indutivo. Claro está que discussão como essa apenas poderia ser abordada, caso se pudesse dispor de metodologia analítica mais sofisticada, como a indicada por Mandels et al. (1962), para o estudo da síntese de celulase.

Para se obter mais informações a respeito da influência da repressão catabólica na síntese da enzima, executou-se o ensaio F2I, o qual difere de F24 simplesmente pelo fato da alimentação iniciar-se no instante zero, enquanto que em todos os outros ensaios iniciou-se com 4 horas de cultivo. Aqui o objetivo foi permitir maior acúmulo de glicose no início do cultivo, alterando-se os perfis de $S(t)$ e $G(t)$. Os resultados obtidos são apresentados na Figura 4.14. 

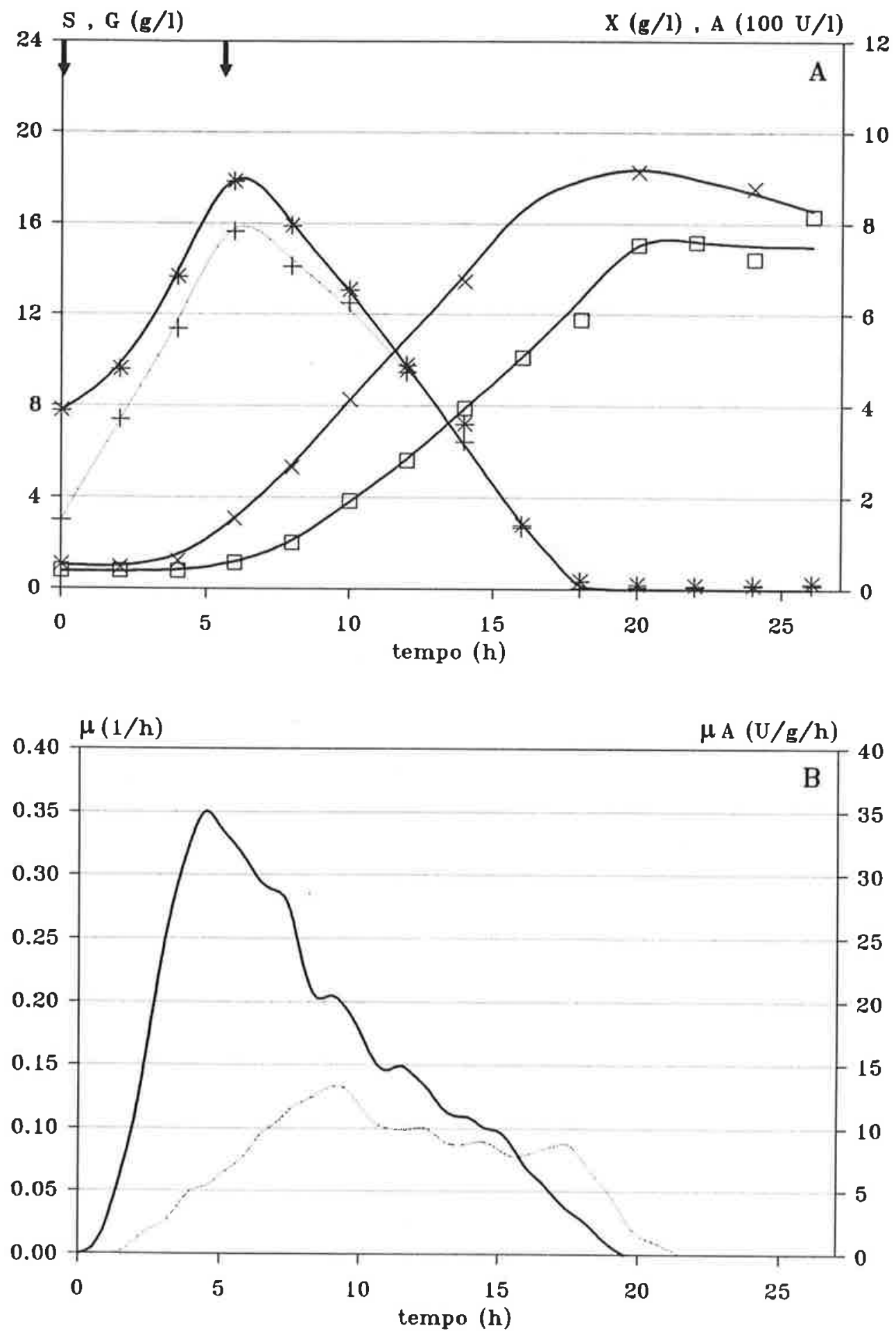

Figura 4.14 Resultados obtidos no ensaio F2I (fed-batch, $20 \mathrm{~g} /$, $\mathrm{fs}=31,6 \mathrm{gART} / \mathrm{h}$, alimentado desde início).

A) Concentração de ART $(S)\left({ }^{*}\right)$, glicose $(G)(+)$, células $(X)(X)$ e atividade enzimática (A) (ㅁ) (as setas indicam o início e o final da alimentação)

B) Velocidades específicas de crescimento $(\mu)(-)$ e produção de enzima ( $\mu \mathrm{A})(-$ - -) 
Claramente observa-se alterações nas curvas de substrato e glicose em função do tempo. A alimentação desde $t=0 \mathrm{~h}$ produz um acúmulo de substrato nas primeiras horas de cultivo, visto que o microrganismo ainda está em fase de adaptação e consome pouco substrato. Com 6 horas de cultivo, $S$ atinge cerca de $18 \mathrm{~g} / \mathrm{l}$ e $\mathrm{G} 16 \mathrm{~g} / \mathrm{l}$. Diferentemente dos outros ensaios até aqui vistos, neste as curvas de $S(t)$ e $G(t)$ nitidamente mantém-se afastadas por várias horas, encontrando-se após cerca de 12 horas de cultivo. A concentração máxima e mesmo a forma da curva de glicose muito se assemelha a de F24. Assim observa-se a presença de indutor durante 12 horas, enquanto que o repressor existe em níveis semelhantes a F24, porém adiantado em relação ao tempo de cultivo de cerca de 4 horas.

A curva de concentração celular novamente não apresenta diferenças significativas com relação à F24 ou às demais. Como muitos pontos experimentais foram perdidos, seu traçado proposto pode ser alterado, porém os pontos considerados coincidem com outros ensaios. As Tabelas 4.10 e 4.11, já citadas, apresentam os fatores de conversão e produtividades deste e do ensaio anterior.

O resultado surpreendente deste ensaio é sem dúvida a curva de atividade enzimática. Ao invés de atingir Am da ordem de 1000 ou 1200 U/A como seus análogos, ou ainda valores superiores por se observar claramente a presença de indutor, o máximo valor de atividade foi de $750 \mathrm{U} /$. $O$ perfil todo é inferior e a curva de $\mu \mathrm{A}$ demonstra que a sintese esteve prejudicada desde o início, atingindo um máximo de apenas $13 \mathrm{U} / \mathrm{h} / \mathrm{h}$ com 13 horas de cultivo. 
Em relação a um ensaio batch, este apresenta como única diferença a concentração de glicose (e de ART) um pouco mais baixa nas primeiras horas de cultivo. Sua produção de glicoamilase é nitidamente melhor que dos ensaios $B 2 n$, porém situa-se intermediariamente em relação a estes e aos outros descontínuos alimentados. A hipótese mais aceita para explicar a baixa produção é que a verdadeira causa do incremento na síntese de enzima nos ensaios descontínuos alimentados é a capacidade de manter a glicose (repressora) em níveis muito baixos durante o início do cultivo, quando as células estão se adaptando e preparando seu metabolismo para o consumo do substrato a elas apresentado. Isto se embasa também no fato do ensaio F2H mostrar um desempenho tão bom como o F24.

Numa visão geral, temos que nos ensaios fed-batch sempre se obteve altas atividades quando se iniciou a alimentação com 4 horas de cultivo, mesmo com o hidrolisado. A performance piorou quando se alimentou desde o início, mesmo observando-se nítida indução, o que não é vista nos outros descontínuos alimentados. Este ensaio apresenta acúmulo de glicose maior no início, porém não tão pronunciado como nos descontínuos, o que leva a uma produção intermediária entre os batch e fed-batch.

Assim os resultados sugerem que o acúmulo de glicose e portanto o efeito repressivo é de fundamental importância, e igualmente é fundamental que o acúmulo de glicose ocorra o mais tarde possível.

Desta análise, pode-se definir outros ensaios que deveriam em sequência ser feitos, para se confirmar estas hipóteses. A repetição do 
ensaio com hidrolisado e do ensaio alimentado desde o início, assim como um ensaio alimentado com xarope hidrolisado desde o início, parecem ser importantes. Também o emprego de fontes de carbono, como amido e glicose, com grau p.a. acrescentariam importantes informações. Por fim pode-se analisar a influência de um deslocamento do acúmulo de glicose, através de ensaios alimentados a partir de, por exemplo, 0, 2, 4, 6 e 8 horas de cultivo. 


\subsection{Ensaios Descontínuos Alimentados a $S_{0}=40 \mathrm{~g} / 1$}

Após estudo através de diversos ensaios a $S_{0}=20 \mathrm{~g} /$, mostrou-se interessante comparar os resultados em situações onde se ofereça maior quantidade total de ART ao microrganismo. Apesar de não se ter monitoração da concentração de oxigênio dissolvido, sabe-se (Fachini, 1988) que nos ensaios anteriores a transferência de oxigênio para o meio de cultura é suficiente para não se ter limitação pela concentração de oxigênio dissolvido. Ao se elevar St, a massa total de células deve aumentar para cerca de $12 \mathrm{~g} / \mathrm{A}$ e em certos momentos, nas condições utilizadas de transferência de oxigênio (frequência de agitação de 700 rpm e aeração de $1 \mathrm{vvm}$ ), a concentração de oxigênio dissolvido cai abaixo da concentração crítica (Fachini, 1988). Nestas condições, o processo descontínuo alimentado se apresenta como uma forma de contornar este problema, por permitir que se limite a oferta de substrato ao microrganismo e com isso diminuir a velocidade específica de respiração (QO2).

Os ensaios realizados a $S_{0}=40 \mathrm{~g} / \mathrm{g}$ guardam estreita relação com os realizados a $S_{0}=20 \mathrm{~g} / \mathrm{l}$, pois se procurou manter as mesmas fs. $\mathrm{Na}$ prática, isso significa que até o final da alimentação nos ensaios F2n, esses deveriam se comportar igualmente aos $\mathrm{F} 4 \mathrm{n}$, visto que o microrganismo não tem capacidade de "enxergar" (ou "imaginar") por quanto tempo ainda haverá suplementação de substrato.

Para os F41 e F43, executados primeiramente, optou-se pelas 2 vazões mássicas de alimentação extremas: fs $=14,5$ e 32,2 gART/h, respectivamente, assemelhando-se aos ensaios F21 e F24 (13,3 e 32,1 
gART/h). Os resultados destes ensaios estão mostrados nas Figuras 4.15 e 4.16.

Observa-se que em F41 houve limitação por substrato das 20 às 30 horas de cultivo, período no qual ainda havia alimentação, porém não suficiente para suprir o consumo microbiano. Cabe esclarecer, que neste ensaio, no instante $26 \mathrm{~h}$, há um pequeno aumento pontual em S e G, devido a um erro de operação da bomba de alimentação, mas logo corrigido, como se observa na amostra seguinte, onde todo o substrato já havia sido consumido.

Provavelmente pela falta de substrato, entre os ensaios a $S_{0}=40 \mathrm{~g} / 1$ é este o que apresenta menor crescimento celular, inclusive comparados aos ensaios descontínuos B41 e B42 análogos, com Xm = $11,0 \mathrm{~g} / \mathrm{l}, \mathrm{YX} / \mathrm{S}=0,24 \mathrm{~g} / \mathrm{g}$ e $\mathrm{PX}=0,45 \mathrm{~g} / \mathrm{h} \mathrm{h}$. A síntese enzimática esteve ligeiramente prejudicada, apresentando $\mathrm{Am}=2477 \mathrm{U} / \mathrm{l}$ em 30 horas de cultivo. Mesmo assim, convém lembrar que este valor ainda é 17\% superior ao dos ensaios descontínuos (2111 U/1). As Tabelas 4.12 e 4.13 apresentam os valores dos fatores de conversão e produtividades dos quatro ensaios descontínuos alimentados a $S_{0}=40 \mathrm{~g} / \mathrm{h}$, de modo a facilitar sua comparação. 
Tabela 4.12 Grandezas usadas no cálculo de fatores de conversão e produtividades para os ensaios F41, F42, F43 e F4H.

\begin{tabular}{|cccccccc|}
\hline Ensaio & $\begin{array}{c}\mathrm{S}_{\mathbf{0}} / \mathrm{St} \\
(\mathrm{g} / \mathrm{l})\end{array}$ & $\begin{array}{c}\mathrm{tX} \\
(\mathrm{h})\end{array}$ & $\begin{array}{c}\mathrm{Xo} \\
(\mathrm{g} / \mathrm{l})\end{array}$ & $\begin{array}{c}\mathrm{Xm} \\
(\mathrm{g} / \mathrm{l})\end{array}$ & $\begin{array}{c}\mathrm{tA} \\
(\mathrm{h})\end{array}$ & $\begin{array}{c}\text { Ao } \\
(\mathrm{U} / 1)\end{array}$ & $\begin{array}{c}\text { Am } \\
(\mathrm{U} / \mathrm{l})\end{array}$ \\
$\mathrm{F} 41$ & 44,7 & 24 & 0,17 & 11,03 & 30 & 21 & 2477 \\
$\mathrm{~F} 42$ & 42,3 & 24 & 0,20 & 12,14 & 27 & 20 & 2338 \\
$\mathrm{~F} 43$ & 44,7 & 27 & 0,33 & 13,31 & 27 & 24 & 2988 \\
F4H & 42,3 & 27 & 0,29 & 12,67 & 30 & 21 & 2775 \\
\hline
\end{tabular}

Tabela 4.13 Grandezas calculadas: fatores de conversão e produtividades para os ensaios F41, F42, F43 e F4H.

\begin{tabular}{|ccccc|}
\hline Ensaio & $\begin{array}{c}\text { YX/S } \\
(\mathrm{g} / \mathrm{g})\end{array}$ & $\begin{array}{c}\text { PX } \\
(\mathrm{g} / \mathrm{h} / \mathrm{h})\end{array}$ & $\begin{array}{c}\text { YA/S } \\
(\mathrm{U} / \mathrm{g})\end{array}$ & $\begin{array}{c}\text { PA } \\
(\mathrm{U} / \mathrm{h} / \mathrm{h})\end{array}$ \\
F41 & 0,24 & 0,45 & 54 & 81 \\
F42 & 0,28 & 0,50 & 54 & 85 \\
F43 & 0,29 & 0,48 & 66 & 109 \\
F4H & 0,29 & 0,46 & 65 & 91 \\
\hline
\end{tabular}



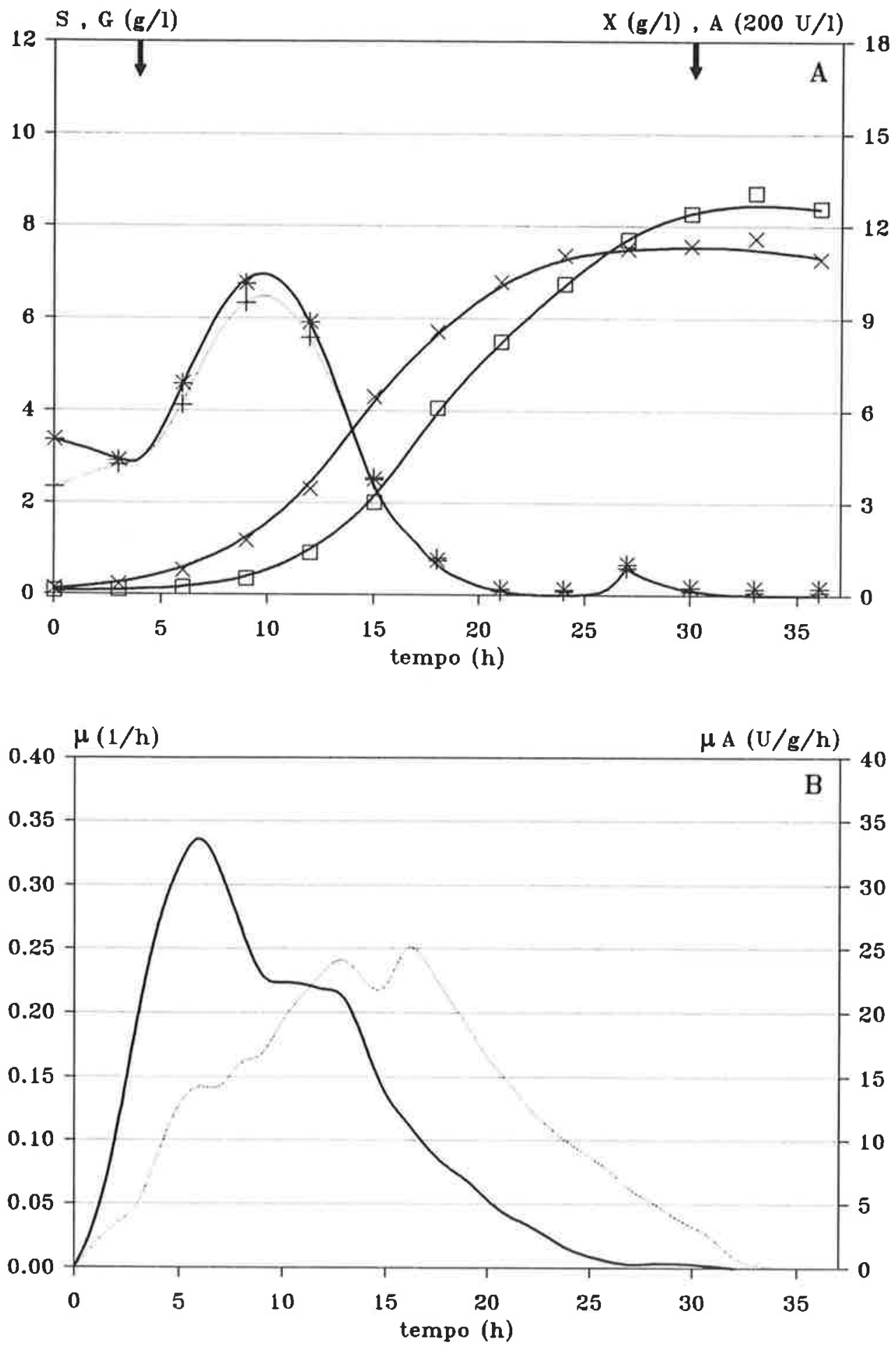

Figura 4.15 Resultados obtidos no ensaio F41 (fed-batch, $40 \mathrm{~g} / \mathrm{l}$, fs $=14,5$ gART/h).

A) Concentração de ART (S) $\left({ }^{*}\right)$, glicose $(G)(+)$, células $(X)(X)$ e atividade enzimática (A) (a) (as setas indicam o inicio e o final da alimentação)

B) Velocidades específicas de crescimento $(\mu)(-$ e produção de enzima $(\mu \mathrm{A})(-\cdot-)$ 

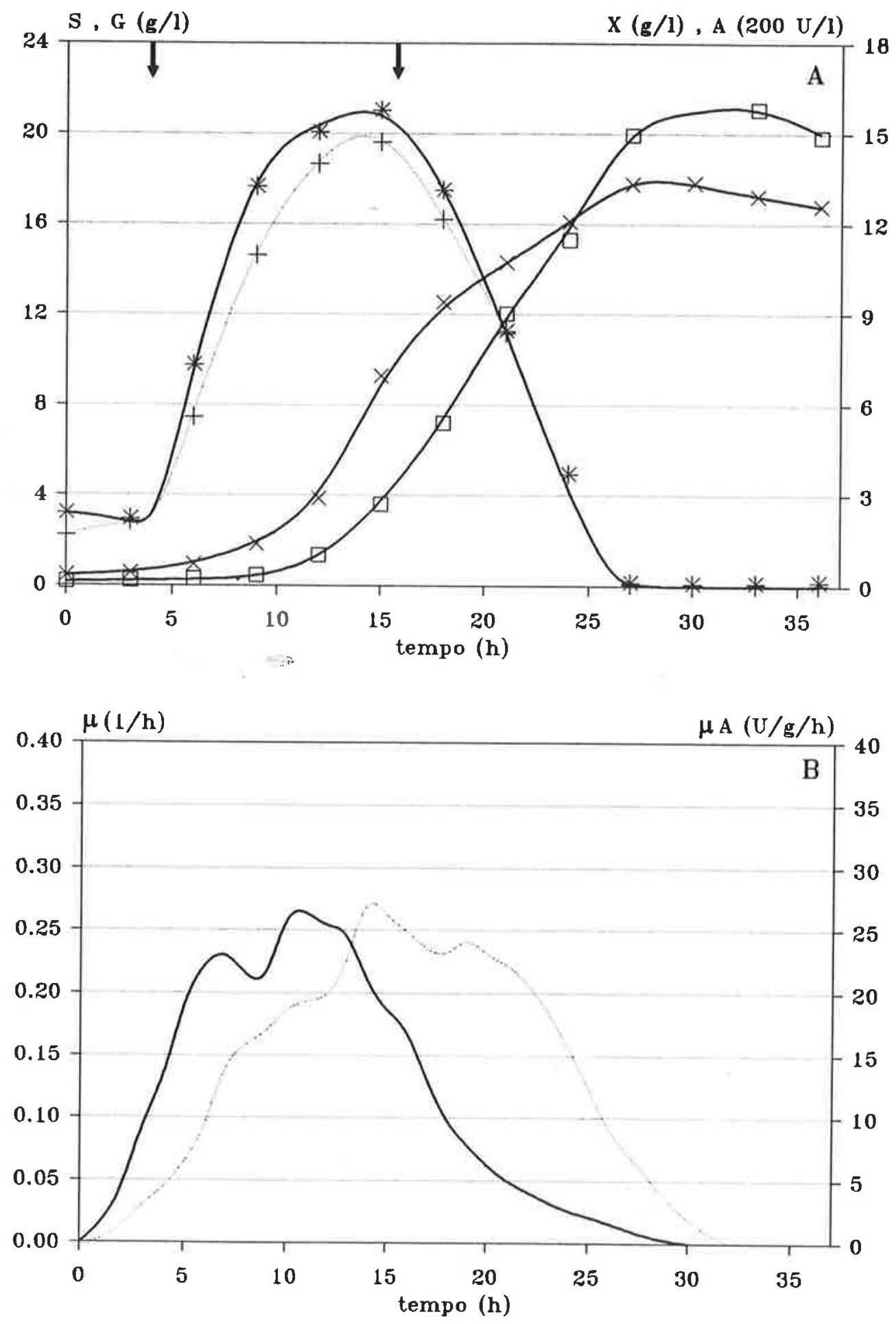

Figura 4.16 Resultados obtidos no ensaio F43 (fed-batch, $40 \mathrm{~g} / \mathrm{l}$, fs $=32,2$ gART $/ \mathrm{h}$ ).

A) Concentração de ART (S) $\left(^{\star}\right)$, glicose $(G)(+)$, células $(X)(X)$ e atividade enzimática (A) (a) (as setas indicam o início e o final da alimentação)

B) Velocidades específicas de crescimento $(\mu)(-)$ e produção de enzima $(\mu \mathrm{A})(--\cdot)$ 
O ensaio F43 por outro lado apresentou um excesso de substrato, sendo comparável até as 10 horas de cultivo ao ensaio F24, que atingiu cerca de 18 gART/1 neste instante. Como sua alimentação continuou por mais 6 horas, $S$ se elevou até o patamar de $21 \mathrm{~g} / 1$ com 15 horas de cultivo, quando a alimentação passou a não mais compensar o consumo microbiano pelo elevado número de células (cerca de $7 \mathrm{~g} / \mathrm{l}$ ). 0 resultado do crescimento celular foi superior aos demais ensaios, atingindo $\mathrm{Xm}=13,3 \mathrm{~g} / \mathrm{l}$, e consequentemente $\mathrm{YX} / \mathrm{S}=0,29 \mathrm{~g} / \mathrm{g}$ e $\mathrm{PX}=0,48 \mathrm{~g} / \mathrm{l} / \mathrm{h}$. Quanto à síntese de glicoamilase, este é o ensaio que melhor resultou, chegando a quase $3000 \mathrm{U} / \mathrm{l}$, ou seja, 42\% superior aos descontínuos. Também se chegou ao maior YA/S (66 U/g) e PA (110 U///h). Provavelmente, a alta produção de enzima neste ensaio deve-se ao fato de ter ocorrido indução à síntese pela presença de polissacarídeos por longo período, até cerca de 20 horas de cultivo. Em nenhum outro ensaio deste trabalho pôde-se observar tão clara distinção entre as curvas de ART e glicose, em especial após a concentração celular atingir altos valores. A curva de velocidade específica de produção de enzima corrobora esta análise, pois nela se observa que $\mu \mathrm{A}$ manteve-se entre 15 e $25 \mathrm{U} / \mathrm{g} / \mathrm{h}$ de 4 a 24 horas de cultivo.

Como última semana de ensaios, foram realizados $F 42$ e $F 4 H$, cujos resultados são apresentados nas Figuras 4.17 e 4.18. 

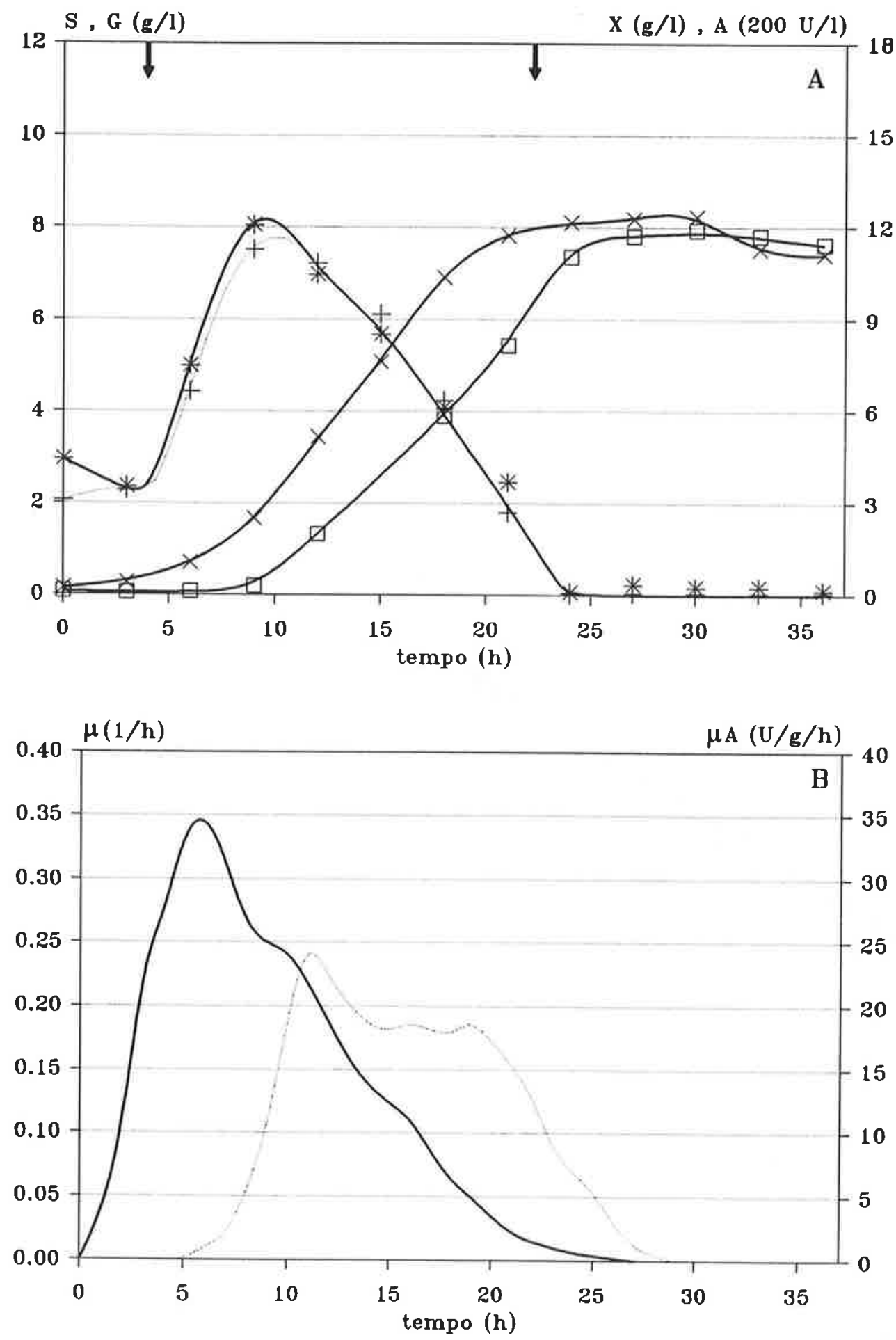

Figura 4.17 Resultados obtidos no ensaio F42 (fed-batch, $40 \mathrm{~g} /$, fs $=20,8 \mathrm{gART} / \mathrm{h}$ ).

A) Concentração de ART (S) (*), glicose $(G)(+)$, células $(X)(X)$ e atividade enzimática (A) (a) (as setas indicam o início e o final da alimentação)

B) Velocidades específicas de crescimento $(\mu)(-)$ e produção de enzima $(\mu \mathrm{A})(-\cdot-)$ 

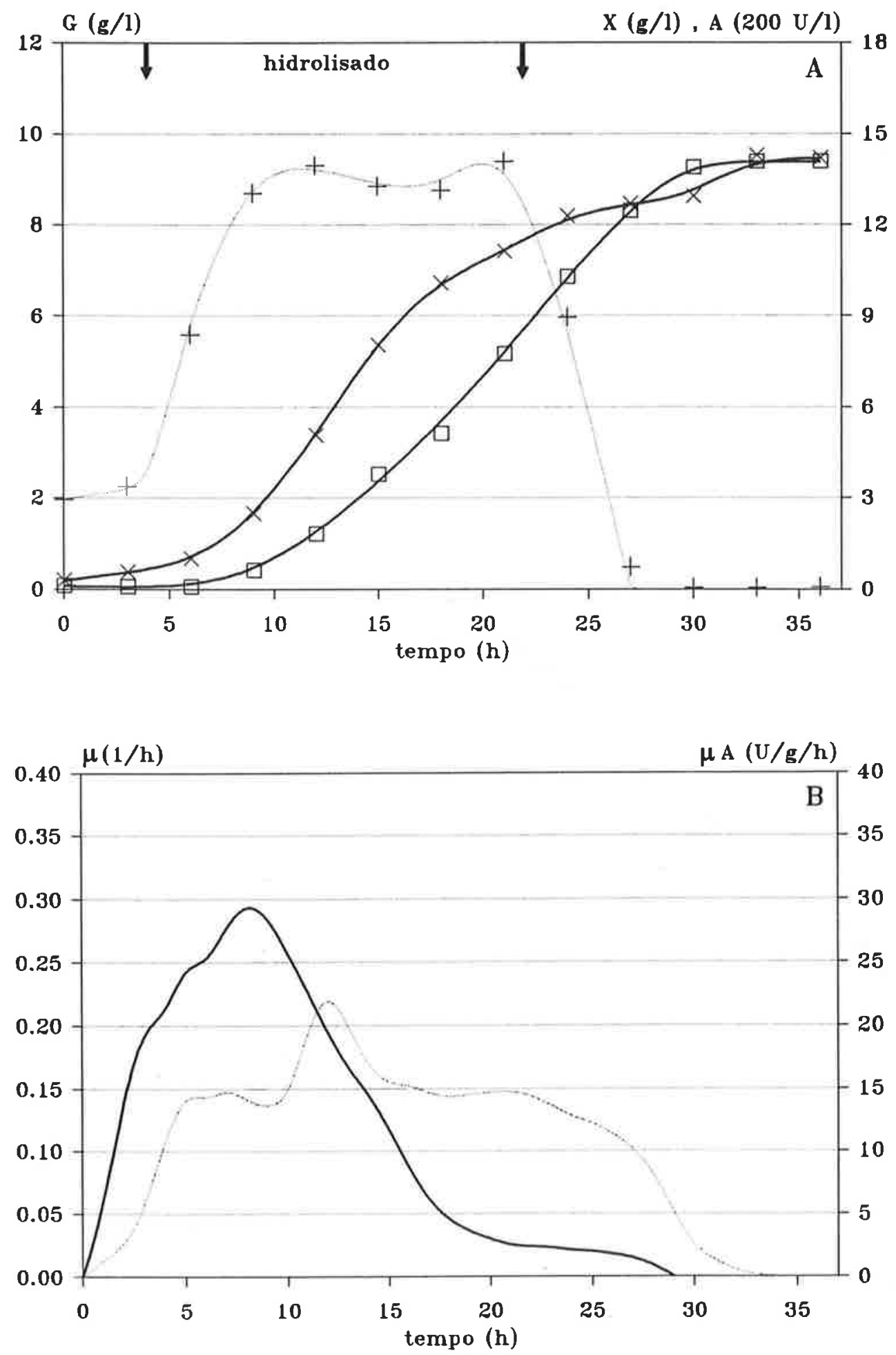

Figura 4.18 Resultados obtidos no ensaio F4H (fed-batch, $40 \mathrm{~g} /$, fs $=21,1 \mathrm{gART} / \mathrm{h}$, xarope hidrolisado).

A) Concentração de glicose $(\mathrm{G})(+)$, células $(\mathrm{X})(\mathrm{X}) \mathrm{e}$ atividade enzimática (A) () (as setas indicam o início e o final da alimentaç̃o)

B) Velocidades especificas de crescimento ( $\mu$ ) (-) e produção de enzima $(\mu \mathrm{A})(-\cdot)$ 
O ensaio F42 foi idealizado, imaginando-se que a vazão mássica de alimentação do ensaio F43 (fs=32,2 gART/h) tenha sido demasiadamente elevada, ocasionando grande acúmulo de glicose com 15 horas de cultivo. Optou-se por uma vazão intermediária entre a de F22 e F23, 20,8 gART/h. Na realidade, buscava-se repetir a elevação na atividade enzimática proporcionada pelos ensaios descontínuos alimentados, com $S_{0}=20 \mathrm{~g} /$, isto é, em ensaios realizados com menor $S_{0}$ conseguiu-se dobrar Am em relação aos ensaios descontínuos, enquanto que com $S_{0}=40 \mathrm{~g} / 1$ o melhor resultado indicava $A m$ somente 42 \% superior aos $\mathrm{B} 4 \mathrm{n}$.

Paralelamente, executou-se $\mathrm{F} 4 \mathrm{H}$, com fs semelhante a F42, de modo a se tentar confirmar as conclusões feitas com base no ensaio F2H.

No entanto, a análise das Tabelas 4.12 e 4.13, agrupando todos os ensaios descontínuos alimentados a $40 \mathrm{~g} / \mathrm{l}$, mostra que é a vazão de alimentação de F43 que proporciona melhores resultados.

Comparando-se $F 42$ e $F 4 H$, observa-se que há uma grande diferença no perfil da glicose ao longo do tempo. Não só $F 4 H$ atinge valores superiores (acima de $9 \mathrm{~g} / \mathrm{l}$, em relação à pontualmente $8 \mathrm{~g} / \mathrm{lem}$ F42), como se mantém alto por várias horas, até quase 25 horas de cultivo. Novamente, esse comportamento não era esperado, e pode encontrar explicação em algum fator não analisado na forma com a qual o xarope hidrolisado é preparado. Com relação a curva de $X_{1}$ nenhuma diferença se observa em comparação a F42. As duas últimas medidas (com $t=33$ e $36 \mathrm{~h}$ ) apresentam valores atípicos, não tendo inclusive sido utilizadas na determinação de YX/S e PX. 
A atividade enzimática no ensaio $\mathrm{F} 4 \mathrm{H}$ comportou-se semelhante à de F42 até cerca de 25 horas de cultivo, porém elevou-se acima deste no final do ensaio, atingindo 2775 (U/1), $19 \%$ superior. Isso pode ser observado, nas Figuras 4.17 e 4.18, com relação à velocidade específica de síntese de glicoamilase, que no ensaio F4H se mantém entre 10 e 15 $\mathrm{U} / \mathrm{g} / \mathrm{h}$ até 27 horas de cultivo (em relação à $\mathrm{F} 42,21 \mathrm{~h}$ ).

Dessa análise dos ensaios descontínuos alimentados a $S_{0}=40 \mathrm{~g} / \mathrm{l}$, observa-se que não se obteve nesses, resultados tão superiores aos descontínuos, como se obteve a $20 \mathrm{~g} / \mathrm{l}$. Mesmo assim, não se torna desprezível a melhora na produção de glicoamilase, visto que se obtiveram aumentos de $42 \%$ na atividade máxima, de $50 \%$ na produtividade e de $38 \%$ no fator de conversão substrato a enzima.

Os resultados dos ensaios descontínuos alimentados a $S_{0}$ de 40 g/ sugerem, então, que nesta concentração de ART o efeito repressivo não é mais o principal fator regulador da síntese de glicoamilase, e a efetiva indução por polissacarideos torna-se preponderante, tanto nos ensaios batch como fed-batch, aumentando substancialmente a produção. Dessa forma, não se obtém nos ensaios descontínuos alimentados uma elevação tão acentuada na produção de glicoamilase, pois mesmo o ensaio descontínuo já é capaz de oferecer suficiente indução ao microrganismo. 


\subsection{Discussão final}

Para facilidade de uma visão do conjunto de ensaios, na procura de conclusões, os vários valores de produtividade e fatores de conversão já apresentados são aqui repetidos, bem como os resultados experimentais que os geraram, nas Tabela 4.14 e 4.15.

O trabalho, conforme apresentado, em bloco de ensaios, permite gradualmente que se levante análises gerais, e na medida do possível, foram já levantadas.

De uma forma geral, e particularmente no estudo dos fenômenos de indução e repressão, pode-se ter certeza da validade do processo descontínuo alimentado na síntese de glicoamilase, ao menos nas condições estudadas de $S_{0}$, microrganismo, etc. Resumidamente, obteve-se nos ensaios descontínuos alimentados em relação aos ensaios batch, a $S_{0}$ de $20 \mathrm{~g} /$, resultados $96 \%$ superiores com relação ao fator de conversão substrato a enzima e $113 \%$ com relação à produtividade em enzima. Já os resultados a $S_{0}$ de $40 \mathrm{~g} / \mathrm{l}$ foram apenas 25 e 26\%, respectivamente, superiores aos dos ensaios descontínuos.

Aparentemente, com o aumento da concentração inicial de substrato, outras conclusões poderão ser tomadas, em especial, em relação a indução e repressão. 0 uso de fontes alternativas de carbono se apresenta como importante mecanismo de estudo do processo.

Com relação à variabilidade dos ensaios, convém lembrar que em qualquer processo biológico, em especial quando se trabalha com matérias primas naturais, há uma série de fatores relevantes, que não se tem controle ao realizar os ensaios. No entanto, este trabalho mostra 
ainda, validade no sentido de ponderar fatores influentes e alertar para o perigo de conclusões precipitadas, a partir de poucos dados. 
Tabela 4.14 Grandezas usadas no cálculo de fatores de conversão e produtividades para os diversos ensaios.

\begin{tabular}{|cccccccc|}
\hline Ensaio & $\begin{array}{c}\mathrm{S}_{\mathbf{0}} / \mathrm{St} \\
(\mathrm{g} / \mathrm{l})\end{array}$ & $\begin{array}{c}\mathrm{tX} \\
(\mathrm{h})\end{array}$ & $\begin{array}{c}\mathrm{X} \\
(\mathrm{g} / \mathrm{l})\end{array}$ & $\begin{array}{c}\mathrm{Xm} \\
(\mathrm{g} / \mathrm{l})\end{array}$ & $\begin{array}{c}\mathrm{tA} \\
(\mathrm{h})\end{array}$ & $\begin{array}{c}\text { Ao } \\
(\mathrm{U} / 1)\end{array}$ & $\begin{array}{c}\text { Am } \\
(\mathrm{U} / \mathrm{l})\end{array}$ \\
$\mathrm{B} 21$ & 23,1 & 18 & 0,25 & 8,42 & 18 & 42 & 653 \\
B22 & 24,1 & 20 & 0,32 & 8,01 & 24 & 34 & 512 \\
B23 & 20,7 & 22 & 0,48 & 8,60 & 24 & 34 & 580 \\
B24 & 21,5 & 22 & 0,30 & 8,83 & 22 & 18 & 507 \\
B41 & 44,7 & 24 & 0,29 & 12,27 & 27 & 20 & 2134 \\
B42 & 42,3 & 30 & 0,27 & 12,20 & 30 & 23 & 2088 \\
F21 & 24,1 & 16 & 0,23 & 8,76 & 22 & 36 & 1112 \\
F22 & 23,1 & 18 & 0,34 & 8,79 & 20 & 38 & 1255 \\
F23 & 23,1 & 16 & 0,31 & 8,70 & 20 & 44 & 1219 \\
F24 & 24,1 & 18 & 0,34 & 8,89 & 20 & 34 & 1057 \\
F2H & 20,7 & 18 & 0,47 & 10,11 & 22 & 37 & 1220 \\
F2I & 20,7 & 18 & 0,52 & 9,00 & 20 & 38 & 752 \\
F41 & 44,7 & 24 & 0,17 & 11,03 & 30 & 21 & 2477 \\
F42 & 42,3 & 24 & 0,20 & 12,14 & 27 & 20 & 2338 \\
F43 & 44,7 & 27 & 0,33 & 13,31 & 27 & 24 & 2988 \\
F4H & 42,3 & 27 & 0,29 & 12,67 & 30 & 21 & 2775 \\
\hline
\end{tabular}


Tabela 4.15 Grandezas calculadas: fatores de conversão e produtividades para os vários ensaios.

\begin{tabular}{|ccccc|}
\hline Ensaio & $\begin{array}{c}\mathrm{YX} / \mathrm{S} \\
(\mathrm{g} / \mathrm{g})\end{array}$ & $\begin{array}{c}\mathrm{PX} \\
(\mathrm{g} / \mathrm{h} / \mathrm{h})\end{array}$ & $\begin{array}{c}\mathrm{YA} / \mathrm{S} \\
(\mathrm{U} / \mathrm{g})\end{array}$ & $\begin{array}{c}\mathrm{PA} \\
(\mathrm{U} / \mathrm{h} / \mathrm{h})\end{array}$ \\
B21 & 0,35 & 0,45 & 26 & 33 \\
B22 & 0,32 & 0,38 & 20 & 19 \\
B23 & 0,39 & 0,37 & 26 & 23 \\
B24 & 0,40 & 0,39 & 23 & 22 \\
B41 & 0,27 & 0,50 & 47 & 78 \\
B42 & 0,28 & 0,40 & 49 & 68 \\
F21 & 0,35 & 0,53 & 44 & 48 \\
F22 & 0,37 & 0,47 & 52 & 60 \\
F23 & 0,36 & 0,52 & 50 & 58 \\
F24 & 0,35 & 0,48 & 42 & 51 \\
F2H & 0,47 & 0,54 & 57 & 53 \\
F2I & 0,41 & 0,47 & 34 & 35 \\
F41 & 0,24 & 0,45 & 54 & 81 \\
F42 & 0,28 & 0,50 & 54 & 85 \\
F43 & 0,29 & 0,48 & 66 & 109 \\
F4H & 0,29 & 0,46 & 65 & 91 \\
\hline
\end{tabular}




\subsubsection{Velocidades Específicas Máximas de Crescimento}

Outra forma de se analisar o comportamento cinético de crescimento microbiano é através da análise de gráficos mono-log da concentração celular em função do tempo. Como visto no item 3.5.1, a velocidade específica de crescimento $(\mu)$ pode ser graficamente visualizada, como a tangente da curva $\ln \mathrm{X}=\mathrm{f}(\mathrm{t})$, expressa pela Equação 3.6.

Assim, são apresentadas nas Figuras 4.19, 4.20, 4.21 e 4.22, os gráficos mono-log da concentração celular em função do tempo em todos os ensaios realizados neste trabalho.

Ainda segundo item 3.5.1, pela Equação 3.7, observa-se que no período de tempo em que as curvas de $\ln X=f(t)$ se apresentam alinhadas, têm-se $\mu_{m a ́ x}$. Dessa forma, calculou-se a regressão linear de lnX em função do tempo, nos intervalos em que se observa $\mu_{\text {máx }}$ A Tabela 4.16 apresenta os resultados obtidos deste cálculo em todos os ensaios, a fim de uma análise comparativa.

A média das velocidades específicas máxima de crescimento dos ensaios descontínuos a $S_{0}$ de $20 \mathrm{~g} / \mathrm{l}$ foi de $0,257 \mathrm{~h}^{-1}$, enquanto que para os ensaios descontínuos alimentados foi de $0,292 \mathrm{~h}^{-1}, 14 \%$ superior. Descontado o ensaio F2I, significativamente inferior, tem-se a média de $0,301 \mathrm{~h}^{-1}$ (17\% superior). Da mesma forma, a $S_{0}$ de $40 \mathrm{~g} / \mathrm{l}$, obteve-se média de $0,266 \mathrm{~h}^{-1}$ para os ensaios descontínuos e $0,273 \mathrm{~h}^{-1}$, apenas $3 \%$ superior. 

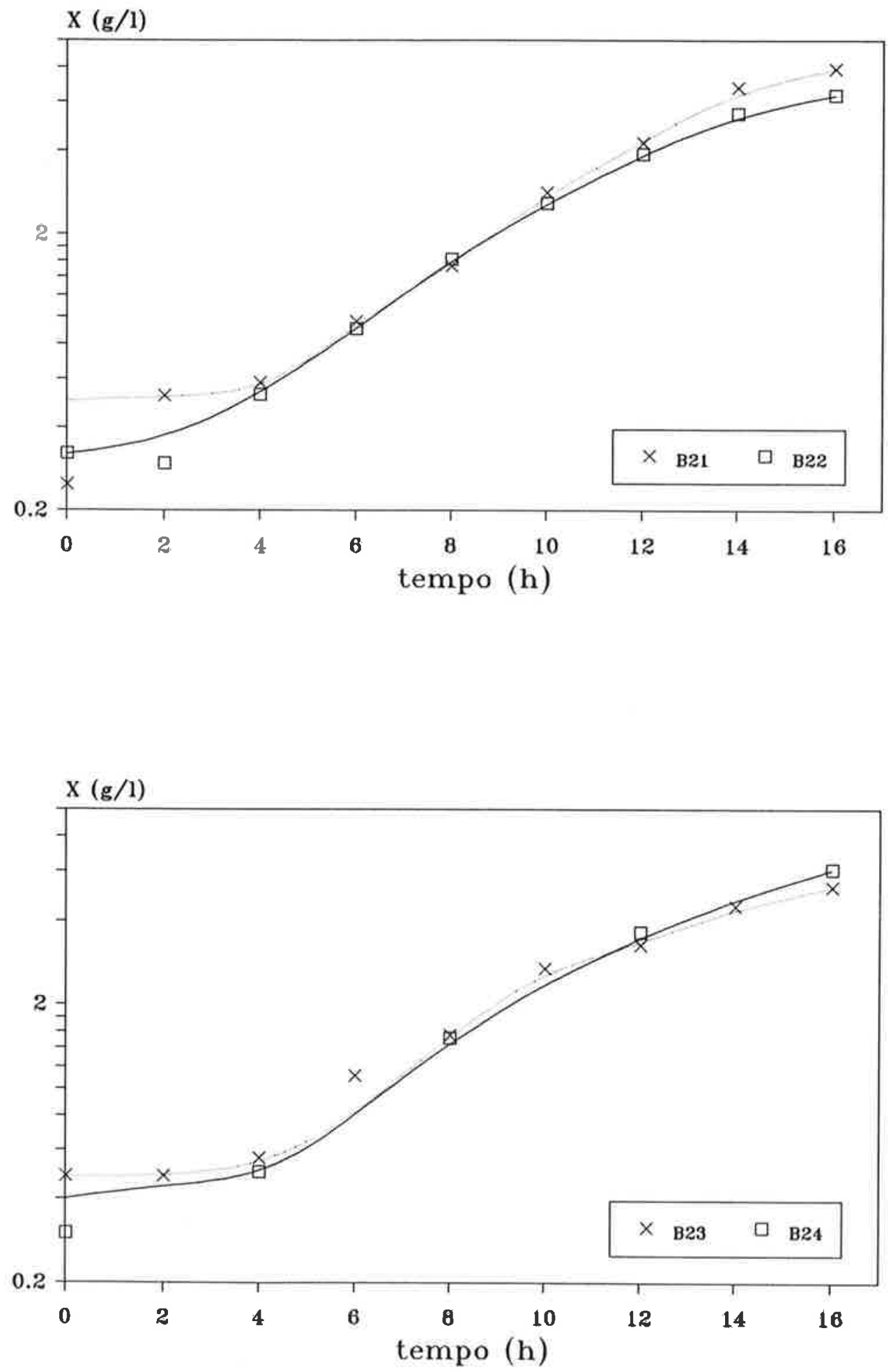

Figura 4.19 Concentração celular $(X)$ em função do tempo, em gráfico mono-log, para os ensaio B21, B22, B23 e B24. 

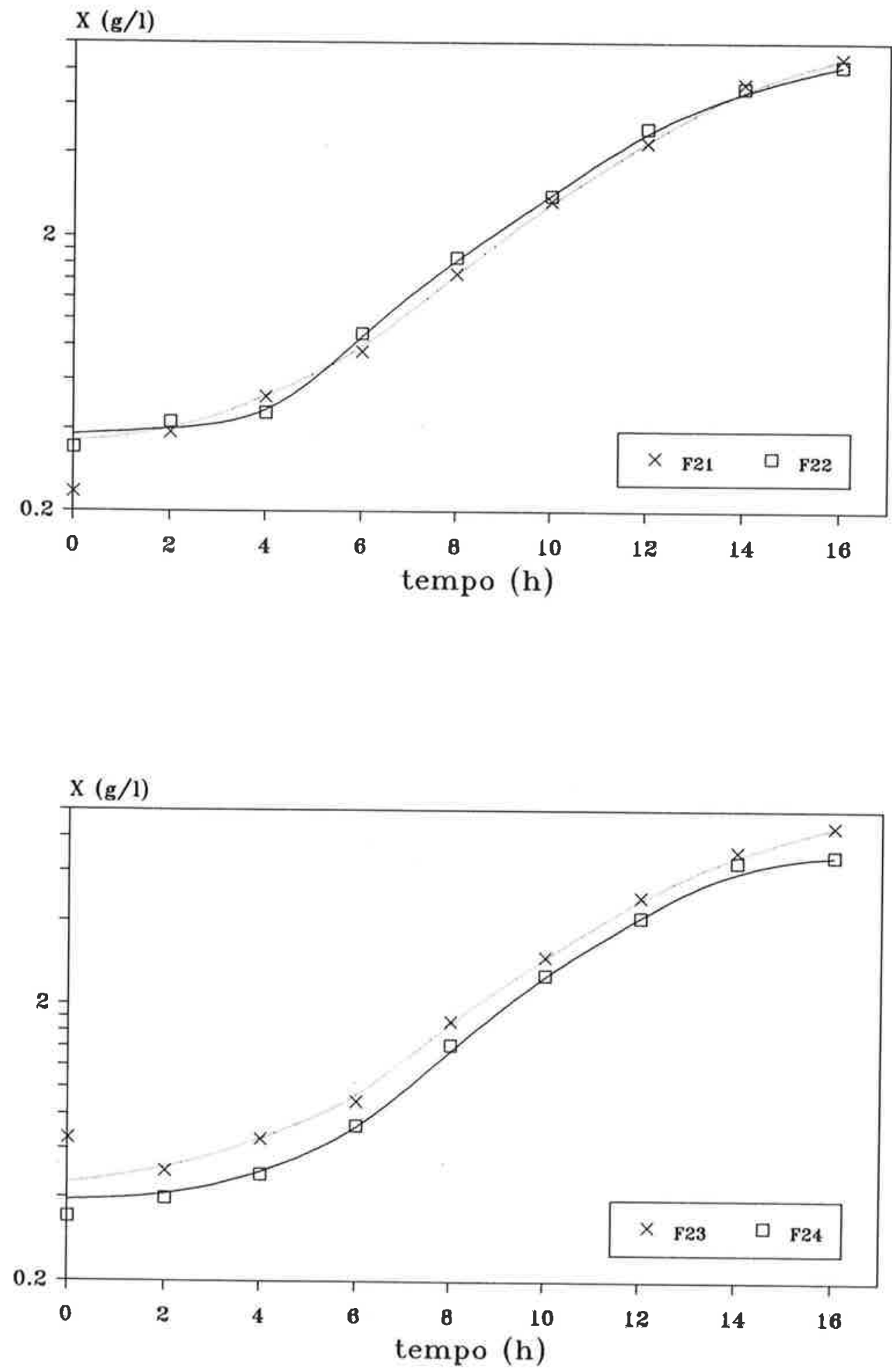

Figura 4.20 Concentração celular (X) em função do tempo, em gráfico mono-log, para os ensaio F21, F22, F23 e F24. 

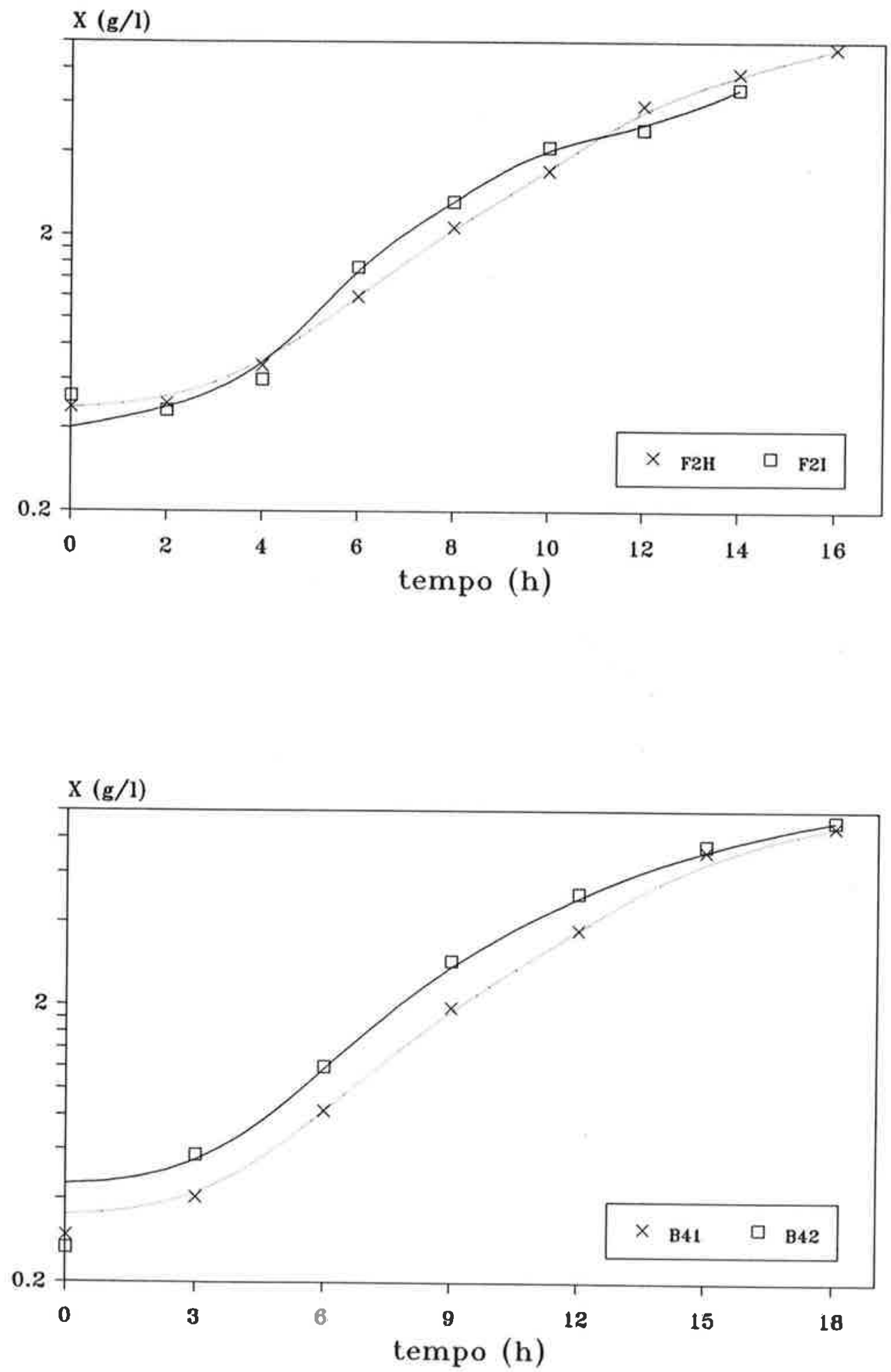

Figura 4.21 Concentração celular (X) em função do tempo, em gráfico mono-log, para os ensaio F2H, F2I, B41 e B42. 

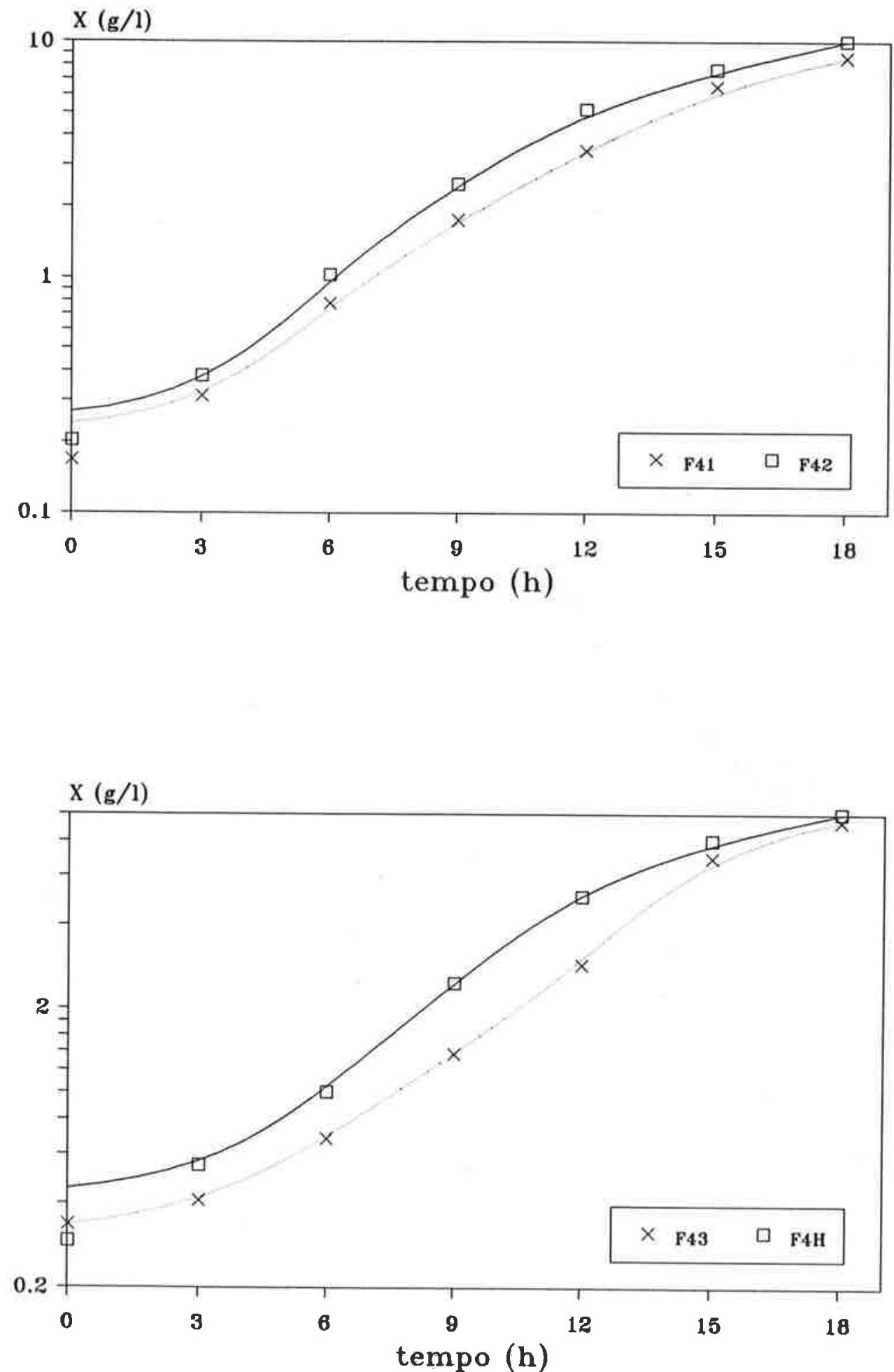

Figura 4.22 Concentração celular (X) em função do tempo, em gráfico mono-log, para os ensaio F41, F42, F43 e F4H. 
Tabela 4.16 Fase exponencial de crescimento celular dos ensaios realizados

\begin{tabular}{|c|c|c|c|}
\hline Ensaio & $\begin{array}{c}\text { Fase } \\
\text { Exponencial } \\
\text { (inicio a fim) } \\
\text { (h) }\end{array}$ & $\begin{array}{c}\mu_{\operatorname{máx}} \\
\left(h^{-1}\right)\end{array}$ & $\begin{array}{l}\text { Coeficiente } \\
\text { de } \\
\text { Correlação } \\
\text { (R) }\end{array}$ \\
\hline B21 & 4 a 10 & 0,260 & 0,9994 \\
\hline B22 & 4 a 10 & 0,268 & 0,998 \\
\hline B23 & 4 a 10 & 0,252 & 0,984 \\
\hline B24 & 4 a 12 & 0,249 & 0,996 \\
\hline B41 & 3 a 9 & 0,262 & 0,998 \\
\hline B42 & 3 a 9 & 0,269 & 0,998 \\
\hline F21 & 6 a 10 & 0,315 & 0,9994 \\
\hline F22 & 4 a 10 & 0,304 & 0,997 \\
\hline F23 & 6 a 10 & 0,301 & 0,997 \\
\hline F24 & 6 a 10 & 0,312 & 0,999 \\
\hline $\mathrm{F} 2 \mathrm{H}$ & 4 a 10 & 0,273 & 0,998 \\
\hline F2I & 6 a 10 & 0,249 & 0,997 \\
\hline F41 & 3 a 9 & 0,286 & 0,9991 \\
\hline F42 & 3 a 9 & 0,312 & 0,999 \\
\hline F43 & 6 a 12 & 0,240 & 0,9997 \\
\hline $\mathrm{F} 4 \mathrm{H}$ & 3 a 12 & 0,253 & 0,995 \\
\hline
\end{tabular}


De modo geral, observa-se que a variação na velocidade específica máxima de crescimento ao longo dos diferentes ensaios, é muito menor do que a observada em termos de fator de conversão substrato a enzima e produtividade em enzima. No entanto, algumas ponderações podem, ainda, ser feitas.

Numa primeira análise, ao se observar maiores $\mu_{\text {máx }}$ nos ensaios descontínuos alimentados a $S_{0}$ de $20 \mathrm{~g} / 1$ em relação aos descontínuos, se poderia levantar a hipótese de mesmo nesta concentração de ART já ocorrer alguma inibição ao crescimento por excesso de substrato e que o processo fed-batch limitaria a oferta de substrato e consequentemente a inibição.

Porém, quando se compara os $\mu_{\text {máx }}$ dos ensaios batch a $20 \mathrm{~g} / 1$ com os a $40 \mathrm{~g} /$, esta hipótese é desfeita. A média de $0,266 \mathrm{~h}^{-1}$ dos ensaios B41 e B42 é ligeiramente superior à $0,257 \mathrm{~h}^{-1}$ dos ensaios B21 a B24, não confirmando portanto, a idéia de existência de inibição por substrato.

Outra explicação, mais provável, para a maior velocidade específica máxima de crescimento dos ensaios descontínuos alimentados, se baseia em Pirt (1975), que afirma que uma das vantagens do processo fed-batch é a oferta parcelada de micronutrientes, evitando o consumo excessivo ou desperdício que causaria uma falta em instante posterior. Assim, os ensaios fed-batch permitiriam o microrganismo crescer sem a falta de certos fatores de crescimento, resultando em maior $\mu_{\text {máx. }}$

Ao se comparar os ensaios a $40 \mathrm{~g} /$, os descontínuos alimentados não apresentam $\mu_{\text {máx }}$ muito superior aos descontínuos. Sob a mesma 
hipótese acima citada, os fatores de crescimento não chegariam a fazer falta nos ensaios com maior quantidade de xarope, ao menos até o fim da fase exponencial de crescimento, em qualquer um dos dois processos estudados. Além disso, a concentração de oxigênio dissolvido, não medida nos ensaios deste trabalho, é, de ensaios realizados anteriormente, limitante para essa concentração de ART, podendo ser um fator importante na não obtenção de maiores $\mu_{\text {máx. }}$

0 ensaio F2I, alimentado desde o início do cultivo, comporta-se mais similarmente a um ensaio batch do que um ensaio descontínuo alimentado típico. Isto já foi observado em relação a vários aspectos, como perfil das curvas de ART e glicose ao longo do tempo e atividade enzimática máxima. Da mesma forma, com relação a $\mu_{\text {máx }}$ seu resultado é semelhante ao dos ensaios B2n do que aos outros descontínuos alimentados. Conforme dito, este fato deriva do instante de alimentação, pois logo após 6 horas de cultivo, toda a fonte de carbono já foi alimentada e ele se comporta como um ensaio descontínuo.

Por fim, ainda uma análise pode ser feita, com base na relação Am/Xm, ou atividade específica. A média dos ensaios descontínuos alimentados a $20 \mathrm{~g} / \mathrm{l}$, descontado F2I, $130 \mathrm{U} / \mathrm{g}$, é 94\% superior aos descontínuos (67 U/g), enquanto que a $40 \mathrm{~g} / \mathrm{l}$, os ensaios fed-batch apresentaram média (215 U/g) $24 \%$ acima dos batch (173 U/g). Ao se comparar este tipo de parâmetros, com o anteriormente citado, $\mu_{\text {máx }}$, observa-se grande coerência. À medida que $\mu_{\text {máx }}$ aumenta, ao se passar de ensaios batch para fed-batch ou de ensaios a $S_{0}$ de $20 \mathrm{~g} / \mathrm{para}$ ensaios a $40 \mathrm{~g} /, \mathrm{Am} / \mathrm{Xm}$ também aumenta, com certa 
proporcionalidade. Claro está que não se tem a priori os valores de $\mu_{m a ́ x}$ mas já existem alguns métodos de estimativa on-line de $X$, que permitiriam avaliar $\mu_{\text {máx }}$ no decorrer do cultivo. 


\section{CONCLUSOES}

Ao longo deste trabalho, várias discussões foram apresentadas, que permitem a proposição de uma série de conclusões, aqui relacionadas.

a) O crescimento celular, assim como a síntese de glicoamilase por Aspergillus awamori NRRL 3112, apresenta uma variabilidade entre ensaios repetidos.

b) A estabilidade da cepa, flutuações no preparo do meio de cultura e limitações na metodologia analítica são apresentados como principais responsáveis pela variabilidade.

c) Todos os ensaios descontínuos alimentados se mostraram melhores produtores de glicoamilase que os descontínuos, apresentando produtividade $113 \%$ superior na média dos ensaios com concentração total de ART de $20 \mathrm{~g} / \mathrm{l}$ e $26 \%$ superior nos ensaios a $S_{0}=40 \mathrm{~g} / \mathrm{l}$.

d) Nos ensaios com vazão mássica de alimentação (fs) muito baixa, se observou queda na produção. Obtiveram-se os melhores resultados nos ensaios com fs=17,1gART $/ \mathrm{h}$ a $S_{0}=20 \mathrm{~g} / \mathrm{l}$ e fs=32,2 a $40 \mathrm{~g} / 1$.

e) $O$ crescimento microbiano não apresentou alterações significativas, em especial, com relação aos valores finais de concentração celular. As velocidades específicas máximas de crescimento dos ensaios descontínuos alimentados a menor $\mathrm{S}_{0}$, foramem média $17 \%$ superiores aos batch. Tal elevação não se observou nos ensaios a $40 \mathrm{~g} / \mathrm{l}$. 
f) Nos ensaios a $20 \mathrm{~g} / \mathrm{h} \mathrm{em}$ que a alimentação se iniciou com 4 horas de cultivo, obteve-se o dobro de atividade enzimática máxima dos ensaios batch, mesmo com alimentação de xarope previamente hidrolisado.

g) No cultivo alimentado desde o início, não se observou igual atividade máxima.

h) Aparentemente, a baixas concentrações de ART, o efeito repressivo é o principal mecanismo de controle a síntese de glicoamilase por Aspergillus awamori e a indução por polissacrídeos não é relevante.

i) Nos cultivos com $S_{0}=40 \mathrm{~g} / 1$, pode-se supor que a repressão não é o mecanismo regulatório mais importante, e outros fenômenos como a indução passam a assumir o papel mais importante. 


\section{A- 1 RESULTADOS DOS ENSAIOS}

Tabela A.1 Concentração de ART (S), de glicose (G), de células (X) e atividade enzimática (A) em função do tempo para o ensaio B21 ( $1^{\circ}$ batch, 20g/1)

\begin{tabular}{|ccccc|}
\hline $\begin{array}{c}\text { tempo } \\
(\mathrm{h})\end{array}$ & $\begin{array}{c}\mathrm{S} \\
(\mathrm{g} / \mathrm{l})\end{array}$ & $\begin{array}{c}\mathrm{G} \\
(\mathrm{g} / \mathrm{l})\end{array}$ & $\begin{array}{c}\mathrm{X} \\
(\mathrm{g} / \mathrm{l})\end{array}$ & $\begin{array}{c}\mathrm{A} \\
(\mathrm{U} / \mathrm{M})\end{array}$ \\
23,1 & 5,3 & 0,25 & 41 \\
2 & 22,6 & 12,6 & 0,52 & 46 \\
4 & 20,8 & 17,3 & 0,58 & 50 \\
6 & 19,1 & 19,1 & 0,96 & 65 \\
8 & 19,0 & 18,2 & 1,53 & 103 \\
10 & 14,3 & 16,9 & 2,81 & 194 \\
12 & 12,3 & 12,8 & 4,23 & 340 \\
14 & 6,6 & 9,2 & 6,73 & 504 \\
16 & 2,5 & 2,6 & 7,84 & 618 \\
18 & 0,4 & 0,1 & 8,42 & 652 \\
20 & 0,2 & 0,1 & 8,16 & 659 \\
22 & 0,3 & 0,1 & 7,98 & 649 \\
24 & 0,1 & 0,1 & 7,69 & \\
26 & 0,2 & 0,1 & 7,07 & 683 \\
\hline
\end{tabular}


Tabela A.2 Valores de concentração celular (X) e atividade enzimática (A) considerados para o cálculo das velocidades específicas de crescimento $(\mu)$ e produção de enzima $\left(\mu_{A}\right)$ em função do tempo para o ensaio B21 ( $1^{\circ}$ batch, $\left.20 \mathrm{~g} / 1\right)$

\begin{tabular}{|ccccc|}
\hline $\begin{array}{c}\mathrm{t} \\
(\mathrm{h})\end{array}$ & $\begin{array}{c}\mathrm{X} \\
(\mathrm{g} / \mathrm{l})\end{array}$ & $\begin{array}{c}\mathrm{A} \\
(\mathrm{U} / \mathrm{l})\end{array}$ & $\begin{array}{c}\mu \\
(\mathrm{g} / \mathrm{g} / \mathrm{h})\end{array}$ & $\begin{array}{c}\mu_{\mathrm{A}} \\
(\mathrm{U} / \mathrm{g} / \mathrm{h})\end{array}$ \\
0 & 0,50 & 41 & 0,000 & 0,0 \\
1 & 0,51 & 42 & 0,020 & 4,0 \\
2 & 0,52 & 44 & 0,039 & 3,9 \\
3 & 0,54 & 46 & 0,037 & 4,6 \\
4 & 0,58 & 50 & 0,155 & $\mathbf{8 , 0}$ \\
5 & 0,71 & 57 & 0,211 & 11,3 \\
6 & 0,89 & 66 & 0,247 & 12,2 \\
7 & 1,16 & 80 & 0,276 & 15,6 \\
8 & 1,54 & 104 & 0,279 & 18,8 \\
9 & 2,08 & 141 & 0,322 & 20,1 \\
10 & 2,80 & 192 & 0,291 & 21,7 \\
11 & 3,75 & 258 & 0,267 & 19,5 \\
12 & 4,75 & 340 & 0,221 & 17,2 \\
13 & 5,80 & 425 & 0,172 & 15,5 \\
14 & 6,75 & 510 & 0,117 & 11,0 \\
15 & 7,40 & 575 & 0,074 & 7,3 \\
16 & 7,85 & 620 & 0,051 & 3,1 \\
17 & 8,20 & 640 & 0,030 & 1,5 \\
18 & 8,35 & 650 & 0,006 & 1,2 \\
19 & 8,35 & 655 & 0,000 & 0,0 \\
20 & 8,35 & 655 & 0,000 & 0,0 \\
21 & 8,35 & 655 & 0,000 & 0,0 \\
22 & $\mathbf{8}, 35$ & 655 & 0,000 & 0,0 \\
23 & $\mathbf{8 , 3 5}$ & 655 & 0,000 & 0,0 \\
24 & 8,35 & 655 & 0,000 & 0,0 \\
25 & 8,35 & 655 & 0,000 & 0,0 \\
26 & 8,35 & 655 & 0,000 & 0,0 \\
\hline
\end{tabular}


Tabela A.3 Concentração de ART (S), de glicose (G) de células (X) e atividade enzimática $(A)$ em função do tempo para o ensaio $B 22\left(2^{\circ}\right.$ batch, $\left.20 \mathrm{~g} / \mathrm{l}\right)$

\begin{tabular}{|ccccc|}
\hline $\begin{array}{c}\text { tempo } \\
(\mathrm{h})\end{array}$ & $\begin{array}{c}\mathrm{S} \\
(\mathrm{g} / \mathrm{l})\end{array}$ & $\begin{array}{c}\mathrm{G} \\
(\mathrm{g} / \mathrm{1})\end{array}$ & $\begin{array}{c}\mathrm{X} \\
(\mathrm{g} / \mathrm{A})\end{array}$ & $\begin{array}{c}\mathrm{A} \\
(\mathrm{U} / \mathrm{1})\end{array}$ \\
0 & 24,1 & 5,7 & 0,32 & 33 \\
2 & 24,0 & 10,9 & 0,29 & 38 \\
4 & 23,0 & 16,5 & 0,52 & 39 \\
6 & & 19,6 & 0,90 & 54 \\
8 & 21,3 & 19,6 & 1,61 & 90 \\
10 & 17,8 & 18,0 & 2,58 & \\
12 & 13,4 & 14,7 & 3,86 & 302 \\
14 & 10,4 & 9,4 & 5,41 & 387 \\
16 & 7,1 & 7,0 & 6,32 & 426 \\
18 & 3,5 & 3,5 & 7,49 & 425 \\
20 & 0,3 & 0,3 & 8,01 & 477 \\
22 & 0,1 & 0,1 & 8,31 & 471 \\
24 & 0,1 & 0,1 & 8,05 & 511 \\
26 & 0,1 & 0,1 & 7,87 & 511 \\
\hline
\end{tabular}


Tabela A.4 Valores de concentração celular (X) e atividade enzimática (A) considerados para o cálculo das velocidades específicas de crescimento $(\mu)$ e produção de enzima $\left(\mu_{A}\right)$ em função do tempo para o ensaio B22 ( $2^{\circ}$ batch, $\left.20 \mathrm{~g} / \mathrm{A}\right)$

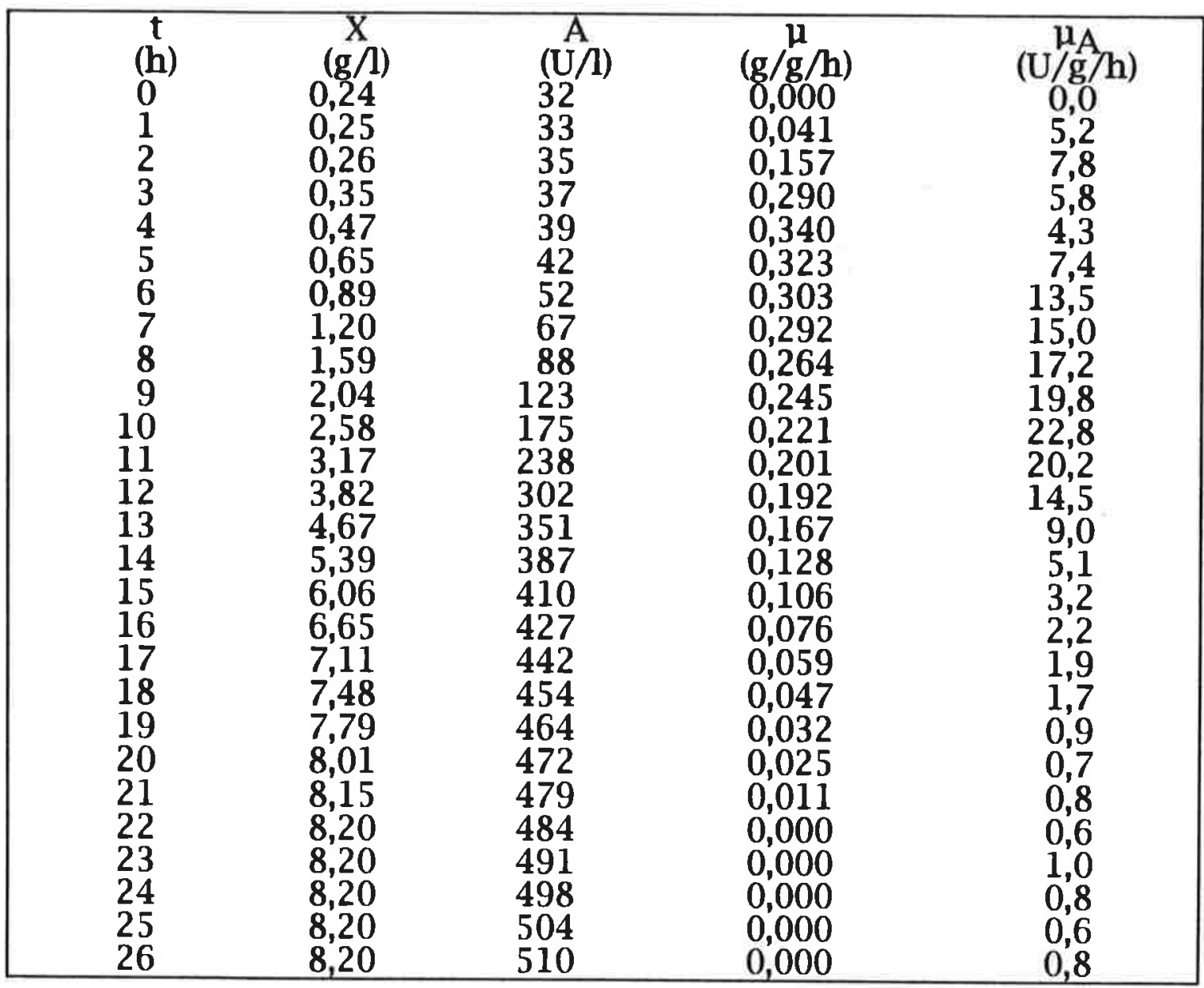


Tabela A.5 Concentração de ART (S), de glicose (G), de células (X) e atividade enzimática (A) em função do tempo para o ensaio B23 ( $3^{\circ}$ batch, 20g/ $)$

\begin{tabular}{|ccccc|}
\hline $\begin{array}{c}\text { tempo } \\
(\mathrm{h})\end{array}$ & $\begin{array}{c}\mathrm{S} \\
(\mathrm{g} / \mathrm{A})\end{array}$ & $\begin{array}{c}\mathrm{G} \\
(\mathrm{g} / \mathrm{l})\end{array}$ & $\begin{array}{c}\mathrm{X} \\
(\mathrm{g} / \mathrm{A})\end{array}$ & $\begin{array}{c}\mathrm{A} \\
(\mathrm{U} / \mathrm{A})\end{array}$ \\
2 & 20,7 & 3,8 & 34 & 38 \\
4 & 23,0 & 9,9 & 0,48 & 41 \\
6 & 19,8 & 13,7 & 0,56 & 53 \\
8 & 18,2 & 16,7 & 1,11 & 88 \\
10 & 18,2 & 17,1 & 1,54 & 163 \\
12 & 15,9 & 16,0 & 2,68 & 219 \\
14 & 14,5 & 14,1 & 3,25 & 268 \\
16 & 11,9 & 11,7 & 4,48 & 337 \\
18 & 8,5 & 8,7 & 5,24 & 396 \\
20 & 5,6 & 5,3 & & 468 \\
22 & 2,7 & 1,8 & & 535 \\
24 & 0,8 & 0,1 & & 541 \\
26 & 0,1 & 0,1 & 8,98 & 602 \\
28 & 0,2 & 0,1 & & 599 \\
\hline
\end{tabular}


Tabela A.6 Valores de concentração celular $(X)$ e atividade enzimática (A) considerados para o cálculo das velocidades específicas de crescimento $(\mu)$ e produção de enzima $\left(\mu_{A}\right)$ em função do tempo para o ensaio B23 ( $3^{\circ}$ batch, $\left.20 \mathrm{~g} / \mathrm{l}\right)$

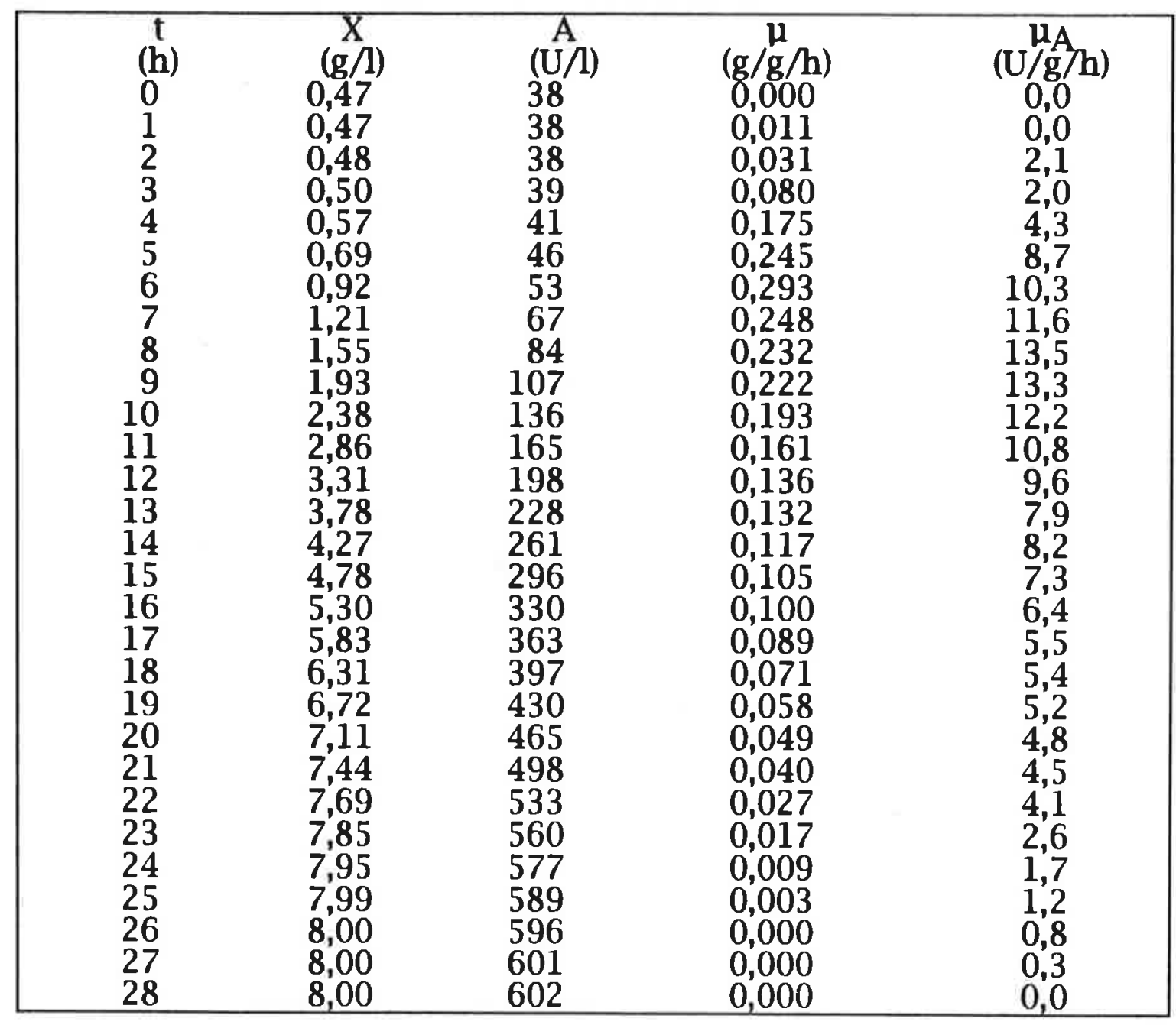


Tabela A.7 Concentração de ART (S), de glicose (G) de células (X) e atividade enzimática $(A)$ em função do tempo para o

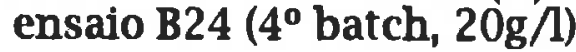

\begin{tabular}{|ccccc|}
\hline $\begin{array}{c}\text { tempo } \\
(\mathrm{h})\end{array}$ & $\begin{array}{c}\mathrm{S} \\
(\mathrm{g} / \mathrm{h})\end{array}$ & $\begin{array}{c}\mathrm{G} \\
(\mathrm{g} / \mathrm{A})\end{array}$ & $\begin{array}{c}\mathrm{X} \\
(\mathrm{g} / \mathrm{A})\end{array}$ & $\begin{array}{c}\mathrm{A} \\
(\mathrm{U} / \mathrm{A})\end{array}$ \\
0 & 21,5 & 2,1 & 0,30 & 18 \\
4 & 20,8 & 9,7 & 0,50 & 21 \\
8 & 18,3 & 14,8 & 1,50 & 63 \\
12 & 14,1 & 12,8 & 3,63 & 207 \\
16 & 6,8 & 6,1 & 6,08 & 321 \\
18 & 2,7 & 2,2 & 7,82 & 363 \\
20 & 0,3 & 0,2 & 8,36 & 414 \\
22 & 0,2 & 0,0 & 8,83 & 506 \\
24 & & 0,0 & 9,59 & 506 \\
26 & 0,3 & 0,0 & 8,80 & 506 \\
\hline
\end{tabular}


Tabela A.8 Valores de concentração celular $(\mathrm{X})$ e atividade enzimática (A) considerados para o cálculo das velocidades específicas de crescimento $(\mu)$ e produção de enzima $\left(\mu_{A}\right)$ em função do tempo para o ensaio B24 ( $4^{\circ}$ batch, $\left.20 \mathrm{~g} / \mathrm{A}\right)$

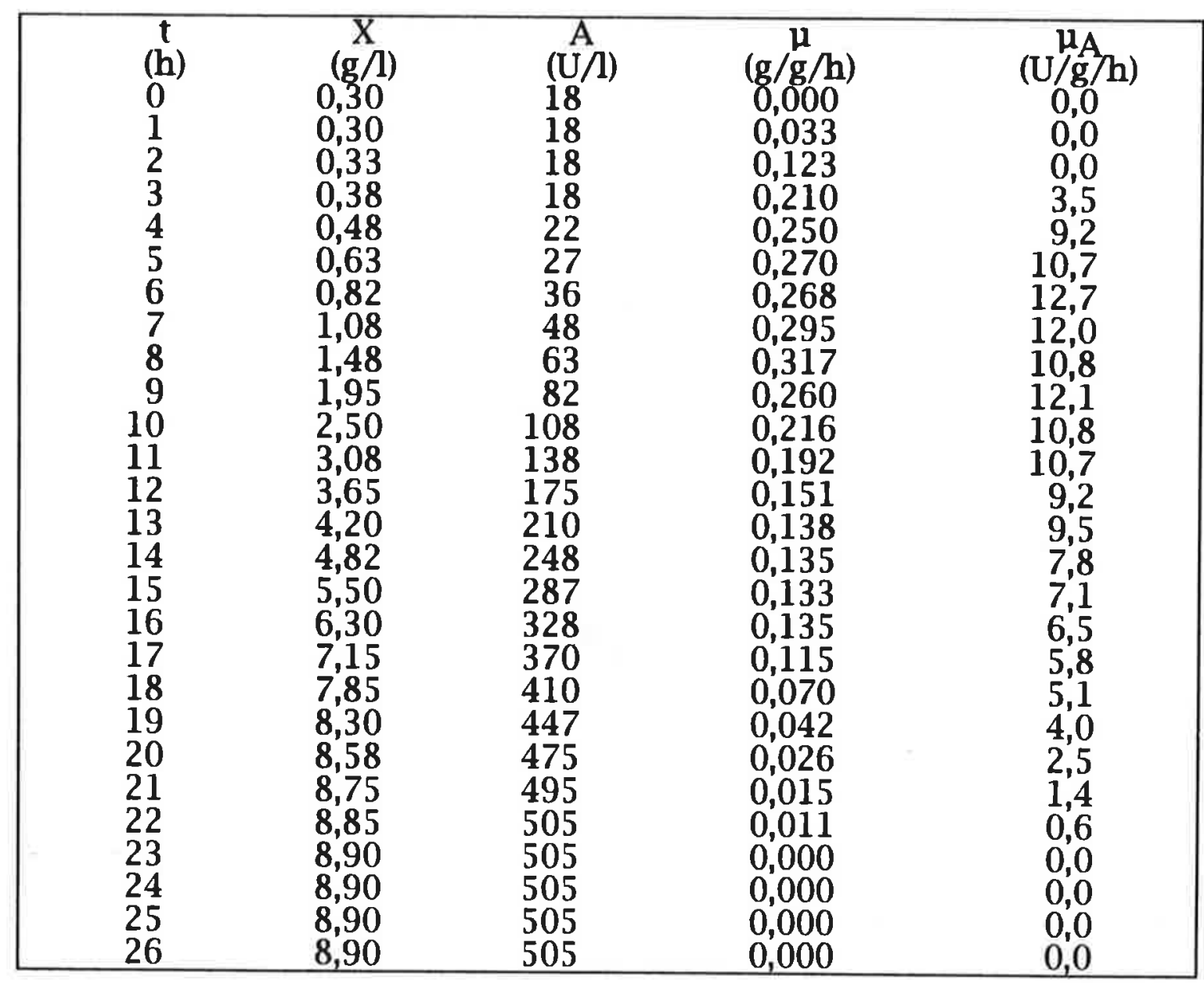


Tabela A.9 Concentração de ART (S), de glicose (G) de células (X) e atividade enzimática (A) em função do tempo para o ensaio B41 ( ${ }^{\circ}$ batch, $\left.40 \mathrm{~g} / 1\right)$

\begin{tabular}{|ccccc|}
\hline $\begin{array}{c}\text { tempo } \\
(\mathrm{h})\end{array}$ & $\begin{array}{c}\mathrm{S} \\
(\mathrm{g} / \mathrm{l})\end{array}$ & $\begin{array}{c}\mathrm{G} \\
(\mathrm{g} / \mathrm{l})\end{array}$ & $\begin{array}{c}\mathrm{X} \\
(\mathrm{g} / \mathrm{l})\end{array}$ & $\begin{array}{c}\mathrm{A} \\
(\mathrm{U} / \mathrm{M})\end{array}$ \\
3 & 44,7 & 2,9 & 0,29 & 20 \\
6 & 43,5 & 12,6 & 0,40 & 12 \\
6 & 42,4 & 19,9 & 0,83 & 29 \\
9 & 35,9 & 26,8 & 1,94 & 89 \\
12 & 29,5 & 28,6 & 3,72 & 305 \\
15 & 23,8 & 22,4 & 7,12 & 677 \\
18 & 16,7 & 16,1 & 8,74 & 1044 \\
21 & 8,2 & 7,8 & 11,12 & 1500 \\
24 & 0,6 & 0,3 & 12,27 & \\
27 & 0,3 & 0,1 & 12,13 & 2134 \\
30 & 0,1 & 0,0 & 12,15 & \\
33 & 0,2 & 0,0 & 12,65 & 2111 \\
36 & 0,2 & 0,0 & 12,20 & 2084 \\
\hline
\end{tabular}


Tabela A.10 Valores de concentração celular (X) e atividade enzimática (A) considerados para o cálculo das velocidades específicas de crescimento $(\mu)$ e produção de enzima $\left(\mu_{A}\right)$ em função do tempo para o ensaio B41 ( $1^{\circ}$ batch, $40 \mathrm{~g} /$ )

\begin{tabular}{|ccccc|}
\hline $\begin{array}{c}\mathrm{t} \\
(\mathrm{h})\end{array}$ & $\begin{array}{c}\mathrm{X} \\
(\mathrm{g} / \mathrm{h})\end{array}$ & $\begin{array}{c}\mathrm{A} \\
(\mathrm{U} / \mathrm{l})\end{array}$ & $\begin{array}{c}\mu \\
(\mathrm{g} / \mathrm{g} / \mathrm{h})\end{array}$ & $\begin{array}{c}\mu_{\mathrm{A}} \\
(\mathrm{U} / \mathrm{g} / \mathrm{h})\end{array}$ \\
0 & 0,32 & 21 & 0,000 & 0,0 \\
2 & 0,37 & 22 & 0,135 & 2,7 \\
4 & 0,51 & 25 & 0,216 & 4,8 \\
6 & 0,80 & 33 & 0,261 & 6,1 \\
8 & 1,43 & 63 & 0,305 & 14,8 \\
10 & 2,50 & 140 & 0,250 & 22,2 \\
12 & 3,90 & 310 & 0,203 & 27,9 \\
14 & 5,85 & 560 & 0,171 & 22,6 \\
16 & 7,75 & 820 & 0,112 & 18,8 \\
18 & 9,20 & 1100 & 0,071 & 14,0 \\
20 & 10,45 & 1360 & 0,052 & 11,5 \\
22 & 11,40 & 1600 & 0,030 & 10,0 \\
24 & 11,90 & 1790 & 0,020 & 6,7 \\
26 & 12,30 & 1950 & 0,011 & 5,1 \\
28 & 12,45 & 2060 & 0,004 & 3,3 \\
30 & 12,55 & 2110 & 0,002 & 0,9 \\
32 & 12,55 & 2120 & 0,000 & 0,0 \\
34 & 12,55 & 2120 & 0,000 & 0,0 \\
36 & 12,55 & 2120 & 0,000 & 0,0 \\
\hline
\end{tabular}


Tabela A.11 Concentração de ART (S), de glicose (G), de células (X) e atividade enzimática $(A)$ em função do tempo para o ensaio B42 $\left(2^{\circ}\right.$ batch, $\left.40 \mathrm{~g} / \mathrm{l}\right)$

\begin{tabular}{|ccccc|}
\hline $\begin{array}{c}\text { tempo } \\
(\mathrm{h})\end{array}$ & $\begin{array}{c}\mathrm{S} \\
(\mathrm{g} / \mathrm{l})\end{array}$ & $\begin{array}{c}\mathrm{G} \\
(\mathrm{g} / \mathrm{l})\end{array}$ & $\begin{array}{c}\mathrm{X} \\
(\mathrm{g} / \mathrm{l})\end{array}$ & \multicolumn{1}{c}{$\begin{array}{c}\mathrm{A} \\
(\mathrm{U} / \mathrm{M})\end{array}$} \\
0 & 42,3 & 3,4 & 0,27 & 5 \\
3 & 41,2 & 9,5 & 0,57 & 3 \\
6 & 38,5 & 16,3 & 1,20 & 155 \\
9 & 32,5 & 26,4 & 2,87 & 425 \\
12 & 26,2 & 24,9 & 5,05 & 660 \\
15 & 20,3 & 19,8 & 7,47 & 1943 \\
18 & 13,2 & 14,3 & 9,20 & 1579 \\
21 & 8,5 & 8,1 & 10,21 & 1794 \\
24 & 2,6 & 1,2 & 11,40 & 1928 \\
27 & 0,2 & 0,1 & 11,38 & 2087 \\
30 & 0,2 & 0,0 & 12,20 & 2042 \\
33 & 0,2 & 0,0 & 13,08 & 2006 \\
36 & 0,2 & 0,0 & 13,40 & \\
\hline
\end{tabular}


Tabela A.12 Valores de concentração celular (X) e atividade enzimática (A) considerados para o cálculo das velocidades específicas de crescimento $(\mu)$ e produção de enzima $\left(\mu_{A}\right)$ em função do tempo para o ensaio B42 ( $2^{\circ}$ batch, $40 \mathrm{~g} /$ )

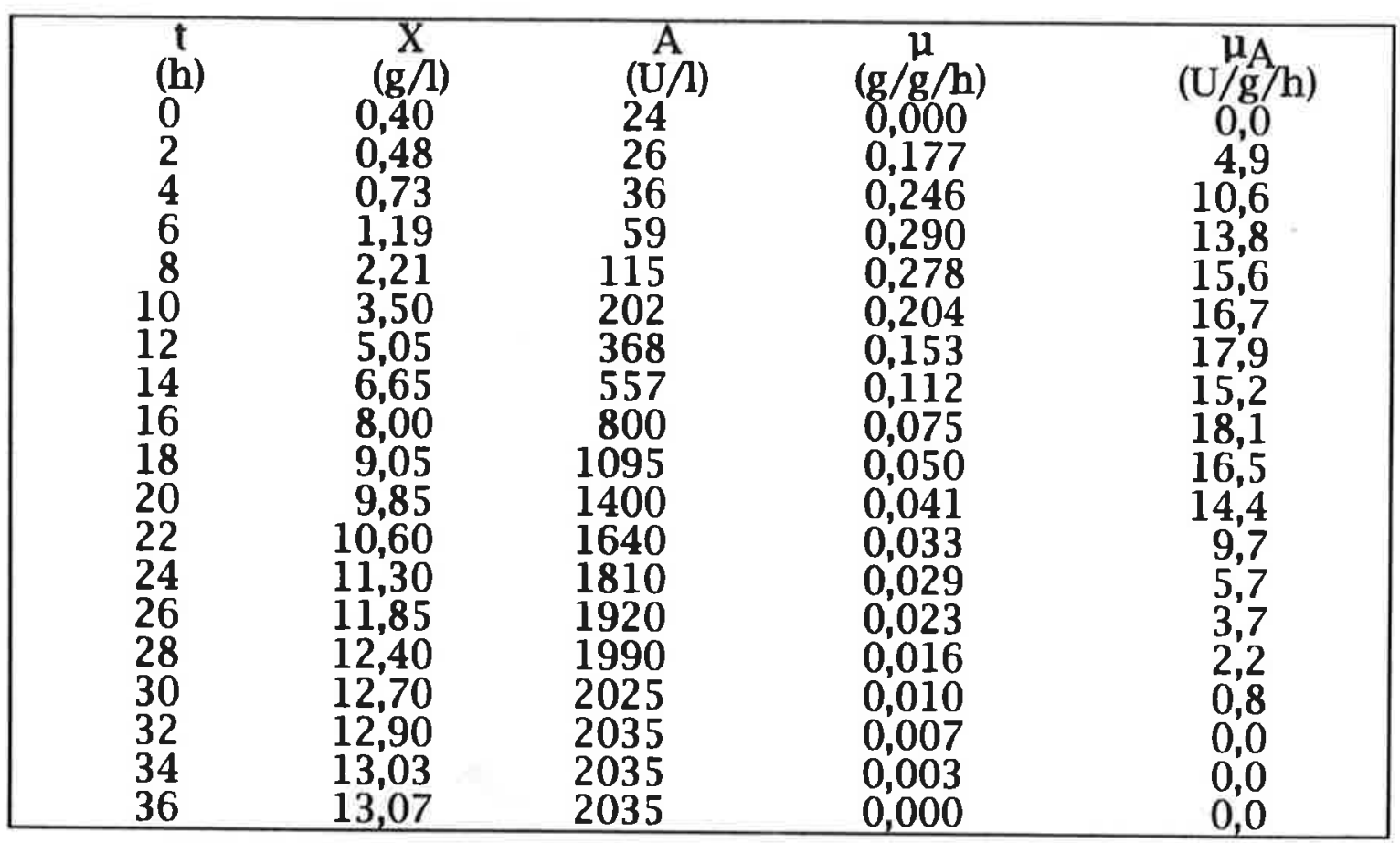


Tabela A.13 Concentração de ART (S), de glicose (G), de células (X) e atividade enzimática $(A)$ em função do tempo para o ensaio F21 (fed-batch, 20g/1, fs=13,3gART/h)

\begin{tabular}{|ccccc|}
\hline $\begin{array}{c}\text { tempo } \\
\text { (h) }\end{array}$ & $\begin{array}{c}\mathrm{S} \\
(\mathrm{g} / \mathrm{l})\end{array}$ & $\begin{array}{c}\mathrm{G} \\
(\mathrm{g} / \mathrm{l})\end{array}$ & $\begin{array}{c}\mathrm{X} \\
(\mathrm{g} / \mathrm{l})\end{array}$ & $\begin{array}{c}\mathrm{A} \\
(\mathrm{U} / \mathrm{M})\end{array}$ \\
0 & 4,2 & 3,1 & 0,23 & 36 \\
2 & 3,2 & 3,4 & 0,39 & 37 \\
4 & 2,7 & 3,2 & 0,52 & 45 \\
6 & 5,7 & 5,4 & 0,75 & 59 \\
8 & 7,2 & 7,0 & 1,45 & 86 \\
10 & 7,8 & 7,7 & 2,66 & \\
12 & 5,8 & 6,6 & 4,33 & 293 \\
14 & 3,2 & 3,2 & 7,11 & 505 \\
16 & 0,8 & 0,6 & 8,76 & 713 \\
18 & 0,2 & 0,2 & 8,26 & 940 \\
20 & 0,1 & 0,1 & 7,69 & 1080 \\
22 & 0,1 & 0,1 & 8,61 & 1111 \\
24 & 0,1 & 0,1 & 8,37 & 1129 \\
26 & 0,1 & 0,1 & 8,57 & 1155 \\
\hline
\end{tabular}


Tabela A.14 Valores de concentração celular (X) e atividade enzimática (A) considerados para o cálculo das velocidades específicas de crescimento ( $\mu)$ e produção de enzima $\left(\mu_{\mathrm{A}}\right)$ em função do tempo para o ensaio F21 (fed-batch, $20 \mathrm{~g} \lambda$, $\mathrm{fs}=13,3 \mathrm{gART} / \mathrm{h}$ )

\begin{tabular}{|ccccc|}
\hline $\begin{array}{c}\mathrm{t} \\
\text { (h) }\end{array}$ & $\begin{array}{c}\mathrm{X} \\
(\mathrm{g} / \mathrm{l})\end{array}$ & $\begin{array}{c}\mathrm{A} \\
(\mathrm{U} / \mathrm{l})\end{array}$ & $\begin{array}{c}\mathrm{\mu} \\
(\mathrm{g} / \mathrm{g} / \mathrm{h})\end{array}$ & $\begin{array}{c}\mu_{\mathrm{A}} \\
(\mathrm{U} / \mathrm{g} / \mathrm{h})\end{array}$ \\
0 & 0,36 & 36 & 0,000 & 0,0 \\
1 & 0,37 & 36 & 0,054 & 1,4 \\
2 & 0,39 & 37 & 0,077 & 3,3 \\
3 & 0,43 & 39 & 0,116 & 7,0 \\
4 & 0,49 & 44 & 0,163 & 9,4 \\
5 & 0,60 & 49 & 0,217 & 11,2 \\
6 & 0,78 & 57 & 0,269 & 11,8 \\
7 & 1,03 & 69 & 0,338 & 13,1 \\
8 & 1,47 & 86 & 0,333 & 13,7 \\
9 & 2,00 & 113 & 0,295 & 16,8 \\
10 & 2,65 & 156 & 0,281 & 18,1 \\
11 & 3,60 & 209 & 0,303 & 17,5 \\
12 & 4,82 & 293 & 0,231 & 19,7 \\
13 & 5,88 & 390 & 0,204 & 17,4 \\
14 & 7,15 & 498 & 0,166 & 15,3 \\
15 & 8,15 & 610 & 0,104 & 12,8 \\
16 & 8,80 & 715 & 0,045 & 12,5 \\
17 & 9,00 & 830 & 0,006 & 12,7 \\
18 & 9,00 & 940 & 0,000 & 11,0 \\
19 & 9,00 & 1025 & 0,000 & 7,6 \\
20 & 9,00 & 1080 & 0,000 & 2,8 \\
21 & 9,00 & 1095 & 0,000 & 1,2 \\
22 & 9,00 & 1105 & 0,000 & 1,2 \\
23 & 9,00 & 1120 & 0,000 & 1,4 \\
24 & 9,00 & 1130 & 0,000 & 1,2 \\
25 & 9,00 & 1140 & 0,000 & 1,2 \\
26 & 9,00 & 1145 & 0,000 & 0,0 \\
\hline
\end{tabular}


Tabela A.15 Concentração de ART (S), de glicose (G), de células (X) e atividade enzimática (A) em função do tempo para o ensaio F22 (fed-batch, 20g/1, fs=17, 1 gART/h)

\begin{tabular}{|ccccc|}
\hline $\begin{array}{c}\text { tempo } \\
(\mathrm{h})\end{array}$ & $\begin{array}{c}\mathrm{S} \\
(\mathrm{g} / \mathrm{l})\end{array}$ & $\begin{array}{c}\mathrm{G} \\
(\mathrm{g} / \mathrm{l})\end{array}$ & $\begin{array}{c}\mathrm{X} \\
(\mathrm{g} / \mathrm{l})\end{array}$ & $\begin{array}{c}\mathrm{A} \\
(\mathrm{U} / \mathrm{l})\end{array}$ \\
0 & 3,4 & 2,6 & 0,34 & 37 \\
2 & 3,0 & 3,2 & 0,42 & 42 \\
4 & 2,7 & 2,9 & 0,45 & 51 \\
6 & 5,3 & 5,0 & 0,88 & 78 \\
8 & 6,8 & 7,2 & 1,67 & 113 \\
10 & 6,9 & 7,8 & 2,79 & 187 \\
12 & 5,2 & 5,8 & 4,89 & 354 \\
14 & 2,5 & 4,8 & 6,87 & 609 \\
16 & 0,9 & 0,9 & 8,26 & 874 \\
18 & 0,2 & 0,1 & 8,79 & 1205 \\
20 & 0,1 & 0,1 & 8,42 & 1255 \\
22 & 0,2 & 0,1 & 8,01 & 1262 \\
24 & 0,2 & 0,1 & 7,38 & \\
26 & 0,0 & 0,1 & 7,07 & 1234 \\
\hline
\end{tabular}


Tabela A.16 Valores de concentração celular (X) e atividade enzimática (A) considerados para o cálculo das velocidades específicas de crescimento $(\mu)$ e produção de enzima $\left(\mu_{\mathrm{A}}\right)$ em função do tempo para o ensaio F22 (fed-batch, 20g $A$, fs $=17, \operatorname{lgART} / \mathrm{h}$ )

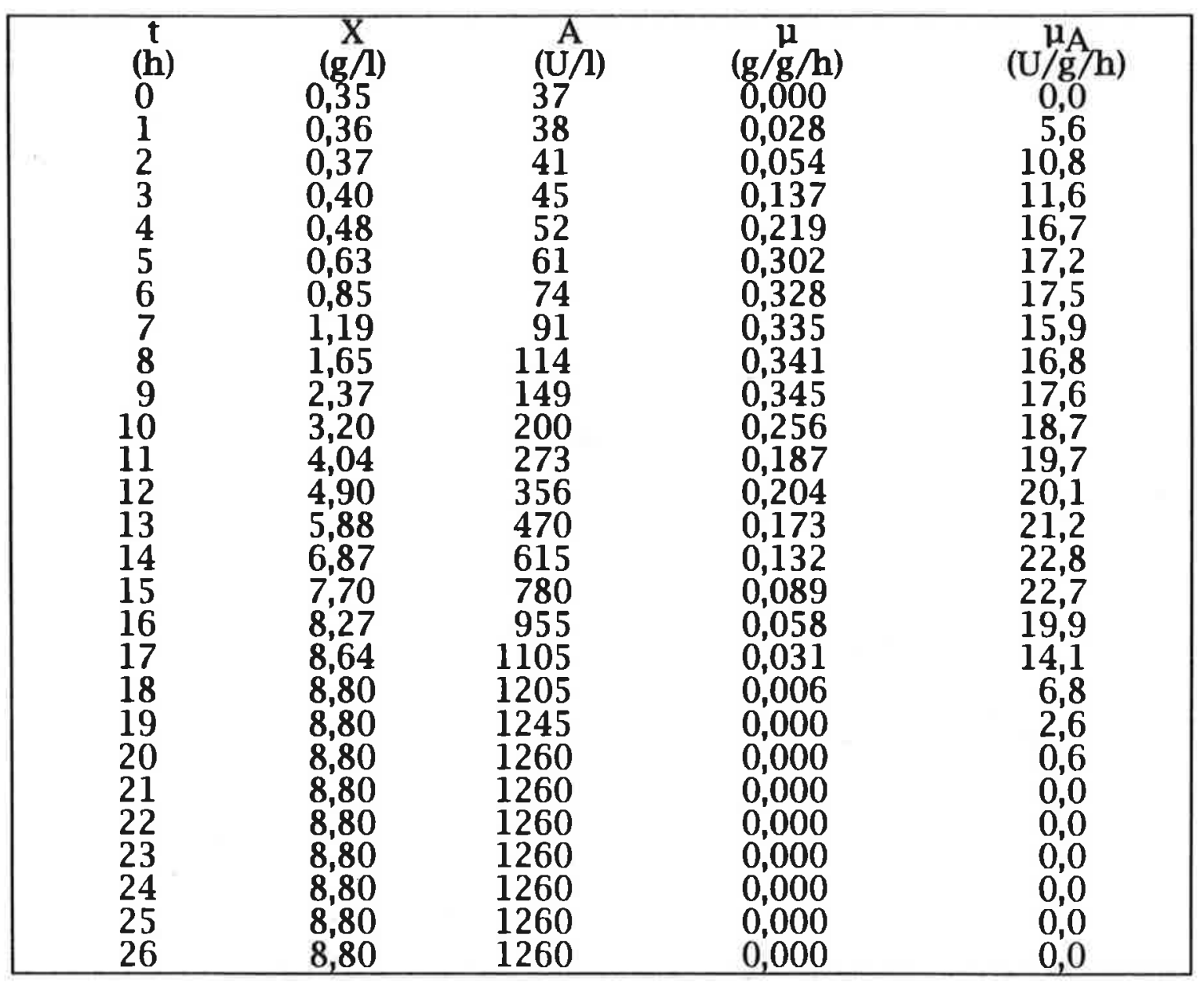


Tabela A.17 Concentração de ART (S), de glicose (G), de células (X) e atividade enzimática (A) em função do tempo para o ensaio F23 (fed-batch, 20g/1, fs=23,7gART/h)

\begin{tabular}{|ccccc|}
\hline $\begin{array}{c}\text { tempo } \\
(\mathrm{h})\end{array}$ & $\begin{array}{c}\mathrm{S} \\
(\mathrm{g} / \mathrm{l})\end{array}$ & $\begin{array}{c}\mathrm{G} \\
(\mathrm{g} / \mathrm{A})\end{array}$ & $\begin{array}{c}\mathrm{X} \\
(\mathrm{g} / \mathrm{1})\end{array}$ & $\begin{array}{c}\mathrm{A} \\
(\mathrm{U} / \mathrm{M})\end{array}$ \\
2 & 3,1 & 2,8 & 0,65 & 44 \\
4 & 3,0 & 3,0 & 0,50 & 28 \\
6 & 2,7 & 3,0 & 0,65 & 102 \\
8 & 6,9 & & 0,89 & 80 \\
10 & 9,6 & & 1,72 & 117 \\
12 & 11,8 & 9,5 & 2,95 & 181 \\
14 & 10,6 & & 4,82 & 322 \\
16 & 4,7 & 5,8 & 7,07 & 610 \\
18 & 0,3 & 0,2 & 8,70 & 925 \\
20 & 0,2 & 0,1 & 8,88 & 1182 \\
22 & 0,2 & 0,1 & 8,10 & 1219 \\
24 & 0,2 & 0,1 & 8,07 & 1240 \\
26 & 0,2 & 0,1 & 7,52 & 1219 \\
\hline
\end{tabular}


Tabela A.18 Valores de concentração celular (X) e atividade enzimática (A) considerados para o cálculo das velocidades específicas de crescimento $(\mu)$ e produção de enzima $\left(\mu_{A}\right)$ em função do tempo para o ensaio F23 (fed-batch, 20g 1 , fs $=23,7 \mathrm{gART} / \mathrm{h}$ )

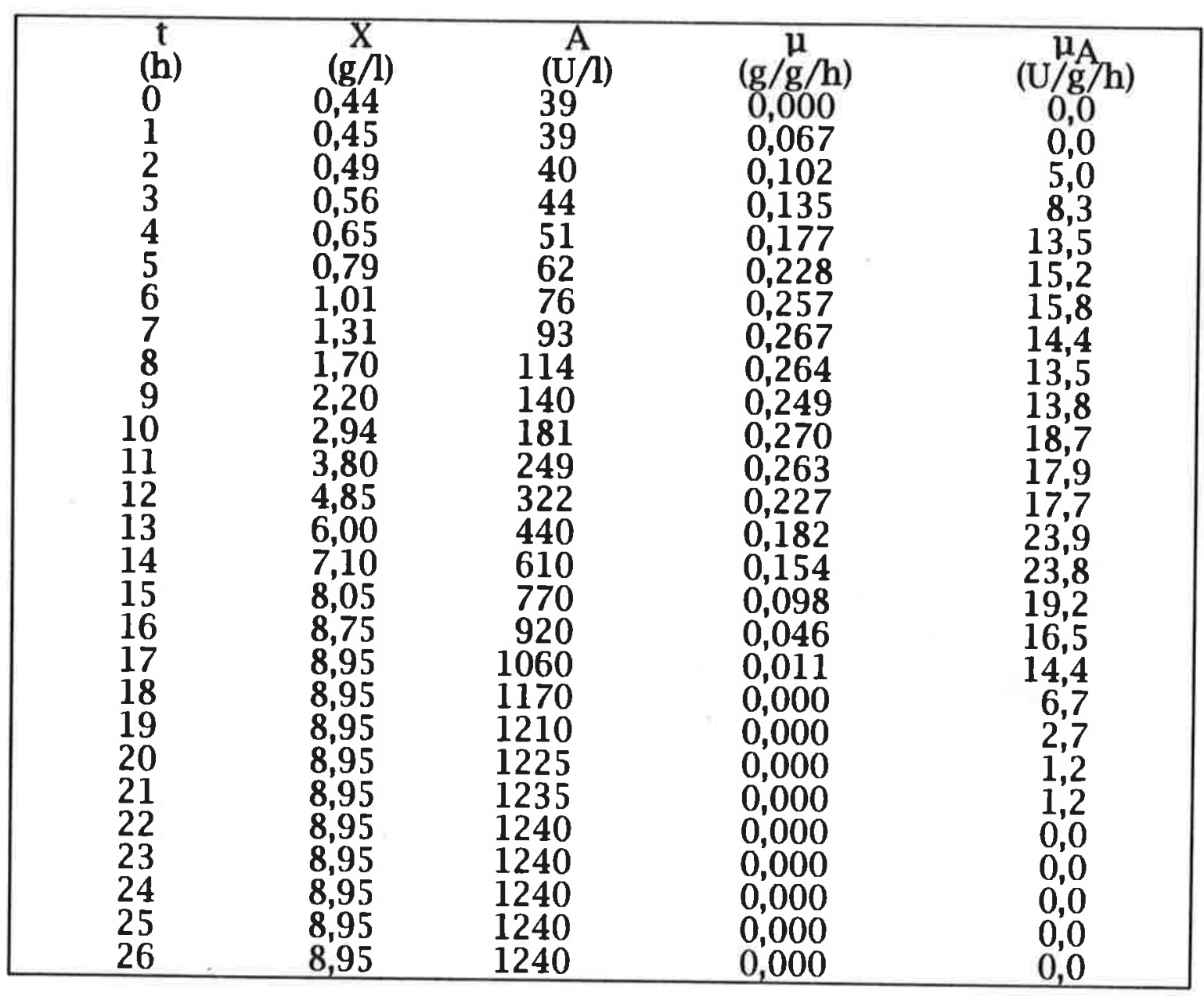


Tabela A.19 Concentração de ART (S), de glicose (G), de células (X) e atividade enzimática (A) em função do tempo para o ensaio F24 (fed-batch, 20g/1, fs=32,1gART/h)

\begin{tabular}{|ccccc|}
\hline $\begin{array}{c}\text { tempo } \\
(\mathrm{h})\end{array}$ & $\begin{array}{c}\mathrm{S} \\
(\mathrm{g} / \mathrm{l})\end{array}$ & $\begin{array}{c}\mathrm{G} \\
(\mathrm{g} / \mathrm{l})\end{array}$ & $\begin{array}{c}\mathrm{X} \\
(\mathrm{g} / \mathrm{l})\end{array}$ & $\begin{array}{c}\mathrm{A} \\
(\mathrm{U} / \mathrm{A})\end{array}$ \\
2 & & 3,0 & 0,34 & 34 \\
2 & 3,6 & 3,2 & 0,40 & 36 \\
4 & 3,2 & 3,9 & 0,48 & 39 \\
6 & 8,9 & 7,3 & 0,73 & 55 \\
8 & 13,5 & 13,1 & 1,41 & 71 \\
10 & 17,9 & 18,1 & 2,53 & \\
12 & 12,9 & 15,0 & 4,09 & 273 \\
14 & 8,5 & 9,5 & 6,48 & 458 \\
16 & 3,5 & 3,4 & 6,82 & 590 \\
18 & 0,1 & 0,1 & 8,89 & 761 \\
20 & 0,1 & 0,1 & 9,20 & 1057 \\
22 & 0,1 & 0,1 & 8,76 & 1043 \\
24 & 0,1 & 0,1 & 9,05 & 1039 \\
26 & 0,2 & 0,1 & 8,83 & 1046 \\
\hline
\end{tabular}


Tabela A.20 Valores de concentração celular (X) e atividade enzimática (A) considerados para o cálculo das velocidades específicas de crescimento $(\mu)$ e produção de enzima $\left(\mu_{A}\right)$ em função do tempo para o ensaio F24 (fed-batch, 20g $\lambda$, fs $=32, \lg$ ART $/ \mathrm{h}$ )

\begin{tabular}{|ccccc|}
\hline $\mathrm{t}$ & $\mathrm{X}$ & $\mathrm{A}$ & $\begin{array}{c}\mu \\
(\mathrm{g} / \mathrm{g} / \mathrm{h})\end{array}$ & $\begin{array}{c}\mu \mathrm{A} \\
(\mathrm{U} / \mathrm{g} / \mathrm{h})\end{array}$ \\
0 & 0,36 & 33 & 0,000 & 0,0 \\
1 & 0,36 & 33 & 0,028 & 2,8 \\
2 & 0,38 & 35 & 0,079 & 5,3 \\
3 & 0,42 & 37 & 0,107 & 5,8 \\
4 & 0,48 & 41 & 0,158 & $\mathbf{8 , 4}$ \\
5 & 0,57 & 46 & 0,195 & 11,9 \\
6 & 0,72 & 55 & 0,284 & 13,9 \\
7 & 0,99 & 66 & 0,338 & 13,0 \\
8 & 1,39 & 83 & 0,324 & 15,0 \\
9 & 1,91 & 107 & 0,309 & 14,9 \\
10 & 2,52 & 141 & 0,288 & 15,0 \\
11 & 3,35 & 187 & 0,247 & 17,1 \\
12 & 4,25 & 274 & 0,238 & 21,9 \\
13 & 5,40 & 360 & 0,213 & 16,5 \\
14 & 6,45 & 455 & 0,142 & 16,8 \\
15 & 7,27 & 570 & 0,103 & 15,1 \\
16 & 7,93 & 680 & 0,073 & 13,9 \\
17 & 8,40 & 800 & 0,053 & 14,8 \\
18 & $\mathbf{8}, 85$ & 915 & 0,039 & 11,8 \\
19 & 9,10 & 1005 & 0,016 & 7,4 \\
20 & 9,15 & 1050 & 0,000 & 1,3 \\
21 & 9,15 & 1055 & 0,000 & 0,0 \\
22 & 9,15 & 1055 & 0,000 & 0,0 \\
23 & 9,15 & 1055 & 0,000 & 0,0 \\
24 & 9,15 & 1055 & 0,000 & 0,0 \\
25 & 9,15 & 1055 & 0,000 & 0,0 \\
26 & 9,15 & 1055 & 0,000 & 0,0 \\
\hline
\end{tabular}


Tabela A.21 Concentração de glicose (G) de células $(X)$ e atividade enzimática (A) em função do tempo para o ensaio $\mathrm{F} 2 \mathrm{H}$ (fed-batch, 20g/l, fs=31,6gART/h, xarope hidrolisado)

\begin{tabular}{|ccccc|}
\hline $\begin{array}{c}\text { tempo } \\
(\mathrm{h})\end{array}$ & $\begin{array}{c}\mathrm{S} \\
(\mathrm{g} / \mathrm{l})\end{array}$ & $\begin{array}{c}\mathrm{G} \\
(\mathrm{g} / \mathrm{M})\end{array}$ & $\begin{array}{c}\mathrm{X} \\
(\mathrm{g} / \mathrm{M})\end{array}$ & $\begin{array}{c}\mathrm{A} \\
(\mathrm{U} / \mathrm{l})\end{array}$ \\
0 & -- & 3,1 & 0,47 & 36 \\
2 & -- & 2,9 & 0,49 & 39 \\
4 & -- & 5,0 & 0,67 & 46 \\
6 & -- & 8,9 & 1,19 & 68 \\
8 & -- & 15,1 & 2,13 & 90 \\
10 & -- & 16,2 & 3,41 & 144 \\
12 & -- & 12,1 & 5,85 & 282 \\
14 & -- & 7,2 & 7,67 & 509 \\
16 & -- & 2,8 & 9,45 & 719 \\
18 & -- & 0,1 & 10,11 & 986 \\
20 & -- & 0,1 & 9,54 & 1182 \\
22 & -- & 0,1 & 9,59 & 1219 \\
24 & -- & 0,1 & 10,69 & 1156 \\
26 & -- & 0,1 & 9,39 & 1197 \\
\hline
\end{tabular}


Tabela A.22 Valores de concentração celular (X) e atividade enzimática (A) considerados para o cálculo das velocidades específicas de crescimento $(\mu)$ e produção de enzima $\left(\mu_{A}\right)$ em função do tempo para o ensaio F2H (fed-batch, 20g 1 , $\mathrm{fs}=31,6 \mathrm{gART} / \mathrm{h}$, xarope hidrolisado)

\begin{tabular}{|ccccc|}
\hline $\begin{array}{c}\mathrm{t} \\
\text { (h) }\end{array}$ & $\begin{array}{c}\mathrm{X} \\
(\mathrm{g} / \mathrm{M})\end{array}$ & $\begin{array}{c}\mathrm{A} \\
(\mathrm{U} / \mathrm{h})\end{array}$ & $\begin{array}{c}\mu \\
(\mathrm{g} / \mathrm{g} / \mathrm{h})\end{array}$ & $\begin{array}{c}\mu_{\mathrm{A}} \\
(\mathrm{U} / \mathrm{g} / \mathrm{h})\end{array}$ \\
0 & 0,47 & 37 & 0,0 \\
1 & 0,48 & 38 & 0,000 & 4,2 \\
2 & 0,49 & 40 & 0,082 & 4,1 \\
3 & 0,56 & 43 & 0,161 & 7,1 \\
4 & 0,67 & 47 & 0,209 & 6,9 \\
5 & 0,85 & 54 & 0,281 & 9,4 \\
6 & 1,17 & 63 & 0,333 & 8,5 \\
7 & 1,61 & 74 & 0,286 & 8,6 \\
8 & 2,13 & 94 & 0,299 & 11,8 \\
9 & 2,85 & 129 & 0,286 & 14,2 \\
10 & 3,78 & 176 & 0,264 & $\mathbf{1 4}, 9$ \\
11 & 4,80 & 245 & 0,208 & $\mathbf{1 4 , 8}$ \\
12 & 5,80 & 320 & 0,172 & 14,3 \\
13 & 6,80 & 410 & 0,147 & 14,4 \\
14 & 7,75 & 505 & 0,116 & 11,3 \\
15 & 8,65 & 605 & 0,091 & 12,1 \\
16 & 9,35 & 720 & 0,069 & 13,3 \\
17 & 9,85 & 855 & 0,030 & 14,2 \\
18 & 10,00 & 990 & 0,005 & 12,5 \\
19 & 10,00 & 1105 & 0,000 & 9,0 \\
20 & 10,00 & 1175 & 0,000 & 4,7 \\
21 & 10,00 & 1210 & 0,000 & 2,4 \\
22 & 10,00 & 1220 & 0,000 & 0,0 \\
23 & 10,00 & 1220 & 0,000 & 0,0 \\
24 & 10,00 & 1220 & 0,000 & 0,0 \\
25 & 10,00 & 1220 & 0,000 & 0,0 \\
26 & 10,00 & 1220 & 0,000 & 0,0 \\
\hline
\end{tabular}


Tabela A.23 Concentração de ART (S), de glicose (G), de células (X) e atividade enzimática (A) em função do tempo para o ensaio F2I (fed-batch, 20g/, fs=31,6gART/h, alimentado desde início)

\begin{tabular}{|ccccc|}
\hline $\begin{array}{c}\text { tempo } \\
(\mathrm{h})\end{array}$ & $\begin{array}{c}\mathrm{S} \\
(\mathrm{g} / \mathrm{l})\end{array}$ & $\begin{array}{c}\mathrm{G} \\
(\mathrm{g} / \mathrm{M})\end{array}$ & $\begin{array}{c}\mathrm{X} \\
(\mathrm{g} / \mathrm{M})\end{array}$ & $\begin{array}{c}\mathrm{A} \\
(\mathrm{U} / \mathrm{M})\end{array}$ \\
0 & 7,8 & 3,0 & 0,52 & 38 \\
2 & 9,6 & 7,4 & 0,46 & 38 \\
4 & 13,6 & 11,4 & 0,60 & 38 \\
6 & 17,9 & 15,6 & 1,52 & 55 \\
8 & 15,9 & 14,1 & 2,64 & 100 \\
10 & 13,1 & 12,5 & 4,13 & 190 \\
12 & 9,8 & 9,5 & 4,77 & 278 \\
14 & 7,2 & 6,4 & 6,71 & 393 \\
16 & 2,8 & 2,7 & & 505 \\
18 & 0,4 & 0,1 & & 588 \\
20 & 0,2 & 0,1 & 9,13 & 752 \\
22 & 0,2 & 0,1 & & 758 \\
24 & 0,2 & 0,2 & 8,77 & 719 \\
26 & 0,3 & 0,2 & & 816 \\
\hline
\end{tabular}


Tabela A.24 Valores de concentração celular (X) e atividade enzimática (A) considerados para o cálculo das velocidades específicas de crescimento $(\mu)$ e produção de enzima $\left(\mu_{A}\right)$ em função do tempo para o ensaio F2I (fed-batch, 20g , fs $=31,6 \mathrm{gART} / \mathrm{h}$, alimentado desde início)

\begin{tabular}{|ccccc|}
\hline $\begin{array}{c}\mathrm{t} \\
(\mathrm{h})\end{array}$ & $\begin{array}{c}\mathrm{X} \\
(\mathrm{g} / \mathrm{h})\end{array}$ & $\begin{array}{c}\mathrm{A} \\
(\mathrm{U} / \mathrm{l})\end{array}$ & $\begin{array}{c}\mu \\
(\mathrm{g} / \mathrm{g} / \mathrm{h})\end{array}$ & $\begin{array}{c}\mu_{\mathrm{A}} \\
(\mathrm{U} / \mathrm{g} / \mathrm{h})\end{array}$ \\
0 & 0,44 & 38 & 0,000 & 0,0 \\
1 & 0,44 & 38 & 0,023 & 0,0 \\
2 & 0,47 & 38 & 0,106 & 1,1 \\
3 & 0,56 & 39 & 0,250 & 2,3 \\
4 & 0,75 & 42 & 0,333 & 5,3 \\
5 & 1,07 & 47 & 0,336 & 6,3 \\
6 & 1,48 & 56 & 0,311 & 7,9 \\
7 & 1,98 & 73 & 0,287 & 10,2 \\
8 & 2,63 & 100 & 0,225 & 12,1 \\
9 & 3,20 & 137 & 0,209 & 13,3 \\
10 & 3,90 & 185 & 0,179 & 12,0 \\
11 & 4,55 & 229 & 0,142 & 10,1 \\
12 & $\mathbf{5 , 3 0}$ & 277 & 0,141 & 10,0 \\
13 & 6,05 & 335 & 0,114 & 8,9 \\
14 & 6,75 & 390 & 0,111 & 8,8 \\
15 & 7,45 & 455 & 0,100 & 8,4 \\
16 & $\mathbf{8}, 15$ & 515 & 0,067 & 7,9 \\
17 & $\mathbf{8 , 6 5}$ & 585 & 0,045 & $\mathbf{8 , 6}$ \\
18 & 8,95 & 665 & 0,028 & 7,5 \\
19 & 9,10 & 720 & 0,005 & 4,8 \\
20 & 9,10 & 750 & 0,000 & 1,3 \\
21 & 9,10 & 760 & 0,000 & 0,5 \\
22 & 9,10 & 760 & 0,000 & 0,0 \\
23 & 9,10 & 760 & 0,000 & 0,0 \\
24 & 9,10 & 760 & 0,000 & 0,0 \\
25 & 9,10 & 760 & 0,000 & 0,0 \\
26 & 9,10 & 760 & 0,000 & 0,0 \\
\hline
\end{tabular}


Tabela A.25 Concentração de ART (S), de glicose (G), de células (X) e atividade enzimática (A) em função do tempo para o ensaio F41 (fed-batch, 40g/1, fs=14,5gART/h)

\begin{tabular}{|ccccc|}
\hline $\begin{array}{c}\text { tempo } \\
(\mathrm{h})\end{array}$ & $\begin{array}{c}\mathrm{S} \\
(\mathrm{g} / \mathrm{h})\end{array}$ & $\begin{array}{c}\mathrm{G} \\
(\mathrm{g} / \mathrm{l})\end{array}$ & $\begin{array}{c}\mathrm{X} \\
(\mathrm{g} / \mathrm{A})\end{array}$ & $\begin{array}{c}\mathrm{A} \\
(\mathrm{U} / \mathrm{M})\end{array}$ \\
3 & 3,4 & 2,3 & 0,17 & 20 \\
3 & 2,9 & 2,8 & 0,31 & 25 \\
6 & 4,6 & 4,1 & 0,77 & 42 \\
9 & 6,8 & 6,3 & 1,74 & 98 \\
12 & 5,9 & 5,6 & 3,44 & 266 \\
15 & 2,5 & 2,5 & 6,43 & 599 \\
18 & 0,7 & 0,8 & 8,56 & 1215 \\
21 & 0,1 & 0,1 & 10,18 & 1646 \\
24 & 0,1 & 0,1 & 11,03 & 2022 \\
27 & 0,7 & 0,6 & 11,26 & 2310 \\
30 & 0,2 & 0,1 & 11,34 & 2476 \\
33 & 0,1 & 0,1 & 11,58 & 2609 \\
36 & 0,2 & 0,1 & 10,91 & 2509 \\
\hline
\end{tabular}


Tabela A.26 Valores de concentração celular (X) e atividade enzimática (A) considerados para o cálculo das velocidades específicas de crescimento $(\mu)$ e produção de enzima $\left(\mu_{\mathcal{A}}\right)$ em função do tempo para o ensaio F41 (fed-batch, 40g/, fs $=14,5 \mathrm{gART} / \mathrm{h}$ )

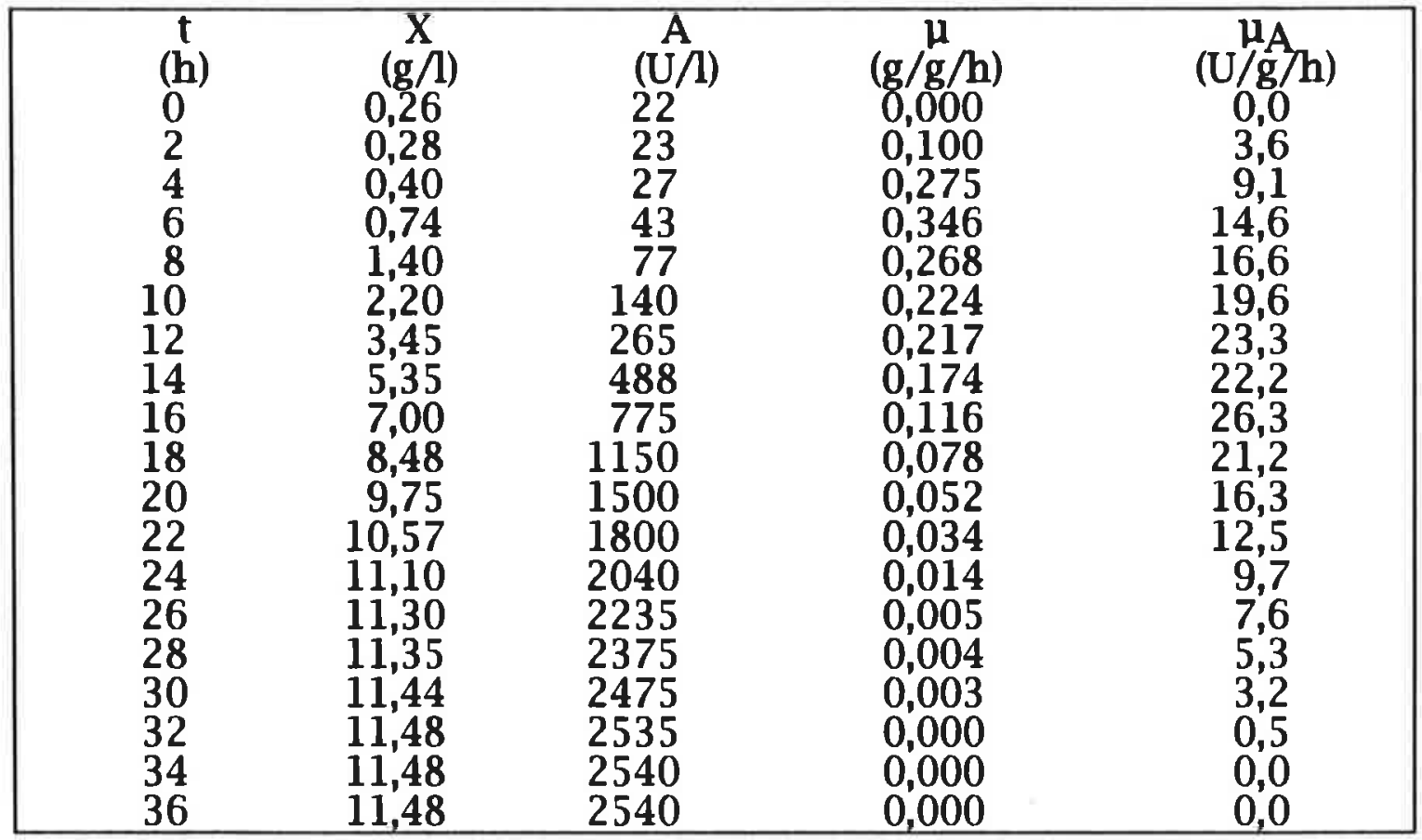


Tabela A.27 Concentração de ART (S), de glicose (G), de células (X) e atividade enzimática (A) em função do tempo para o ensaio F42 (fed-batch, 40g/, fs=20,8gART/h)

\begin{tabular}{|ccccc|}
\hline $\begin{array}{c}\text { tempo } \\
(\mathrm{h})\end{array}$ & $\begin{array}{c}\mathrm{S} \\
(\mathrm{g} / \mathrm{h})\end{array}$ & $\begin{array}{c}\mathrm{G} \\
(\mathrm{g} / \mathrm{l})\end{array}$ & $\begin{array}{c}\mathrm{X} \\
(\mathrm{g} / \mathrm{l})\end{array}$ & $\begin{array}{c}\mathrm{A} \\
(\mathrm{U} / \mathrm{M})\end{array}$ \\
0 & 2,9 & 2,1 & 0,20 & 20 \\
3 & 2,4 & 2,3 & 0,38 & 11 \\
6 & 5,0 & 4,4 & 1,03 & 19 \\
9 & 8,0 & 7,5 & 2,48 & 51 \\
12 & 7,0 & 7,2 & 5,15 & 394 \\
15 & 5,7 & 6,1 & 7,59 & \\
18 & 4,1 & 4,2 & 10,37 & 1165 \\
21 & 2,5 & 1,8 & 11,72 & 1627 \\
24 & 0,1 & 0,0 & 12,14 & 2206 \\
27 & 0,2 & 0,0 & 12,25 & 2338 \\
30 & 0,2 & 0,0 & 12,34 & 2377 \\
33 & 0,2 & 0,0 & 11,28 & 2338 \\
36 & 0,1 & 0,0 & 11,10 & 2285 \\
\hline
\end{tabular}


Tabela A.28 Valores de concentração celular (X) e atividade enzimática (A) considerados para o cálculo das velocidades específicas de crescimento $(\mu)$ e produção de enzima $\left(\mu_{A}\right)$ em função do tempo para o ensaio $\mathrm{F42}$ (fed-batch, $40 \mathrm{~g} \lambda$, $\mathrm{fs}=20,8 \mathrm{gART} / \mathrm{h}$ )

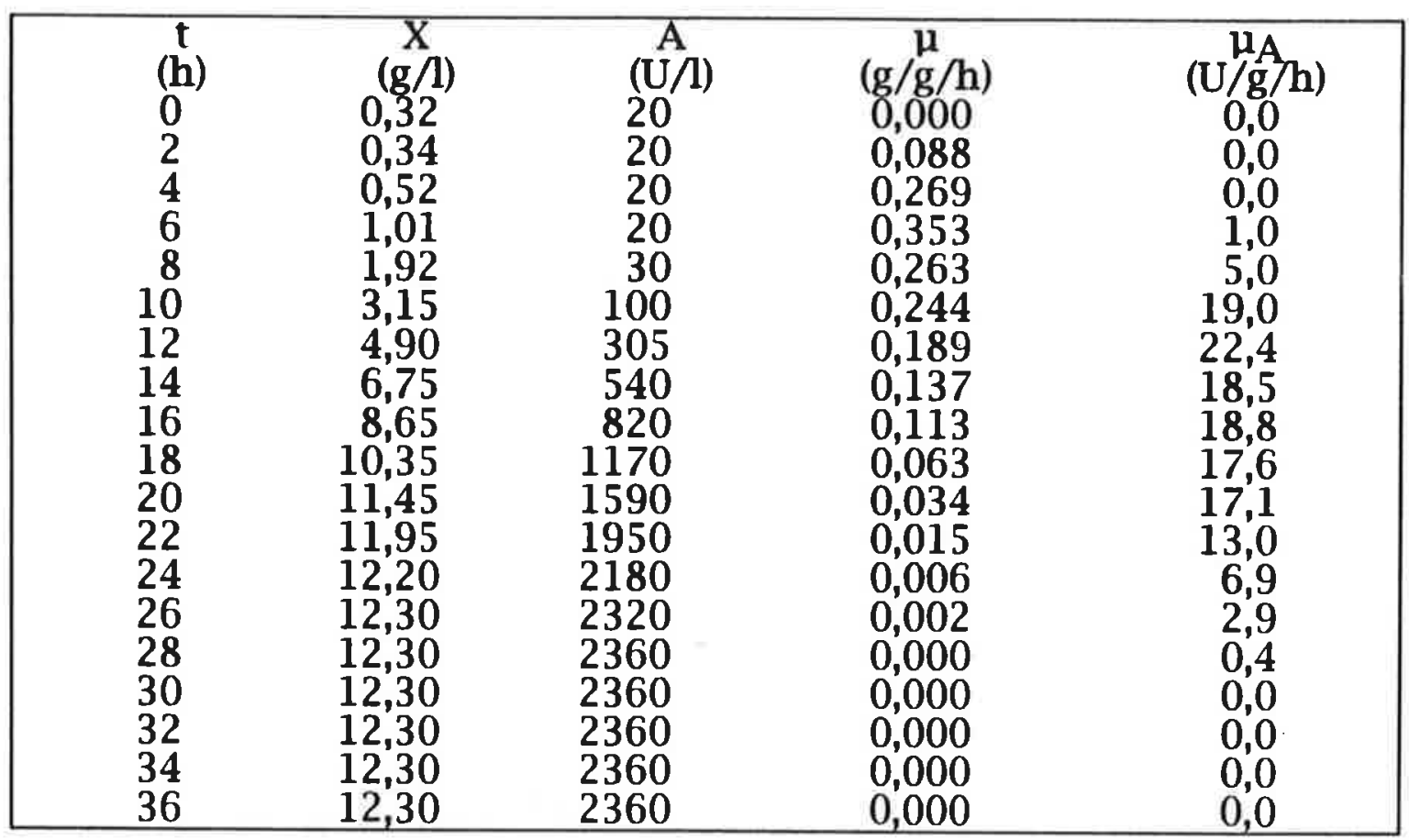


Tabela A.29 Concentração de ART (S), de glicose (G), de células (X) e atividade enzimática $(A)$ em função do tempo para 0 ensaio F43 (fed-batch, $40 \mathrm{~g} / \mathrm{h}$, $\mathrm{s}=32,2 \mathrm{gART} / \mathrm{h}$ )

\begin{tabular}{|ccccc|}
\hline $\begin{array}{c}\text { tempo } \\
(\mathrm{h})\end{array}$ & $\begin{array}{c}\mathrm{S} \\
(\mathrm{g} / \mathrm{)})\end{array}$ & $\begin{array}{c}\mathrm{G} \\
(\mathrm{g} / \mathrm{l})\end{array}$ & $\begin{array}{c}\mathrm{X} \\
(\mathrm{g} / \mathrm{l})\end{array}$ & $\begin{array}{c}\mathrm{A} \\
(\mathrm{U} / \mathrm{M}) \\
24\end{array}$ \\
3 & 2,2 & 2,2 & 0,33 & 29 \\
6 & 9,7 & 7,4 & 0,41 & 41 \\
9 & 17,6 & 14,6 & 0,68 & 65 \\
12 & 20,1 & 18,7 & 2,36 & 198 \\
15 & 21,0 & 19,6 & 6,93 & 533 \\
18 & 17,5 & 16,2 & 9,39 & 1076 \\
21 & 11,2 & 11,1 & 10,72 & 1801 \\
24 & 4,9 & 4,9 & 12,07 & 2295 \\
27 & 0,1 & 0,1 & 13,31 & 2987 \\
30 & 0,1 & 0,0 & 13,34 & \\
33 & 0,1 & 0,0 & 12,91 & 3160 \\
36 & 0,2 & 0,0 & 12,58 & 2974 \\
\hline
\end{tabular}


Tabela A.30 Valores de concentração celular (X) e atividade enzimática (A) considerados para o cálculo das velocidades específicas de crescimento $(\mu)$ e producão de enzima $\left(\mu_{A}\right)$ em função do tempo para o ensaio $\mathrm{F} 43$ (fed-batch, $40 \mathrm{~g} /$, fs $=32,2 \mathrm{gART} / \mathrm{h}$ )

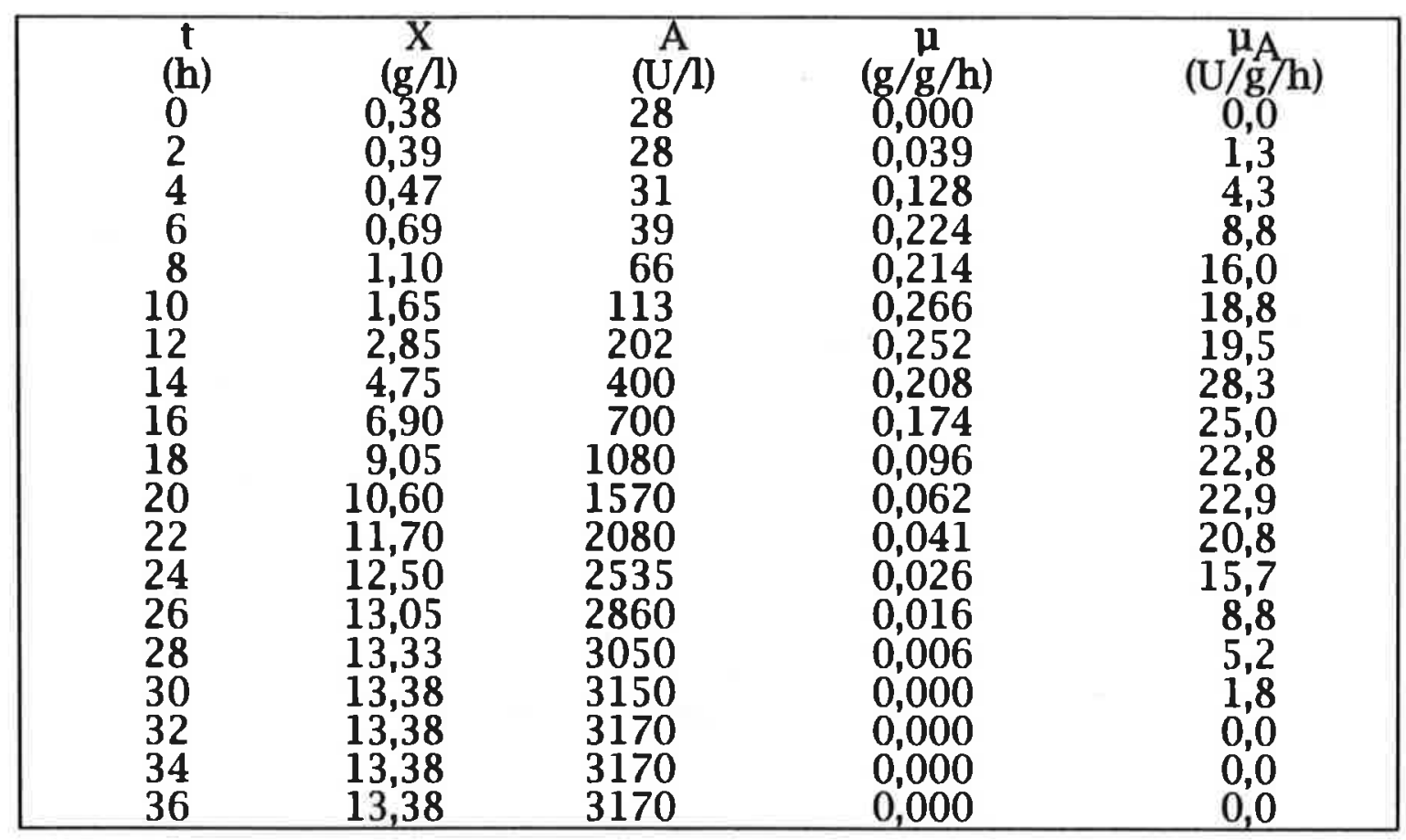


Tabela A.31 Concentração de glicose (G), de células (X) e atividade enzimática (A) em função do tempo para o ensaio $\mathrm{F} 4 \mathrm{H}$ (fed-batch, 40g/1, fs=21,1gART/h, xarope hidrolisado)

\begin{tabular}{|ccccc|}
\hline $\begin{array}{c}\text { tempo } \\
(\mathrm{h})\end{array}$ & $\begin{array}{c}\mathrm{S} \\
(\mathrm{g} / \mathrm{l})\end{array}$ & $\begin{array}{c}\mathrm{G} \\
(\mathrm{g} / \mathrm{A})\end{array}$ & $\begin{array}{c}\mathrm{X} \\
(\mathrm{g} / \mathrm{A})\end{array}$ & $\begin{array}{c}\mathrm{A} \\
(\mathrm{U} / 1)\end{array}$ \\
3 & -- & 2,0 & 0,29 & 14 \\
3 & -- & 2,3 & 0,55 & 14 \\
6 & -- & 5,6 & 1,00 & 122 \\
9 & -- & 8,7 & 2,46 & 360 \\
12 & -- & 9,3 & 5,05 & 751 \\
15 & -- & 8,8 & 8,02 & 1023 \\
18 & -- & 8,8 & 10,08 & 1547 \\
21 & -- & 9,4 & 11,13 & 2058 \\
24 & -- & 6,0 & 12,27 & 2487 \\
27 & -- & 0,5 & 12,67 & 2774 \\
30 & -- & 0,0 & 12,92 & 2813 \\
33 & -- & 0,0 & 14,27 & 2813 \\
36 & -- & 0,0 & 14,18 & \\
\hline
\end{tabular}


Tabela A.32 Valores de concentração celular (X) e atividade enzimática (A) considerados para o cálculo das velocidades específicas de crescimento $(\mu)$ e produção de enzima $\left(\mu_{A}\right)$ em função do tempo para o ensaio F4H (fed-batch, $40 \mathrm{~g} /$, fs $=21,1 \mathrm{gART} / \mathrm{h}$, xarope hidrolisado)

\begin{tabular}{|c|c|c|c|c|}
\hline $\begin{array}{c}\text { t } \\
(\mathrm{h}) \\
0 \\
2 \\
4 \\
6 \\
8 \\
10 \\
12 \\
14 \\
16 \\
18 \\
20 \\
22 \\
24 \\
26 \\
28 \\
30 \\
32 \\
34 \\
36\end{array}$ & $\begin{array}{c}X \\
(\mathrm{~g} / 1) \\
0,40 \\
0,44 \\
0,65 \\
1,05 \\
1,80 \\
3,20 \\
5,05 \\
7,05 \\
8,95 \\
10,10 \\
10,85 \\
11,40 \\
11,95 \\
12,45 \\
12,85 \\
12,95 \\
13,70 \\
14,15 \\
14,15\end{array}$ & $\begin{array}{c}\mathrm{A} \\
(\mathrm{U} / \mathrm{l}) \\
20 \\
21 \\
28 \\
52 \\
93 \\
160 \\
340 \\
580 \\
830 \\
1110 \\
1415 \\
1745 \\
2065 \\
2365 \\
2625 \\
2775 \\
2815 \\
2820 \\
2820\end{array}$ & $\begin{array}{c}\mu \\
(\mathrm{g} / \mathrm{g} / \mathrm{h}) \\
0,000 \\
0,148 \\
0,208 \\
0,248 \\
0,298 \\
0,258 \\
0,193 \\
0,145 \\
0,085 \\
0,044 \\
0,030 \\
0,024 \\
0,021 \\
0,018 \\
0,010 \\
0,011 \\
0,033 \\
0,002 \\
0,000\end{array}$ & $\begin{array}{c}\mu_{\mathrm{A}} \\
(\mathrm{U} / \mathrm{g} / \mathrm{h}) \\
0,0 \\
2,3 \\
11,0 \\
14,0 \\
14,1 \\
14,1 \\
22,9 \\
16,7 \\
15,4 \\
14,3 \\
14,7 \\
14,5 \\
12,8 \\
11,4 \\
8,2 \\
2,3 \\
0,4 \\
0,0 \\
0,0\end{array}$ \\
\hline
\end{tabular}




\section{A-2 REFERENCIAS BIBLIOGRÁFICAS}

AFSCHAR, A.S.; BELLGARDT, K.H.; BARTZKE, V.; NOTHNAGEL, J.; SCHAILER, K. EXPCON - a new approach for automatic control of the substrate flow rate in chemostat and fed-batch processes. Food-Biotechnol, 4(1):113-22, 1990.

AGUERO, J.M.Z. Influência do pH e da concentração inicial de substrato na sintese de amiloglicosidase por Aspergillus em cultivo submerso. São Paulo, 111p. Dissertação (Mestrado) - Escola Politécnica, Universidade de São Paulo, 1987.

AIBA, S.; HUMPHREY, A.E.; MIILIS, N.F. Biochemical Engineering, N.Y., Academic Press, $2^{2}$ ed., 434p., 1973.

ALAZARD, D.; RAIMBAULT, M. Comparative study of amylolytic enzymes production by Aspergillus niger in liquid and solid-state cultivation. Eur. J. Appl. Microbiol. Biotechnol., 12(2):113-7, 1981.

ALI, S.; HOSSAIN, Z.; MAHMOOD, S.; ALAM, R. Induction of glucoamylase production by non-starchy carbohydrates in Aspergillus terreus. World J. Microbiol Biotechnol., 6(1):19-22, 1990a.

ALI, S.; HOSSAIN, Z.; MAHMOOD, S.; ALAM, R. Purification of glucoamylase from Aspergillus terreus. World J. Microbiol. Biotechnol., 6(4):431-3, 1990b. 
ANANJIN, V.M.; KOMKOV, A.S.; SOLOVJEVA, I.V.; BOYEV, A.V.; OKUNEV, O.N. Some approaches to adaptive con japonicus. Acta Biotechnol, cellobiase producer
$11(2): 121-8,1991$.

ANDRZEJCZUK-HYBEL, J.; BARTOSZEWICZ, K.; KACZKOWSKI, J.; KUJAWSKI, M.; PILIER, K.; RYKAIA-ZIOBRO, M.; ZAJAC, A. KUJAWSKI, M.; PIIER, K.; RYKALA-ZIOBRO, NRR 3112 in the
Glucoamylase synthesis by Aspergillus awamori NRE
microtechnical scale. Acta Aliment. Pol, 4(4):381-90, 1978.

ARST, H.N.Jr.; BAIIEY, C.R. The regulation of carbon metabolism in Aspergillus nidulans. In: SMITH, J.; PATEMAN, J.A. Genetics and Physiology of Aspergillus. London, Academic Press, p.131-46, 1977.

ATTIA, R.M.; AII, S.A. Utilization of agricultural wastes by Aspergillus awamori for the production of glucoamylase. Rev. Microbiol., 5(4):814, 1974 .

AUNSTRUP, K. Production, isolation and economics of extracellular enzymes. In: WINGARD, L.B.Jr.; KATCHALSKI-KATZIR, E.; GOLDSTEIN,
L. Applied Biochemistry and Bioengineering, Enzyme Technology.
Nithe N.Y., Academic Press, v.2, p.27-69, 1979.

BAIIEY, J.E.; OLIS, D.F. Biochemical Engineering Fundamentals, N.Y.,

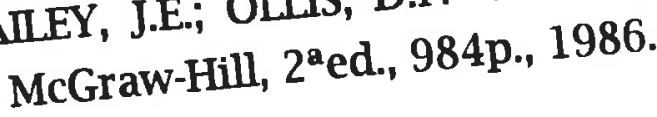

BARTON, L.L.; LINEBACK, D.R.; GEORGI, C.E. The influence of nitrogen and carbon sources on the production of glucoamylase by Aspergilli. J. Gen. Appl. Microbiol, 15(3):327-44, 1969.

BARTON, L.L.; GEORGI, C.E.; LINEBACK, D.R. Effect of maltose on glucoamylase formation by Aspergillus niger. J.Bacteriol, 111(3):7717, 1972. 
BATES, R.L; FONDY, P.L.; CORPSTEIN, R.R. An examination of some geometric parameters of impeller power. I \& EC Process Design and Development, 2(4):310-4, 1963.

BORZANI, W.; LIMA, U.A.; AQUARONE, E. Engenharia Bioquímica São Paulo, Edgard Blücher, v.3, 300p., série Biotecnologia, 1986.

BROCK, T.D. Regulation of protein synthesis: induction and repression. In: BROCK, T.D. Biology of microrganisms. N.Y., Prentice-Hall, $3^{\text {a }}$ d., p.289-96, 1979.

CHIQUETTO, M.L. Estudo comparativo entre diferentes fontes de carbono e de nitrogênio na síntese de amiloglicosidase por Aspergillus awamori NRRL 3112 em fermentação submersa. São Paulo, 177p. Dissertação (Mestrado) - Escola Politécnica, Universidade de São Paulo, 1990.

CRUEGER, W.; CRUEGER, A. Enzymes. In: Biotechnology: a textbook of industrial microbiology. Madison, Science Tech., p.161-86, 1984.

DAWSON, M.W.; MADDOX, I.S.; BOAG, I.F.; BROOKS, J.D. Application of fed-batch culture to citric acid production by Aspergillus niger: the effects of dilution rate and dissolved oxygen tension. Biotechnol. Bioeng., 32:220-6, 1988.

DI LUCCIO, R.C.; KIRWAN, D.J. Effect of dissolved oxygen on nitrogen fixation by $A$. vinelandii. I Free cells cultures. Biotechnol. and Bioeng., 26(1):81-6, 1984.

DOYLE, E.M.; KEILY, C.T.; FOGARTY, W.M. Production of the amylolytic enzymes of Penicillium expansum. Biochem. Soc. Trans., 19(3):270, 1991. 
ENSLEY, B.; MCHUGH, J.J.; BARTON, L.L. Effects of carbon sources on formation of alpha-amylase and glucoamylase by Clostridium acetobutylicum. J. Gen. Appl Microbiol, 21(1):51-9, 1975.

EVELEIGH, D.E. Elaboración microbiológica de productos químicos industriales. Investigacion y Ciencia, 62:95-104, Nov., 1981.

FACCIOTTI, M.C.R. Produção de amiloglicosidase por Aspergillus awamori NRRL 3112 em fermentação submersa - Estudo do processo semicontínuo e da influência da concentração inicial de polissacarídeo no processo descontínuo. São Paulo, 245p. Tese (Doutorado) - Escola Politécnica, Universidade de São Paulo, 1986.

FACCIOTTI, M.C.R.; WUHSTRACK, G.H.; TONSO, A.; CHIQUETTO, M.L; SCHMIDELL, W. Effect of yeast extract on glucoamylase synthesis by Aspergillus awamori NRRL 3112. Biotechnol. Letters, 13(8):547-52, 1991

FACHINI, E.R. Síntese de amiloglicosidase por Aspergillus awamori NRRL 3112 em cultura submersa: Influência das condições de transferência de oxigênio e da velocidade de respiração. São Paulo, 237p. Dissertação (Mestrado) - Escola Politécnica, Universidade de São Paulo, 1988.

FOGARTY, W.M. Microbial amylase. In: FOGARTY, W.M. Microbial Enzymes and Biotechnology, London, App. Sci. Publ. Ltd., p.2-56, 1983.

GADEN, E.L.Jr. Fermentation process kinetics. J. Biochem. Microbiol. Technol. Engineering, 1(4):413-29, 1959. 
GRACHEVA, I.M.; GAIDENKO, V.P.; SADOVA, A.I.; UVAROV, I.P. Effect of aeration on the biosynthesis of glucoamylase by Endomycopsis species 20-9. Prikl. Biokhim. Mikrobiol, 9(6):830-4, 1973.

GREENE, H.C.; FRED, E.B. Maintenance of vigorous mold stock cultures. Ind. Eng. Chem., 26:1297-9, 1934.

HAYASHIDA, S.; KUNISAKI, S.; NAKAO, M.; FLOR, P.Q. Evidence for raw starch-affinity site on Aspergillus awamori glucoamylase I. Agric. Biol. Chem., 46(1):83-9, 1982.

HOLLAND, B.; MACKMAN, N.; NICAUD, J.M. Secretion of proteins from bacteria. Biotechnology, 4(5):427-31, 1986.

IPT - INSTTTUTO DE PESQUISAS TECNOLÓGICAS DO ESTADO DE SÃO PAULO Estudo técnico-econômico de avaliação de oportunidades em enzimologia. São Paulo, 1987. (Relatório Técnico Final $n^{0}$ 24.403-1/87, $\mathrm{DQEQ} / \mathrm{AB} / \mathrm{IPT}$ )

IPT - INSTITUTO DE PESQUISAS TECNOLÓGICAS DO ESTADO DE SÃO PAULO Desenvolvimento de Tecnologia para Automação e Controle de Processos Fermentativos. Projeto apresentado a FINEP (Financiadora de Estudos e Projetos) e PADCT (Programa de Apoio ao Desenvolvimento Científico e Tecnológico), convênio $\mathbf{n}^{\mathbf{0}}$ 4.3.89.0498.00, coordenado por Prof. Dr. Antonio M.F.L.J. Bonomi, São Paulo, Agosto de 1990. (Relatório Técnico Parcial $\mathbf{n}^{\mathbf{0}}$ 28.228, $\mathrm{DQ} / \mathrm{AB} / \mathrm{IPT})$

JACOB, F.; MONOD, J. Genetic regulatory mechanisms in the synthesis of protein. J. Mol. Biol., 3:318-56, 1961. 
KIIIKIAN, B.V. Contribuição ao estudo do processo descontínuo e descontínuo alimentado na síntese de amiloglicosidase por Aspergillus awamori NRRL 3112. São Paulo, 247p. Tese (Doutorado) Escola Politécnica, Universidade de São Paulo, 1989.

KOBAYASH, T.; NAGAMUNE, T.; ENDO, I. An effective production method of glucoamylase in a novel solid-state culture system. Ann. N. Y. Acad. Sci, 613:846-55, 1990.

KUEK, C. Production of glucoamylase using Aspergillus phoenicus immobilized in calcium alginate beads. Appl. Microbiol. Biotechnol, 35(4):466-70, 1991.

KULP, K. Carbohydrases. In: REED, G. Enzymes in food processing. N.Y., Academic Press, 2a ed., p.53-122, 1975.

KVESITADZE, G.I.; VORONTSOVA, N.N.; GONCHAROVA, O.N.; KORIDZE, V.V.; DVADTSATOVA, E.A.; KVACHADZE, L.L. Exogenous glucoamylase from molds of the genus Aspergillus. Appl. Biochem. Microbiol, 17(4):427-31, 1981.

LE DUY, A.; ZAJIC, J.E. A geometrical approach for differentation of a experiment function at a point applied to growth and product formation. Biotechnol. Bioeng., 15(4):805-10, 1973.

LELONG, P.; CELLARD, H.; PARDO, D.; CAVALIE, J.M. Automation of glucose measurement in fermentor broths. Appl. Microbiol. Biotechnol, 36(2):173-7, 1991. 
LESSMANN, W.F. Estudo do processo descontínuo alimentado para a produçào de amiloglicosidase por Aspergillus awamori NRRL 3112 para concentrações de polissacarídeo de 40 e $80 \mathrm{~g} /$. São Paulo, 131p. Dissertação (Mestrado) - Escola Politécnica, Universidade de São Paulo, 1993.

LINEBACK, D.R.; RUSSEIL, I.J.; RASMUSSEN, C. two forms of glucoamylase of Aspergillus niger. Arch. Biochem and Bioph, 134:539-53, 1969.

LINEBACK, D.R.; AIRA, L.A. Structural characterization of the two forms of glucoamylase from Aspergillus niger. Cereal Chem., 49(3):293-8, 1972.

MACEDO, G.R. Influência do pH e da temperatura na produção de amiloglicosidase por Aspergillus niger NRRL 337. São Paulo, 111p. Dissertação (Mestrado) - Escola Politécnica, Universidade de São Paulo, 1982.

MAGALHÃES, A.P. Enzimas: Situação de Mercado e Tendências. Revista Brasileira de Engenharia Química, (3):22-5, maio, 1989.

MANDEIS, M.; PARRISH, F.W.; REESE, E.T. Sophorose as an inducer of cellulase in Trichoderma viride. J. Bacteriol., 83:400-8, 1962.

MONOD, J. Recherches sur la croissance des cultures bacteriennes. Paris, Hermann \& Cie., 1942.

NEGRÃO, O.L.; FONTANA, J.D.; ZANCAN, J.T. Production of glucoamylase by Dactylium dendroides. Rev. Microbiol, 12(4):170-5, 1981. 
OLSVIK, E.S.; KRISTIANSEN, B. Influence of oxygen tension, biomass concentration, and specific growth rate on the rheological properties of a filamentous fermentation broth. Biotechnol Bioeng., 40(11):12939, 1992.

PARK, Y.K. Normalização dos métodos para determinação da atividade de algumas enzimas industriais. Instruções Técnicas ITAL, 2:1-15, 1969.

PARK, Y.K.; LIMA, D.C. Produção de amiloglicosidase fúngica por fermentação submersa e sua purificação. Rev. Bras. de Tecnol., 3:6773, 1972.

PARK, Y.K.; SANTI, M.S.S. Induction of high amyloglucosidaseproduction mutant from Aspergillus awamori. J. Ferm. Technol, 55(2):193-5, 1977.

PAZUR, J.H.; KNULL, H.R.; CEPURE, A. Glycoenzymes: Structure and properties of the two forms of glucoamylase from Aspergillus niger. Carbohydr. Res., 20(1):83-96, 1971.

PAZUR, J.H.; TOMINAGA, Y.; FORSBERG, L.S.; SIMPSON, D.L. Glycoenzymes: an unusual type of glycoprotein structure for a glucoamylase. Carbohydr. Res., 84(1):103-14, 1980.

PERSSON, I.; TJERNEID, F.; HAHN-HAGERDAL, B. Fungal cellulolytic enzyme production: a review. Process Biochem, 26(2):65-74, 1991.

PIRT, S.J. The theory of fed batch culture with reference to penicillin fermentation. J. Appl. Chem. Biotechnol, 24:415-24, 1974.

PIRT, S.J. Principles of microbe and cell cultivation. Oxford, Blackwell Scient., 274p., 1975. 
PRIEST, F.G. Enzyme synthesis: regulation and process of secretion by microrganisms. In: FOGARTY, W.M. Microbial Enzymes and Biotechnology, London, App. Sci. Publ. Ltd., p.319-68, 1983.

RAM, K.A.; VENKATASUBRAMANIAN, K. Enhancement of starch conversion efficiency with free and immobilized pullulanase and alpha-1,4-glucosidase. Biotechol Bioeng., 24(2):335-69, 1982.

RAMACHANDRAN, N.; SREEKANTIAH, K.R.; MURTHY, V.S. Influence of media composition on the production of alpha-amylase and amyloglucosidase by a strain of Aspergillus niger. Starch/Stärke, 31(4):134-8, 1979.

RAMAIEY, R.F. Molecular biology of extracellular enzyme. In: PERLMAN, D. Advances in Applied Microbiology., N.Y., Academic Press, v.25, p.37-55, 1979.

RAPER, K.B.; FENNELL, D.I. The Genus Aspergillus. Baltimore, Williams \& Wilkins, p.56-7, 1965.

REESE, E.T.; MAGUIRE, A. Surfactants as stimulants of enzyme production by microrganisms. Appl Microbiol, 17(2):242-5, 1969.

SCHAFHAUSER, D.Y.; STORY, K.B. Co-immobilization of amyloglucosidase and pullulanase on to granular chicken bone for enhanced starch degradation. Biotechnology and Applied Biochemistry, 17(1):103-13, 1993.

SCHMIDELL, W. Estudo do processo fermentativo contínuo de produção de amiloglicosidase por Aspergillus niger NRRL 337 - Comparação com o processo descontínuo. São Paulo, 216p. Tese (Livre-Docência) Escola Politécnica, Universidade de São Paulo, 1986. 
SCHMIIDELL, W.; FERNANDES, M.V. The measurement of cellular protein content as a method for determining mold concentration. J. Ferment. Technol, 54(4):2225-8, 1976.

SCHMIDELL, W.; FERNANDES, M.V. Comparação entre hidrólise ácida e enzimática de amido para determinação de açúcares redutores totais. Rev. Microbiol., 8(3):98-101, 1977.

SCHMIDELL, W.; MENEZES, J.R.G. Influência da glicose na determinação da atividade da amiloglicosidase. Rev. Microbiol, 17(3):194-200, 1986.

SCHMIDELL, W.; FACCIOTTI, M.C.R.; ABOUTBOUL, H.; KIIIKIAN, B.V. Comparação de linhagens produtivas de amiloglicosidase. In: XI Simpósio Anual da Academia de Ciências do Estado de São Paulo (ACIESP), Anais, São Paulo, 1986.

SCHMIDELL, W.; FACCIOTTI, M.C.R. Production of extracellular enzymes: amyloglucosidase. Int. Ind. Biotechnol, 7(6):370-4, 1987.

SCHMIDELL, W.; FACCIOTTI, M.C.R.; KIIIKIAN, B.V.; ABOUTBOUL, H. Development of glucoamylase synthesis studies in a Biochemical Engineering Laboratory. Int. Ind. Biotechnol., 9(1):15-7, 1989.

SEARLE, B.A.; TUBB, R.S. Regulation of amyloglucosidase production by Saccharomyces diastaticus. J. Inst. Brew., 87(4):244-7, 1981.

SHIANG, M.; LINDEN, J.C.; MOHAGHEGHI, A.; GROHMANN, K.; HIMMEL, M.E. Enhanced production of cellulase using Acidothermus cellulolyticus fed-batch culture. Appl Microbiol Biotechnol, 34(5):591-7, 1991. 
SHINMYO, A.; TAHARA, T.; MATSUMOTO, H.; TERUI, G. Kinetic studies on enzymes production by microbes (VIII). Autoinduction of acid protease in Aspergillus niger. J. Ferment. Technol, 49(6):535-43, 1971.

SHIOYA, S. Optimization and control in fed-batch bioreactors. Adv. Biochem. Eng./Biotechnol, 46:111-42, 1992.

SINKAR, V.P.; LEWIS, N.F. Glucoamylase production by a newly isolated strain of Aspergillus niger. J. Food Protection, 45(7):586-9, 1982.

SMIIEY, K.L.; CADMUS, M.C.; HENSLEY, D.E.; LAGODA, A.A. High-potency amyloglucosidase-producing mold of the Aspergillus niger group. Appl. Microbiol., 12(5):455, 1964.

SMIIEY, K.L.; HENSLEY, D.E.; SMIIEY, M.J.; GASDORF, H.J. Kinetics patterns of glucoamylase isolated from Aspergillus species. Arch. Biochem. Bioph., 144:694-9, 1971.

STANBURY, P.F.; WHITAKER, A. Principles of Fermentation Technology, Oxford, Pergamon Press, $1^{\text {aed., }}$ 255p., 1984.

WANG, D.I.C.; COONEY, C.L.; DEMAIN, A.L.; DUNNIL, P.; HUMPHREY, A.E.; LILLY, M.D. Fermentation and Enzyme Technology. N.Y., John Wiley, p.374, 1979

WASSERMAN, B.P. Thermostable enzyme production. Food Technol, 38(2):78-89, 1984.

WHITAKER, A. Fed-batch culture. Process Biochemistry, may:10-5, 1980. 
WITTLER, R.; SCHUGGERL, K. Interrelation between penicillin productivity and growth rate. Appl. Microbiol. Biotechnol., 21:348-55, 1985.

YAMANE, T.; KISHIMOTO, M.; YOSHIDA, F. Semi-batch culture of methanol assimilating bacteria with exponentially increased methanol feed. J. Ferm. Technol, 54(4):229-40, 1976.

YAMANE, T.; SHIMIZU, S. Fed-batch techniques in microbial process. In: GHOSE, T.K.; FIECHTER, A.; BLAKEBROUGH, Advances in Biochemical Engineering, Berlin, Springer-Verlag, vol.30, p.148-194, 1984.

YOKOYA, F.; VITALI, A.A. Repressão catabólica e a microbiologia industrial. Ciência e Cultura, 25(4):321-3, 1973.

YOSHIDA, F.; YAMANE, T.; NAKAMOTO, K.-I. Fed-batch hydrocarbon fermentation with colloidal emulsion feed. Biotechnol. Bioeng., 15:257-70, 1973.

ZENG, A.P.; BYUN, T.G.; DECKWER, W.D. On-line estimation of viable biomass of a microaerobic culture using exit gas analysis. Biotechnol. Tech, 5(4):247-50, 1991. 